\author{
UNIVERSIDADE DE SÃO PAULO \\ ESCOLA DE ENGENHARIA DE SÃO CARLOS \\ DEPARTAMENTO DE ENGENHARIA MECÂNICA
}

CARLOS EDUARDO GOMES DE CASTRO

Caracterização mecânica e análise de falha de juntas termoplásticas soldadas e termorrígidas coladas de laminados compósitos de grau aeronáutico

SÃO CARLOS 



\section{Caracterização mecânica e análise de falha de juntas termoplásticas soldadas e termorrígidas coladas de laminados compósitos de grau aeronáutico}

Dissertação apresentada a Escola de Engenharia de São Carlos, da Universidade de São Paulo, como parte dos requisitos para obtenção do título de Mestre em Engenharia Mecânica. Área de concentração: Materiais.

Orientador: Prof. Dr. José Ricardo Tarpani

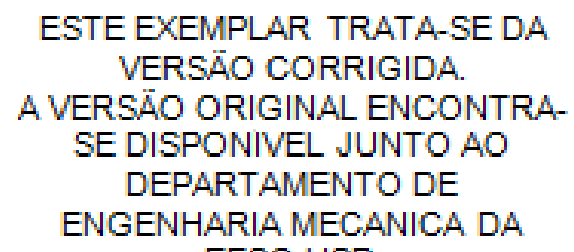

São Carlos 
AUTORIZO A REPRODUÇÃO TOTAL OU PARCIAL DESTE TRABALHO, POR QUALQUER MEIO CONVENCIONAL OU ELETRÔNICO, PARA FINS DE ESTUDO E PESQUISA, DESDE QUE CITADA A FONTE.

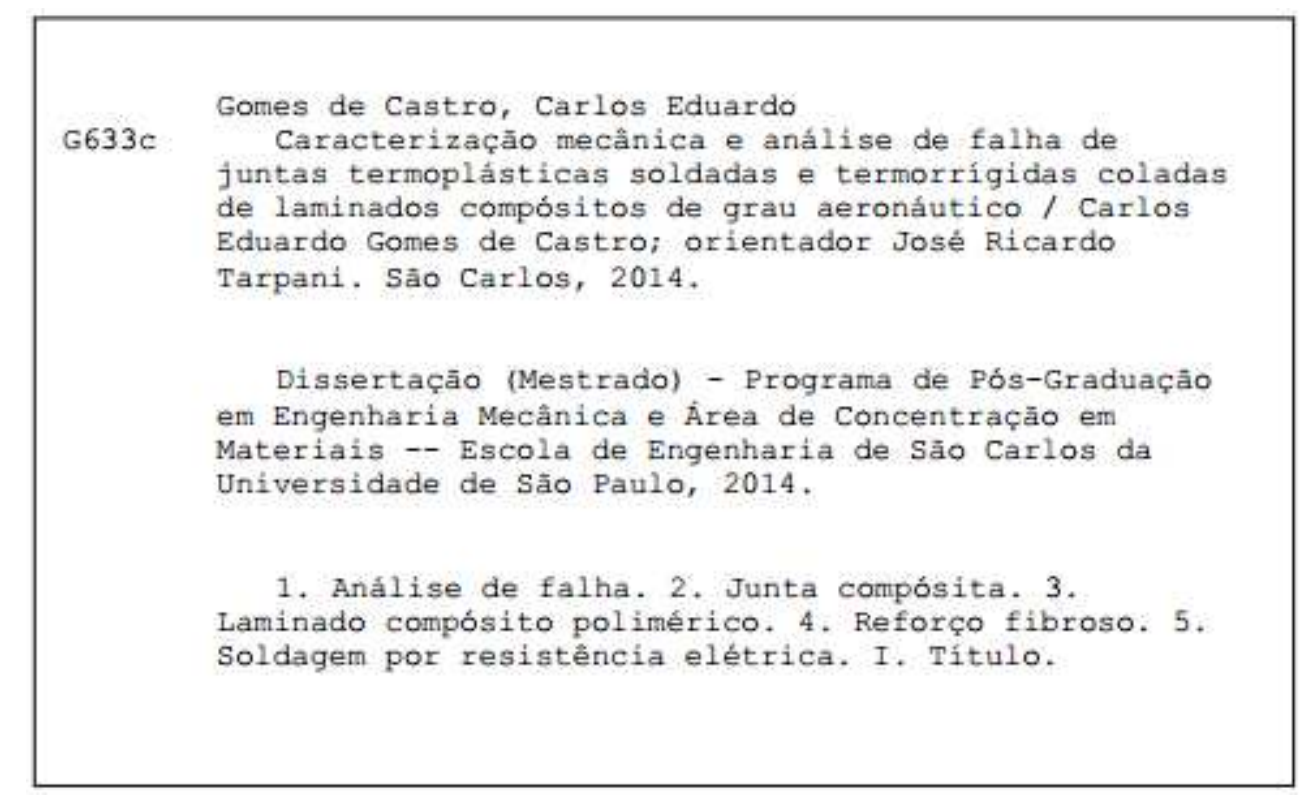




\section{FOLHA DE JULGAMENTO}

Candidato: Engenheiro CARLOS EDUARDO GOMES DE CASTRO.

Título da dissertação: "Caracterização mecânica e análise de falha de juntas termoplásticas soldadas e termorrígidas coladas de laminados compósitos de grau aeronáutico".

Data da defesa: 23/02/2015

Comissão Julgadora:

Prof. Associado José Ricardo Tarpani (Orientador)

(Escola de Engenharia de São Carlos/EESC)

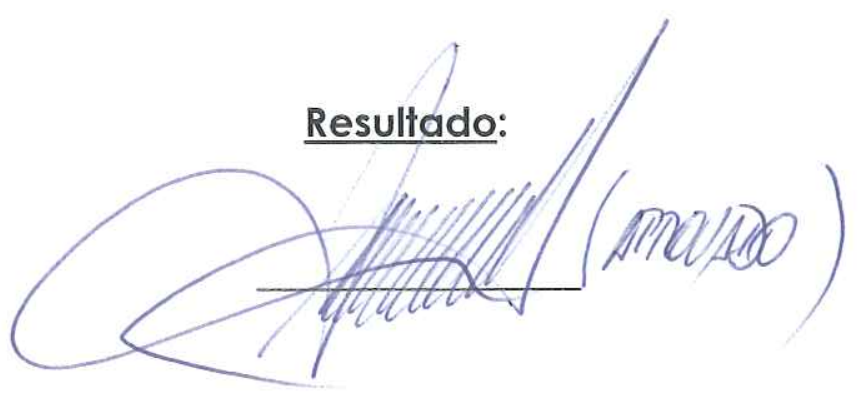

Prof. Dr. Mauricio Vicente Donadon

(Instituto Tecnológico de Aeronáutica/ITA)

Prof. Dr. José Alexandrino de Souza

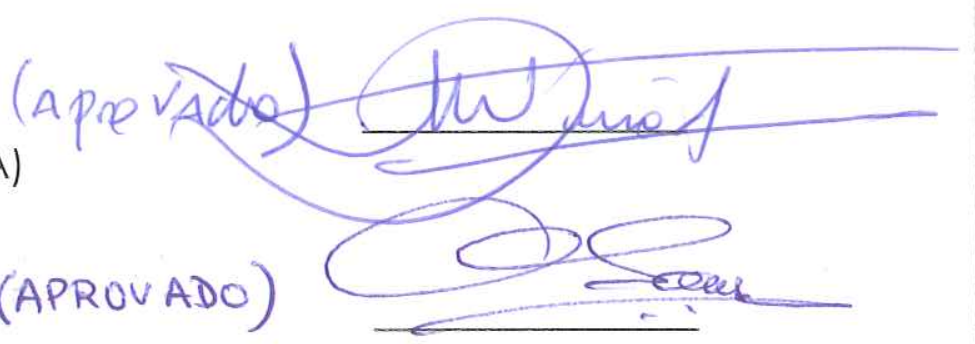

(Universidade Federal de São Carlos/UFSCar)

Coordenador do Programa de Pós-Graduação em Engenheira Mecânica:

Prof. Associado Marcelo Areias Trindade

Presidente da Comissão de Pós-Graduação:

Prof. Associado Paulo César Lima Segantine 

Aos meus pais Waldecir e Lourdes, irmãos Paulo Roberto e Ana Paula, e a minha esposa Meire. 



\section{AGRADECIMENTOS}

Ao orientador, Prof. Dr. José Ricardo Tarpani pela orientação, dedicação e paciência na administração desse trabalho.

Aos técnicos dos laboratórios de microscopia eletrônica de varredura por toda a ajuda na obtenção das imagens de MEV utilizadas neste trabalho.

Aos demais técnicos de laboratório e professores pelas discussões sobre o tema deste trabalho.

Ao Christopher Bordini pela ajuda na preparação das amostras utilizadas na análise por microscopia óptica.

Aos meus pais e irmãos que me deram suporte durante todo o período dedicado a este trabalho.

A minha esposa pela paciência e suporte para que eu pudesse finalizar este trabalho. 

As invenções são, sobretudo, o resultado de um trabalho teimoso.

(Santos Dumont) 

CASTRO, C. E. G. Caracterização mecânica e análise de falha de juntas termoplásticas soldadas e termorrígidas coladas de laminados compósitos de grau aeronáutico. Dissertação (Mestrado) - Escola de Engenharia de São Carlos, Universidade de São Paulo, São Carlos, 2015, 185p.

Este trabalho objetivou a caracterização mecânica e a análise de falha de dois tipos de juntas compósitas através de ensaios mecânicos, em que uma das juntas era composta por dois laminados de fibras de carbono recoberto em ambas as faces por tecido de fibra de vidro reforçando uma matriz termoplástica (PPS-C) unidos via soldagem por resistência elétrica, e a outra confeccionada com dois laminados de fibras de carbono reforçando uma matriz de resina epóxi (EPX-C) unidos via colagem por filme de resina epoxídica. Os dois tipos de juntas foram submetidos a impacto único transversal de 10 $\mathrm{J}$, condicionamento higrotérmico, além de carregamento em fadiga compressiva no plano nas mais diversas combinações destes processos degradativos de suas propriedades mecânicas. Observou-se, que a junta termorrígida colada de EPX-C apresentou a maior resistência mecânica em flexão em quatro pontos (F4P) na condição original (como-manufaturada), assim como os maiores valores de resistência residual para as várias condições de degradação mecânica e higrotérmica a que foi submetida. Por sua vez, a junta termoplástica soldada de PPS-C exibiu, em termos percentuais, menores reduções dos valores de resistência à flexão sob as condições avaliadas, relativamente às perdas apresentadas pela junta EPX-C em idênticas circunstâncias.

A análise macroscópica da superfície de fratura de ambas as juntas indicou que o modo de falha predominante da junta termorrígida foi interfacial enquanto que, para a junta PPS-C, o modo de falha predominante foi o intralaminar. Análises fratográficas através da microscopia eletrônica de varredura (MEV) evidenciaram para a junta termorrígida EPX-C, uma alta adesão entre fibra/matriz, porém uma relativamente fraca interação entre os aderentes (laminado) e o filme adesivo de colagem, enquanto que, para a junta termoplástica PPS-C, reduzidas interações fibra/matriz forem inferidas na camada externa de PPS-V do aderente assim como entre a malha metálica resistiva e os filmes puros de PPS que a revestiam. Em ensaios de resistência ao cisalhamento interlaminar (ILSS), os espécimes retirados da junta EPX-C na condição virgem evidenciaram uma colagem uniforme/homogênea, enquanto que, para a junta PPS-C, os espécimes de ensaio usinados a partir da junta virgem indicaram a ocorrência de efeitos de degradação térmica altamente localizada nas bordas soldadas.

Palavras-chave: Análise de falha; Junta compósita; Laminado compósito polimérico; Reforço fibroso; Soldagem por resistência elétrica. 

CASTRO, C. E. G. Mechanical characterization and failure analysis of thermoplastic welded and thermosetting bonded single-lap joints of aeronautical composite laminates. Thesis (Master) - School of Engineering of São Carlos, University of São Paulo, São Carlos, SP, Brazil, 2015, 185p.

This study aimed to mechanical characterization and failure analysis of two kinds of composite single-lap joints by mechanical tests, in which a single-lap joint was made of two adherents of carbon fibers coated on both sides with glass fiber fabric reinforcing a thermoplastic matrix (PPS-C) welded via resistance welding, and the another type made of two adherents of carbon fibers reinforcing an epoxy matrix (EPX-C) bonded by epoxy adhesive film. The two types of single-lap joints were subjected to single transverse impact of $10 \mathrm{~J}$, hygrothermal conditioning, and compressive fatigue loading in the plane in various combinations of these degradative processes of mechanical properties. It was observed that the thermosetting bonded joint EPX-C showed the highest strength in four point-flexure test in the original condition (as-manufactured), as well as greater residual strength values for the various conditions of mechanical and hygrothermal degradation which was subjected. In turn, the welded thermoplastic joint PPS-C exhibited, in percentage terms, smaller reductions in flexural strength values under the tested conditions, in respect of losses showed by EPX-C in similar circumstances.

Macroscopic analysis of the fracture surfaces from both joints indicated that the predominant failure mode was interfacial to thermosetting while for PPS-C joint, the predominant failure mode was intralaminar. Analysis of fracture surfaces by scanning electron microscopy (SEM) showed, for thermosetting joints EPX-C, a high adhesion between fiber/matrix, but a relatively weak interaction between adherents and the bonding adhesive film, whereas for thermoplastic joint PPS-C, reduced interactions fiber/matrix are inferred in the outer layers of PPS-V and between metal mesh and the pure PPS films that coated it. In the interlaminar shear strength tests (ILSS), the specimens removed from the EPX-C joint in the pristine condition showed a uniform/homogeneous bonding along the joint area, while for PPS-C joint, coupons extracted from pristine condition joint indicated the occurrence of degradation caused by thermal effects localized in the welded edges.

Keywords: Failure analysis, composite lap joint, fibrous polymer matrix composite, adhesive-bonding, resistance-welding. 



\section{LISTA DE FIGURAS}

Figura 1.1 - Classificação dos tipos de compósitos (Adaptado de CALLISTER, 2006) . 36

Figura 1.2 - Representação das múltipas camadas que formam um laminado compósito estrutural e, no detalhe, as fases matriz e de reforço (Adaptado de http://www.cnde.iastate.edu/ultrasonics-and-composites/modeling-cracks-and-

delaminations-carbon-fiber-composites-frank-margetan) 38

Figura 1.3 - Aeronave experimental Grumman X-29 e ilustração do fenômeno de divergência (Adaptado de JONES, 1999) 39

Figura 1.4 - llustração dos modos de falhas intralaminares (Adaptado de ANDERSON, 1995) 40

Figura 1.5 - Delaminações (indicadas por setas) causadas por impacto translaminar em um laminado compósito fibroso (TARPANI et al., 2009) 40

Figura 1.6 - Exemplo de nomenclatura da disposição de camadas para um painel laminado fibroso simétrico e quase-isotrópico (Adaptado de NIU, 1992) 41

Figura 1.7 - Uso progressivo de materiais compósitos em estruturas aeronáuticas comerciais (Adaptado de NIU, 1992)

Figura 1.8 - Porcentagem em peso dos materiais de construção empregados nas aeronaves comerciais: (a) 787, e (b) A350 (Adaptados, respectivamente, de http://www.boeing.com/boeing/commercial/787family/787-10prod.page? http://www.a350xwb.com/sensational/shape)

Figura 1.9 - Seção dianteira da fuselagem do Boeing 787 durante a fabricação (Adaptado de http://www.cnet.com/pictures/in-kansas-where-787-dreamliners-are-bornpictures/)

Figura 1.10 - Aeronave Airbus A350, painel de uma das seções; (Adaptado de http://www.premium-aerotec.com/en/Page1516.html)

Figura 1.11 - Detalhes da união das seções da fuselagem para o Boeing 787 e o Airbus A350. (Adaptado de http://www.newairplane.com/787/\#/design-highlights/visionarydesign/composites/one-piece-barrel-construction/) 46

Figura 2.1 - Distribuição da tensão ao redor dos furos e no adesivo em, respectivamente, juntas mecânicas e coladas (Adaptado de CAMPBEL, 2006) 53 
Figura 2.2 - Perfis típicos das tensões de cisalhamento ("shear stress") e de descascamento trativo ("peel stress") desenvolvidos em uma junta do tipo cisalhante sobreposta simples ("single lap joint") quando esta é macroscopicamente solicitada em tração (Adaptado de SILVA et al., 2009) 53

Figura 2.3 - Pico de tensão transversal ou de descascamento trativo ("peel stress") desenvolvido na borda livre da junta de cisalhamento sobreposta simples (Adaptado de BANEA \& da SILVA, 2009) 54

Figura 2.4 - Tipos mais comuns de juntas aplicadas a laminados compósitos sólidos (Adaptado de CAMPBELL, 2006)

Figura 2.5 - Representação do comportamento de um adesivo frágil e outro dúctil quando aplicados em junta colada submetida à tração (Adaptado de RAPHAEL, 1966)

Figura 2.6 - Distribuição da tensão de cisalhamento ao longo do comprimento da face colada (Adaptado de RAPHAEL, 1966) 56

Figura 2.7 - Modificação de junta denominada ondulada ("wavy") (Adaptado de ZENG \& SUN, 2003) 57

Figura 2.8 - Comparativo da distribuição das tensões de descascamento (a), e de cisalhamento (b) ao longo do adesivo para as juntas do tipo "wavy" sobreposta simples (Adaptado de ZENG \& SUN, 2003) 57

Figura 2.9 - Efeito da espessura do aderente no modo de falha da junta colada (Adaptado de CAMPBELL, 2006) 59

Figura 2.10 - Modos de falha mais comuns para juntas compósitas coladas do tipo cisalhamento simples (Adaptado de ASTM-D5573, 2002)

Figura 2.11 - Esquema do dispositivo de ensaio de impacto de baixa velocidade aplicado em juntas coladas sobrepostas simples (Adaptado de VAIDYA et al., 2006) . 62

Figura 2.12 - Comparativo da tensão de cisalhamento e de descascamento para carregamento trativo no plano (a), e transversal fora do plano (b) (Adaptado de VAIDYA et al., 2006)

Figura 2.13 - Borda livre da junta com e sem a presença do filete de adesivo além das fronteiras da região de união da junta (Adaptado de QUARESIMIN \& RICOTTA, 2006) 
Figura 2.14 - Comparação simplificada da estrutura molecular das resinas termorrígidas e dos polímeros termoplásticos, estes últimos exibindo, respectivamente, cadeias lineares e ramificadas (Adaptado de CAMPBELL, 2006)

Figura 2.15 - Ciclo típico do processo de união por soldagem de termoplásticos (Adaptado de AGEORGES et al., 1998) 66

Figura 2.16 - Interdifusão macromolecular na interface de solda de peças termoplásticas (Adaptado de AGEORGES et al., 1998) 67

Figura 2.17 - Tecnologias e processos de soldagem aplicados aos laminados compósitos termoplásticos (Adaptado de AGEORGES et al., 2001)

Figura 2.18 - Esquemático de um dispositivo para soldagem de juntas sobrepostas termoplásticas por resistência elétrica (Adaptado de STAVROV \& BERSEE, 2005) .... 70

Figura 2.19 - J-nose leading edge do Airbus A340-500/600 e do A380 (http://www.compositesworld.com/articles/thermoplastic-composites-gain-leading-edge-

on-the-a380 acesso em 2012) 75

Figura 2.20 - Propagação das frentes de fusão na interface entre os aderentes (Adaptado de HOU et al.,1999)

Figura 2.21 - Distribuição da temperatura ao longo da linha de união entre aderentes compósitos fibrosos de matriz termoplástica (Adaptado de HOU et al..1999) 77

Figura 2.22 - Efeito da distância do conector à junta na distribuição da temperatura (Adaptado de STAVROV \& BERSEE, 2003) 78

Figura 2.23 - Configuração geométrica do espécime do tipo revestimento/nervura (Adaptado de MINGUET \& O'BRIEN, 1996) 80

Figura 2.24 - Modos de falhas para juntas sobrepostas simples de cisalhamento contendo implante permanente resistivo (Adaptado de DUBÉ, 2007) 82

Figura 3.1 - Aspectos e dimensões finais do CDP termoplástico soldado (a), e do CDP termorrígido colado (b)

Figura 3.2 - (a) Torre de impacto totalmente computadorizada para aquisição de sinais e processamento de dados e semi-automatizada no que se refere a movimentação vertical do impactador e seu mecanismo anti-rebote; (b) Detalhes do impactador e da correspondente ponteira metálica; (c) Detalhes da base de fixação do CDP, indicando- 
se com um círculo vermelho tracejado o ponto de contato entre a ponteira e a zona de sobreposição de uma junta colada de EPX-C

Figura 3.3 - Vistas da face impactada (a), e da face posterior (b) da junta termoplástica soldada PPS-C, em que fica evidente a danificação causada pelo carregamento dinâmico com energia de 15 Joules 90

Figura 3.4 - (a) Três vaporizadores parcialmente imersos em banho aquoso na porção inferior da câmara vedada confeccionada com chapas de policarbonato coladas com adesivo de silicone, e (b) Termômetro analógico situado na porção superior da câmara climática, com 0 bulbo de mercúrio posicionado na altura média das juntas dependuradas 91

Figura 3.5 - Dispositivo de fadiga compressiva no plano, montado no laboratório de Estruturas Aeronáuticas da Universidade de Bath-UK 94

Figura 3.6 - Sistema de F4P em operação, em que se observa o extensômetro que mensura precisamente a deflexão máxima experimentada pela junta durante 0 carregamento fletivo monotônico quase-estático

Figura 3.7 - Esquemático da extração de espécimes ILSS a partir da área de sobreposição de uma junta PPS-C, e configuração do carregamento mecânico dos mesmos

Figura 3.8 - Dispositivo utilizado nos ensaios ILSS de resistência ao cisalhamento interlaminar das juntas compósitas PPS-C e EPX-C

Figura 4.1 - Gráfico dos valores médios de força máxima para os CDPs de PPS-C nas condições Virgem (V), Impactado (I), Condicionado (C), Impactado + Condicionado $(\mathrm{I}+\mathrm{C})$, Fadigado $(\mathrm{F})$, Impactado + Fadigado $(\mathrm{I}+\mathrm{F})$ e Impactado + Condicionado + Fadigado $(\mathrm{I}+\mathrm{C}+\mathrm{F})$

Figura 4.2 - Gráfico dos valores médios de força máxima para os CDPs de EPX-C nas condições Virgem (V), Impactado (I), Condicionado (C), Impactado + Condicionado $(\mathrm{I}+\mathrm{C})$, Fadigado $(\mathrm{F})$, Impactado + Fadigado $(\mathrm{I}+\mathrm{F})$ e Impactado + Condicionado + Fadigado $(\mathrm{I}+\mathrm{C}+\mathrm{F})$ 105

Figura 4.3 - Gráfico comparativo dos valores médios de força máxima para os CDPs de PPS-C e EPX-C para as condições de CDP conforme definidas no capítulo 3 106

Figura 4.4 - Gráficos de rigidez das juntas compósitas durante ensaio de F4P após diversos condicionamentos aplicados as mesmas (Virgem, Impactada, Condicionada, Impactada + Condicionada, Fadigada, Impactada + Fadigada e Impactada + Condicionada + Fadigada conforme definidas no capítulo 3), (a) Juntas PPS-C, e (b) Juntas EPX-C 
Figura 4.5 - Gráfico comparativo dos valores de rigidez para os CDPs de PPS-C e EPX$\mathrm{C}$ para as condições de CDP conforme definidas no capítulo 3 109

Figura 4.6 - Aspectos da interface de fratura entre laminados gerada por ensaio F4P de juntas PPS-C nas condições de virgem (a), e impactada a 10 Joules (b) 110

Figura 4.7 - Aspectos da interface de fratura entre laminados gerada por ensaio F4P de juntas PPS-C nas condições de (a) Condicionada e (b) Impactada + Condicionada + Fadigada 111

Figura 4.8 - Aspectos da interface de fratura entre laminados gerada por ensaio F4P de juntas PPS-C nas condições de impactada + condicionada (a), apenas fadigada (b), e impactada + fadigada 111

Figura 4.9 - Aspectos da interface de fratura entre laminados gerada por carregamento em F4P de juntas EPX-C nas condições de (a) virgem e (b) impactada 112

Figura 4.10 - Aspectos da interface de fratura entre laminados após F4P de juntas EPXC nas condições de (a) Condicionada e (b) Impactada + Condicionada + Fadigada. A seta vermelha aponta alguns danos que parecem ser típicos do condicionamento higrotérmico destas juntas 113

Figura 4.11 - Aspectos da interface de fratura entre laminados gerada por carregamento lento em F4P de juntas EPX-C nas condições de impactada + condicionada (a), apenas fadigada (b), e impactada + fadigada 114

Figura 4.12 - Representação da divisão das áreas de soldagem e colagem para análise de suas características 116

Figura 4.13 - Representação parcial da área pós-ensaio do CDP 23 (V) onde (a) se tem danos na malha metálica (seta azul), vazios (setas amarelas), resina não consolidada (setas vermelhas) e resina degradada devido à alta temperatura atingida na borda (seta laranja) (b) a face oposta com a interface de união irregular (seta vermelha), resina que envolvia a malha metálica (setas amarelas) e camada de fibra de vidro exposta (setas laranjas) 118

Figura 4.14 - Vista da superfície de fratura para o CDP $42(\mathrm{I}+\mathrm{C})$ referente às bordas 1 e 3

Figura 4.15 - Vista da superfície de fratura para o CDP $42(\mathrm{I}+\mathrm{C})$ referente às bordas $2 \mathrm{e}$ 4 ...... 
Figura 4.16 - Vista da superfície de fratura para o CDP $42(\mathrm{I}+\mathrm{C})$ referente ao centro 5 120

Figura 4.17 - Vista da superfície de fratura para o CDP $42(\mathrm{I}+\mathrm{C})$ referente ao centro 5 (face oposta)

Figura 4.18 - Vista da superfície de fratura para o CDP $5(\mathrm{I}+\mathrm{F})$ referente as bordas 1 e 3. Notam-se vazios (setas amarelas), danos na malha metálica (seta vermelha) e marcas da malha metálica na resina (setas roxas) 121

Figura 4.19 - Representação parcial da área pós-ensaio do CDP 1115 (V) onde se tem uma face (a) e a face oposta (b). Em ambas as faces é possível observar vazios na superfície de interface (setas vermelhas) 122

Figura 4.20 - Representação parcial da área pós-ensaio do CDP $4(\mathrm{I}+\mathrm{C})$ onde se tem uma face (a) e a face oposta (b) 124

Figura 4.21 - (a) Esquema de retirada da amostra materialográfica codificada 13 - PPS 6l; (b) Microfotografia da junta PPS na condição apenas impactada, com a face de impacto inferior, sendo o local de observação central, e direção de observação longitudinal à junta. Várias trincas e bolhas são indicadas por círculos vermelhos, e o inserto metálico imerso em zona rica no polímero puro PPS-V é apontado por uma seta azul

Figura 4.22 - (a) Esquema de retirada da amostra materialográfica codificada 14 - PPS 6l; (b) Microfotografia da junta PPS na condição apenas impactada, com a face de impacto inferior, sendo o local de observação central, e direção de observação transversal à junta. Várias trincas e bolhas são indicadas por círculos vermelhos, e o inserto metálico imerso em zona rica no polímero puro PPS-V é apontado por uma seta azul. Potenciais delaminações estão setadas em magenta 127

Figura 4.23 - (a) Esquema de retirada da amostra materialográfica codificada 17 - PPS 6l; (b) Microfotografia da junta PPS na condição apenas simplesmente impactada, com a face de impacto inferior (abaixo da malha metálica), sendo o local de observação a borda lateral da junta, e direção de observação longitudinal à junta. Grande quantidade de bolhas/vazios é observada, sendo algumas delas (mais alongadas) destacadas em (c). O inserto metálico é apontado por uma seta magenta 129

Figura 4.24 - (a) Esquema de retirada da amostra materialográfica codificada 9 - PPS 44 IC; (b) Microfotografia da junta PPS-C na condição impactada+condicionada, com a face de impacto inferior, sendo o local de observação central, e direção de observação longitudinal à junta, onde o inserto metálico é apontado por uma seta amarela; (c) Bolhas/vazios detectados são destacadas em elipses e círculos brancos, respectivamente 131 
Figura 4.25 - (a) Esquema de retirada da amostra materialográfica codificada 10 - PPS - 44 IC; (b) Junta PPS-C na condição impactada+condicionada, com a face de impacto superior, sendo o local de observação central, e direção de observação transversal à junta; Potenciais trincamentos intralaminares longitudinais podem ser postulados (elipse amarela). Uma extensiva trinca horizontal é destacada por uma elipse branca na região já contida pelo núcleo do laminado ou aderente não-impactado de PPS-C; (c) Poucas trincas intralaminares transversais são indicadas por círculos/elipses azuis 133

Figura 4.26 - (a) Esquema de retirada da amostra materialográfica codificada 7 - PPS 44 IC; (b) Microfotografia da junta PPS-C na condição impactada+condicionada, com a face de impacto inferior, sendo o local de observação a borda lateral da junta, e direção de observação longitudinal à junta. Uma considerável presença de bolhas/vazios é destacada por elipses brancas é observada (c). Nota-se a presença de uma trinca horizontal (contida numa elipse roxa) não passível de ser confirmada pela técnica materialográfica empregada; (c) Trincamento intralaminar de proporções substanciais localizado por uma elipse amarela, com o inserto metálico apontado por uma seta azul

Figura 4.27 - (a) Esquema de retirada da amostra materialográfica codificada 15 - EPX 98I (b) Microfotografia da junta EPX-C na condição de somente impactada, com a face de impacto inferior, sendo o local de observação central, e direção de observação longitudinal à junta (a seta azul indica a linha de colagem); (c) Sinais da presença da rede polimérica filamentar para minimizar perda de adesivo durante a colagem da junta são destacados em círculos amarelos. Bolhas/vazios (indicados pelas setas vermelhas) na linha de colagem, assim como áreas ricas em resina (setas brancas) no laminado impactado (inferior) são identificados 138

Figura 4.28 - (a) Esquema de retirada da amostra materialográfica codificada 16 - EPX 98l; (b) Microfotografia da junta EPX-C na condição de somente impactada, com a face de impacto inferior, sendo o local de observação central, e direção de observação transversal à junta. Sinais da presença da rede polimérica filamentar para minimizar perda de adesivo líquido durante a colagem da junta são destacados em elipses amarelas. A seta verde indica a linha de colagem, enquanto setas azuis apontam para numerosos e longos trincamentos no aderente não-impactado (superior), na forma de delaminações e trincas intralaminares transversais 139

Figura 4.29 - (a) Esquema de retirada da amostra materialográfica codificada 11 - EPX 12IC; (b) Microfotografia da junta EPX-C na condição de impactada+condicionada, com a face de impacto inferior, sendo o local de observação central, e direção de observação longitudinal à junta. (c) A seta verde indica a linha de colagem 141

Figura 4.30 - (a) Esquema de retirada da amostra materialográfica codificada 12 - EPX 12IC; (b) Microfotografia da junta EPX-C na condição de impactada+condicionada, com a face de impacto inferior, sendo o local de observação central, e direção de observação transversal à junta. A seta verde indica a linha de colagem, enquanto as setas brancas apontam para os vários trincamentos identificados. Defeitos em profusão na linha de colagem (bolhas/vazios) são destacados por círculos e elipses amarelas 142 
Figura 4.31 - Espécimes impactados e analisados por inspeção termográfica onde a) PPS-C impactado e b) EPX-C impactado. A seta (amarela) indica o centro do espécime afetado pelo impacto e a dupla seta (em branco), ilustra a largura da área de junção 143

Figura 4.32 - (a,b) Vista de fibras de vidro que sofreram completo efeito de desacoplamento da matriz de PPS na condição $(\mathrm{I}+\mathrm{C})$ onde as setas vermelhas apontam para fibras e conjuntos de fibras completamente descobertas quanto ao seu revestimento polimérico original, caracterizando uma típica falha adesiva; Para o CDP virgem em (c) espaços ocupados pelas fibras descoladas integralmente de seus sítios originais são também indicados por setas; (d) fibra exposta e sítio outrora ocupado por fibras 146

Figura 4.33 - $(a, b)$ Claros indicativos da falta de molhabilidade da malha de aço pelo polímero PPS 146

Figura 4.34 - (a) Sinalização de extrema ductilidade (setas vermelhas) (e, muito provavelmente, reduzida resistência mecânica) da malha metálica de aquecimento para soldagem localizada entre os laminados termoplásticos fibrosos (aderentes) da junta PPS-C; Comprovação visual adicional da baixa interação metal/polímero (setas azuis) e (c) massiva presença de vazios/bolhas gerados na soldagem pelo aprisionamento de grande quantidade de ar entre os aderentes (setas amarelas) 148

Figura 4.35 - $(a, b)$ Fotomicrofratografias obtidas por microscópio eletrônico de varredura da superfície de ruptura de corpo de prova de junta EPX-C virgem pós-carregamento em F4P

Figura 4.36 - (a-c) Fotomicrofratografias de varredura eletrônica de espécime previamente impactado, subseqüentemente condicionado, e finalmente fraturado em F4P 150

Figura 4.37 - $(a, b)$ Fotomicrofratografias de varredura eletrônica de espécime simplesmente fadigado em compressão em condições de amplitude constante de tensão 151

Figura 4.38 - (a) Fotomicrofratografia de varredura eletrônica de espécime impactado e fadigado destacando-se os danos decorrentes do carregamento dinâmico; (b) Destacando-se danos oriundos do carregamento cíclico compressivo 152

Figura 4.39 - (a-e) Junta EPX-C impactada, condicionada ambientalmente, fadigada em compressão e finalmente fraturada em F4P, em que se verifica a presença intencional de uma rede trançada filamentar polimérica, dos conseqüentes defeitos de manufatura do tipo-bolha/vazio na interface colada, além de danos de aspecto alveolar impostos ao adesivo epoxídico possivelmente pelo envelhecimento ambiental aplicado à junta termorrígida 153 
Figura 4.40 - $(a, b)$ Aspectos de fratura por F4P observados na interface entre os dois laminados EPX-C de uma junta sobreposta, em que se verificam regiões de boa qualidade do produto, visto que, mesmo sob a ação prévia de impacto, condicionamento ambiental e fadiga compressiva, uma muito boa adesão ainda permanece entre fases matriz e de reforço, tal como desejável para aderentes da classe EPX-C 153

Figura 4.41 - Representa o gráfico obtido da média das tensões máximas para cada posição da amostra retirada da área de soldagem da junta de PPS-C virgem 155

Figura 4.42 - Gráfico da tensão máxima para cada posição da amostra da área de soldagem da junta de PPS-C impactada 156

Figura 4.43 - Gráfico obtido da média das tensões máximas para cada posição da amostra retirada da área de colagem da junta de EPX-C do tipo virgem 157

Figura 4.44 - Gráfico da tensão máxima para cada posição da amostra da área de colagem da junta de EPX-C do tipo impactada 158

Figura 4.45 - Gráfico comparativo da média das tensões máximas para cada posição da amostra retirada da área de soldagem e colagem para a junta de PPS-C e EPX-C do tipo virgem, respectivamente 159

Figura 4.46 - Gráfico comparativo da média das tensões máximas para cada posição da amostra retirada da área de soldagem e colagem para a junta de PPS-C e EPX-C impactadas, respectivamente 159

Figura B.1 - Gráficos de força x deslocamento para o PPS-C. Comparando as condições "virgem versus impactado" (a), "virgem versus condicionado" (b), "virgem versus impactado + condicionado" (c), "virgem versus fadigado" (d), "virgem versus impactado + fadigado" (e), "virgem versus impactado + condicionado + fadigado" (f). 182

Figura B.2 - Gráficos de força x deslocamento para o EPX-C. Comparando as condições "virgem versus impactado" (a), "virgem versus condicionado" (b), "virgem versus impactado + condicionado" (c), "virgem versus fadigado" (d), "virgem versus impactado + fadigado" (e), "virgem versus impactado + condicionado + fadigado" (f) 185 



\section{LISTA DE TABELAS}

Tabela 2.1 Comparação entre várias técnicas de união de polímeros e compósitos termoplásticos (Adaptado de SILVERMAN \& GRIESE, 1989) 69

Tabela A.1 - Valores de força, deslocamento máximo e desvio padrão obtidos nos ensaios de flexão sob quatro pontos para as juntas termoplásticas soldadas de PPS-C 174

Tabela A.2 - Valores de força, deslocamento máximo e desvio padrão obtidos nos ensaios de flexão sob quatro pontos para as juntas termorrígidas coladas de EPX-C

Tabela A.3 - Para a junta termoplástica soldada de PPS-C o "X" marca a análise que foi realizada para cada CDP de acordo com a sua condição. Portanto, os CDPs assinalados abaixo tiveram a superfície de fratura fotografada, inspecionada por estereoscopia e microscopia eletrônica de varredura (MEV) 175

Tabela A.4 - Para o EPX-C o "X" marca a análise que foi realizada para cada CDP de acordo com a sua condição. Portanto, os CDPs assinalados abaixo tiveram a superfície de fratura fotografada, inspecionada por estereoscopia e microscopia eletrônica de varredura (MEV) 176

Tabela A.5 - Valores de tensão obtidos no ensaio de ILSS para cada amostra com a respectiva média e desvio padrão para cada posição (de 1 a 9) na junta de PPS-C

Tabela A.6 - Valores de tensão obtidos no ensaio de ILSS para cada posição (de 1 a 9) na junta de PPS-C previamente impactada

Tabela A.7 - Valores de tensão obtidos no ensaio de ILSS para cada amostra com a respectiva média e desvio padrão para cada posição (de 1 a 9) na junta de EPX-C

Tabela A.8 - Valores de tensão obtidos no ensaio de ILSS para cada posição (de 1 a 9) na junta de EPX-C previamente impactada 

LISTA DE SIGLAS, ABREVIATURAS E SÍMBOLOS

3D Tridimensional

ASTM American Society for Testing and Materials

b Largura do espécime

C Condicionada Higrotermicamente

CDP Corpo de Prova

EPX-C Epóxi Reforçado com Fibras Contínuas de Carbono

F $\quad$ Fadigada

FC Fibras de carbono

FP4 Ensaio mecânico de flexão sob quatro pontos

FV Fibras de vidro

h Espessura do espécime

HS5 Harness Satin 5

HS8 Harness Satin 8

$\mathrm{Hz} \quad \mathrm{Hertz}$

I Impactada

ILSS Interlaminar Shear Strength

MEV Microscopia Eletrônica de Varredura

PEEK Poly-ether-ether-ketone

PEI Poli-Éter-Imida

PEKK Poli-Éter-Cetona-Cetona

PES Poli-Éter-Sulfona

PPS Poli-Sulfeto-de-Fenileno

PPS-C Poli-Sulfeto-de-Fenileno Reforçado com Fibras Contínuas de Carbono

PPS-F Filme de resina PPS 
PPS-V Poli-Sulfeto-de-Fenileno Reforçado com Fibras Contínuas de Vidro R Resistência Elétrica

T Resistência Máxima ao Cisalhamento Interlaminar

t Tempo

$T_{g} \quad$ Temperatura de Transição Vitrea

$\mathrm{T}_{\mathrm{m}} \quad$ Temperatura de Fusão

V Virgem 


\section{SUMÁRIO}

RESUMO

ABSTRACT

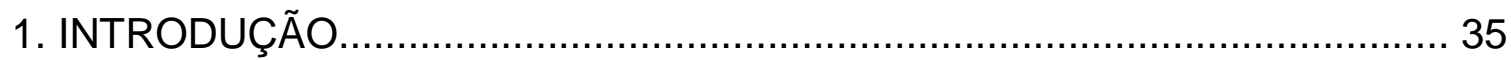

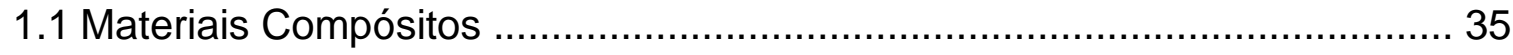

1.2 Classificação dos Materiais Compósitos ……….......................................... 36

1.3 Vantagens dos Compósitos Fibrosos em Projetos Estruturais .................... 37

1.4 Mecanismos de Falha de Compósitos Fibrosos .......................................... 39

1.5 Orientação Preferencial de Fibras Contínuas ............................................ 41

1.6 Aplicações dos Materiais Compósitos ........................................................ 42

1.7 Higrotermina e impacto de baixa energia em materiais compósitos laminados 46

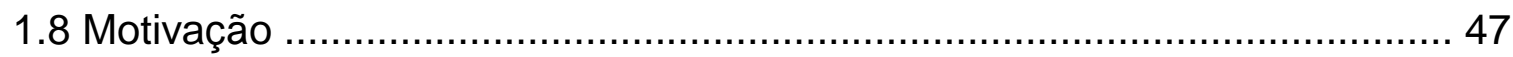

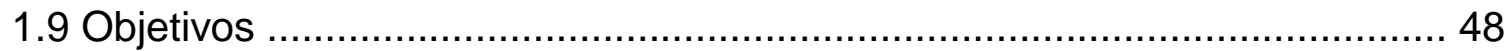

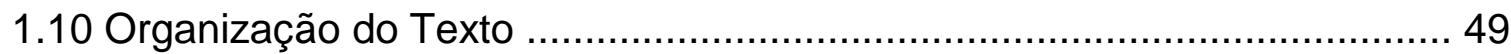

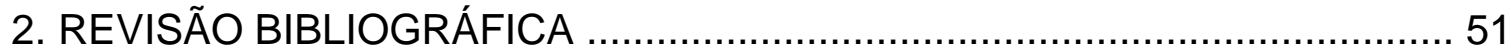

2.1 Juntas em Materiais Compósitos ……………...................................... 51

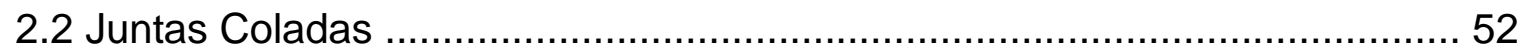

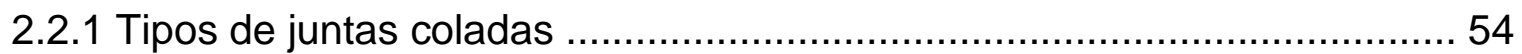

2.2.2 Influência da espessura do laminado no desempenho da junta ............... 58

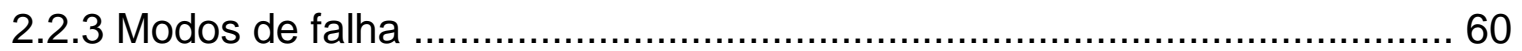

2.2.4 Aspectos gerais e desempenho de juntas coladas compósitas ................ 61

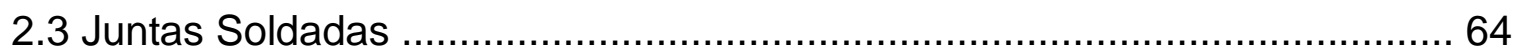

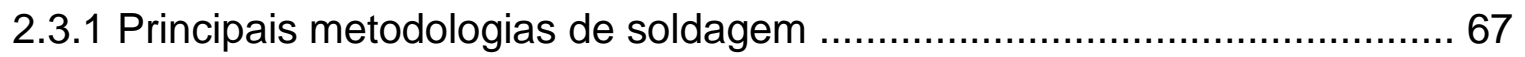

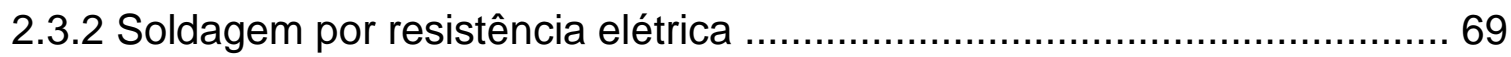

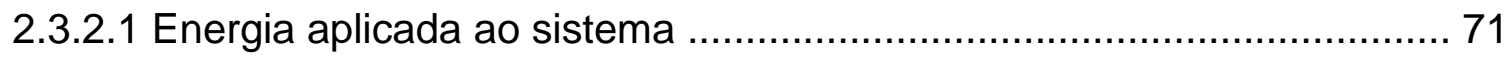

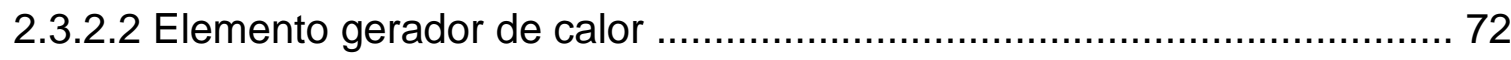

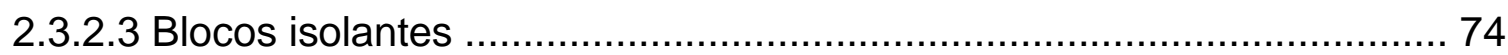

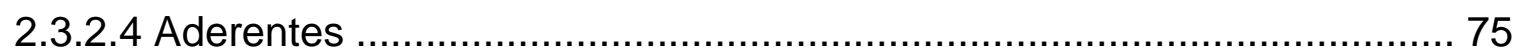

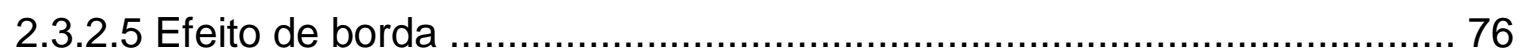

2.3.2.6 Geometria de junta para corpos de provas ………………................ 79 
2.4 Principais Normas Técnicas da American Society for Testing and Materials

3. MATERIAIS E MÉTODOS 85

3.1 Tipos de corpos de provas e condições de danificação prévia dos espécimes 85

3.2 Ensaio de resistência residual via flexão sob quatro pontos 95

3.3 Ensaio de resistência residual ao cisalhamento interlaminar 97

3.4 Estereoscopia 99

3.5 Microscopia óptica de reflexão de luz . 99

3.6 Microscopia eletrônica de varredura 100

4. RESULTADOS E DISCUSSÕES 102

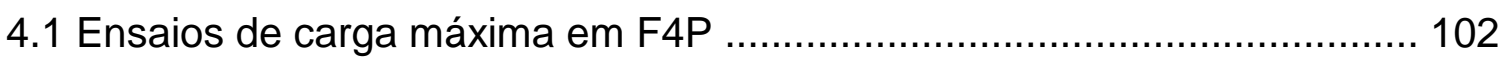

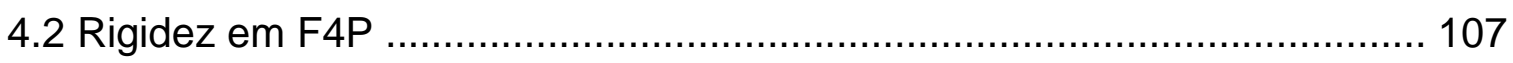

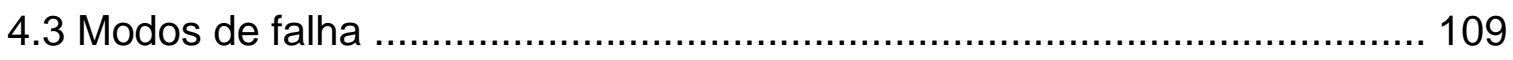

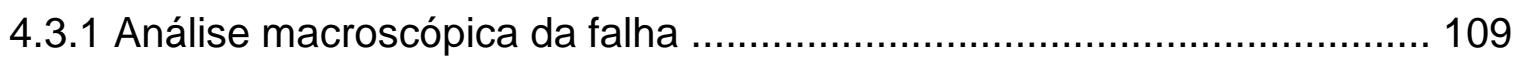

4.3.2 Análise mesoscópica da falha (estereoscópio) ..................................... 116

4.3.3 Análise microscópica da falha (microscópio óptico de reflexão) .............. 124

4.3.3.1 Junta Simplesmente Impactada: Região Central, Vista Longitudinal ... 125

4.3.3.2 Junta Simplesmente Impactada: Região Central, Vista Transversal ... 126

4.3.3.3 Junta Simplesmente Impactada: Região de Borda, Vista Longitudinal 128

4.3.3.4 Junta Impactada e Envelhecida Higrotermicamente: Região Central, Vista Longitudinal 130

4.3.3.5 Junta Impactada e Envelhecida Higrotermicamente: Região Central, Vista Transversal 131

4.3.3.6 Junta Impactada e Envelhecida Higrotermicamente: Região de Borda, Vista Longitudinal 133

4.3.3.7 Junta Simplesmente Impactada: Região Central, Vista Longitudinal ... 136

4.3.3.8 Junta Simplesmente Impactada: Região Central, Vista Transversal ... 138

4.3.3.9 Junta Impactada e Envelhecida Higrotermicamente: Região Central, Vista Longitudinal 140

4.3.3.10 Junta Impactada e Envelhecida Higrotermicamente: Região Central, Vista Transversal 141

4.4. Análise microscópica da falha (MEV) 145

4.4.1 Juntas soldadas - PPS-C 145 


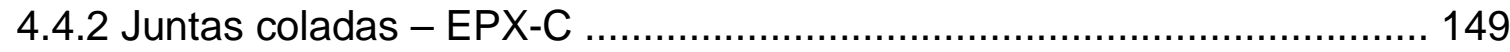

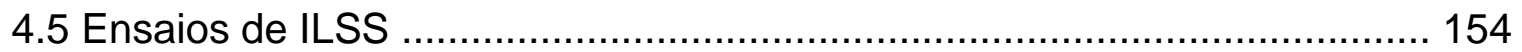

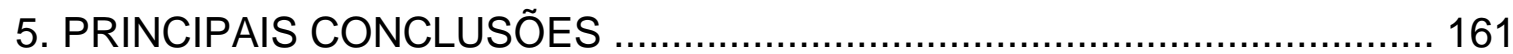

6. SUGESTÕES PARA TRABALHOS FUTUROS ……............................... 163

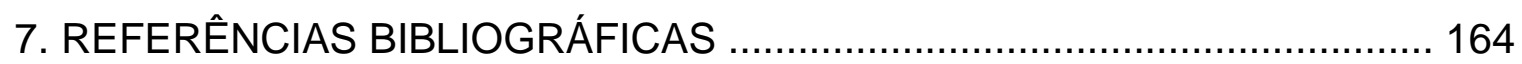

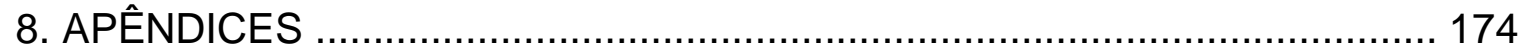

8.1 Apêndice A - Tabelas .............................................................. 174

8.2 Apêndice B - Figuras .................................................................. 179 



\section{INTRODUÇÃO}

\subsection{Materiais Compósitos}

Materiais compósitos são materiais multifásicos que exibem de maneira significativa e proporcional às respectivas frações volumétricas, as propriedades de ambas as fases matriz e de reforço que os constituem, obtendo-se desta forma uma melhor combinação das propriedades mecânicas para o produto final (CALLISTER, 2006).

Para compósitos poliméricos reforçados com fibras, os polímeros (matriz) e as fibras (reforço) com excelentes propriedades física e mecânica são combinados para formar um novo material com propriedades superior. Onde, os polímeros podem ser dúcteis ou frágeis e em geral proporcionam boa resistência a ambientes químicos. Já as fibras caracterizam-se por possuir alta resistência e módulo, mas são frágeis. Assim, a combinação das duas fases produz um material com resistência mecânica próxima à da fibra e com a resistência química do polímero. Adicionalmente, a sinergia nesta combinação também pode proporcionar ao novo material, resistência na propagação de trincas e de absorver energia durante a deformação (HULL, 1995).

Contudo, o novo material pode não alcançar a sinergia pretendida com a combinação do polímero com a fibra, pois a interface fibra-matriz é igualmente importante no desempenho mecânico do compósito. Assim, o sucesso do desenvolvimento do novo material é determinado pela qualidade da interface fibramatriz. Deste modo, tratamentos químicos podem ser aplicados nas fibras a fim de melhorar a qualidade da interface fibra-matriz proporcionado melhor adesão e performance mecânica (HYER, 1998). 


\subsection{Classificação dos Materiais Compósitos}

CALLISTER (2006) classifica os compósitos em três grandes grupos (Figura 1.1) os reforçados por partículas, os reforçados por fibras e os de emprego estrutural de alta responsabilidade.

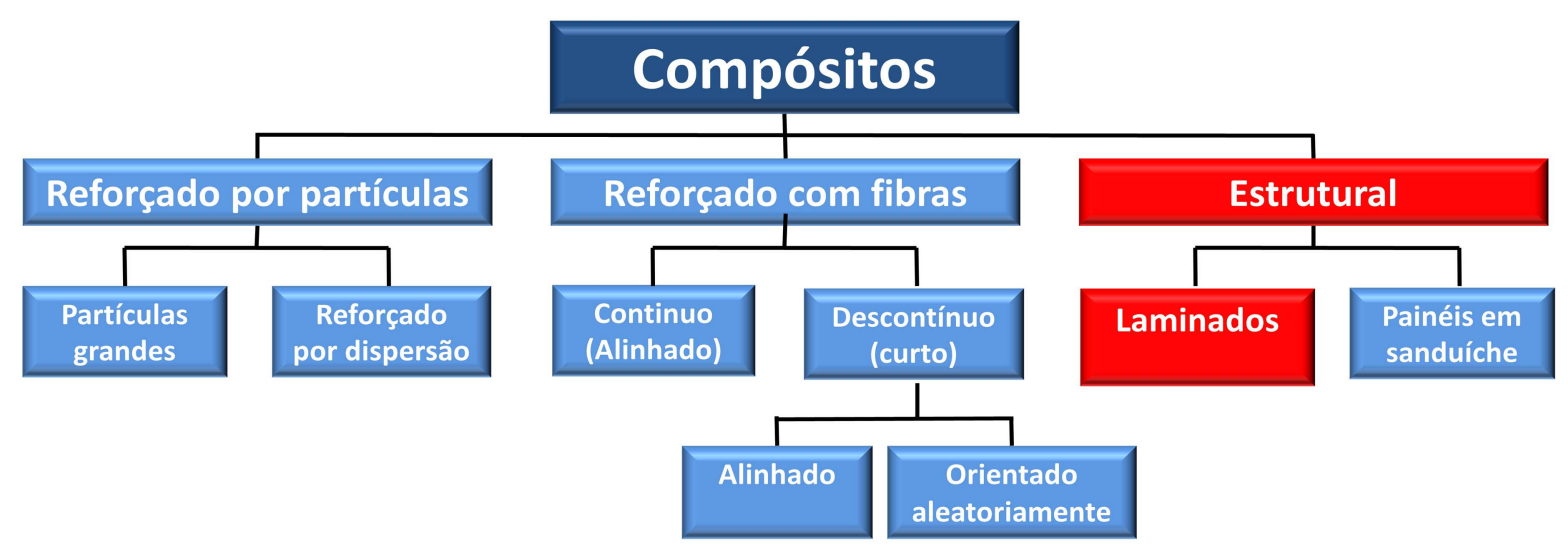

Figura 1.1 - Classificação dos tipos de compósitos (Adaptado de CALLISTER, 2006).

No presente texto, ênfase é dada ao uso dos compósitos do tipo estrutural, mais precisamente aos laminados constituídos de matriz polimérica (termorrígida ou termoplástica) reforçada com fibras contínuas essencialmente contidas no plano do laminado e orientadas nas quatro direções principais, quais sejam: $0,+45,-45,90^{\circ}$.

A mistura e a consolidação físico-química desses dois materiais (matriz e fibra) resultam em um único material exibindo elevadas rigidez e resistência mecânicas específicas (propriedades por unidade de massa), ou seja, excepcional eficiência estrutural.

O papel da matriz é manter as fibras na sua posição original, protegê-las da abrasão e intempéries, além de contribuir na transferência de carga para e entre as fibras, bem como prover resistência ao cisalhamento interlaminar. Já o reforço determina essencialmente a resistência mecânica e a rigidez do laminado (CAMPBELL, 2006).

Para a matriz polimérica são usados dois tipos de polímeros, os termorrígidos e os termoplásticos. As resinas termorrígidas mais utilizadas para aplicações em 
estruturas aeronáuticas são as do tipo epóxi, caracterizadas principalmente por um ótimo balanço entre as propriedades mecânicas, físicas e químicas como de processabilidade perante suas concorrentes.

O segundo grupo de polímeros são os termoplásticos e, enfatizando o uso em estruturas aeronáuticas, destacam-se o PEEK (poli-éter-éter-cetona), PEI (poli-éterimida) e o PPS (poli sulfeto de fenileno), que se caracterizam por uma menor absorção de umidade, maior tolerância a danos e superior temperatura de serviço comparativamente à imensa maioria dos termorrígidos. Como vantagens adicionais apresentam a possibilidade de reparação relativamente simples, e de reciclagem de rejeitos contribuindo assim para minimizar o impacto ambiental.

Embora existam outros tipos de materiais compósitos, com matrizes cerâmicas e matrizes metálicas, os compósitos poliméricos reforçados por fibras contínuas respondem quase que pela totalidade do emprego desta classe de materiais na indústria aeronáutica, em especial a civil ou comercial.

\subsection{Vantagens dos Compósitos Fibrosos em Projetos Estruturais}

Dado que as fibras exibem máximo desempenho ao longo de seu comprimento, uma característica importante dos materiais compósitos fibrosos é que o projetista tem a possibilidade de orientar as camadas individuais fibrosas que formam 0 laminado (Figura 1.2) de modo a adequar a estrutura de material compósito aos esforços principais aplicados à mesma em serviço, otimizando desta forma seu desempenho mecânico em serviço, assim como reduzindo o peso estrutural.

A possibilidade de se criarem laminados anisotrópicos, em que se dá preferência à disposição de uma maior quantidade de fibras numa direção especifica durante o processo de laminação é um recurso freqüentemente utilizado para otimizar estruturas compósitas. Como exemplo, pode-se citar o projeto da asa da aeronave experimental Grumman X-29 (Figura 1.3). 


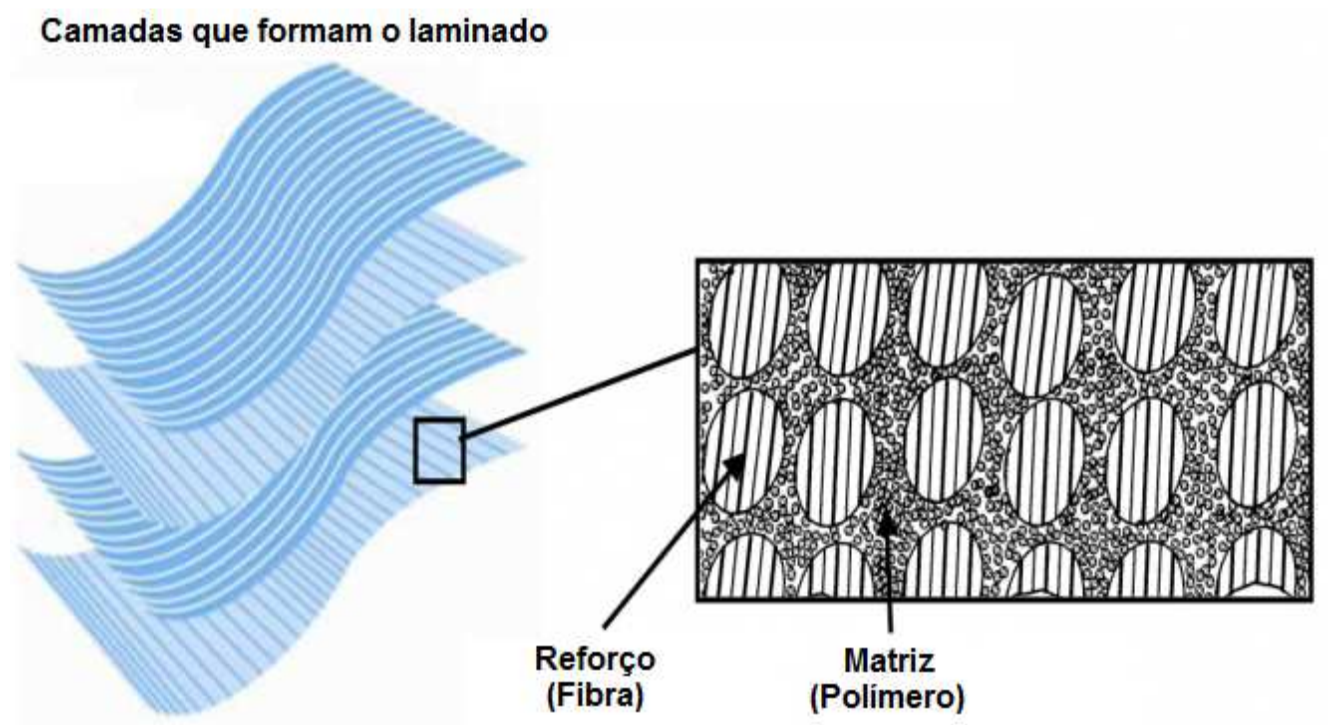

Figura 1.2 - Representação das múltipas camadas que formam um laminado compósito estrutural e, no detalhe, as fases matriz e de reforço (Adaptado de http://www.cnde.iastate.edu/ultrasonics-and-composites/modeling-cracks-and-delaminationscarbon-fiber-composites-frank-margetan)

Esta aeronave apresenta um par de asas com enflechamento negativo ("forward swept'). Este tipo de asa é sujeita ao fenômeno aeroelástico de divergência, pois, durante $\mathrm{o}$ vôo, as asas são submetidas às forças aerodinâmicas que tendem a torcer a ponta da asa ao longo de seu eixo longitudinal, aumentando seu ângulo de ataque o que pode levar a ruptura do componente. Se neste tipo de projeto de asa fossem utilizadas ligas metálicas, a estrutura teria que ser construída com muitos reforçadores para impedir que ocorresse o fenômeno de divergência, o que aumentaria consideravelmente seu peso.

Para superar este problema de engenharia, no projeto do X-29 usa-se um laminado de carbono que produz acoplamento entre torção e flexão (provocado devido à natureza anisotrópica obtida no seqüenciamento das camadas do tecido empregado) para evitar o fenômeno da divergência, ou seja, quando cargas aerodinâmicas agem no sentido de torcer a asa (no sentido horário), o acoplamento resiste a essas cargas minimizando a sua torção e assim o problema de divergência (JONES, 1999).

No entanto, a possibilidade de se conceberem e se criarem estruturas compósitas fibrosas anisotrópicas também leva o projetista a enfrentar problemas 
como a dificuldade de previsão do comportamento mecânico do material, principalmente devido à diversidade dos modos de falha inerentes aos compósitos.

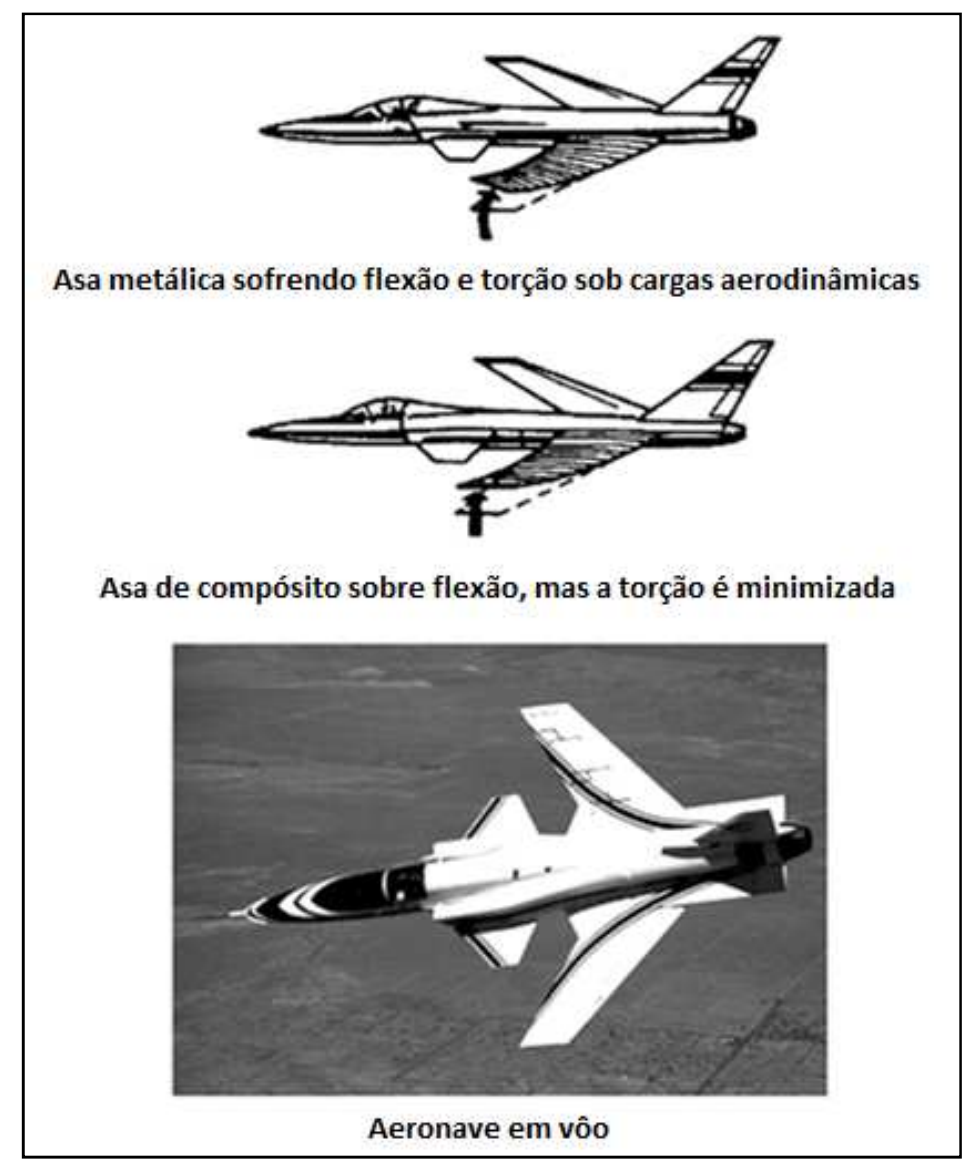

Figura 1.3 - Aeronave experimental Grumman X-29 e ilustração do fenômeno de divergência (Adaptado de JONES, 1999).

\subsection{Mecanismos de Falha de Compósitos Fibrosos}

A Figura 1.4 ilustra os 5 principais modos de falha de uma lâmina compósita fibrosa individual. Dentre estes modos de falha intralaminares freqüentemente observáveis em laminados compósitos fibrosos, destacam-se os seguintes mecanismos, não necessariamente obedecendo cronologicamente esta ordem estabelecida: (1) arrancamento da fibra ("fiber pull out"), (2) ancoramento de trinca por fibras ("fiber bridging"), (3) descolamento de fibra da matriz ("fiber debonding"), (4) ruptura da fibra ("fiber fracture") e (5) trincamento da matriz ("matrix cracking"). 


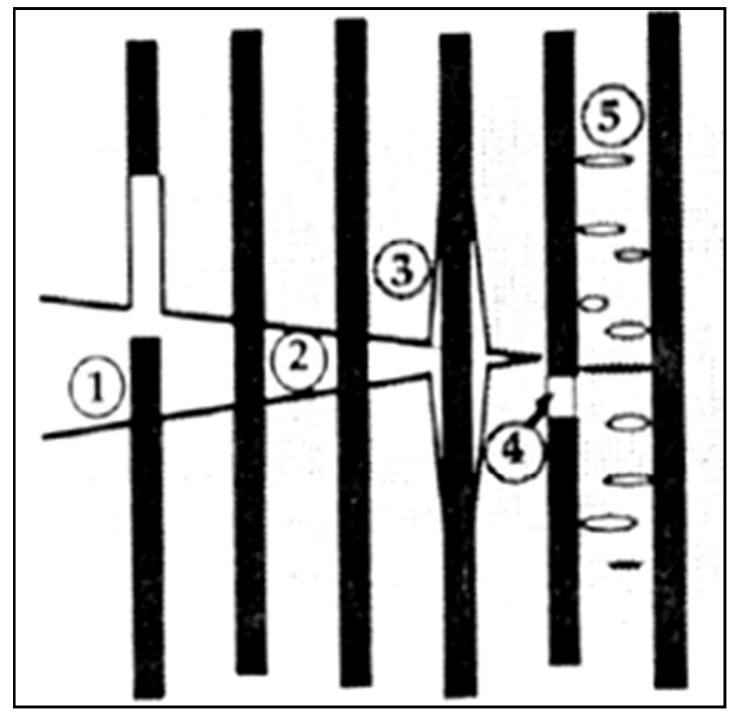

Figura 1.4 - llustração dos modos de falhas intralaminares (Adaptado de ANDERSON, 1995).

No entanto, considerando que o laminado compósito é formado por um conjunto justaposto de lâminas individuais fibrosas, merece ser considerado o importante mecanismo de falha interlaminar denominado delaminação, que consiste no descolamento entre camadas adjacentes do laminado. O fenômeno ocorre principalmente no caso de um elevado nível de tensão aplicada perpendicularmente ao plano do laminado, em especial sob condições de impacto (Figura 1.5).

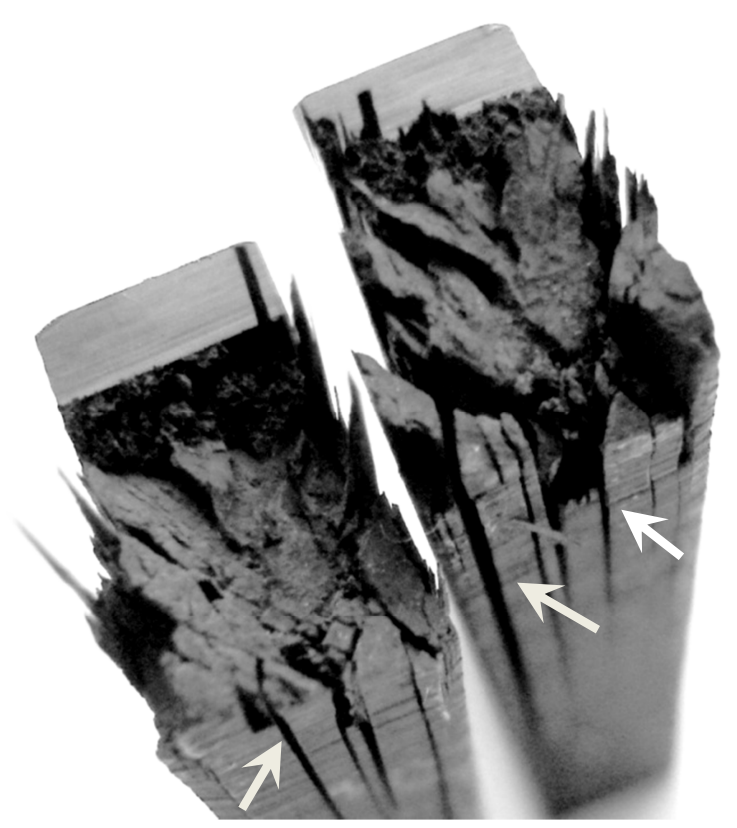

Figura 1.5 - Delaminações (indicadas por setas) causadas por impacto translaminar em um laminado compósito fibroso (TARPANI et al., 2009). 


\subsection{Orientação Preferencial de Fibras Contínuas}

Conforme já mencionado, os compósitos estruturais fibrosos apresentam como vantagem a possibilidade de dispor as camadas de fibras contínuas em determinada ordem ou orientação visando-se conseguir as propriedades mecânicas desejadas aliadas a um baixo peso estrutural.

Como exemplo toma-se o caso de um componente solicitado em tração. Em seu projeto, a disposição das camadas contendo fibras há de favorecer o alinhamento das mesmas no sentido do carregamento trativo, ou seja, fibras paralelas a direção de aplicação do esforço mecânico, seja este imposto de modo quase-estático, dinâmico (impacto ou fadiga).

Para ilustrar as direções das fibras em um laminado é utilizada uma nomenclatura especial, tal como descrita na Figura 1.6.

Nota-se que os ângulos direcionais das camadas de fibras mostradas são apresentados entre colchetes, iniciando-se pela camada externa superior até a camada externa inferior.
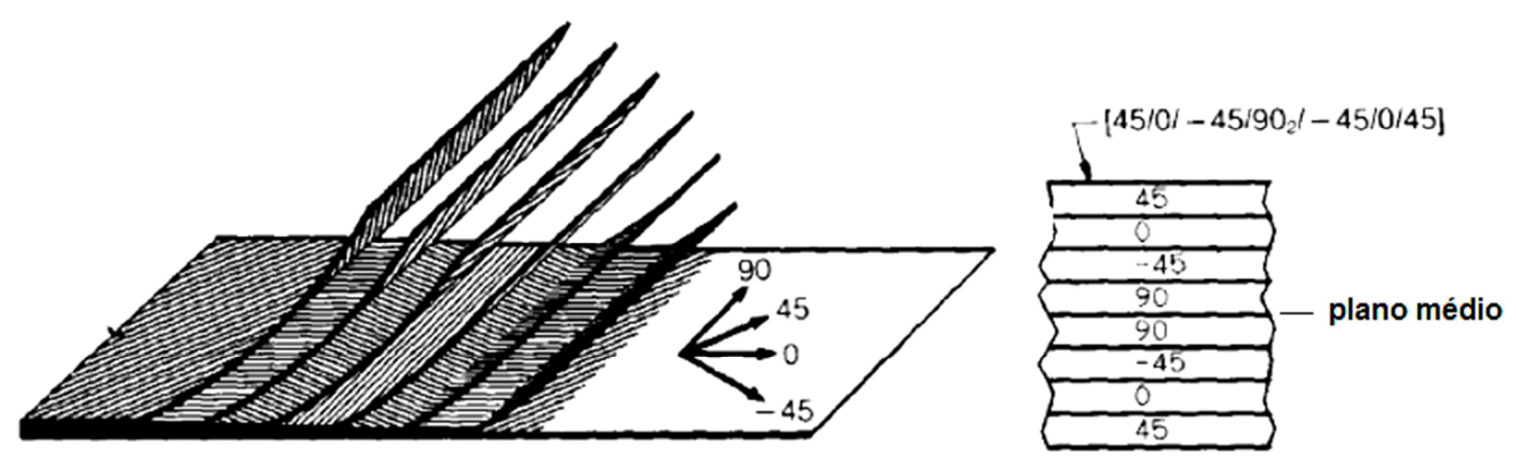

Figura 1.6 - Exemplo de nomenclatura da disposição de camadas para um painel laminado fibroso simétrico e quase-isotrópico (Adaptado de NIU, 1992).

Portanto, no projeto de qualquer componente fabricado em material compósito estrutural, o projetista calcula qual deve ser o número de camadas de fibras e qual a orientação que cada camada deve apresentar dentro do laminado para que este apresente resistência e rigidez necessárias frente ao sistema de carregamento a ser imposto durante sua operação em serviço. 
Atualmente, ferramentas computacionais com base no método dos elementos finitos, combinadas com critérios de falha, auxiliam os projetistas na complexa análise estrutural para a manufatura de peças, componentes e estruturas fabricadas em materiais compósitos.

\subsection{Aplicações dos Materiais Compósitos}

O uso de compósitos em estruturas, especialmente aqueles reforçados com fibra de carbono, permitem considerável redução de peso destas, assim como contribuí no incremento da resistência à corrosão e no desempenho em fadiga de componentes estruturais primários e secundários de aeronaves de última geração, satélites, foguetes, submarinos, plataformas marítimas entre outras aplicações (NETO \& PARDINI, 2006)

$\mathrm{Na}$ aviação civil ou comercial, o uso de materiais compósitos começou efetivamente a partir do início da década de $80 \mathrm{com}$ a fabricação de estruturas secundárias como radome e carenagens, passando para estruturas primárias como superfícies de comando, até meados dos anos 2000 com a aplicação em asas e fuselagem.

Desde então, o uso crescente de compósitos em estruturas primárias das aeronaves, em substituição àquelas confeccionadas particularmente em ligas de alumínio, proporcionou aos fabricantes o projeto e a manufatura de estruturas mais leves, contribuindo para a redução do gasto de combustível, aumento da autonomia de vôo e no significativo incremento da carga paga ("pay load") e do número de passageiros transportados. Esta evolução na aplicação dos materiais compósitos em aeronaves comerciais, desde áreas não críticas até o emprego em estruturas primárias, é ilustrada na Figura 1.7.

Os dois maiores fabricantes de aeronaves comerciais da atualidade, Boeing e Airbus, através de seus respectivos modelos de longo percurso B787 e A350 venceram o desafio de fabricar aeronaves de grande porte para uso civil com aproximadamente $50 \%$ do seu peso em materiais compósitos (Figura 1.8). 


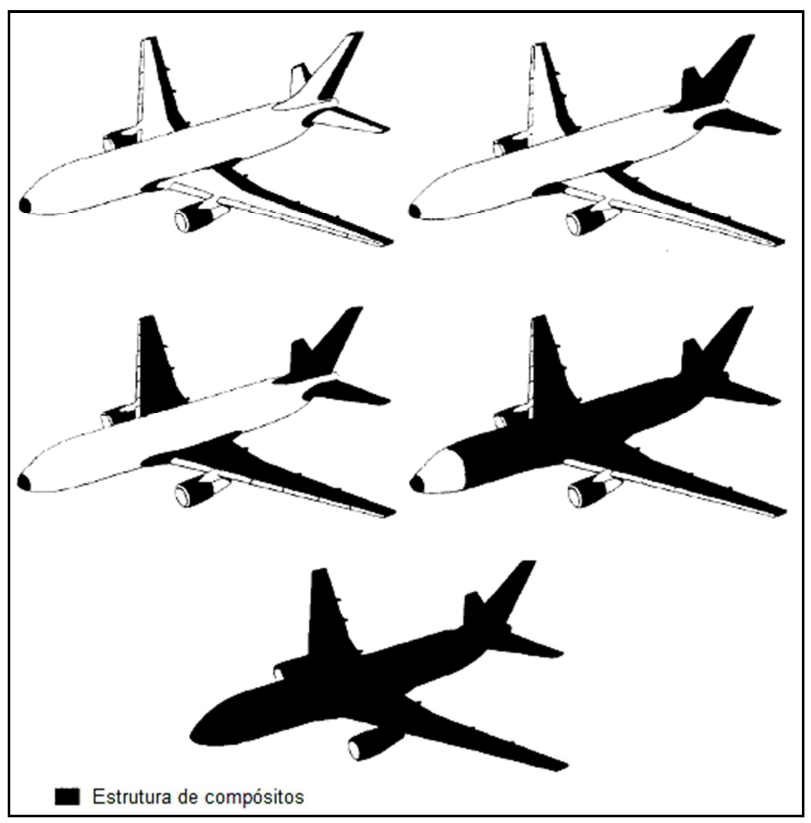

Figura 1.7 - Uso progressivo de materiais compósitos em estruturas aeronáuticas comerciais (Adaptado de NIU, 1992).

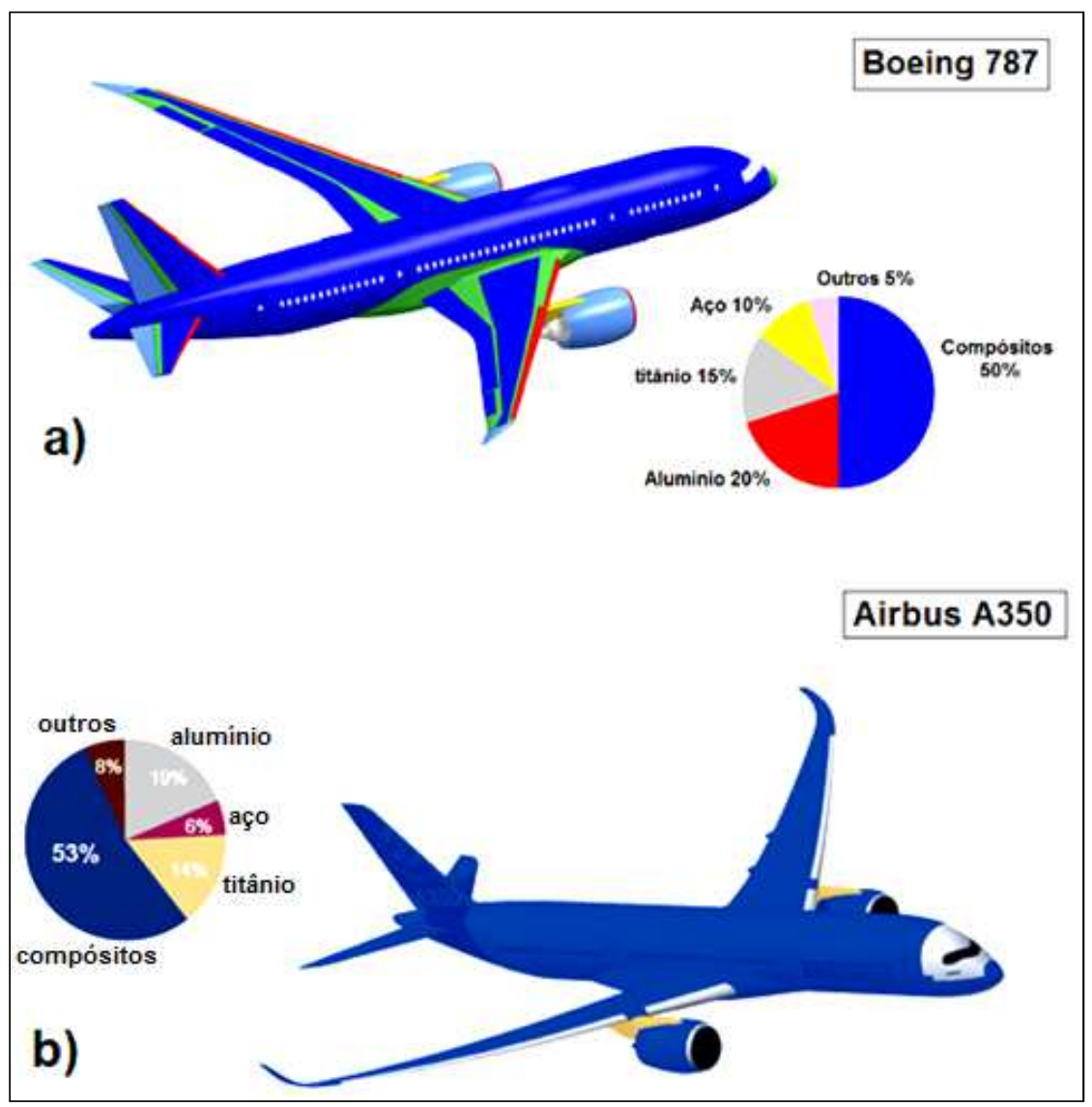

Figura 1.8 - Porcentagem em peso dos materiais de construção empregados nas aeronaves comerciais: (a) 787, e (b) A350 (Adaptados, respectivamente, de http://www.boeing.com/boeing/commercial/787family/787-10prod.page? http://www.a350xwb.com/sensational/shape). 
Segundo a fabricante Boeing, a aplicação de compósitos na fuselagem de sua nova aeronave B787 permitiu o uso de janelas de passageiros $30 \%$ maiores e a utilização de pressão interna equivalente a uma altitude de 6.000 pés, o que representa 2.000 pés a menos do que outros modelos, além da possibilidade de manutenção de um nível superior de umidade no interior da cabine, proporcionando assim mais conforto aos passageiros. Embora aberturas na fuselagem (janelas de passageiros) atuem como concentradores de tensão e uma pressão interna maior na cabine aumentem os esforços exercidos na estrutura, as melhorias acima mencionadas foram possível devido às maiores resistência mecânica e rigidez específica, resistência à fadiga e à corrosão dos compósitos com relação às ligas de alumínio comumente utilizadas em projetos aeronáuticos.

Embora as recentemente desenvolvidas aeronaves civis da Boeing e Airbus tenham porcentagem em peso similar no que diz respeito ao uso de materiais compósitos (essencialmente de matriz polimérica e fibras contínuas de carbono), ambas apresentam importantes diferenças em termos de projeto e de concepção.

Como exemplo, tem-se a questão da fabricação das seções de fuselagem. $\mathrm{Na}$ aeronave B787, as seções foram fabricadas como uma parte "única", através do processo de fabricação denominado "Automated Fiber Placement - AFP", onde a seção inteira é fabricada sobre um mandril giratório e, após a deposição de camadas, a parte é levada para uma autoclave para realização do processo de cura. Como cada seção é fabricada como uma parte única (Figura 1.9), a união entre seções de barril é feita ao longo da circunferência das mesmas por intermédio de fixadores mecânicos.

Já para a fabricação e montagem da fuselagem do A350, a Airbus optou pela utilização de seções formadas pela união de quatro painéis presos por fixadores.

Confrontando-se os dois projetos, pode-se inferir que o do B787 apresenta uma concepção otimizada sob o ponto de vista de juntas (união de estruturas), pois como as seções são fabricadas como partes únicas, as juntas só aparecem na união das seções umas com as outras. No entanto, para a sua aeronave A350, a Airbus afirma que seu projeto de seções de fuselagem formadas pela união de painéis apresenta como vantagem a possibilidade de se fabricarem painéis otimizados em função dos esforços a que estes estarão submetidos em serviço (Figura 1.10). A substituição imediata do painel, no caso de grandes danos que venham a ocorrer durante a 
operação da aeronave, além da possibilidade de unir a seção central (local submetido a grandes esforços mecânicos solicitantes devido à união com as asas) às seções adjacentes em áreas de menores níveis de carregamentos, são grandes atrativos no que se refere à etapa de manutenção da aeronave.

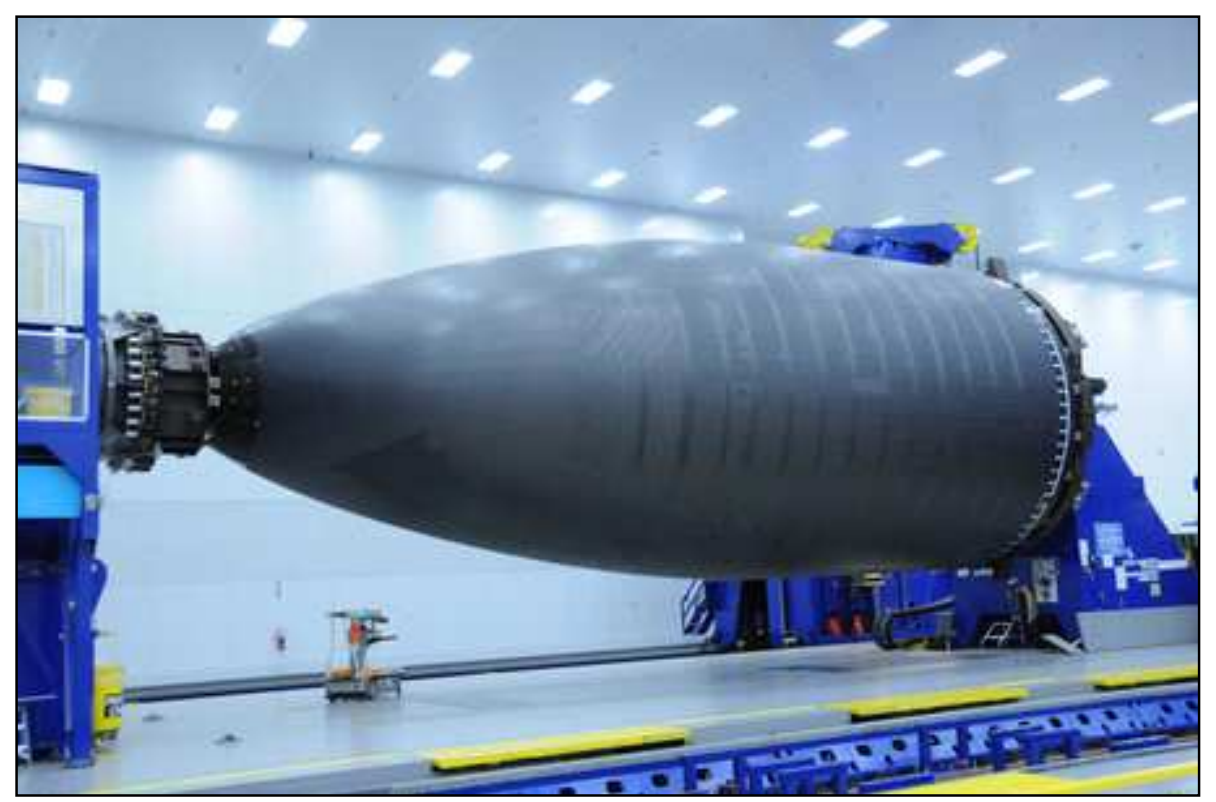

Figura 1.9 - Seção dianteira da fuselagem do Boeing 787 durante a fabricação (Adaptado de http://www.cnet.com/pictures/in-kansas-where-787-dreamliners-are-born-pictures/).

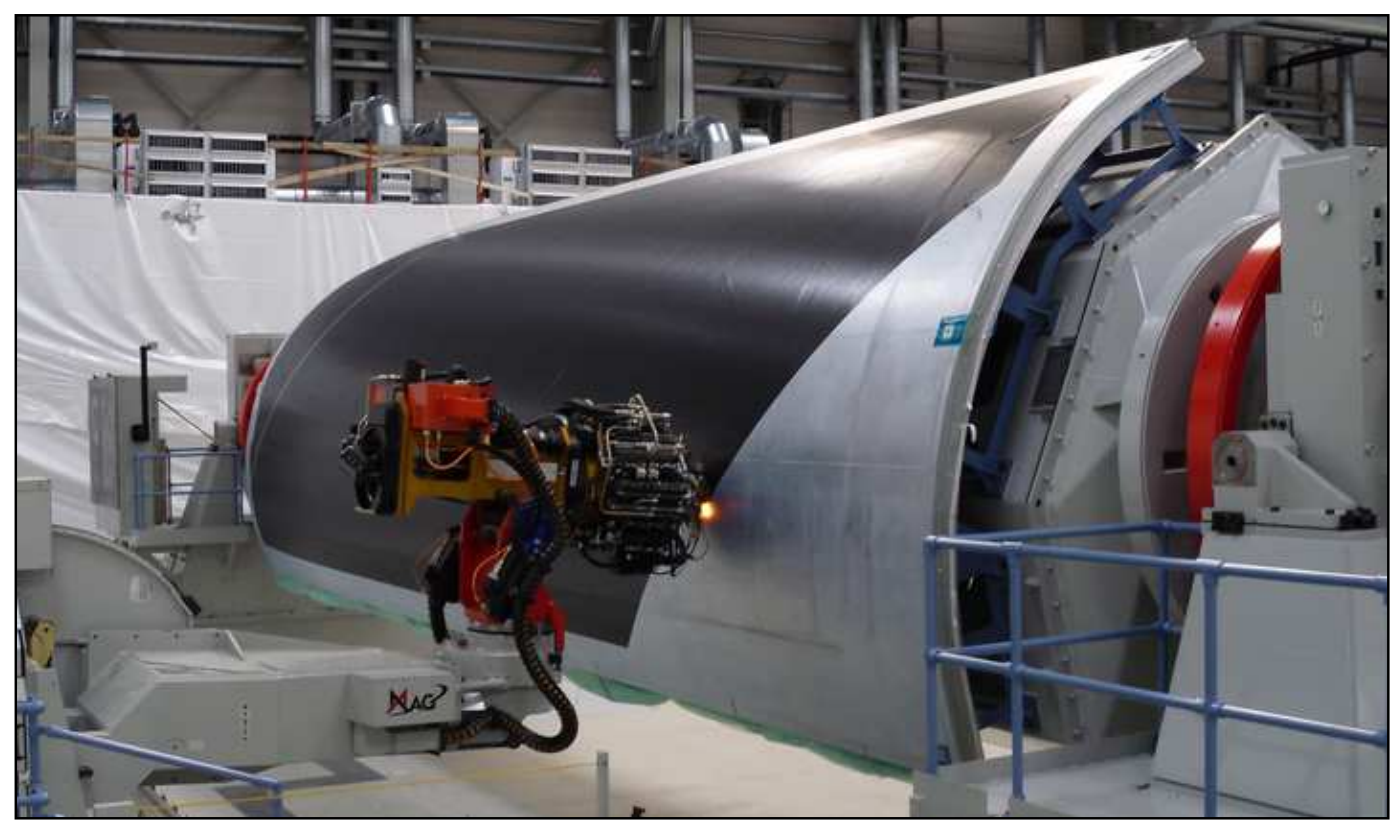

Figura 1.10 - Aeronave Airbus A350, painel de uma das seções; (Adaptado de http://www.premium-aerotec.com/en/Page1516.html) 
A Figura 1.11 ilustra a montagem da fuselagem no Boeing 787 e no Airbus A350. Notase que no projeto do Boeing 787 o número de juntas é menor que no Airbus A350, uma vez que o projeto das seções da fuselagem em "barril" visa justamente o menor número de uniões.

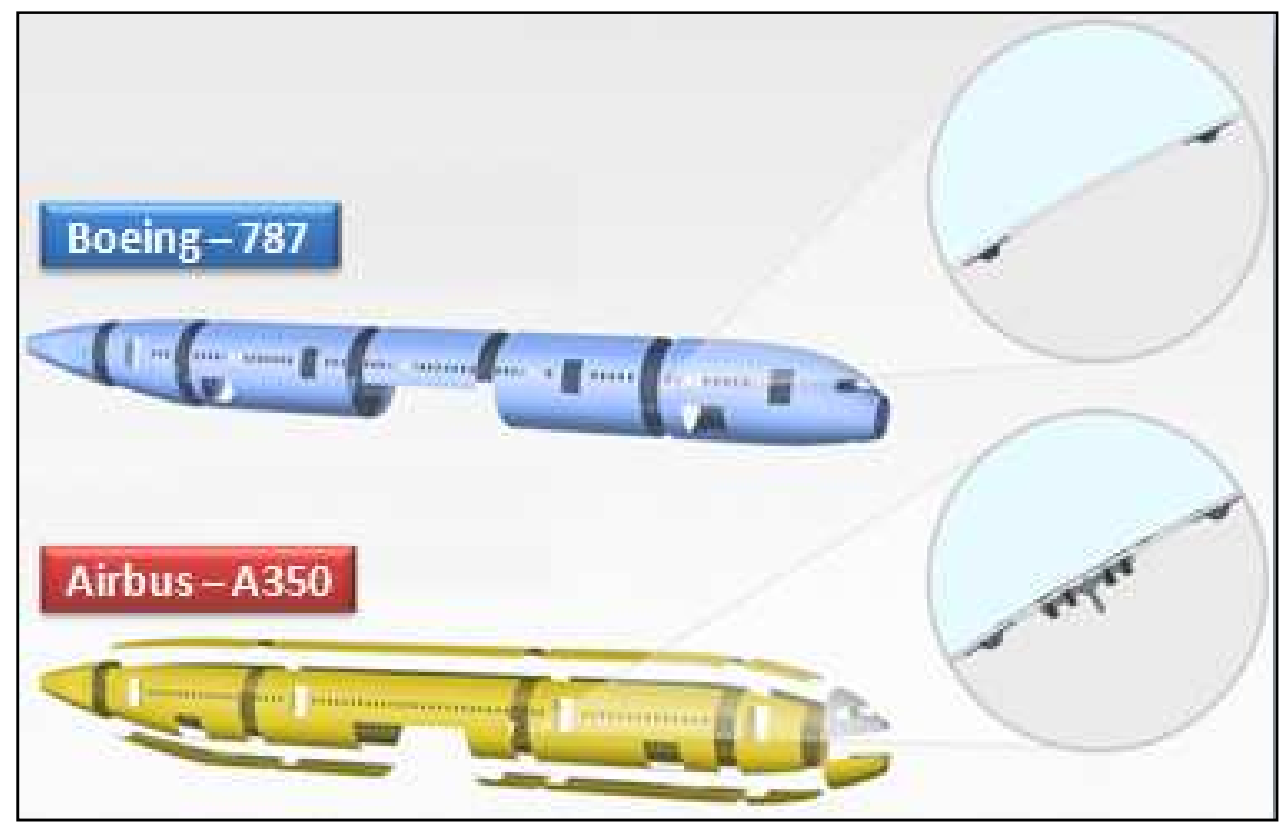

Figura 1.11 - Detalhes da união das seções da fuselagem para o Boeing 787 e o Airbus A350. (Adaptado de http://www.newairplane.com/787/\#/design-highlights/visionarydesign/composites/one-piece-barrel-construction/)

\subsection{Higrotermina e impacto de baixa energia em materiais compósitos laminados}

Estruturas aeronáuticas fabricadas em materiais compósitos laminados estruturais, quando em operação em ambientes higrotérmicos por longos períodos, podem ter seu desempenho mecânico afetada podendo levar a falha prematura da estrutura.

Segundo HULL (1995), materiais compósitos do tipo matriz polimérica reforçado com fibras, quando expostos a condições higrotérmicas podem causar profundas alterações em suas propriedades mecânicas. Essas alterações podem ser mais bem entendidas quando analisadas para cada constituinte individualmente, ou seja, a matriz, a interface e as fibras. 
$\mathrm{Na}$ matriz, o efeito sobre suas propriedades mecânicas é devido à difusão de umidade no polímero que pode causar sua flexibilização, assim como, afetar a resistência a compressão e ao cisalhamento interlaminar e intralaminar do compósito, uma vez que essas propriedades são governadas pela matriz.

A interface matriz-reforço pode ser afetada pela difusão da umidade por capilaridade na matriz ocasionando a nucleação e o crescimento de trincas. Já para as fibras, estas em geral não são afetadas, uma vez que a matriz as protege do ambiente.

Outro fator que pode afetar o desempenho de materiais compósitos estruturais é o carregamento por impacto de baixa energia. Neste caso, na face que sofre o impacto, após uma rápida inspeção visual, é possível observar apenas uma pequena identação. No entanto, no interior do laminado, o impacto pode causar trincas e dalaminações ocasionando significativas perdas das propriedades mecânicas do compósito (POLIMENO e MEO, 2009).

Deste modo, a compreensão dos efeitos acima citados nos compósitos laminados estruturais são de extrema importância para que possa-se prever seu comportamento em situações reais de operação, ou seja, quando aplicados na fabricação de estruturas aeronáuticas.

\subsection{Motivação}

Como anteriormente citado, o uso crescente de materiais compósitos na aplicação de estruturas primárias de aeronaves comerciais tem elevado o número de estudos que visam prever o comportamento destes materiais em serviço, especialmente sob condições adversas, como por exemplo, seu desempenho em ambientes com alta temperatura e umidade e quando submetidos a impactos de baixa energia.

Nesse contexto, este trabalho tem como proposta contribuir para o entendimento do comportamento mecânico de laminados compósitos estruturais submetidos às condições acima citadas, mediante a avaliação de duas juntas concorrentes sob as mesmas condições de carregamento. 


\subsection{Objetivos}

Dentre as múltiplas possibilidades de aplicação de uma grande variedade de laminados compósitos fibrosos e métodos de união dos mesmos em estruturas aeronáuticas, este trabalho tem por objetivos: (i) estudar e confrontar o desempenho mecânico de juntas soldadas e coladas de laminados compósitos reforçados com fibras contínuas de carbono e matrizes termoplástica e termorrígida, respectivamente, após uma série de tratamentos de degradação mecânica e higrotérmica das mesmas, (ii) avaliar a qualidade dos processos de manufatura das juntas, e (iii) caracterizar os modos de falha predominantes nas mesmas nas suas várias condições de degradação prévia,

Na seqüência são descriminadas de modo mais detalhado as tarefas envolvidas na busca dos objetivos acima elencados:

- Caracterização mecânica original, processos de degradação mecânica e higrotérmica das juntas e propriedades mecânicas residuais das juntas:

- Ensaio quase-estático de flexão em quatro pontos para determinação das propriedades originais das juntas soldada termoplástica e colada termorrígida;

- Carregamento sob impacto transversal, condicionamento higrotérmico e carregamento em fadiga compressiva das juntas visando à degradação das mesmas;

- Ensaio quase-estático de flexão em quatro pontos para determinação das propriedades residuais das juntas soldada termoplástica e colada termorrígida previamente degradadas.

- Análise fratográfica das juntas como-manufaturados e danificadas:

- Análise das superfícies de fratura via inspeção visual, estereoscopia e microscopia eletrônica de varredura (MEV); 
- Avaliar a qualidade dos processos de manufatura das juntas:

- Através do ensaio de cisalhamento interlaminar (ILSS) para amostras retiradas da área de união dos dois tipos de juntas estudadas.

- Microscopia óptica de seções transversais e longitudinais removidas de amostras virgens e impactadas.

\subsection{Organização do Texto}

No Capítulo 1, "Introdução", realizou-se uma breve apresentação sobre materiais compósitos poliméricos fibrosos estruturais e suas aplicações na área de construção aeronáutica. Foram definidos os objetivos básicos do presente projeto de pesquisa em nível de Mestrado.

No Capítulo 2, "Revisão Bibliográfica", é apresentada uma revisão aprofundada dos tipos de juntas mais comumente empregadas nas aplicações envolvendo o uso de laminados compósitos poliméricos fibrosos, que são as juntas mecânicas (unidas por fixadores), as juntas coladas e as juntas soldadas.

No Capítulo 3, "Materiais e Métodos", descrevem-se os materiais e as classes de juntas utilizadas no presente trabalho, assim como os tratamentos de degradação mecânica e ambiental das juntas, bem como os ensaios mecânicos realizados e as análises microscópicas e fratográficas efetuadas nas mesmas.

No Capítulo 4, "Resultados e Discussões", apresentam-se e discutem-se os resultados obtidos com relação aos processos de degradação das juntas, assim como relativamente à caracterização mecânica em flexão das mesmas nas condições de, respectivamente como manufaturadas e degradadas, bem como quanto às análises de falha para todas as possíveis condições investigadas.

No Capítulo 5, "Principais Conclusões", apresentam-se de modo objetivo, conciso, mas completo, os resultados mais expressivos do trabalho, onde se tenta satisfazer os objetivos traçados originalmente, fechando-se assim o ciclo do trabalho proposto. 
No Capítulo 6, "Sugestões para Trabalhos Futuros", apresentam-se possibilidades de ensaios complementares e suplementares de modo a expandir o escopo da presente dissertação;

No Capítulo 7, "Referências Bibliográficas", listam-se todas as referências bibliográficas consultadas para a elaboração e o desenvolvimento desta Dissertação de Mestrado.

Em Apêndices são fornecidos dados na forma de gráficos e tabelas para eventual consulta do leitor. 


\section{REVISÃO BIBLIOGRÁFICA}

Objetiva-se por intermédio desta revisão da literatura fornecer ao leitor o estado da arte nas seguintes especialidades relacionadas às juntas de materiais compósitos de matriz polimérica (termoplástica ou termorrígida) reforçada por fibras contínuas de alto desempenho mecânico:

* Juntas termorrígidas coladas;

* Juntas termoplásticas soldadas;

- Mecanismos de falha;

* Efeitos de variáveis extrínsecas no desempenho mecânico de juntas.

* Normas técnicas da American Society for Testing and Materials;

\subsection{Juntas em Materiais Compósitos}

No universo da indústria aeronáutica, a estrutura completa de uma aeronave é composta de várias partes tais como revestimentos, nervuras, quadros, reforçadores, longarinas, etc., as quais podem ser unidas por fixadores, coladas ou soldadas (NIU, 1992). Fatores como a facilidade de desmontar, inspecionar, reparar ou substituir partes da estrutura devem ser levados em conta no momento de decidir sobre o método de junção a ser utilizado.

Para se extrair todo o potencial do uso dos materiais compósitos de matriz polimérica reforçados com fibras contínuas de alto desempenho mecânico na redução do peso estrutural da aeronave, os tipos de esforços a que a junção estará submetida em condições reais de serviço deverão também ser considerados no momento da escolha do método de fabricação. Junções mal projetadas estarão sujeitas à concentração de tensões, momentos secundários e deflexões excessivas. Nos compósitos poliméricos de grau aeronáutico, esses problemas são críticos 
devido à alta resistência mecânica e rigidez específica e ao comportamento de natureza essencialmente frágil dos mesmos, ou seja, à incapacidade do material se deformar permanentemente em alguma extensão impede a redistribuição de tensão na área da junção quando esta é submetida a um determinado carregamento, mesmo no caso de matrizes poliméricas termoplásticas.

$\mathrm{Na}$ indústria aeronáutica, a complexidade das estruturas requer ótimo custobenefício e métodos confiáveis de união. Os métodos clássicos de união de laminados compósitos termorrígidos entre si, ou vinculados a ligas metálicas (as chamadas juntas mistas, heterogêneas ou dissimilares) são de natureza mecânica (união por prendedores ou fixadores: parafusos, rebites, pinos e "hi-locks") ou adesiva (colagem), ou mesmo, o emprego simultâneo das duas metodologias. Juntas mecânicas apresentam desvantagens tais como a necessidade de introduzirem furos na junta, os quais induzem concentração de tensão, e a instalação de fixadores que adicionam custo e peso à estrutura (CHAZERAIN, 2009). As juntas coladas proporcionam uma distribuição uniforme de tensão na área de união, comparadas às juntas mecânicas. No entanto, as juntas coladas requerem uma melhor preparação da superfície, uma tarefa que pode ser complexa e consumir muito tempo. No caso particular dos compósitos de matriz termoplástica reforçados com fibras contínuas, a soldagem por fusão aparece como uma alternativa natural para o caso de juntas em estruturas aeronáuticas.

\subsection{Juntas Coladas}

As juntas coladas apresentam, na área de junção, uma distribuição de tensão mais uniforme do que as juntas mecânicas, eliminando a concentração de tensão gerada pelo uso de fixadores (Figura 2.1), obtendo-se assim vidas mais longas em fadiga. Juntas coladas apresentam também melhor capacidade de amortecimento de vibrações (CAMPBELL, 2006).

A não utilização de fixadores também auxilia na manufatura de estruturas mais leves, um melhor acabamento externo e também aumentam a rigidez global comparativamente as estruturas compósitas parafusadas. 
Nas juntas coladas, a transferência de carga entre o laminado e o adesivo deve ocorrer por cisalhamento, e a eficiência de transmissão das tensões depende principalmente da resistência a este tipo de esforço por parte do adesivo utilizado e da qualidade da união entre adesivo/aderente durante a fabricação.
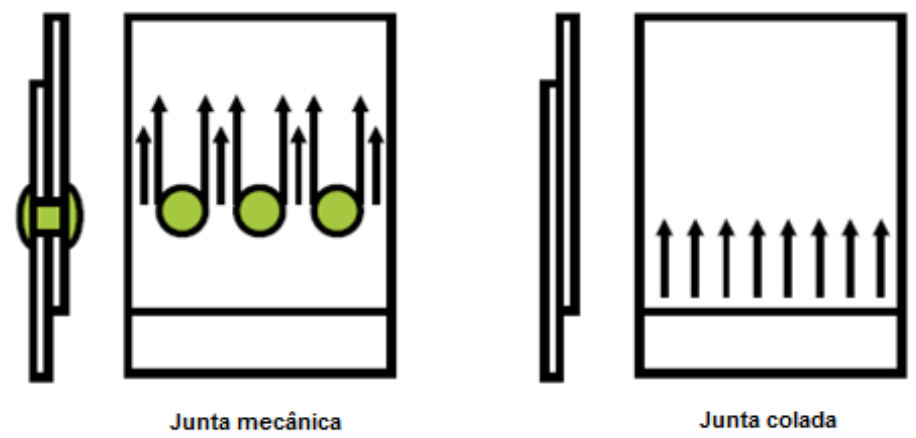

Figura 2.1 - Distribuição da tensão ao redor dos furos e no adesivo em, respectivamente, juntas mecânicas e coladas (Adaptado de CAMPBEL, 2006).

Para avaliar a resistência de uniões em estruturas aeronáuticas de laminados compósitos, a junta sobreposta simples ("single lap joint") é muito utilizada por ser de fácil fabricação e por apresentar relativamente baixo custo. Contudo, devido ao fato de este tipo de junta não apresentar simetria em relação ao eixo ou plano de carregamento em tração, ele apresenta um estado complexo de tensões na área colada (Figura 2.2).

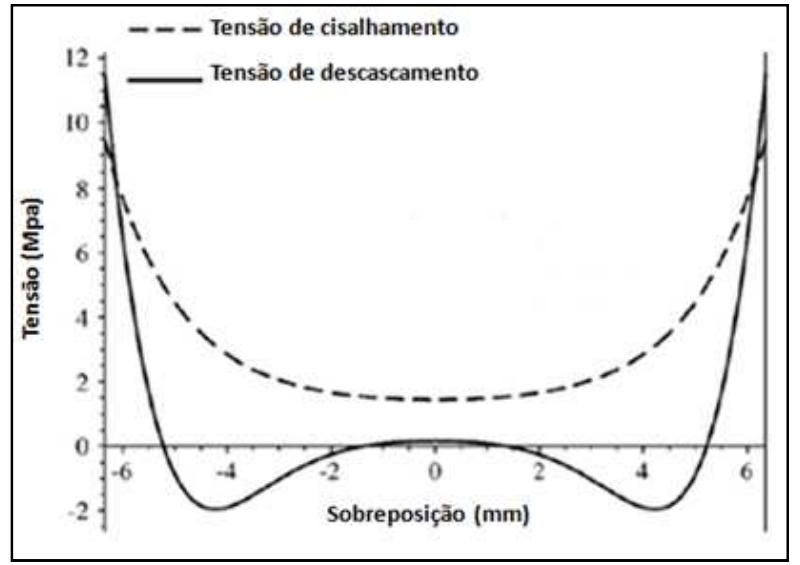

Figura 2.2 - Perfis típicos das tensões de cisalhamento ("shear stress") e de descascamento trativo ("peel stress") desenvolvidos em uma junta do tipo cisalhante sobreposta simples ("single lap joint") quando esta é macroscopicamente solicitada em tração (Adaptado de SILVA et al., 2009). 
Além da transmissão de esforços que ocorre por cisalhamento entre o aderente (laminado) e o adesivo, a assimetria faz com que esta configuração apresente momento secundário, o qual provoca $\circ$ aparecimento de tensões transversais, denominadas na literatura por "peel stress" e já indicadas na Figura 2.2, as quais se desenvolvem nas bordas livres da junta, propiciando assim o aparecimento de trincas e delaminações na interface adesivo/aderente (Figura 2.3).

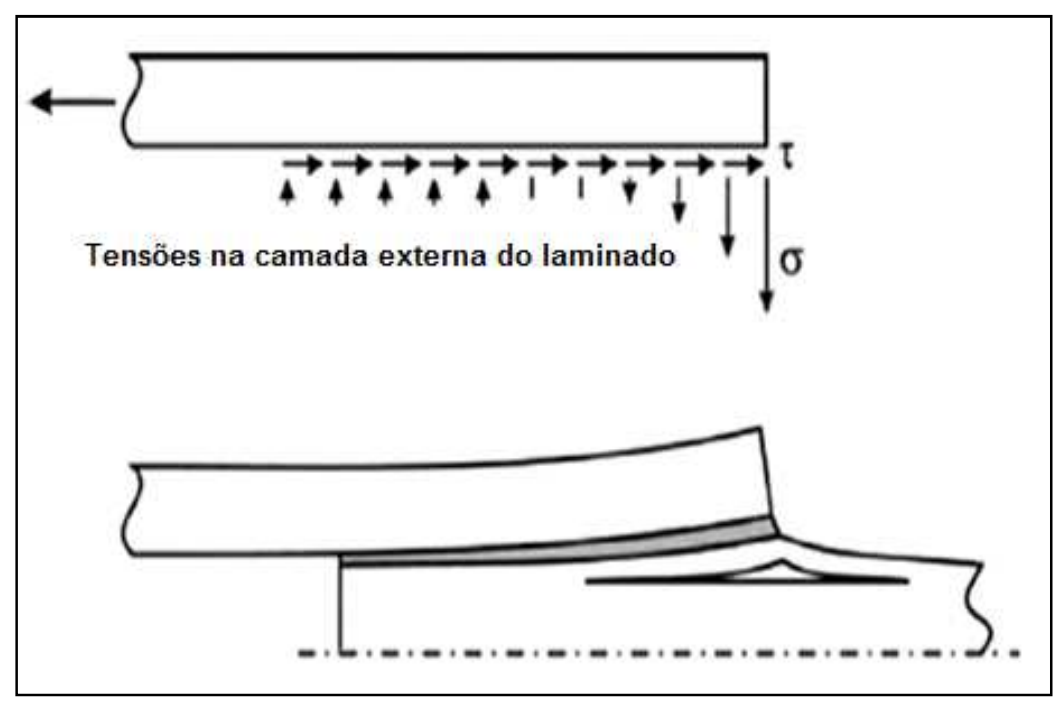

Figura 2.3 - Pico de tensão transversal ou de descascamento trativo ("peel stress") desenvolvido na borda livre da junta de cisalhamento sobreposta simples (Adaptado de BANEA \& da SILVA, 2009).

\subsubsection{Tipos de juntas coladas}

Na Figura 2.4 CAMPBELL (2006) ilustra os tipos mais comuns de juntas coladas aplicadas na união de aderentes compósitos. Como discutido anteriormente, a transmissão dos esforços do aderente para o adesivo acontece via cisalhamento. Contudo, a Figura 2.2 mostra que este cisalhamento não é uniforme ao longo da área de contato entre 0 adesivo e o aderente. A tensão de cisalhamento máxima ocorre nas bordas livres da junta e decresce em direção ao centro. 


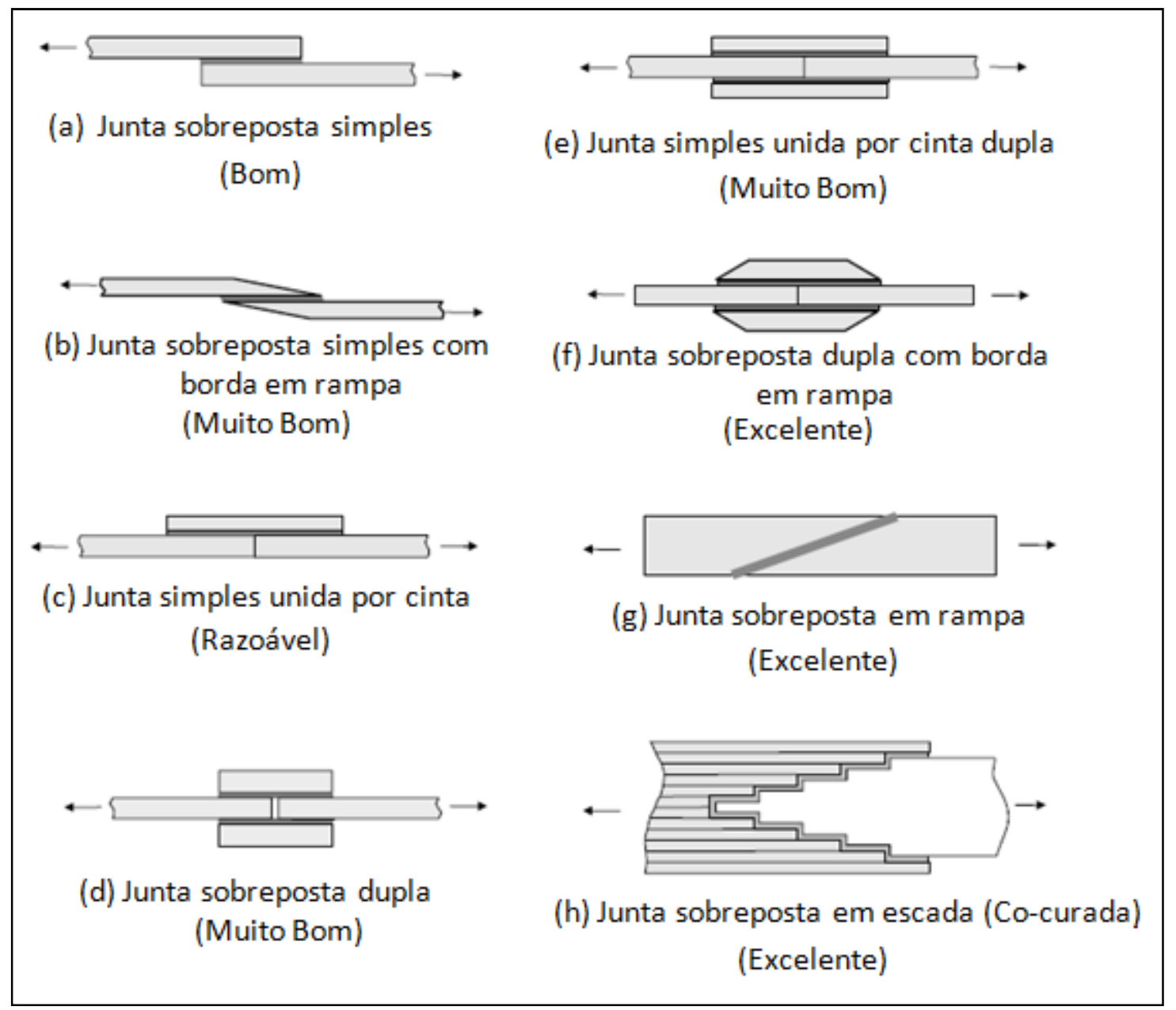

Figura 2.4 - Tipos mais comuns de juntas aplicadas a laminados compósitos sólidos (Adaptado de CAMPBELL, 2006).

Para minimizar o efeito da concentração de tensão nas bordas livres da junta, RAPHAEL (1966) propôs usar adesivos com módulos de resistências diferentes ao longo da junção. Adesivos com alto módulo (exibindo comportamento mais frágil) desenvolvem concentração de tensão nas bordas, mas essa concentração de tensão poderia ser reduzida aplicando-se nesta região da junta adesivos com baixo módulo (mais flexíveis, e apresentando comportamento mais dúctil), conforme indica a Figura 2.5.

Com base no raciocínio acima, RAPHAEL (1966) propôs o emprego do adesivo dúctil (baixo módulo) nas bordas da junta e do adesivo frágil (alto módulo) na porção central da mesma, conforme ilustrado na Figura 2.6. Dessa maneira, o adesivo flexível, embora menos resistente, apresenta maior capacidade de deformação, ficando localizado nas áreas que sofrem maior deformação (bordas), enquanto que o 
adesivo rígido, localizado na região central, onde a deformação é menor, suporta a maior parte do cisalhamento. Considerando a distribuição de tensão, a máxima tensão de cisalhamento no adesivo rígido será, portanto, menor do que se este adesivo fosse aplicado em toda a área de colagem.

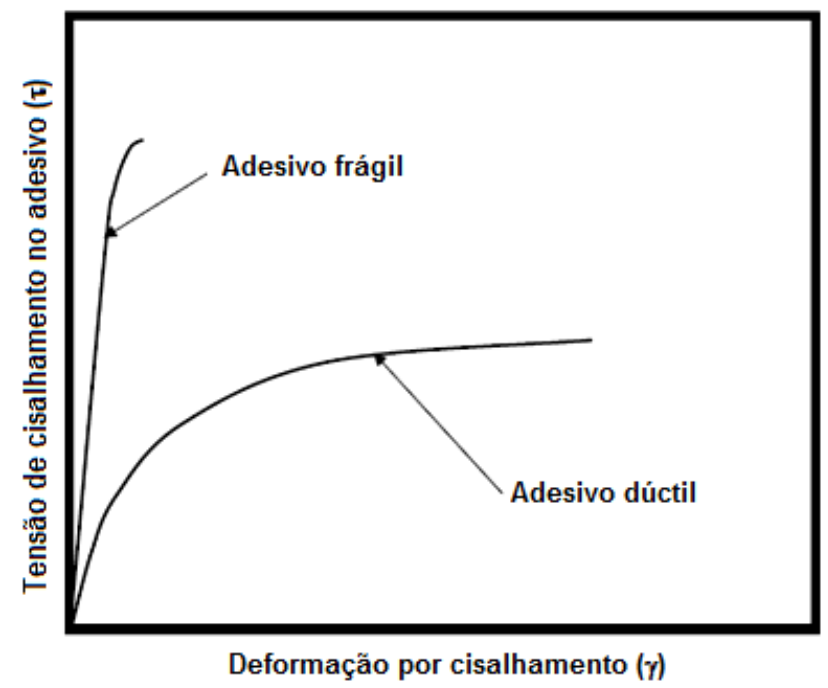

Figura 2.5 - Representação do comportamento de um adesivo frágil e outro dúctil quando aplicados em junta colada submetida à tração (Adaptado de RAPHAEL, 1966).

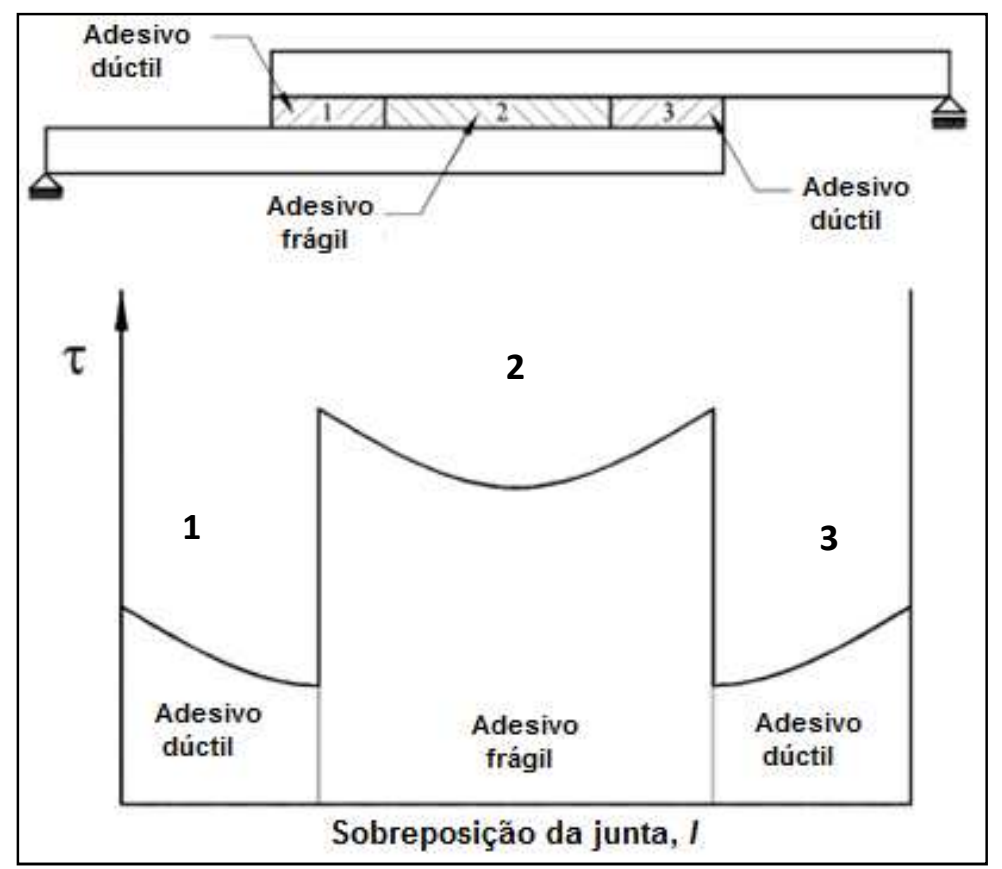

Figura 2.6 - Distribuição da tensão de cisalhamento ao longo do comprimento da face colada (Adaptado de RAPHAEL, 1966). 
ZENG \& SUN (2003) avaliaram uma junta do tipo sobreposta simples, mas com geometria modificada na área de colagem, a qual denominaram ondulada "wavy", como mostra a Figura 2.7. Ao analisar via elementos finitos com um modelo nãolinear em 2D, obtiveram as correspondentes curvas de distribuição das tensões de cisalhamento e de descascamento ao longo do adesivo, comparativamente à junta convencional do tipo sobreposta simples. A Figura 2.8 compara as curvas obtidas.

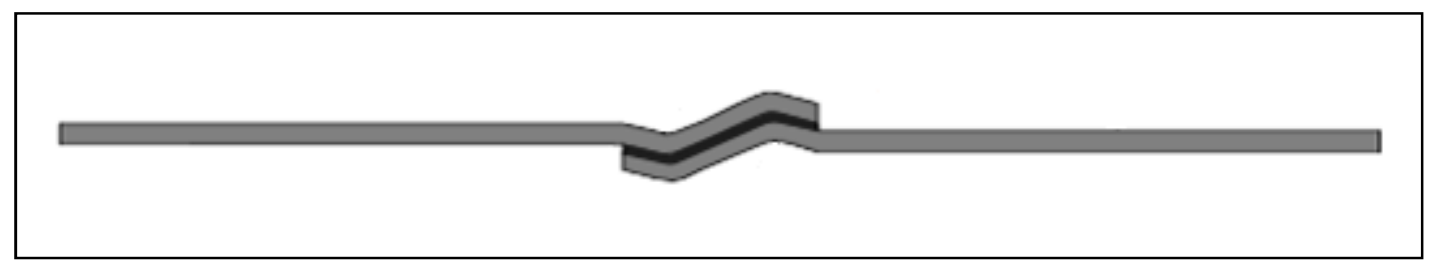

Figura 2.7 - Modificação de junta denominada ondulada ("wavy") (Adaptado de ZENG \& SUN, 2003).

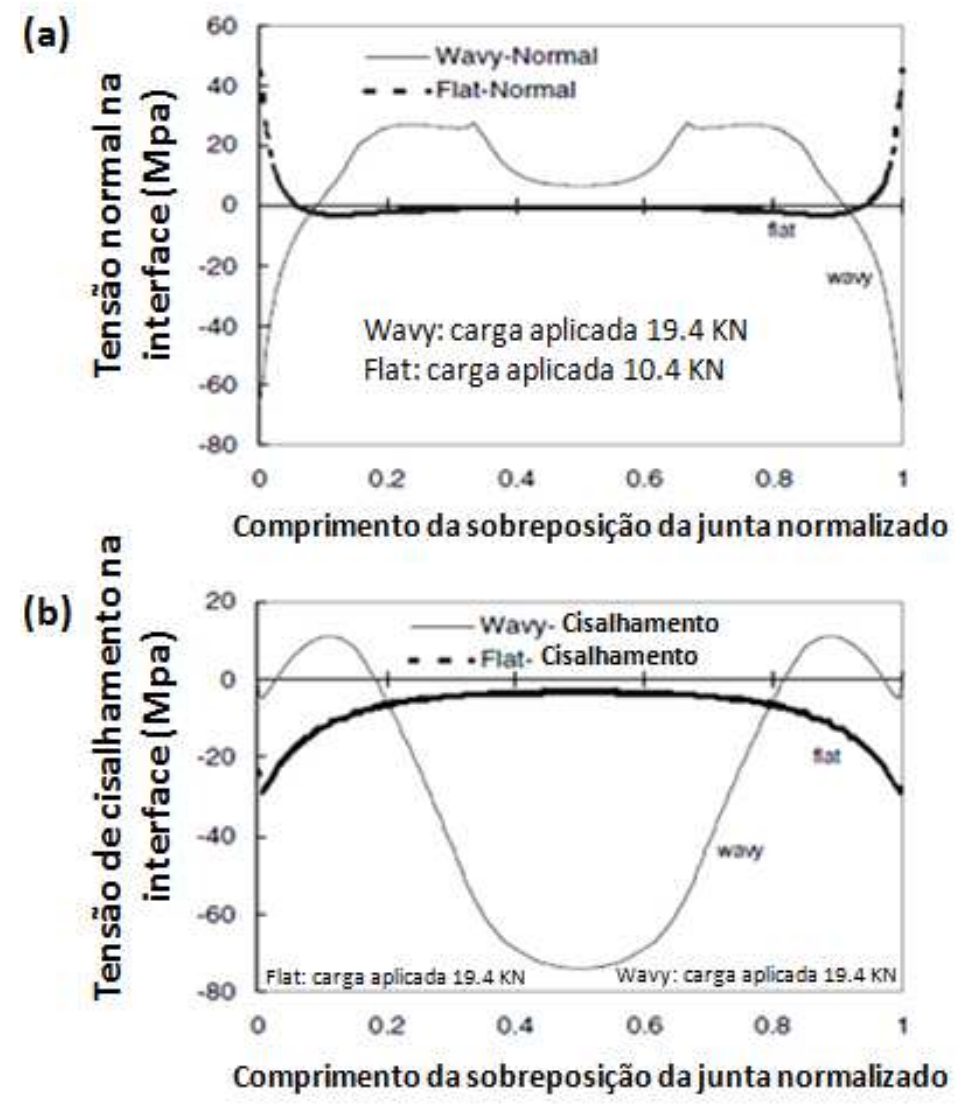

Figura 2.8 - Comparativo da distribuição das tensões de descascamento (a), e de cisalhamento (b) ao longo do adesivo para as juntas do tipo "wavy" sobreposta simples (Adaptado de ZENG \& SUN, 2003). 
Observa-se que ZENG \& SUN (2003) obtiveram tensão compressiva nas bordas livres para a junta do tipo "wavy", ou seja, eliminaram a tensão trativa nas bordas livres, a qual constitui um sério problema para a configuração do tipo junta sobreposta simples. A distribuição de cisalhamento no adesivo da junta do tipo "wavy" tem maior concentração no meio da área colada, aliviando assim o pico de tensão nas bordas livres da junta em relação à junta sobreposta simples.

\subsubsection{Influência da espessura do laminado no desempenho da junta}

Juntas coladas são usadas em metais e materiais compósitos. Contudo, para os materiais compósitos a colagem de juntas traz implicações as quais não são observadas em metais. Devido ao caráter anisotrópico (de fato, ortotrópico) dos laminados compósitos reforçados com fibras contínuas, estes possuem baixa resistência interlaminar e baixa resistência ao cisalhamento, pois, no caso dos compósitos com matriz polimérica, o cisalhamento é suportado por esta última que, em geral, possui baixa resistência mecânica.

A Figura 2.9 mostra os tipos de juntas coladas aplicadas em junções estruturais, e como a espessura influencia no modo de falha destas. Observa-se que a junta do tipo sobreposta simples ("single lap joint") aparece como a de menor resistência, e a falha desta junta ocorre devido ao momento secundário gerado pela excentricidade do carregamento provocando concentração de tensão transversal ou de descascamento ("peel stress") nas bordas da junta.

Ao se utilizarem aderentes com maior espessura, aumenta-se a excentricidade do carregamento e, proporcionalmente, incrementa-se o momento secundário, 0 que, por fim, diminui significativamente o desempenho mecânico da junta para uma mesma área de colagem.

Conseqüentemente, para aderentes mais espessos, outras configurações de juntas são indicadas. Nota-se que, para a junta do tipo "double-lap joint", embora ela apresente simetria geométrica, o problema da "peel stress" ainda governa o modo de falha da junta, não obstante seu efeito seja significativamente menor que na junta 
"single lap" (LEE et al., 2008). Para mitigar o problema de "peel stress" da junta "double-lap joint", emprega-se a técnica de redução progressiva da espessura dos aderentes superior e inferior na medida em que se afasta do centro da junta, ao longo do comprimento da mesma ("tapering") de modo a alterar o modo de falha da junta (deslocando o modo predominante de falha por descascamento - "peel stress" para cisalhamento) e obter-se resistências muito superiores à geometria convencional ("non-tapered").

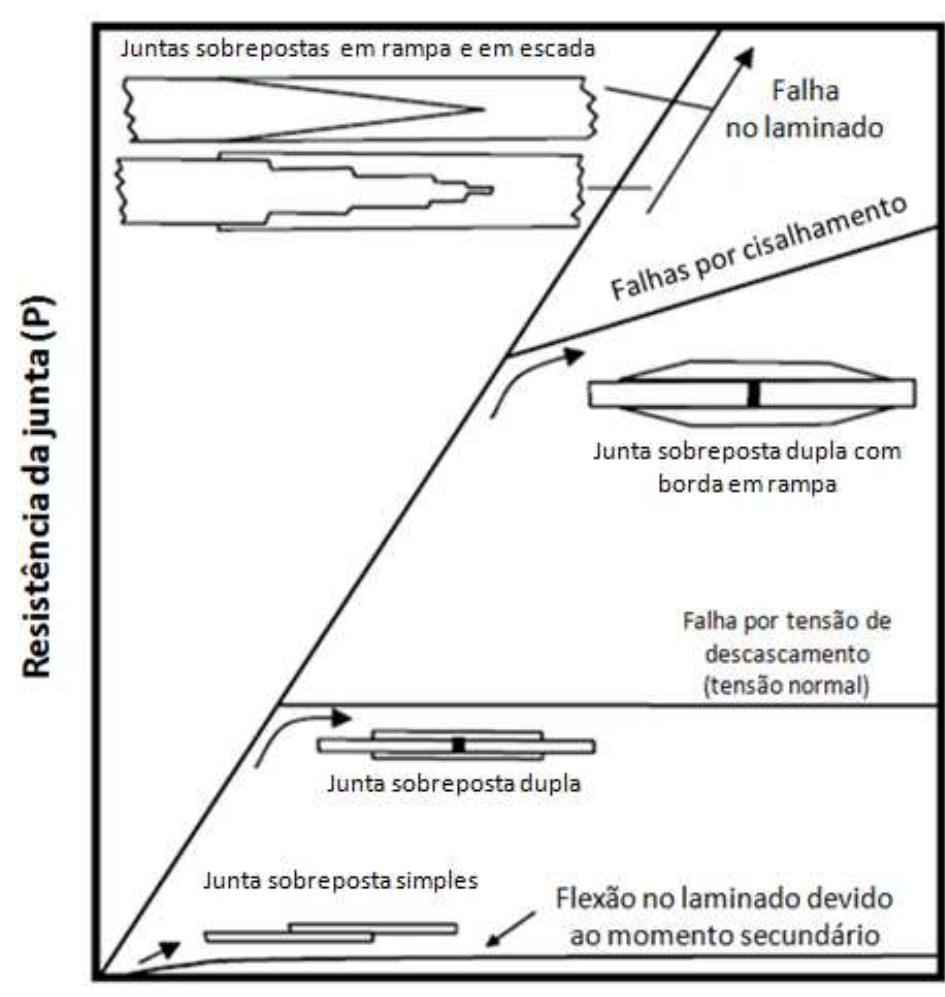

Espessura do laminado $(t)$

Figura 2.9 - Efeito da espessura do aderente no modo de falha da junta colada (Adaptado de CAMPBELL, 2006).

Para aderentes com espessura elevada, os tipos de juntas em rampa ("scarf") e em escada ("step lap joint") são os mais recomendados. A junta do tipo "scarf" é a melhor, pois não apresenta concentradores de tensão nas bordas e possui melhor distribuição do cisalhamento no adesivo (KIM et at., 2005). Acontece que, por ser mais difícil de fabricar, a junta do tipo "scarf" algumas vezes é preterida e substituída pela junta do tipo "step lap joint", cuja fabricação é mais simples e com propriedades mecânicas similares a do tipo "scarf'. 


\subsubsection{Modos de falha}

Os modos de falha das juntas coladas são determinados pela qualidade da adesão do elemento adesivo na interface do aderente, geometria da junta e tipo de carregamento. Após a ruptura, a superfície de fratura deve ser caracterizada para se compreender as propriedades do adesivo e da junta como um todo (BANEA \& da SILVA, 2009). Para juntas de matriz polimérica reforçadas com fibras contínuas, de acordo com a norma ASTM-D5573 (2002) existem sete característicos modos de falha. Os três modos de falha mais comuns são ilustrados na Figura 2.10, sendo eles o interfacial (ou adesivo), o coesivo e o interlaminar. Nota-se pela figura que a falha interfacial/adesiva ocorre na interface adesivo-aderente, a coesiva ocorre no próprio adesivo e a interlaminar ocorre no aderente.

$\mathrm{Na}$ literatura existem muitos trabalhos experimentais que investigaram a influência de vários parâmetros no comportamento de falha das juntas coladas. Os resultados desses estudos mostraram que parâmetros tais como as condições superficiais dos aderentes, os filetes de adesivo, a espessura da linha de colagem, a seqüência de empilhamento das camadas individuais dos laminados (aderentes) e as condições ambientais também afetam significativamente o modo de falha da junta.

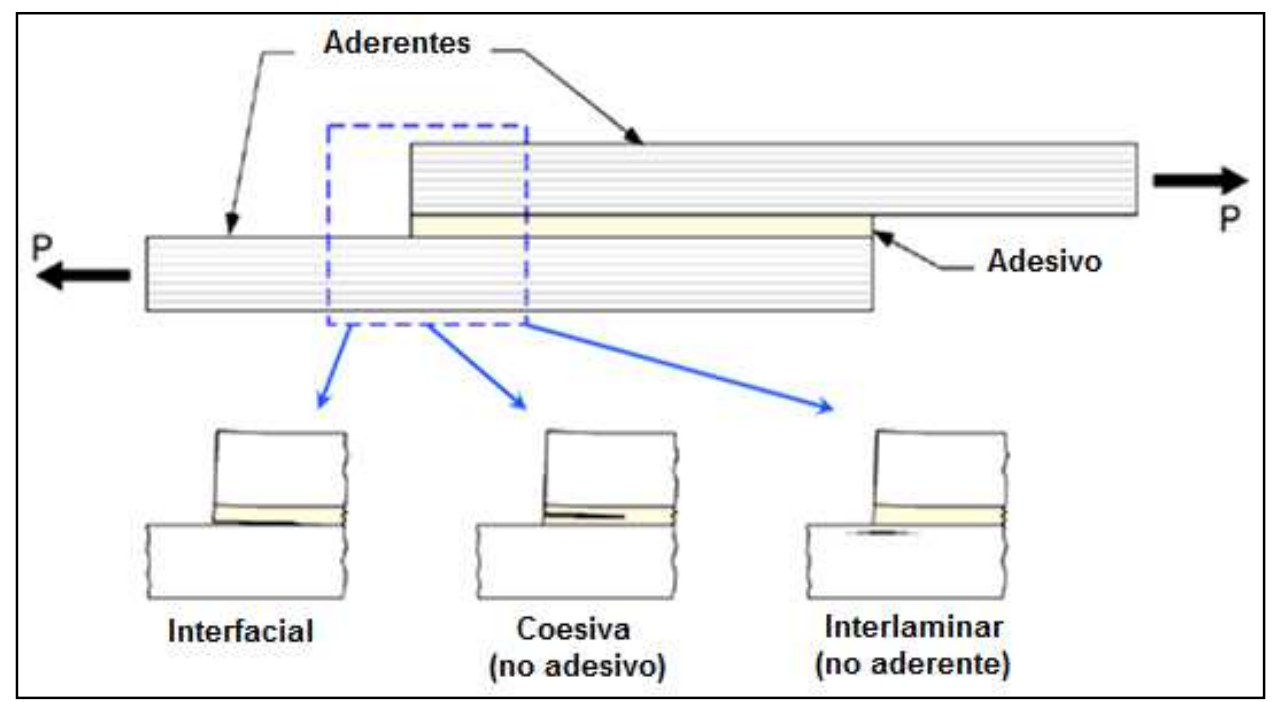

Figura 2.10 - Modos de falha mais comuns para juntas compósitas coladas do tipo cisalhamento simples (Adaptado de ASTM-D5573, 2002). 
Existem também inúmeros estudos relativos à previsão dos modos de falhas de juntas coladas de laminados compósitos fibrosos poliméricos. Contudo, a previsão dos modos de falha para as juntas compósitas ainda é difícil porque a resistência e os modos de falha da junta variam de acordo com o método de colagem usado e dos parâmetros supracitados.

\subsubsection{Aspectos gerais e desempenho de juntas coladas compósitas}

Embora as juntas tenham a função primária de suportar cargas aplicadas no plano ("in-plane loads"), estas estão sujeitas a cargas fora do plano (transversais "out-of-plane"), não só por aspectos geométricos, mas também devido às condições adversas a que as juntas são submetidas durante sua operação em serviço. Em estruturas aeronáuticas, por exemplo, esses carregamentos transversais podem ocorrer devido a colisão com pássaros em vôo ("bird strike"), queda de ferramentas, choque de detritos da pista durante a corrida para a decolagem ou durante o pouso, etc.

VAIDYA et al. (2006) estudaram o efeito de carregamento transversal em juntas coladas de fibra de carbono e resina epóxi aplicando a elas impacto único de baixa velocidade (1 a $2 \mathrm{~m} / \mathrm{s}$ ). Os ensaios foram conduzidos como mostrado na Figura 2.11.

Através de simulações em elementos finitos com modelo em 3D observou-se que cargas normais transversais resultam em maior concentração de "peel stress" quando comparado ao carregamento de tração no plano. Esse aumento do "peel stress" é devido à deflexão sofrida pelas juntas durante o carregamento transversal. Outra importante observação foi quanto à assimetria na distribuição de tensão no adesivo. Diferentemente do que ocorre no carregamento trativo no plano (Fig. 2.2), a "peel stress" variou de tensão trativa na borda do aderente inferior para tensão compressiva na borda do aderente superior (Figura 2.12). Quanto aos ensaios experimentais, todas as juntas apresentaram falha coesiva e tiveram inicio na borda do adesivo submetido à tensão trativa. 


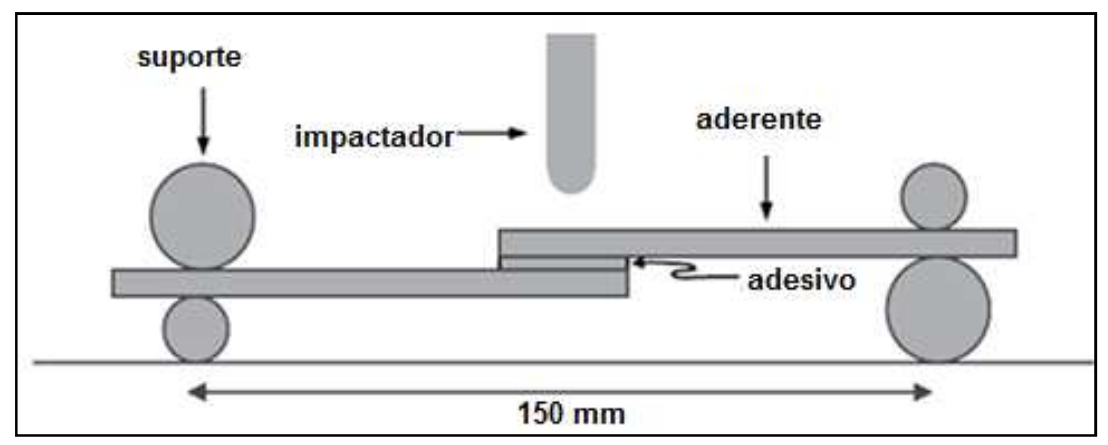

Figura 2.11 - Esquema do dispositivo de ensaio de impacto de baixa velocidade aplicado em juntas coladas sobrepostas simples (Adaptado de VAIDYA et al., 2006).
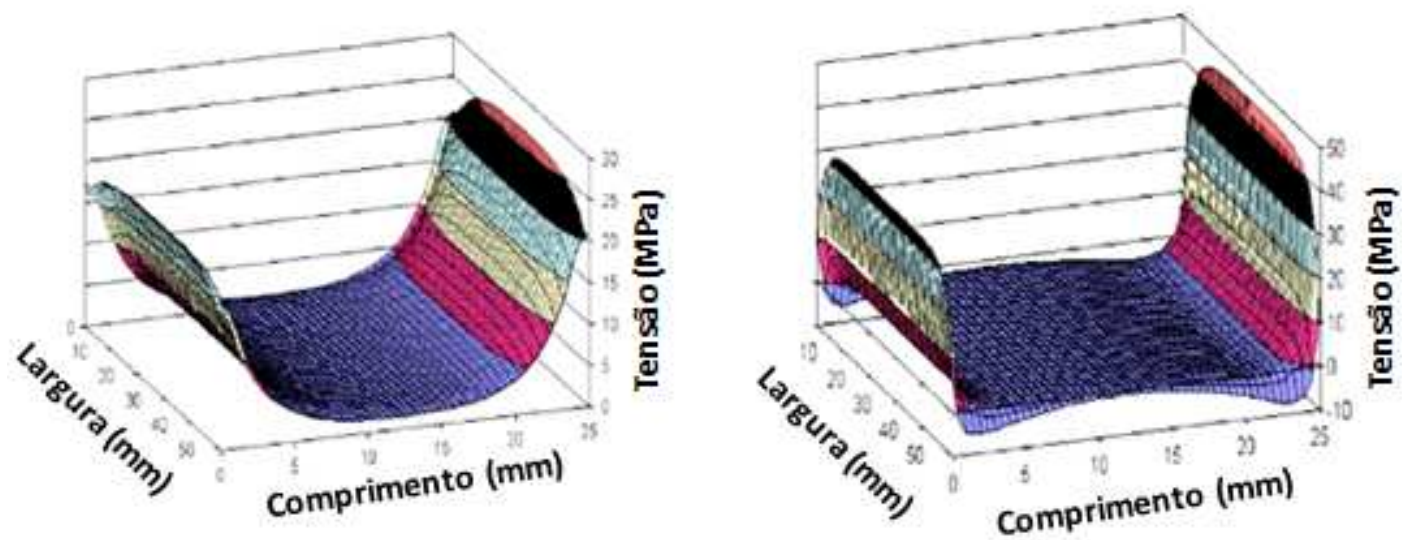

(a)
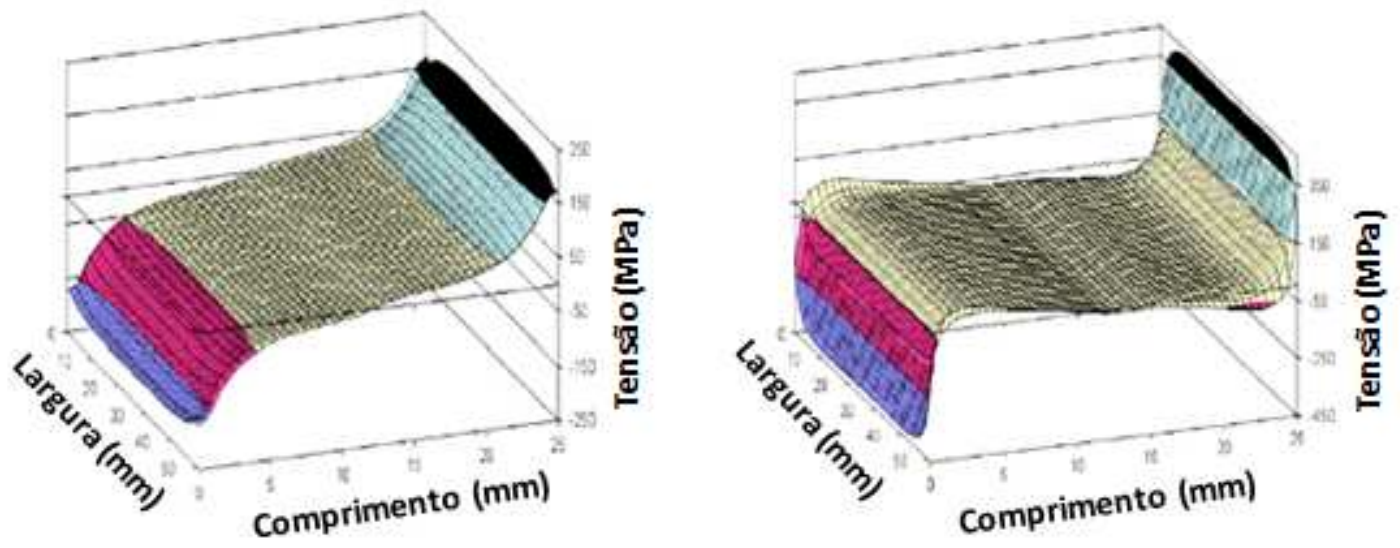

(b)

Figura 2.12 - Comparativo da tensão de cisalhamento e de descascamento para carregamento trativo no plano (a), e transversal fora do plano (b) (Adaptado de VAIDYA et al., 2006).

O desempenho em fadiga de juntas coladas é substancialmente melhor do que o de juntas mecânicas devido à melhor distribuição da tensão ao longo da área de junção (Figura 2.1). Em geral, o desempenho em fadiga dos laminados compósitos fibrosos poliméricos é superior ao dos metais e suas ligas quando submetidos à 
condição de tensão tração-tração. Mas como as estruturas não são carregadas somente em tração, alguns compósitos apresentam baixo desempenho em fadiga sob compressão, cisalhamento e cisalhamento interlaminar pós-impacto.

Em compósitos, trincas na matriz podem aparecer no início da vida em fadiga, com trincas microscópicas existindo na maior parte da vida em fadiga do material.

QUARESIMIN \& RICOTTA (2006) avaliaram o efeito, na vida em fadiga dos espécimes compósitos colados, do comprimento da área adesivada e do filete formado pelo adesivo ao redor da área de contato entre os aderentes confeccionados com fibras contínuas de carbono reforçando uma resina termorrígida epóxi. Observaram que a fração da vida em fadiga correspondente à fase de nucleação de trincas na matriz resinosa variou de $20 \%$ a $70 \%$, dependendo principalmente do comprimento da sobreposição ("overlap") e do nível de tensão aplicado; assim sendo, os pesquisadores enfatizam a importância do desenvolvimento de modelos que melhor descrevam o estagio de nucleação de trincas.

Os pesquisadores constataram também uma grande contribuição da presença de filete na borda livre, pois o aumento da resistência em fadiga foi maior que $25 \%$ em relação à junta sem a presença do filete. Tal comportamento foi justificado pela diminuição da intensidade e do grau de variação da geometria com o filete quando comparado ao desempenho observado para a geometria sem o filete (Figura 2.13).

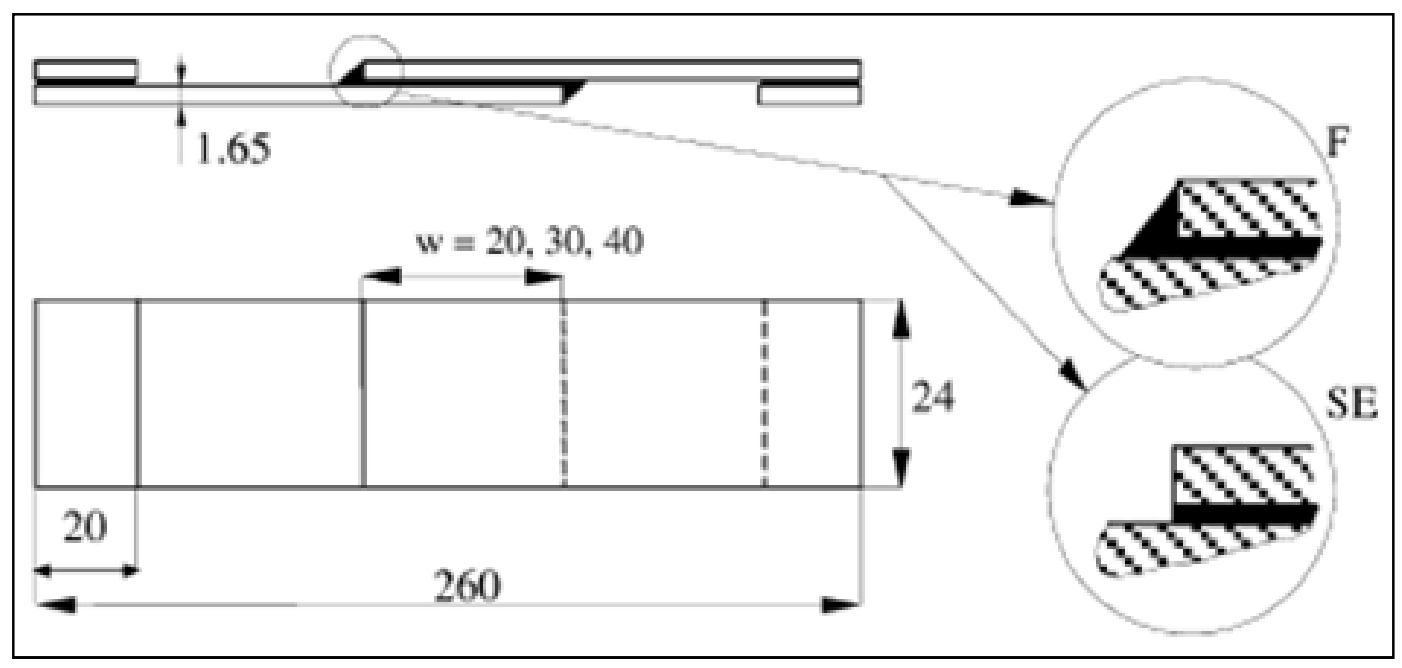

Figura 2.13 - Borda livre da junta com e sem a presença do filete de adesivo além das fronteiras da região de união da junta (Adaptado de QUARESIMIN \& RICOTTA, 2006). 
Com uma junta do tipo "single lap" modificada na área de junção e denominada "wavy" (Figura 2.7), ZENG \& SUN (2003) obtiveram uma melhor distribuição do cisalhamento no adesivo, eliminando assim a tensão trativa nas bordas livres da junta. Com isso, a junta "wavy" exibiu uma vida em fadiga superior a duas vezes aquela da junta "single lap" correspondente.

\subsection{Juntas Soldadas}

As resinas termorrígidas ditas de alto desempenho foram precursoras dos materiais compósitos com matriz polimérica na indústria aeronáutica. Contudo, no final da década de 1980, as resinas termoplásticas passaram a ser introduzidas na manufatura de estruturas compósitas de alto desempenho. Em relação às resinas termorrígidas, os polímeros termoplásticos apresentam maior tolerância a danos, ciclos de processamento mais curtos, são mais resistentes à agressividade ambiental, possuem maior tempo de estocagem, além da possibilidade de reciclagem (AGEORGES et al., 1998; VODICKA, 1996).

Os polímeros termoplásticos possuem grandes massas molares, porém não formam ligações cruzadas no processo de consolidação durante o resfriamento, como as resinas termorrígidas no processo de reticulação (Figura 2.14), o que permite com que sejam processados inúmeras vezes por intermédio da aplicação simultânea de calor e pressão. De fato, esta reconhecida capacidade dos termoplásticos em serem aquecidos até o ponto de fusão (ou de amolecimento, no caso dos polímeros amorfos) e remodelados, permitem que eles sejam soldados. 


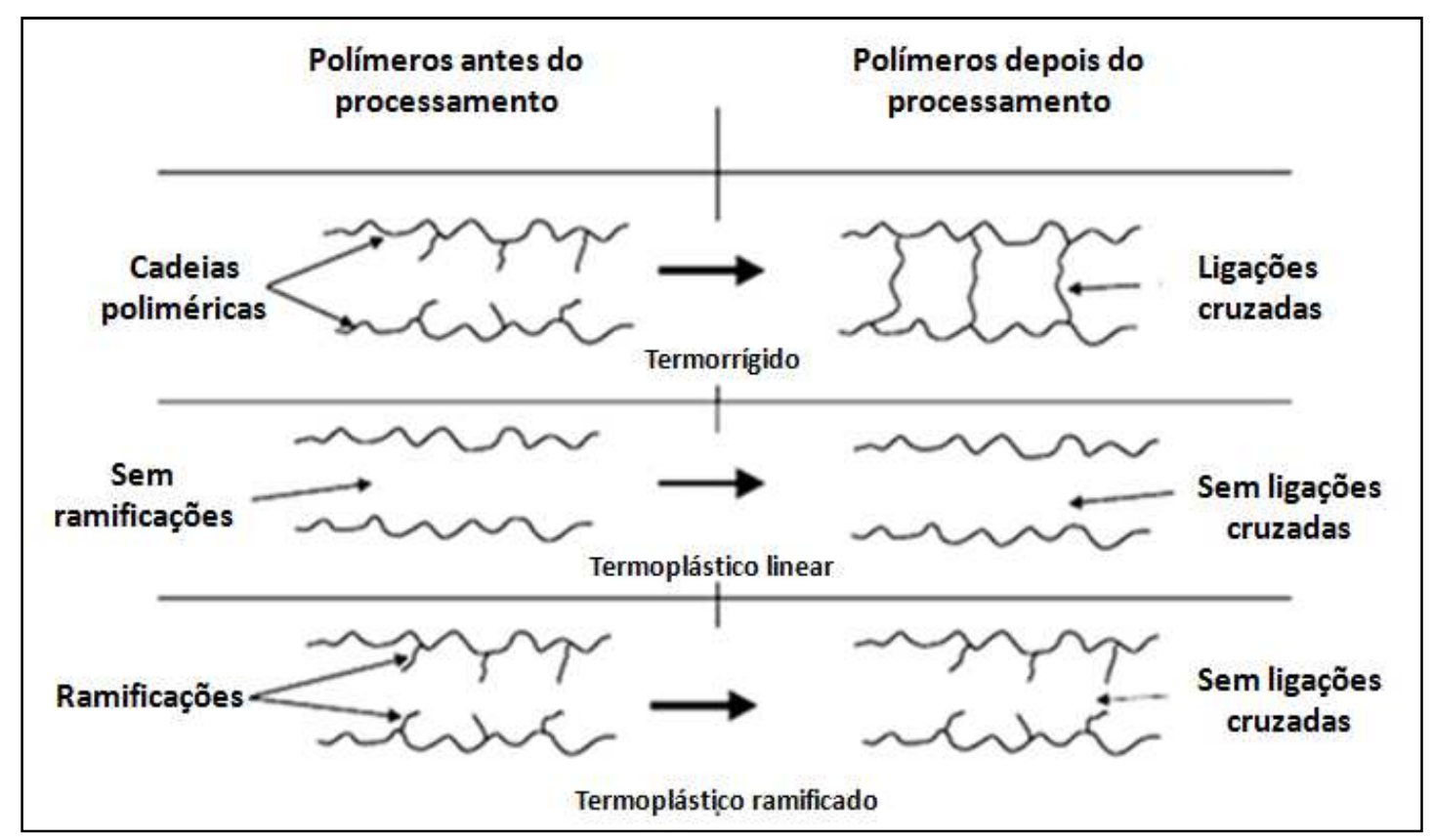

Figura 2.14 - Comparação simplificada da estrutura molecular das resinas termorrígidas e dos polímeros termoplásticos, estes últimos exibindo, respectivamente, cadeias lineares e ramificadas (Adaptado de CAMPBELL, 2006).

O processo de soldagem de termoplásticos e, conseqüentemente, de compósitos de matriz termoplástica apresenta três fases distintas (CAMPBELL, 2006), que são o aquecimento, a consolidação e o resfriamento, todas elas controladas por ao menos duas das seguintes três variáveis de processo, quais sejam, tempo, temperatura e pressão (Figura 2.15).

Aquecimento - Esta fase consiste no aquecimento das partes a serem unidas, sendo o tempo uma função do método de aquecimento utilizado. Não se aplica pressão nesta fase. Para termoplásticos amorfos a temperatura deve ser elevada significativamente acima da temperatura de transição vítrea $\left(T_{g}\right)$, enquanto que, para os termoplásticos semicristalinos, a temperatura deve ser algo superior à temperatura de fusão $\left(T_{m}\right)$.

Consolidação - A consolidação das partes termoplásticas ocorre pelo processo de interdifusão macromolecular (Figura 2.16). Através do íntimo contato entre as partes aquecidas, forçado pela aplicação de relativamente altas pressões sobre as partes a serem unidas, as cadeias poliméricas se difundem através da interface comum e se entrelaçam, proporcionando a integração entre as duas partes inicialmente separadas, numa massa considerável de material localizado nas 
proximidades das respectivas superfícies em contato inicial. Em geral, quando se aplicam altas pressões e elevadas temperaturas de processo, a consolidação ocorre em um tempo mais curto, assim como o incremento do tempo de contato geralmente favorece a soldagem, não obstante a degradação térmica das macromoléculas deva ser uma preocupação permanente durante o processamento termomecânico do material.

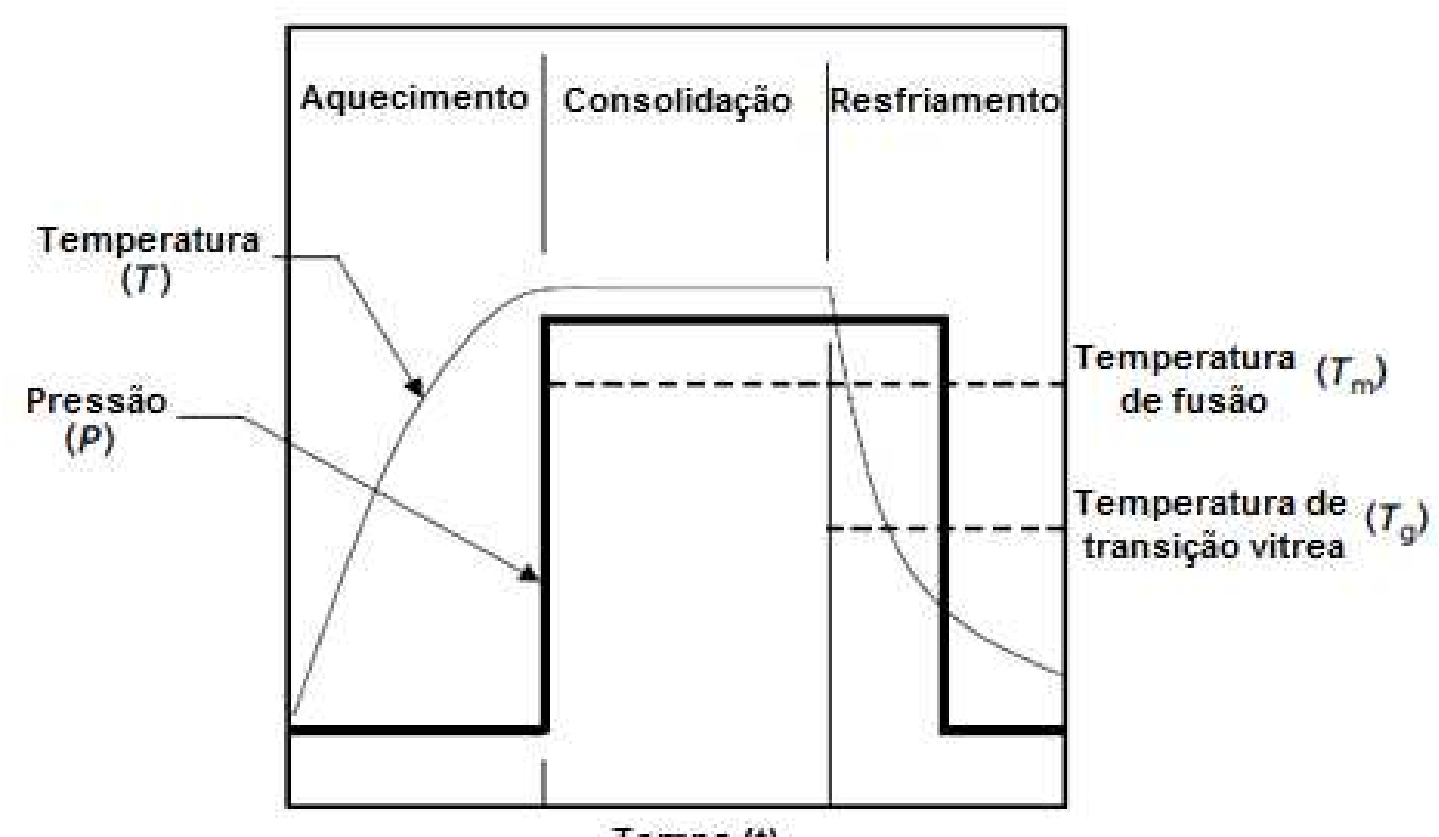

Figura 2.15 - Ciclo típico do processo de união por soldagem de termoplásticos (Adaptado de AGEORGES et al., 1998).

Resfriamento - Durante o resfriamento, a pressão deve ser mantida até que a temperatura se estabeleça bem abaixo da temperatura de transição vítrea do polímero. Isso restringe a nucleação de vazios, suprime a recuperação elástica da macromolécula e ajuda a manter as tolerâncias, dimensões e o formato desejados do produto final. Para polímeros semicristalinos, a taxa de resfriamento não pode ser muito rápida, visto ser necessário determinado tempo para que se garanta o reordenamento de sua estrutura intrinsecamente semicristalina, assim como a devida relaxação molecular, evitando-se desta forma as indesejáveis tensões residuais originadas por transformações de estado físico da matéria e/ou advindas de efeitos térmicos e/ou decorrentes de fenômenos de natureza visco-elástica. 


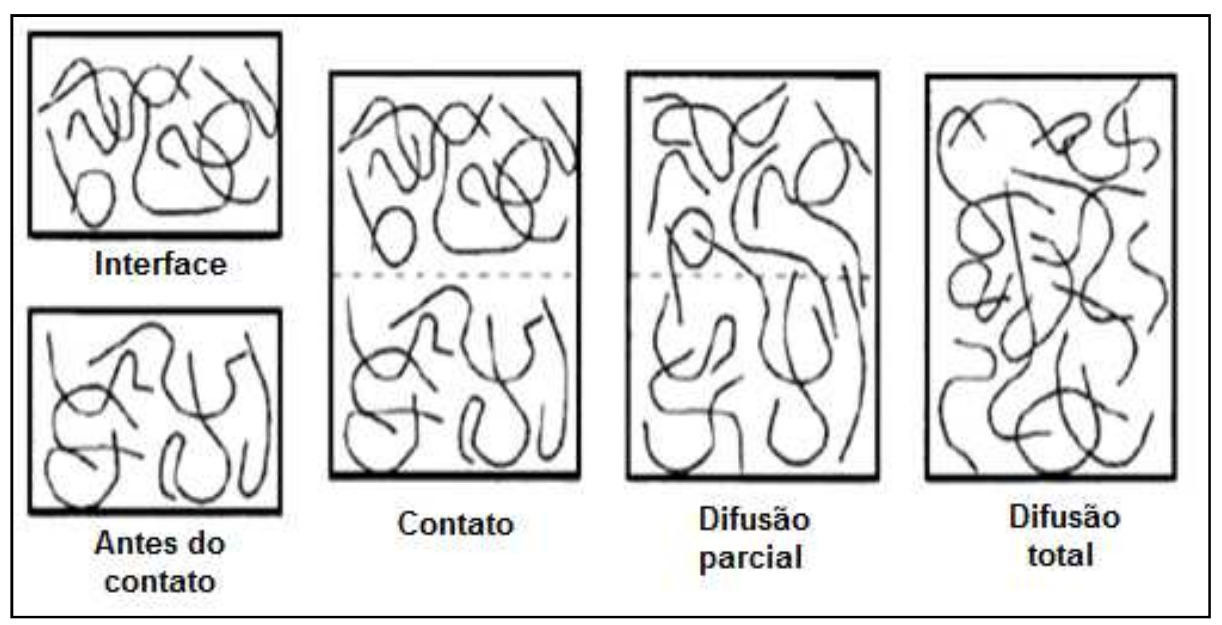

Figura 2.16 - Interdifusão macromolecular na interface de solda de peças termoplásticas (Adaptado de AGEORGES et al., 1998).

Para as resinas termorrígidas, o processo descrito acima, não se aplica, pois uma vez curadas, mediante aplicação de calor, esta forma ligações cruzadas (Figura 2.14 que a impedem de uma vez reaquecidas de fundir-se novamente, ou seja, ao invés de sofrer fusão, a resina curada submetida a sua temperatura de processamento degrada-se (MATTHEWS e RAWLINGS, 2003).

\subsubsection{Principais metodologias de soldagem}

A técnica de fusão (ou de amolecimento) de um polímero termoplástico é geralmente classificada de acordo com a tecnologia empregada para aquecer as partes que serão unidas. Em geral, essas tecnologias são divididas em três grandes categorias, que são as soldagens por fricção, eletromagnética e térmica.

$\mathrm{Na}$ soldagem por fricção, o calor é gerado por atrito na interface das áreas das partes a serem unidas, até a matriz polimérica atingir a temperatura acima da temperatura de fusão, ou de amolecimento. Então, as partes são mantidas em forte contato pressionando-se uma contra a outra.

A soldagem eletromagnética, ou por resistência elétrica envolve o uso de um material condutor na interface de união entre as partes, tal como, por exemplo, malhas de aço, de carbono, ou partículas condutoras. Então, um campo 
eletromagnético, ou então uma diferença de potencial elétrico é aplicada ao elemento gerador de calor (“susceptor") em que ou se desenvolverão as chamadas correntes elétricas parasitas, ou, então, no qual será gerada uma corrente elétrica alternada, sendo que em ambos os casos calor será produzido por efeito resistivo (efeito Joule) aquecendo, por conseqüência, o polímero ao redor.

A última categoria é a soldagem térmica (ou de duplo-estágio), onde o calor é aplicado diretamente na superfície a ser soldada, seguido da aplicação de pressão ao sistema para manter as partes unidas (DE BAERE et al., 2012). A Figura 2.17 mostra a classificação dos processos de soldagem de acordo com a tecnologia empregada para a geração de calor.

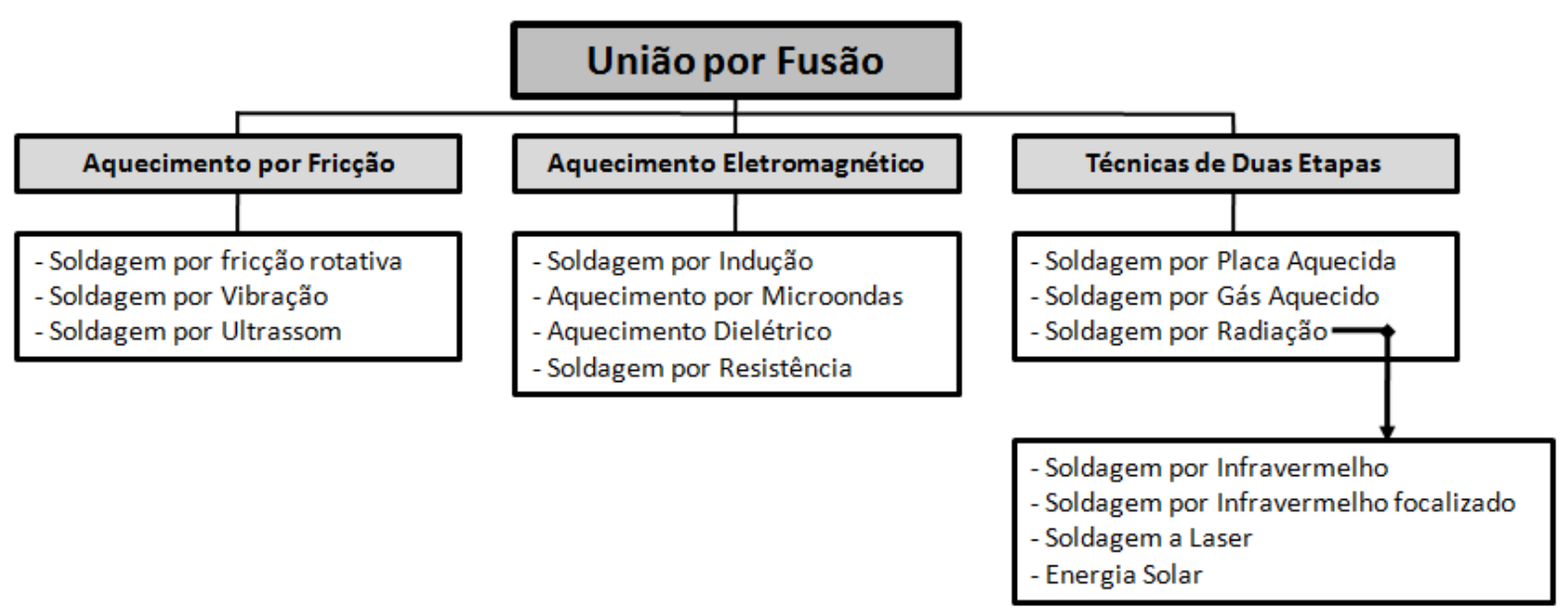

Figura 2.17 - Tecnologias e processos de soldagem aplicados aos laminados compósitos termoplásticos (Adaptado de AGEORGES et al., 2001).

A Tabela 2.1 lista os principais fatores que caracterizam os processos de união de partes termoplásticas mais empregados atualmente, bem como estabelece valores que quantificam o mérito destes fatores numa escala de 0 (menos adequado) a 10 (mais adequado), possibilitando o estabelecimento de ordenamento classificatório entre as várias técnicas de soldagem disponíveis.

Dentre as técnicas de soldagem de polímeros termoplásticos e seus respectivos compósitos listadas na Tabela 2.1, AGEORGES et al. (2001) consideram que as três mais promissoras são a soldagem por ultrassom, por indução eletromagnética e por resistência elétrica. Contudo, para materiais poliméricos reforçados com fibras contínuas, a principal barreira para o uso de soldagem ultrassônica é a dificuldade 
de introduzir os direcionadores de energia nos componentes que serão unidos, e o conseqüente risco de ruptura da fibra na interface que fica exposta a uma grande deformação da área de soldagem, a qual (alta deformação) é necessária para se obter uma união satisfatória por fusão (SCHWARTZ, 1994).

Tabela 2.1 Comparação entre várias técnicas de união de polímeros e compósitos termoplásticos (Adaptado de SILVERMAN \& GRIESE, 1989).

\begin{tabular}{|c|c|c|c|c|c|c|c|c|c|c|c|c|c|}
\hline & Performace & Reprodutibilidade & Durabilidade & Custo & $\begin{array}{l}\text { Tempo de } \\
\text { processamento }\end{array}$ & $\begin{array}{c}\text { Preparação } \\
\text { mínima } \\
\text { da superfície }\end{array}$ & Flexibilidade & $\begin{array}{l}\text { União de } \\
\text { grandes } \\
\text { partes }\end{array}$ & $\begin{array}{l}\text { Inspeção } \\
\text { em } \\
\text { tempo } \\
\text { real } \\
\end{array}$ & $\begin{array}{c}\text { Automação } \\
\text { da } \\
\text { Produção }\end{array}$ & $\begin{array}{c}\text { Portabilidade } \\
\text { Aplicação em } \\
\text { reparos }\end{array}$ & $\begin{array}{l}\text { Reprocessamento } \\
\text { Reciclagem }\end{array}$ & $\begin{array}{l}\text { Impacto ao } \\
\text { Meio } \\
\text { Ambiente }\end{array}$ \\
\hline União Mecânica & 4 & 10 & 5 & $2-7$ & 2 & 2 & 10 & 10 & 5 & 10 & 10 & 10 & 10 \\
\hline $\begin{array}{l}\text { União por } \\
\text { Colagem }\end{array}$ & 10 & 5 & 5 & $3-7$ & 0 & 2 & 10 & 10 & 10 & 10 & 10 & 0 & 2 \\
\hline $\begin{array}{l}\text { Soldagem por } \\
\text { Resistência }\end{array}$ & 10 & 8 & 8 & $7-6$ & 8 & 10 & 5 & 8 & 10 & 10 & 8 & 8 & 8 \\
\hline $\begin{array}{l}\text { Soldagem por } \\
\text { Ultrassom }\end{array}$ & 10 & 9 & 9 & $8-6$ & 10 & 10 & 5 & 5 & 10 & 10 & 7 & 5 & 8 \\
\hline $\begin{array}{l}\text { Soldagem por } \\
\text { Indução }\end{array}$ & 10 & 9 & 8 & $7-6$ & 8 & 10 & 7 & 8 & 10 & 10 & 7 & 8 & 8 \\
\hline $\begin{array}{l}\text { Técnicas de } \\
\text { Duas Etapas }\end{array}$ & 10 & 9 & 9 & $7-5$ & 7 & 10 & 7 & 2 & 5 & 10 & 8 & 2 & 8 \\
\hline
\end{tabular}

Nos tópicos seguintes deste texto, os métodos de soldagem por indução eletromagnética e por resistência elétrica são descritos em maiores detalhes, tendo em vista que, atualmente, são aqueles efetivamente empregados pela indústria de construção aeronáutica. De particular interesse e requintes de detalhes é o caso da técnica de resistência elétrica, visto que este método foi utilizado na confecção de uma das duas classes de juntas estudadas no presente projeto de pesquisa.

\subsubsection{Soldagem por resistência elétrica}

O método da soldagem por resistência elétrica consiste em se gerar calor através do implante de um material condutivo (elemento gerador de calor) entre as duas partes que serão soldadas sob a aplicação de pressão. Quando este material é submetido a uma corrente elétrica, calor é gerado devido ao efeito Joule. A rigor, este método de soldagem é análogo ao de indução eletromagnética, exceto que, 
neste último, o elemento gerador de calor permanece fisicamente isolado (sem contato físico) da fonte de corrente elétrica durante o procedimento de soldagem.

Conforme a temperatura aumenta, a matriz termoplástica ao redor do elemento gerador de calor aquece até o polímero atingir uma temperatura superior à temperatura de fusão (para os polímeros semicristalinos), ou uma temperatura adequada de amolecimento (polímeros amorfos). Quando todo o material ao redor do implante estiver fundido ou amolecido, a corrente elétrica é desligada e a área de soldagem começa a resfriar, ainda com forte pressão aplicada entre as partes, uma contra a outra, até a solidificação completa da área de solda, obtendo-se assim o produto final consolidado.

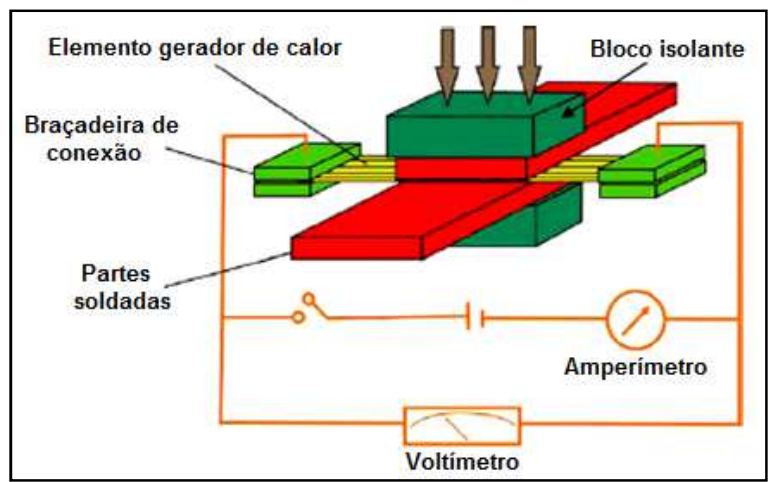

Figura 2.18 - Esquemático de um dispositivo para soldagem de juntas sobrepostas termoplásticas por resistência elétrica (Adaptado de STAVROV \& BERSEE, 2005).

A Figura 2.18 mostra um esquema de dispositivo usado para a soldagem por resistência elétrica. Os componentes que formam este dispositivo são: elemento gerador de calor, uma fonte de energia elétrica (com voltímetro e amperímetro), conectores elétricos e fios, blocos de isolamento e os aderentes (laminados compósitos fibrosos sólidos) que serão soldados. Além disso, termopares podem ser usados para o controle da temperatura em que se desenvolve o processo.

Assim como na soldagem por indução, o elemento gerador de calor fica permanentemente instalado na interface da junta, portanto, a compatibilidade da matriz polimérica com o material que constitui o elemento gerador de calor é um fator critico do processo, já que a presença deste elemento afetará negativamente, em maior ou menor extensão, o desempenho mecânico da junta em serviço. 


\subsubsection{Energia aplicada ao sistema}

São importantes parâmetros para o processo de soldagem por resistência elétrica a potência aplicada $(P)$ e a energia gerada $(E)$, também por unidade de área na interface de soldagem. Assim, tem-se que:

$$
\begin{aligned}
& P=I^{2} \cdot R / L . W \\
& E=P . t
\end{aligned}
$$

Onde I é a corrente elétrica que atravessa o implante condutor, $\mathrm{R}$ é a sua resistência elétrica (Ohms), t é o tempo que o sistema permanece ligado, ou seja, com a presença da corrente elétrica passando pelo elemento gerador de calor, e $\mathrm{L}$ e W são, respectivamente, o comprimento e a largura da área de soldagem.

Aplicando o processo de soldagem por resistência elétrica em juntas sobrepostas simples de laminados compósitos de matriz termoplástica PEI - PoliÉter-Imida reforçada com fibras continuas de carbono, HOU et al. (1999) obtiveram uma janela de processamento relativamente ao nível de potência aplicada ao sistema. Seu experimento determinou um valor mínimo de $80 \mathrm{KW} / \mathrm{m}^{2}$ e um máximo de $160 \mathrm{KW} / \mathrm{m}^{2}$ para uma soldagem considerada bem-sucedida. HOU et al. (1999) observaram que, para níveis de potência inferiores a $80 \mathrm{~kW} / \mathrm{m}^{2}$, o polímero precisava de um tempo muito maior para fundir (acima de 5 minutos). Para níveis de potência superiores a $160 \mathrm{KW} / \mathrm{m}^{2}$ a taxa de aquecimento foi alta, obtendo-se assim um tempo de soldagem curto. Contudo, foi verificado que as temperaturas atingidas eram excessivas, causando a degradação térmica do polímero e a oxidação da fibra de reforço, levando conseqüentemente a reduções substanciais da eficiência mecânica da junta.

Na literatura referente à forma como a potência é aplicada ao elemento gerador de calor, três métodos são populares. No primeiro método, o nível de potência aplicada ao sistema é realizado com voltagem constante. Entretanto, embora a voltagem seja constante o nível de potência não é, pois a resistência do implante 
varia com o aumento da temperatura, variando assim o nível de potência aplicada ao sistema. Para implantes de malha de aço inoxidável a resistência aumenta com a temperatura resultando em um nível de potência menor ao longo do tempo de aquecimento do sistema (DUBÉ, 2007).

ARIAS \& ZIEGMANN (1996) propuseram um segundo método denominado de soldagem por resistência com impulso elétrico ("Impulse Resistence Welding" - IRW) onde a potência é aplicada de forma intermitente e intensa (até $600 \mathrm{KW} / \mathrm{m}^{2}$ ) com pausas de 1 a 3 segundos, com menos energia para provocar a fusão em função da menor perda de calor no processo, obtendo-se uma distribuição mais uniforme de calor na área de soldagem.

YOUSEFPOUR et al. (2005) sugeriram um terceiro método caracterizado pela aplicação em rampa (crescente) da voltagem, obtêm-se assim uma distribuição mais uniforme da temperatura e a perda de calor é reduzida (em relação ao primeiro método), o que garante taxas mais constantes de dissipação de calor na interface da solda.

\subsubsection{Elemento gerador de calor}

Outro item que compõe o sistema de soldagem por resistência elétrica e, provavelmente, o mais importante dentre todos, é o elemento gerador de calor (implante), que permanece na interface das partes unidas mesmo após a soldagem.

O elemento gerador de calor é importante na soldagem por resistência de termoplásticos reforçados por fibras, já que afeta diretamente tanto a geração de calor na interface, assim como as propriedades mecânicas da junta final (CHAZERAIN, 2009). O elemento gerador de calor pode ser feito de qualquer material que conduza energia elétrica, tal como malhas de aço, fibras uni- ou bidirecionais de carbono, esteja estas na forma pura ou semi-impregnadas com polímero termoplástico (SHI et al., 2013).

Comparando o uso de tecidos bi-direcionais com o de fibras unidirecionais de carbono, como elementos geradores de calor, os tecidos apresentam melhor 
desempenho por prover melhor distribuição de calor na área de soldagem, enquanto que para as fitas a distribuição de calor não é uniforme devido à baixa condutividade térmica no sentido transversal das fibras que as constituem, aumentando assim o gradiente de temperaturas na área de soldagem (DUBÉ, 2007).

Outro aspecto importante quanto ao uso de fibras de carbono como elemento gerador de calor surge quando elas são usadas no processo de soldagem de termoplásticos reforçados por fibra de carbono. Como ambos o implante e o reforço são condutores elétricos, o contato entre eles durante o processo de soldagem causa o chamado "vazamento de corrente", gerando perda de calor na área de solda, diminuindo assim a eficiência, a qualidade do processo e do produto final.

Devido aos problemas reportados pelo uso de fibras de carbono como elemento gerador de calor surgiu o interesse de estudar a aplicação de outros tipos de materiais, dentre os quais vem se destacando as malhas de aço inoxidável. As malhas de aço como elemento gerador de calor melhoraram a homogeneidade da temperatura na área da solda, além de serem mais resistentes à pressão no contato com os conectores elétricos, obtendo-se melhor desempenho mecânico, melhor controle, repetibilidade e reprodutibilidade do processo (STAVROV \& BERSEE, 2005).

As malhas de aço inoxidável estão disponíveis em várias gradações, com diferentes diâmetros de fio e espaçamento entre os mesmos. Para melhorar o desempenho mecânico do produto final (junta compósita termoplástica fibrosa soldada), os efeitos dos dois parâmetros de malha supramencionados na qualidade da junta precisam ser avaliados, pois esses parâmetros têm impacto direto na resistência elétrica da malha e, conseqüentemente, na geração de calor na área de solda. Eles também afetam a difusão do polímero fundido, ou amolecido, a espessura da solda, a tensão residual e a concentração de tensão ao redor dos fios.

DUBÉ et al. (2011) investigaram a aplicação de diferentes configurações de malhas de aço variando o diâmetro e o espaçamento entre os fios metálicos para juntas sobrepostas simples ensaiadas em tração monotônica quase-estática dos seguintes laminados termoplásticos fibrosos: PEEK - Poli-Éter-Éter-Cetona e PEI Poli-Éter-Imida reforçados com fibras contínuas de carbono (FC), e PEI reforçado com fibras contínuas de vidro (FV). A malha de aço feita com fios de diâmetro 0,04 $\mathrm{mm}$ e espaçamento entre fios de $0,09 \mathrm{~mm}$ apresentou o melhor desempenho 
mecânico para todos os materiais testados na configuração de juntas sobrepostas simples de cisalhamento, com resistências de 52, 47 e $33 \mathrm{MPa}$ obtidos para os pares FC/PEEK, FC/PEI e FV/PEI, respectivamente.

Juntas com malhas metálicas com maiores diâmetros de fio exibiram baixo desempenho porque os fios, e as respectivas tramas, agiram como inclusões (defeitos) na área de solda. Diâmetros muito pequenos de fio, por outro lado, prejudicaram o desempenho mecânico final da junta, pois a respectiva trama é muito fechada, dificultando a vazão, ou a passagem através da mesma do polímero fundido, ou amolecido, e, conseqüentemente, favorecendo a geração de regiões pobres em resina (vazios, bolhas), que constituem graves defeitos de manufatura.

Em outro trabalho, DUBÉ et al. (2008) avaliaram o uso de malhas de aço revestidas com um material isolante de natureza cerâmica $\left(\mathrm{TiO}_{2}\right)$ de modo a prevenir, ou minimizar o "vazamento de corrente elétrica" durante o processo de soldagem. Os pesquisadores obtiveram resultados significativamente superiores aos verificados com malhas de aço sem este revestimento, uma vez que o revestimento cerâmico que cobria a malha impediu o vazamento de corrente elétrica para 0 aderente de fibra de carbono.

\subsubsection{Blocos isolantes}

Os blocos isolantes atuam no sentido de minimizarem a perda de calor do sistema para o ambiente. Portanto, são candidatos a esta função os materiais que apresentam boas propriedades isolantes, tais como a madeira, a borracha e os materiais cerâmicos, dadas suas intrinsecamente baixas condutividades térmicas.

Em seu trabalho de modelagem numérica comparando o uso de dois diferentes tipos de blocos isolantes, respectivamente de aço e cerâmica, TALBOT (2005) observou que as propriedades térmicas do bloco isolante têm grande influência no tempo total do processo de soldagem e no gradiente de temperatura ao longo da espessura das partes soldadas, sendo que, neste sentido, os blocos cerâmicos mostram ser a melhor opção. 


\subsubsection{Aderentes}

Praticamente todos os termoplásticos podem ser soldados usando-se a técnica de soldagem por resistência elétrica, e esta pode ser também aplicada para soldar materiais dissimilares, incluindo muitas combinações entre termoplásticos, termoplásticos reforçados por fibras, resinas termorrígidas e seus compósitos, e metais e suas ligas, quase que invariavelmente empregando-se filmes de termoplástico como elemento adesivo (MICHAEL, 1997).

Contudo, tendo como ênfase os laminados estruturais termoplásticos sólidos reforçados por fibras contínuas, inicialmente a escolha de matrizes poliméricas recaia tipicamente em polímeros amorfos, tais como o Poli-Éter-Sulfona (PES) e o Poli-Éter-Imida (PEI); porém estes foram progressivamente substituídos por polímeros semicristalinos, tais como o Poli-Sulfeto de Fenileno (PPS), Poli-Éter-ÉterCetona (PEEK), Poli-Éter-Cetona-Cetona (PEKK), dentre outros, devido a excelente resistência química e as atraentes propriedades mecânicas dos últimos.

Um exemplo de aplicação na indústria aeronáutica do polímero PPS reforçado com fibra de vidro é o "J-nose leading edge" dos Airbus A340-500/600 e A380, onde a maioria de suas partes é unida por soldagem por resistência elétrica (Figura 2.19).

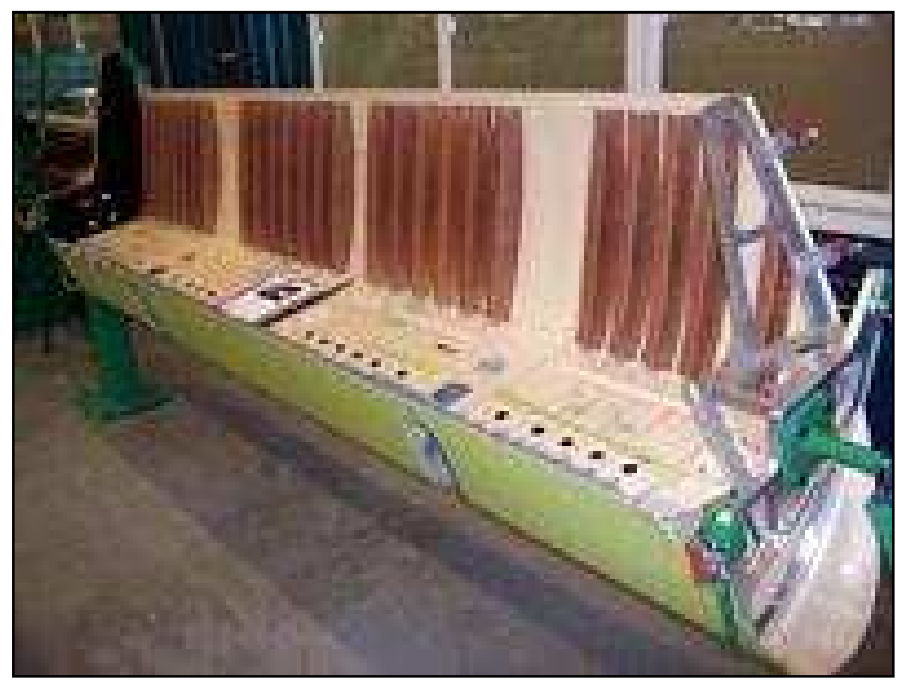

Figura 2.19 - J-nose leading edge do Airbus A340-500/600 e do A380 (http://www.compositesworld.com/articles/thermoplastic-composites-gain-leading-edge-onthe-a380 acesso em 2012). 
Trabalhos mais recentes com polímeros ainda mais avançados que o PPS, incluindo o Poli-Éter-Éter-Cetona (PEEK) e o poli-éter-cetona-cetona (PEKK) ainda não expandiram sua aplicação devido ao seu alto custo, assim como devido às dificuldades de seu processamento que demandam altas temperaturas, variando de $300^{\circ} \mathrm{C}$ a $400^{\circ} \mathrm{C}$, e enormes pressões decorrentes das extremamente elevadas viscosidades dos respectivos materiais fundidos (compositesworld, acesso em 2012).

\subsubsection{Efeito de borda}

A distribuição não uniforme de temperatura na área de soldagem é um dos fatores que devem ser levados em conta durante o processo de soldagem por resistência elétrica, pois pode ocorrer não uniformidade de transferência de calor na área de solda devido à danificação parcial do elemento gerador de calor, à ineficiência da conexão elétrica, ou devido ao chamado "vazamento de corrente" (DUBÉ, 2007, 2008).

Outro fenômeno associado a não uniformidade de temperatura no processo de soldagem por resistência elétrica é o chamado "efeito de borda" que é causado principalmente pela pobre transferência de calor por convecção natural entre 0 elemento gerador de calor e o ar, em oposição à elevada transferência de calor por condução entre o elemento gerador de calor e o aderente. Então, a parte do implante exposta ao ar aquece mais rapidamente que a parte que fica entre os aderentes, fazendo com que as bordas fiquem mais quentes. Com isso, a fusão se inicia nas bordas da peça e caminha em direção ao seu centro até a fusão completa do material do aderente em contato com o implante (Figura 2.20), (HOU et al., 1999). 


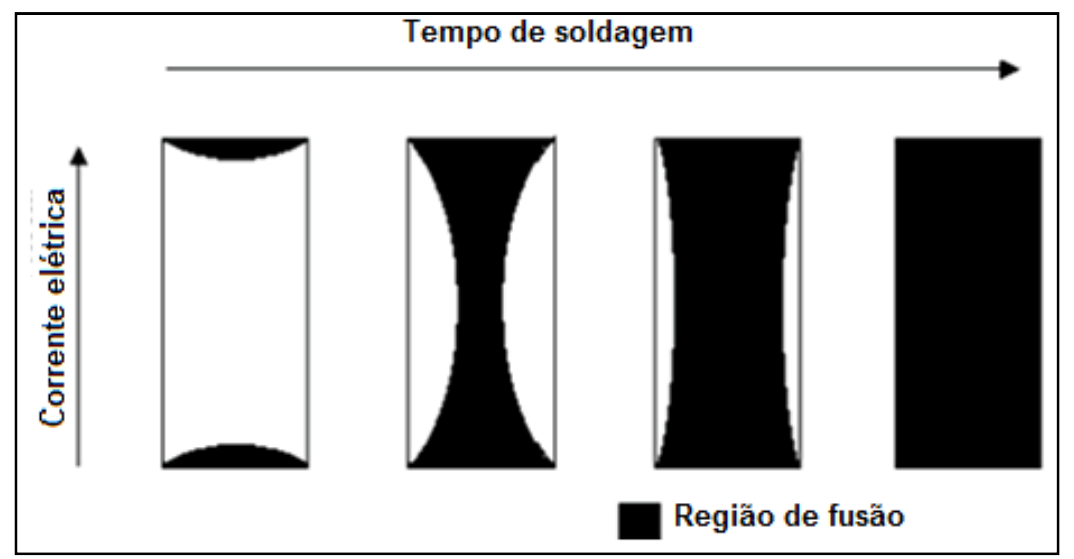

Figura 2.20 - Propagação das frentes de fusão na interface entre os aderentes (Adaptado de HOU et al.,1999).

Durante o processo de soldagem por resistência de juntas sobrepostas simples feitas em aderentes confeccionados com resina termoplástica PEI reforçada com fibra de carbono, HOU et al. (1999) observaram o efeito na borda através do uso de termopares colocados na interface de união. Dois deles foram instalados próximos à borda da peça e o terceiro foi instalado no centro da mesma, constatando-se que a temperatura nas bordas é sempre maior que no centro, tal como ilustrado na Figura 2.21 .

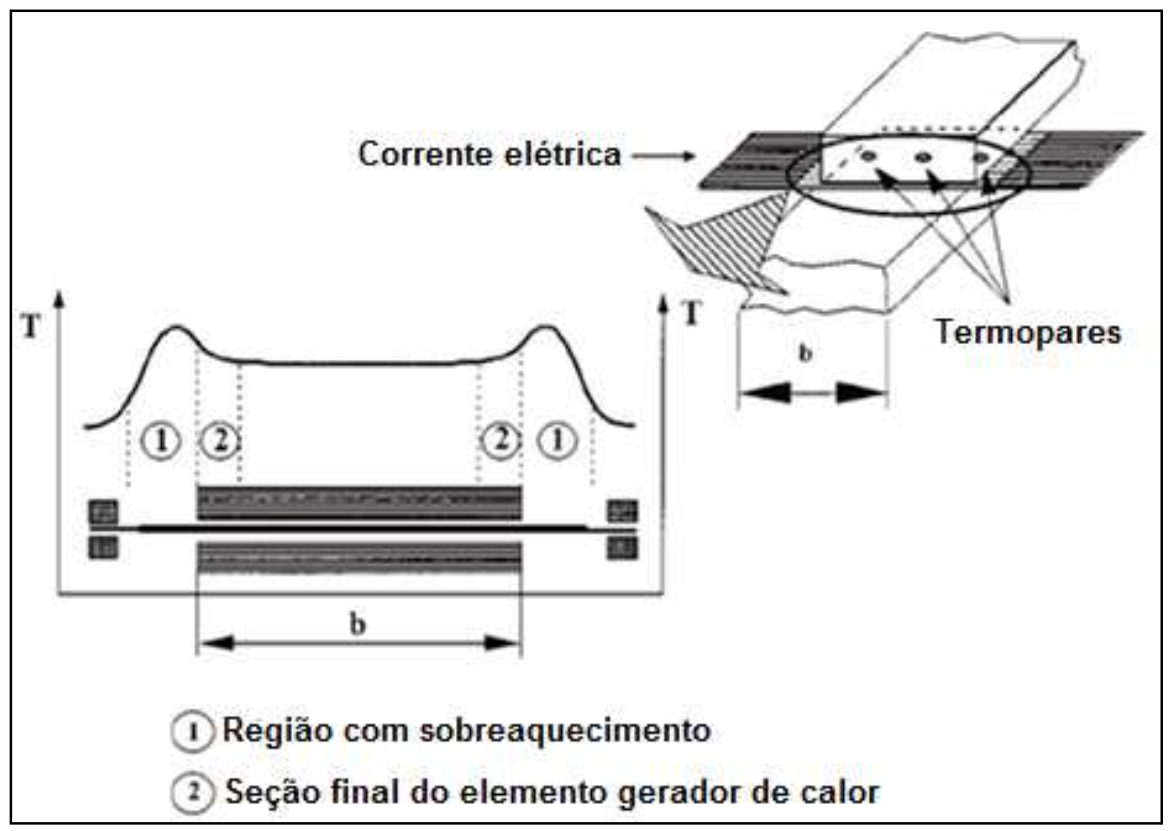

Figura 2.21 - Distribuição da temperatura ao longo da linha de união entre aderentes compósitos fibrosos de matriz termoplástica (Adaptado de HOU et al.,1999). 
Contudo, é possível diminuir a influência do efeito de borda variando-se a distância entre o conector usado para aplicar a corrente elétrica ao elemento gerador de calor, e os laminados a serem soldados.

Aplicando o método de soldagem por resistência elétrica em juntas sobrepostas simples de laminados compósitos de polímero termoplástico PEI reforçado com fibras contínuas de vidro, STAVROV \& BERSEE (2003) estudaram o efeito da variação da distância entre o conector e a região a junta.

Assim como HOU et al. (1999), eles monitoraram a temperatura com o auxílio de termopares instalados ao longo de uma linha na área de solda, sendo dois termopares localizados nas bordas da peça e um no seu centro, tal como ilustrado na Figura 2.22.

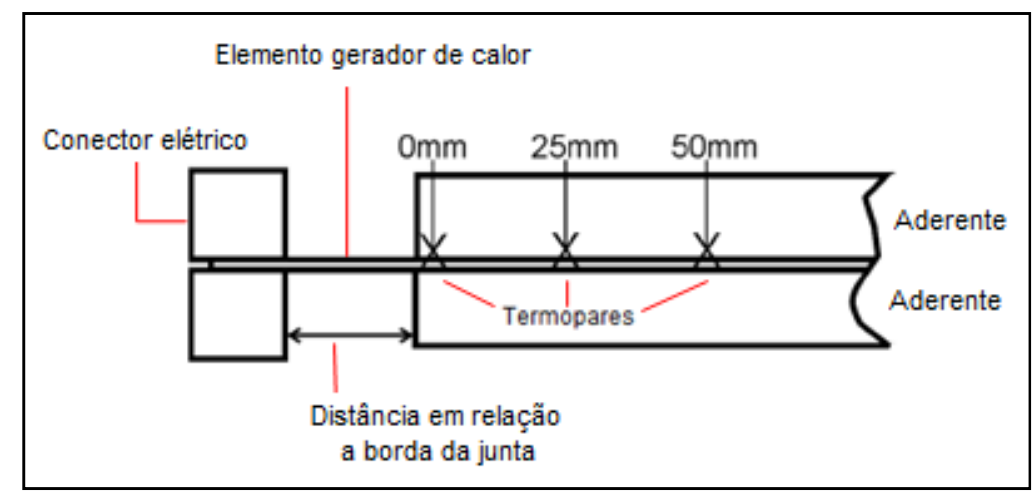

Figura 2.22 - Efeito da distância do conector à junta na distribuição da temperatura (Adaptado de STAVROV \& BERSEE, 2003).

As medidas de temperatura foram realizadas variando-se a distância entre os conectores e a junta em $10 \mathrm{~mm}, 5 \mathrm{~mm}$ e $0 \mathrm{~mm}$ (conectores em contato com a mesma). Para a distância de $10 \mathrm{~mm}$ observou-se uma diferença de temperatura de $100^{\circ} \mathrm{C}$ entre as bordas e o centro da área de solda. Nestas circunstâncias pode ocorrer degradação térmica do polímero nas bordas devido à alta temperatura local. Para a distância de $5 \mathrm{~mm}$ esta diferença diminuiu para $70^{\circ} \mathrm{C}$, e para a distância de 0 $\mathrm{mm}$ a diferença de temperatura foi de apenas $20^{\circ} \mathrm{C}$, devido ao resfriamento da borda através do contado com os conectores e, conseqüentemente, havendo a transferência de calor por condução. Assim, o controle da distância dos conectores parece um método efetivo para melhorar a distribuição de temperatura na área da solda. No entanto, a distância ótima vai variar de acordo com o material dos 
conectores, do tipo de elemento gerador de calor, aderentes, blocos de isolamentos e o nível de energia aplicada ao sistema. Mais atualmente, REQUENA et al. (2013) revisaram este importante tópico, gerando dados de grande interesse ao leitor mais interessado neste assunto.

\subsubsection{Geometria de junta para corpos de provas}

$\mathrm{Na}$ literatura, as investigações experimentais sobre soldagem por resistência elétrica são, em geral, realizadas através do uso de corpos de prova soldados na forma de juntas sobrepostas simples. Além de ser o tipo mais simples de geometria, os espécimes podem ser caracterizadas através de inspeções por ensaios nãodestrutivos (inspeção termográfica, ultrassônica, etc.) e avaliações destrutivas (microscopia óptica e eletrônica de varredura). Todas estas vantagens favorecem grandemente a utilização desse tipo de espécime de ensaio para a avaliação e a otimização dos parâmetros do processo de soldagem por resistência.

Contudo, uma vez que o processo de soldagem por resistência elétrica tem aplicações na indústria aeronáutica, o espécime ensaiado deve representar da melhor maneira as condições reais que a estrutura de uma aeronave experimenta durante sua operação em serviço. Um exemplo é a fuselagem, que é uma estrutura sujeita a carregamentos fora do plano causados pela pressão interna na cabine. Uma vez que esta estrutura recebe carregamentos fora do plano ela é feita com reforços internos como nervuras (DUBÉ, 2007).

MINGUET \& O'BRIEN (1996) desenvolveram um espécime com configuração geométrica denominada revestimento/nervura que consiste em um flange de compósito representando o reforço (ou nervura) colado em outro laminado que representa o revestimento (Figura 2.23). 


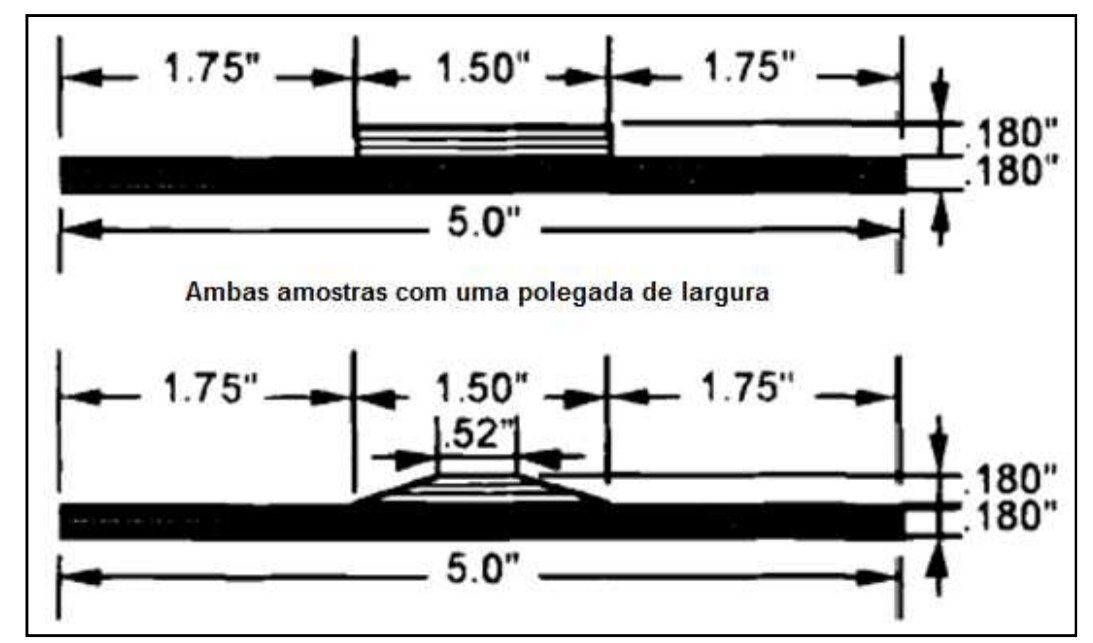

Figura 2.23 - Configuração geométrica do espécime do tipo revestimento/nervura (Adaptado de MINGUET \& O'BRIEN, 1996).

As bordas do flange que representa o reforço são retrabalhadas para reduzir a concentração de tensão. O espécime com o flange retrabalhado com ângulo de $20^{\circ}$ reduziu a tensão na borda, o que ocasionou um desempenho mecânico 30\% superior em relação ao flange sem o retrabalho. Portanto, a concentração de tensão na borda aparece como problema e precisa ser investigado.

MINGUET \& O'BRIEN (1996) compararam corpos de prova removidos de painéis reforçados confeccionados em escala real (empregando-se laminados de matriz termorrígida e colagem) com corpos de prova com a geometria de revestimento/nervura carregada em flexão sob três e quatro pontos. Os experimentos revelaram que os mecanismos de falha para as duas geometrias ensaiadas foram os mesmos. Esses resultados mostraram que os modos de falha da estrutura em escala real podem ser estudados através de espécimes com geometria revestimento/nervura, os quais são bem mais simples e demandam muito menor custo de fabricação.

DUBÉ et al. $(2011,2009,2008)$ em seus diversos trabalhos de caracterização mecânica de produtos de soldagem por resistência elétrica de laminados compósitos termoplásticos fibrosos, em especial da classe APC-2/AS4, qual seja, PEEK + fibra de carbono fornecido pela CYTEC ${ }^{\circledR}$ Engineered Materials Inc., avaliaram espécimes com arranjos de fibras unidirecional e quase-isotrópico reproduzindo exatamente as geometrias e dimensões estabelecidas por MINGUET \& O'BRIEN (1996). Em geral, os corpos de prova laminados com ambas as configurações de fibras foram 
submetidos a ensaios de carregamento cíclico em flexão sob três pontos. Alguns resultados de fadiga mostraram vida infinita para níveis de tensão máxima da ordem de 35 a $40 \%$ da carga estática de ruptura para, respectivamente, os arranjos unidirecional e quase-isotrópico de fibras de reforço. Quanto à caracterização das falhas, os espécimes com fibras unidirecionais tipicamente falharam na interface da solda, enquanto que os corpos de prova com arquitetura quase-isotrópica de fibras contínuas exibiram delaminações no laminado do flange, do revestimento e na interface da solda.

\subsubsection{Modos de falha}

Neste trabalho, considerando-se os aspectos macroscópicos da falha, ou seja, por intermédio de uma análise puramente visual das superfícies de fraturas da junta termoplástica soldada, definiu-se os modos de falha simplesmente como interfacial e intralaminar. Considerada a Figura 2.24a, onde a junta é formada por dois aderentes unidos ao elemento de junção (este sendo formado pela malha metálica + filme de PPS adicionados em cada face da malha, conforme definição a ser apresentada no capítulo 3.1), o modo de falha interfacial ocorre na interface entre o elemento de união e o aderente (Figura 2.24b) e pode ser causado pela interação imperfeita entre os mesmos durante o processo de soldagem, ocasionando, em geral, baixos valores de resistência ao cisalhamento por parte da junta. De modo mais objetivo, esta falha poderia ser vista como o descolamento dos filmes puros de PPS pertencentes ao conjunto ora denominado elemento de união (inserto permanente de malha metálica + filmes de PPS em suas duas faces) da superfície do aderente (laminado compósito) a qual é constituída de PPS reforçado com fibras de vidro na forma de tecido bidirecional. Quanto ao modo de falha intralaminar, neste trabalho é assumido que ele ocorre no interior do elemento de união (malha metálica + filmes de PPS adicionados um em cada face da mesma), ocasionado assim danos internos ao elemento gerador de calor (Figura 2.24c). Este processo pode ser desencadeado por imperfeições na consolidação entre as fases metálica e polimérica no elemento gerador de calor durante a soldagem. O resultado final é a exposição total da malha 
na superfície de fratura (o que, rigorosamente falando poderia ser também entendido como falha na interface metal/polímero), eventualmente com a ruptura $e$ arrancamento parcial da malha metálica nos casos em que a adesão da mesma em determinada área do substrato supera a resistência mecânica do inserto metálico, conforme esquematicamente ilustrado na Figura 2.24c. Este mecanismo de falha pode apresentar maiores valores de resistência ao cisalhamento devido à tensão $e$ energia extras demandadas pelo processo de fratura do metal.

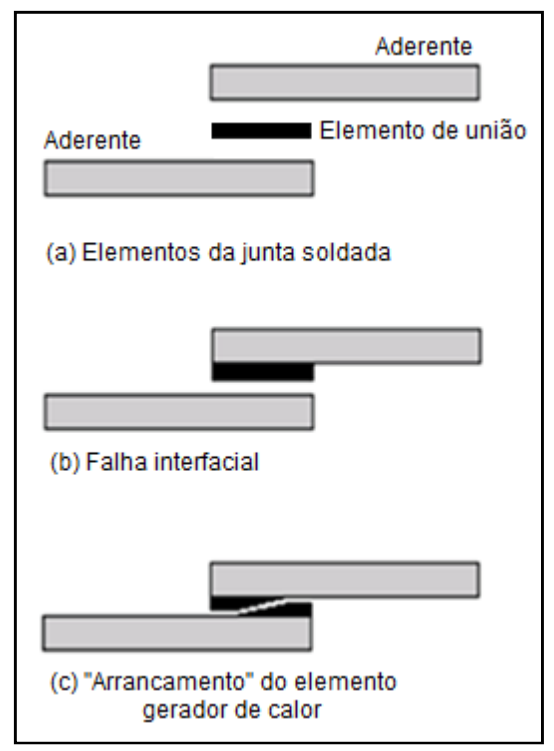

Figura 2.24 - Modos de falhas para juntas sobrepostas simples de cisalhamento contendo implante permanente resistivo (Adaptado de DUBÉ, 2007).

\subsection{Principais Normas Técnicas da American Society for Testing and Materials}

Dentre as normas existentes para o ensaio mecânico de juntas compósitas, podem-se citar seis como as mais relevantes quando levada em conta a análise de juntas do tipo sobreposta simples de cisalhamento ("single lap-joint').

Este tipo de configuração de junta para ensaio é em geral escolhido devido à facilidade de confecção dos espécimes e dos aparatos necessários para seu ensaio.

A norma ASTM-D3165 (2007) define a metodologia para determinação da propriedade de resistência ao cisalhamento de adesivos através do ensaio de juntas 
simples quando carregadas em tração, podendo ser usada para comparação dessa propriedade para diferentes tipos de adesivos. Esta norma chama atenção para os fatores que podem influenciar os resultados obtidos durante os ensaios, tais como condicionamento dos espécimes e, principalmente, o tratamento superficial realizado na área de colagem. A configuração de junta recomendada para este ensaio sugere um laminado com 1,62 mm de espessura, 25,4 mm de largura, 177,8 mm de comprimento além de $12,7 \mathrm{~mm}$ de sobreposição dos aderentes. Para este ensaio devem-se usar pequenas chapas metálicas para compensar a assimetria longitudinal da junta na hora de ensaiá-la e o carregamento pode ser aplicado através de garras hidráulicas auxiliadas ou não por pinos passantes nas extremidades do espécime.

A norma ASTM-D3166 (2012) é proposta para a determinação das propriedades de fadiga em cisalhamento para adesivos quando carregados em tração na configuração de juntas sobrepostas simples. Embora este método seja utilizado originalmente para juntas metal-metal, ele pode ser empregado para obterem-se propriedades de fadiga de adesivos aplicados em aderentes compósitos. Para este ensaio o equipamento deve ser capaz de aplicar carregamento cíclico senoidal através de carregamento ou deslocamento constante a uma razão de 1800 ciclos/minuto. A configuração da junta para aderentes não metálicos deve seguir pequenas alterações em relação às dimensões para aderentes metálicos, como, por exemplo, o incremento da espessura e da área de sobreposição para 6,4 mm e 12,7 $\mathrm{mm}$, respectivamente. Estas modificações sugeridas nas dimensões visam garantir que a falha ocorra no adesivo.

A preparação dos espécimes, como o corte, o acabamento e o condicionamento destes devem ser feitas de acordo com a norma ASTM-D1002 (2010). Esta norma delineia uma metodologia para determinar a resistência ao cisalhamento de juntas simples coladas, com aderentes metálicos, carregadas em tração. Esta normativa enfatiza que o resultado de resistência obtido através desta metodologia é fortemente influenciado pelas condições em que se estabelecem o processo empregado durante a colagem da junta, tais como, preparação da superfície onde será aplicado o adesivo, limpeza, umidade, pressão, temperatura ambiente, dentre outros fatores. Outra observação é quanto ao uso dos valores obtidos neste ensaio; A normativa ressalta que os valores de resistência obtidos neste ensaio são 
empregados com o objetivo de comparar diferentes tipos de adesivos e métodos empregados na preparação dos espécimes. Tais valores não podem ser empregados como valores de tensões admissíveis em projetos de juntas estruturais, pois não representam o comportamento real de uma estrutura, podendo, se aplicados, levar a falhas prematuras. Novamente, este tipo de ensaio é muito aplicado devido à simplicidade de fabricação dos corpos de prova.

A próxima norma, a ASTM-D4896 (2008), é um guia de como analisar os fatores que influenciam a resistência e outras medidas de tensão nos ensaios de juntas sobrepostas simples coladas. Embora as juntas simples sejam usadas para determinar a resistência ao cisalhamento, este valor acaba sendo definido como a resistência aparente ao cisalhamento, pois durante o ensaio a fratura é governada também por tensões trativas no adesivo e não por cisalhamento puro, e este mecanismo é agravado quando se emprega aderentes espessos devido ao incremento do momento secundário. Outros fatores, tais como o tamanho e a forma dos espécimes, as propriedades mecânicas dos aderentes, a presença de defeitos e tensões internas também afetam a determinação da tensão de cisalhamento. O texto também inclui a terminologia utilizada no escopo do ensaio mecânico de juntas sobrepostas simples. 


\section{MATERIAIS E MÉTODOS}

O presente trabalho de pesquisa apresenta a avaliação e a comparação das propriedades mecânicas de duas classes de juntas sobrepostas simples de cisalhamento de laminados sólidos compósitos, os quais diferem entre si quanto à natureza da matriz polimérica reforçada por fibras contínuas de carbono e quanto ao método empregado na união dos laminados. O primeiro tipo de junta é formado por laminados híbridos possuindo um núcleo robusto de fibras de carbono revestido com uma única camada externa de fibras de vidro, ambas as categorias de fibras reforçando uma matriz de polímero termoplástico (PPS - Poli-Sulfeto de Fenileno), sendo os aderentes (laminados) unidos através do processo de soldagem de fusão por resistência elétrica. O segundo tipo de junta é constituído por laminados de fibras de carbono fortalecendo uma matriz de resina epóxi termorrígida (EPX), sendo os aderentes (laminados) unidos através do processo de colagem com resina epoxídica na forma de filme adesivo. Deve-se enfatizar que os dois tipos de juntas analisadas, apresentam espessuras, volume de fibras do laminado e tipo de tecido diferente, assim como outros aspectos descritos neste capítulo. Contudo, este estudo foi realizado considerando os dois tipos de juntas como concorrentes diretas, ou seja, para aplicação em estruturas aeronáuticas com a mesma configuração e materiais analisados neste estudo.

\subsection{Tipos de corpos de provas e condições de danificação prévia dos espécimes}

Todos os corpos de prova do tipo junta sobreposta simples utilizados neste estudo foram manufaturados e fornecidos prontos para ensaios, sendo que a empresa fabricante não autorizou a divulgação de seu nome.

No primeiro tipo de junta, denominada junta termoplástica de PPS-C, o laminado ou aderente compósito rígido é formado por cinco camadas de tecido bidirecional 
$0 / 90^{\circ}$ de fibra de carbono com trama (" $5 H S$ weave") dispostas na configuração quase-isotrópica $[(0 / 90),( \pm 45),(0 / 90),( \pm 45),(0 / 90)]$, sendo a espessura da lâmina individual de $0,310 \mathrm{~mm}$ e sua densidade areal de $280 \mathrm{~g} / \mathrm{m}^{2}$, originalmente na forma semi-impregnada com polímero PPS. A cada face do laminado foi adicionada uma camada de tecido bidirecional $0 / 90^{\circ}$ de fibra de vidro com trama ("8HS weave") disposta na configuração $0 / 90^{\circ}$, sendo a espessura da lâmina individual de 0,240 $\mathrm{mm}$, também semi-impregnada com polímero PPS. O laminado completo exibiu, portanto, um arranjo de sete camadas dispostas na seqüência de empilhamento $\left(\left[\left(0 / 90^{\mathrm{FV}}\right) ;\left(0 / 90^{\mathrm{FC}}\right) ;\left( \pm 45^{\mathrm{FC}}\right) ;\left(0 / 90^{\mathrm{FC}}\right) ;\left( \pm 45^{\mathrm{FC}}\right) ;\left(0 / 90^{\mathrm{FC}}\right) ;(0 / 90)^{\mathrm{FV}}\right]\right)$, para uma espessura integral nominal final de 2,00 $\mathrm{mm}$ e um percentual médio volumétrico de fibras de reforço de $50 \%$. O laminado foi manufaturado segundo a técnica de compressão a quente pela empresa TenCate Advanced Composites ${ }^{\circledR}$.

A união dos laminados PPS-C para a formação da junta sobreposta simples de cisalhamento foi realizada por intermédio do processo de soldagem por resistência, elétrica, tendo-se como elemento gerador de calor uma malha metálica de aço inoxidável recoberta por filme de PPS em ambos os lado (a descrição do processo de soldagem por resistência elétrica é detalhada no item 2.3.2 do Capítulo 2 deste texto). A Figura 3.1a mostra as dimensões finais de um corpo de prova do tipo junta sobreposta simples soldada por fusão.

O segundo tipo de junta, denominada junta termorrígida de EPX-C, o aderente ou laminado compósito sólido é constituído por oito camadas de tecido de fibra de carbono na configuração bidirecional 0/90ำ e trama simples ("plain-weave"), com espessura da lâmina individual de 0,205 mm, densidade de $193 \mathrm{~g} / \mathrm{m}^{2}$, préimpregnadas com resina termorrígida epóxi tenacificada com partículas de elastômero termoplástico. O arranjo de camadas no laminado é $[(0 / 90),( \pm 45),(0 / 90),( \pm 45) 2,(0 / 90),( \pm 45),(0 / 90)]$, sendo o mesmo consolidado em autoclave via bolsa de vácuo e exibindo uma espessura integral final nominal de $1,75 \mathrm{~mm}$ e um percentual médio volumétrico de fibras de reforço de $60 \%$.

A união dos laminados para a geração da junta sobreposta simples de cisalhamento foi executada através do processo de colagem, utilizando adesivo epoxídico suportado por trama de filamento polimérico de modo a restringir seu vazamento pelas bordas da junta e o conseqüente empobrecimento da linha de 
união quanto ao agente de adesão. A Figura 3.1b mostra as dimensões finais para o corpo de prova (CDP) do tipo junta sobreposta simples colada.
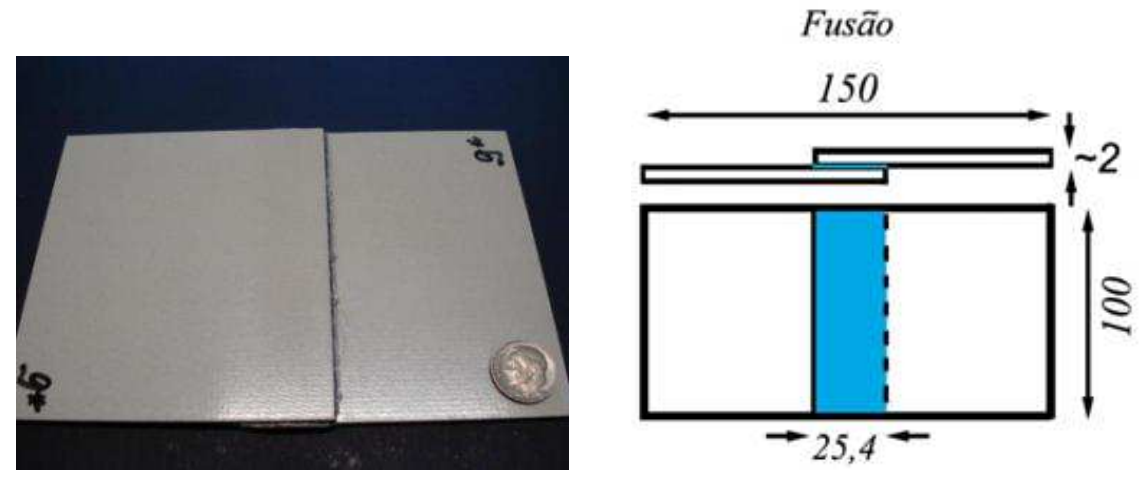

(a)
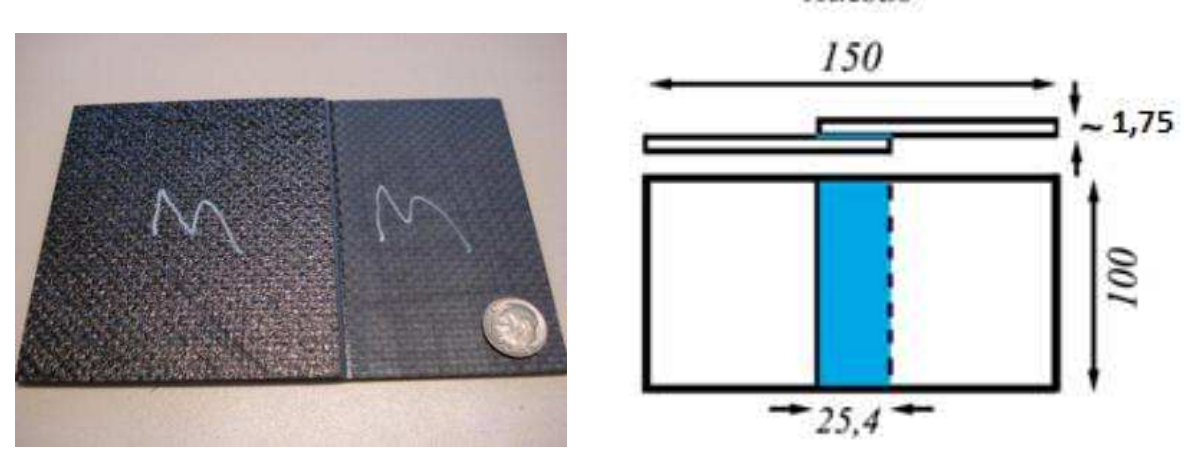

(b)

Figura 3.1 - Aspectos e dimensões finais do CDP termoplástico soldado (a), e do CDP termorrígido colado (b).

Ambas as classes de juntas sobrepostas simples de cisalhamento confeccionadas em laminados sólidos compósitos, respectivamente, termoplástico (PPS-C) e termorrígido (EPX-C) foram inicialmente divididas nos seguintes grupos: (i) virgem, (ii) simplesmente impactadas, (iii) "simplesmente condicionadas", (iv) "impactadas + condicionadas", (v) "simplesmente fadigadas", (vi) "impactadas + fadigadas", e (vii) "impactadas + condicionadas + fadigadas".

A descrição detalhada de cada um destes grupos é como segue:

CDPs "virgens" (V): são aqueles que foram mantidos em condições normais de laboratório (temperatura de $25^{\circ} \mathrm{C}$ e umidade relativa do ar de $65 \%$ ), não sendo, portanto, previamente submetidos a qualquer condicionamento 
ambiental e nem a carregamentos mecânicos, sejam estes de impacto e/ou em fadiga.

CDPs "simplesmente impactados" (I): correspondem àqueles que foram mantidos em condições normais de laboratório e, posteriormente, submetidos a impacto único transversal (na direção da espessura da junta) com energia de $10 \mathrm{~J}$ aplicado no centro da área sobreposta soldada (CDPs da classe PPS-C) e colada (da classe EPX-C). Os ensaios de impacto foram conduzidos nas dependências do ITA - Instituto Tecnológico de Aeronáutica de São José dos Campos - SP.
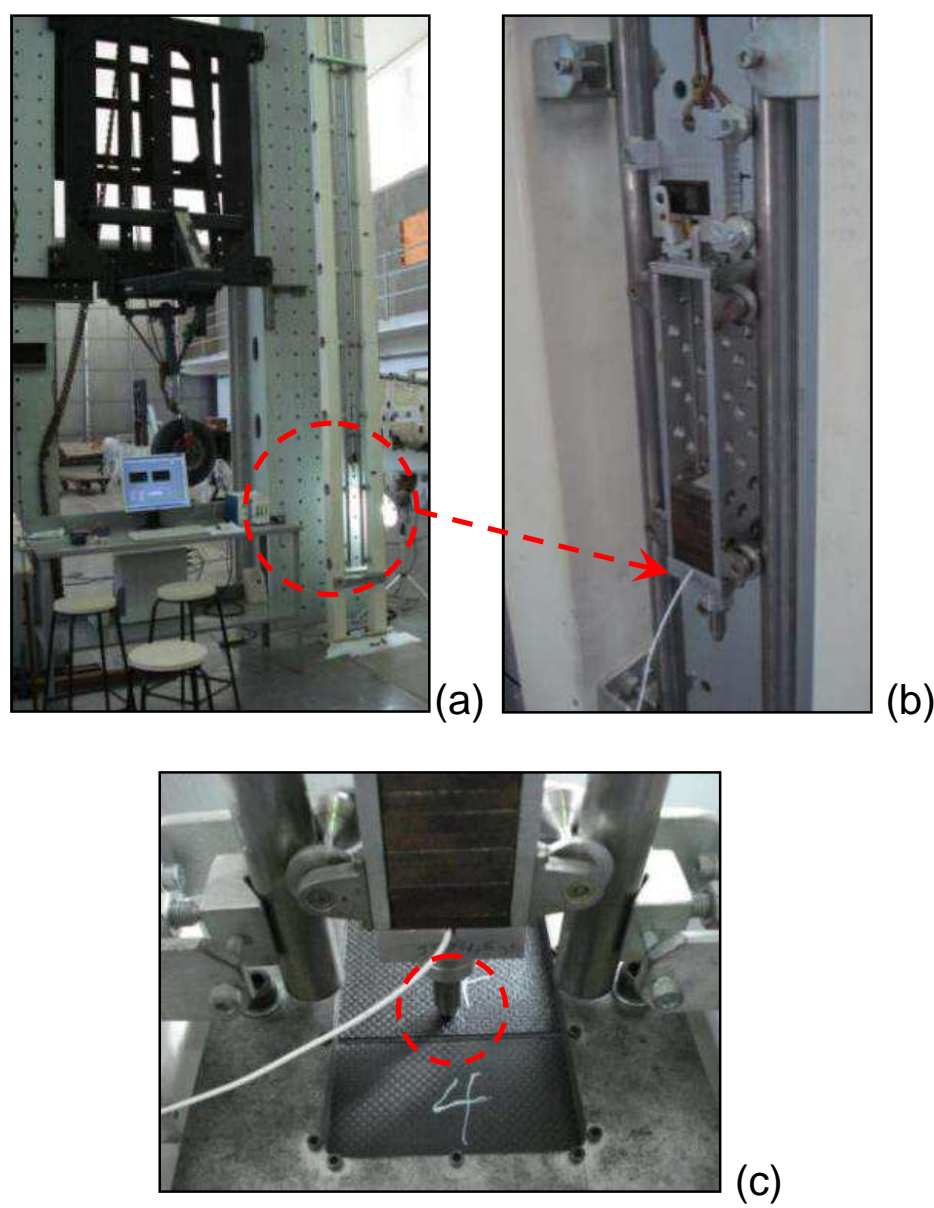

Figura 3.2 - (a) Torre de impacto totalmente computadorizada para aquisição de sinais e processamento de dados e semi-automatizada no que se refere a movimentação vertical do impactador e seu mecanismo anti-rebote; (b) Detalhes do impactador e da correspondente ponteira metálica; (c) Detalhes da base de fixação do CDP, indicando-se com um círculo vermelho tracejado o ponto de contato entre a ponteira e a zona de sobreposição de uma junta colada de EPX-C. 
Empregou-se na tarefa uma torre de impacto ("drop weight tower") projetada para ensaios segundo a norma ASTM-D7136-05, que trata da medida da resistência a danos por impacto em laminados sólidos de matriz polimérica fortalecida por fibras contínuas de alto desempenho. O equipamento empregado consiste em um impactador com massa fixa de $1,5 \mathrm{~kg}$, cuja ponteira de aço possui formato semiesférico e um diâmetro de $10 \mathrm{~mm}$, sendo, no caso em questão, utilizado uma velocidade de impacto de $3,65 \mathrm{~m} / \mathrm{s}$ (correspondendo, portanto, a uma energia de 10 J). A Figura 3.2 mostra uma vista geral da torre de impacto do ITA e detalhes do trem de carregamento dinâmico e da base de fixação especialmente projetada e construída para assentar e prender os CDPs de geometria retangular com assimetria devida à sobreposição da junta.

O nível de energia de $10 \mathrm{~J}$ foi selecionado para ambas as classes de juntas, pois, sob um impacto com energia de 5 Joules nenhuma delas exibiu quaisquer sinais de danos passíveis de uma identificação visual (violando assim o critério de "BVID - Barely Visible Impact Damage"), enquanto que, sob um impacto com energia de 15 Joules a junta termoplástica mostrou sinais evidentes da danificação em ambas as suas faces (frontal e posterior, respectivamente), conforme mostra a Figura 3.3, de sorte que, também nestas condições, o critério de BVID também não foi satisfeito.

Desta forma, um valor intermediário de energia de impacto àqueles dois extremos anteriormente citados (respectivamente 5 e 15 Joules), ou seja, 10 Joules, foi considerado como ideal para fins de garantir-se, para ambas as classes de juntas, a existência de danos por impacto na área de sobreposição, junção ou união das mesmas, mas, ao mesmo tempo, que eles (danos) não fossem claramente evidenciados numa rápida inspeção visual (diferentemente do que é verificado na Figura 3.3).

Assim, a energia de 10 Joules foi adotada como valor padrão para a execução dos ensaios de impacto por queda de peso ("drop weight impact test") em quaisquer das situações avaliadas no presente estudo para as duas classes de juntas. 

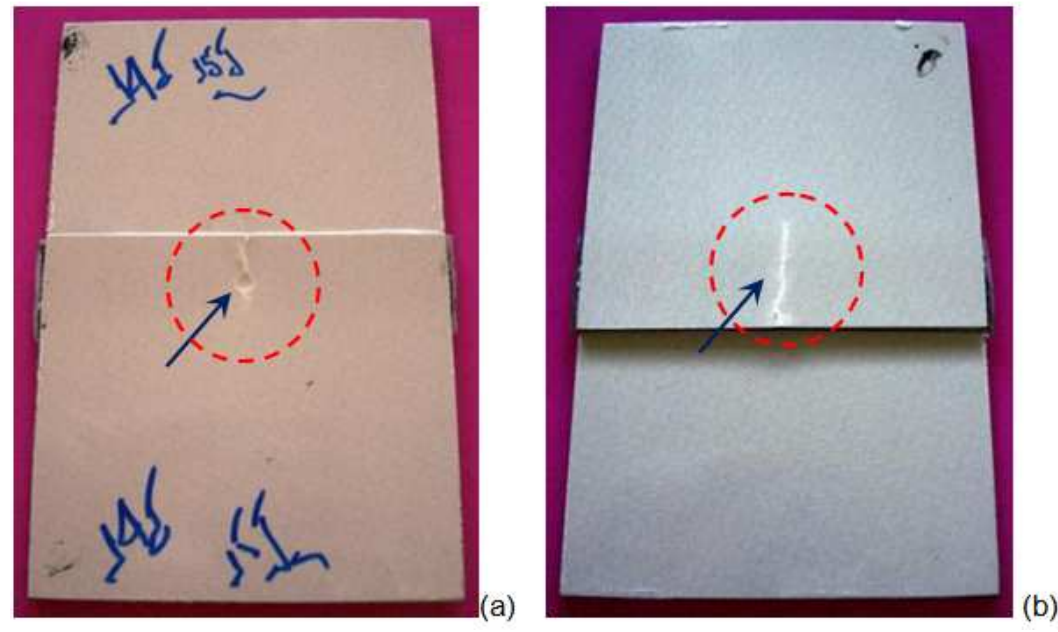

Figura 3.3 - Vistas da face impactada (a), e da face posterior (b) da junta termoplástica soldada PPS-C, em que fica evidente a danificação causada pelo carregamento dinâmico com energia de 15 Joules.

> CDPs "simplesmente condicionados" (C): referem-se àqueles que foram mantidos em condições higrotérmicas, ou seja, submetidos simultaneamente a relativamente alta temperatura e elevadíssima umidade relativa, conforme descrito abaixo.

Para o condicionamento higrotérmico, os CDPs foram dispostos em uma câmara completamente vedada, com paredes confeccionadas em policarbonato, e expostos à temperatura de $80^{\circ} \mathrm{C}$ sob uma umidade relativa de $100 \%$ por um tempo de 1.000 horas (42 dias), seguindo as diretrizes estabelecidas nas normas ASTM-C 562-91 e ASTM 5229-12, as quais indicam que os valores acima mencionados são satisfatórios para que uma condição de saturação seja alcançada para os laminados compósitos poliméricos de interesse.

Vapor d'água foi gerado por intermédio de três vaporizadores comercialmente disponíveis (Figura 3.4), os quais proporcionavam, através do controle da tensão aplicada aos mesmos (110 ou 220 Volts), o acurado controle da temperatura interna do sistema, e, consequentemente, dos espécimes nele contidos, sendo que todos foram igualmente expostos àquelas condições pré-estabelecidas quanto à temperatura, umidade e tempo de residência.

As juntas foram dependuradas verticalmente por presilhas de aço galvanizado (de modo a minimizar efeitos de corrosão e a conseqüente contaminação dos 
espécimes pelos eventuais subprodutos da eventual reação eletroquímica, a qual foi, em alguma extensão, favorecida pelo contato do metal com as fibras de carbono), as quais estavam vinculadas mecanicamente ao teto da câmara. Foi guardada uma distância entre os bocais dos vaporizadores e a porção inferior dos espécimes de maneira a minimizar uma ação mais danosa de eventuais fluxos turbulentos de vapor d’água na saída dos vaporizadores.

A temperatura interna da câmara foi monitorada via termômetro analógico, cujo bulbo foi posicionado exatamente na altura média das juntas dependuradas na parede superior da câmara (Figura 3.4).
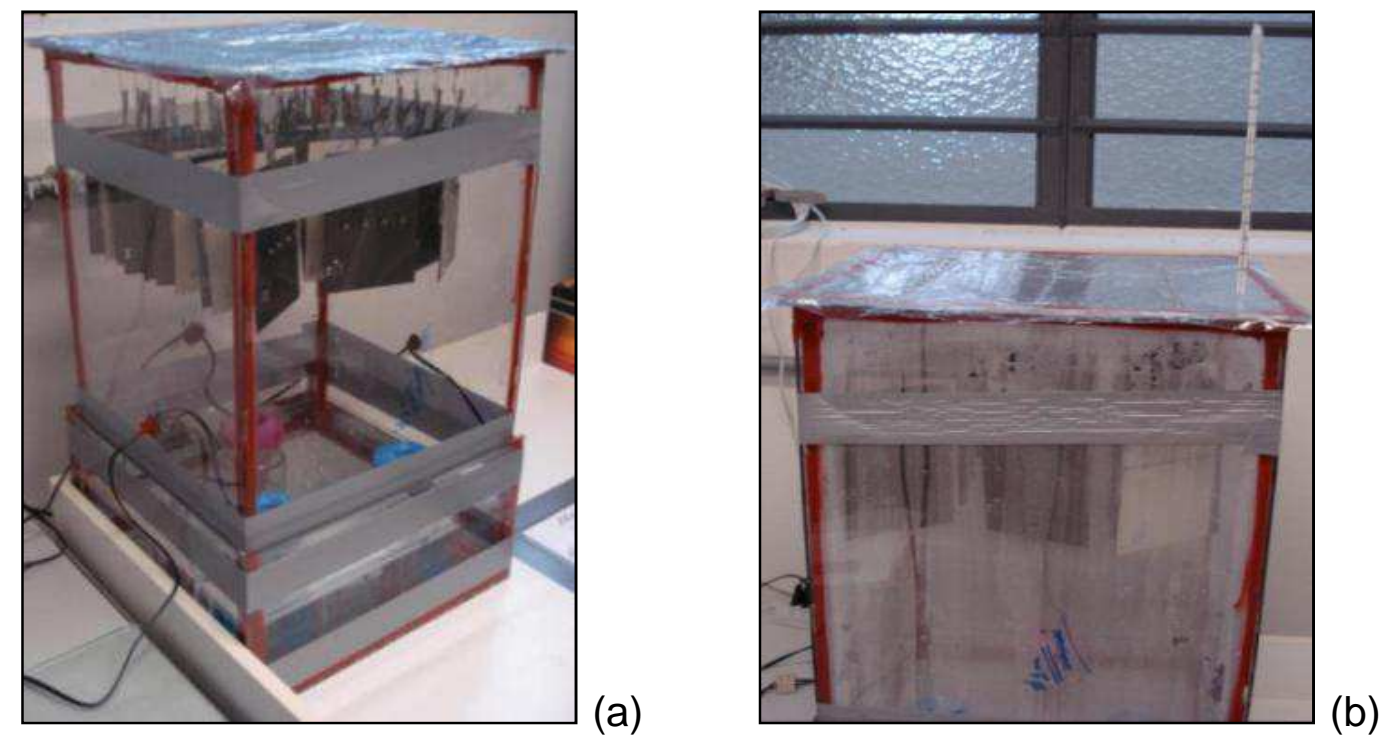

Figura 3.4 - (a) Três vaporizadores parcialmente imersos em banho aquoso na porção inferior da câmara vedada confeccionada com chapas de policarbonato coladas com adesivo de silicone, e (b) Termômetro analógico situado na porção superior da câmara climática, com o bulbo de mercúrio posicionado na altura média das juntas dependuradas.

Uma coluna d'água (água corrente residencial) para imersão parcial dos vaporizadores foi mantida constante durante toda a execução do condicionamento ambiental. Haja vista a natural perda de água para o ambiente externo, apesar da vedação suficientemente boa da câmara, obtida pelo extensivo uso de adesivo a base de silicone, água era periodicamente adicionada ao recipiente por meio de uma seringa de grande porte através do orifício em que se encontrava o termômetro, de modo a manter a altura da coluna d’água em seu nível adequado, qual seja, próximo à porção inferior dos bocais dos vaporizadores. Estes últimos foram mantidos na 
posição vertical com seus bocais apoiados em recipientes comerciais de vidro, cujos tampos inferiores foram extraídos por corte com risco diamantado segundo uma geometria que permitisse o ingresso da água nesses recipientes cilíndricos, de modo que a mesma pudesse ser subseqüentemente vaporizada.

> CDPs "impactados + condicionados" (I+C): são aqueles que foram mantidos inicialmente em condições normais de laboratório, subseqüentemente submetidos a impacto único transversal de $10 \mathrm{~J}$ e, em seguida, expostos a condicionamento higrotérmico. Para esses CDPs os ensaios de impacto e o condicionamento ambiental foram realizados conforme descrição prévia no texto.

CDPs "simplesmente fadigados" (F): correspondem àqueles que foram mantidos em condições normais de laboratório e, na seqüência, submetidos unicamente a ensaios de fadiga compressiva, estes realizados nas dependências do Laboratório de Estruturas Aeronáuticas da Universidade de Bath-UK, cujos procedimentos são reportados mais à frente neste texto.

D CDPs "impactados + fadigados" (I+F): referem-se àqueles que foram mantidos inicialmente em condições normais de laboratório, sendo posteriormente submetidos a impacto único transversal de $10 \mathrm{~J}$, e, na seqüência, sujeitos ao ensaio de fadiga compressiva. Para esses CDPs as condições impostas na impactação e nos ciclos de fadiga foram, respectivamente, conforme descritas anteriormente e subseqüentemente neste texto.

CDPs "condicionados + fadigados" $(\mathbf{I}+\mathbf{C}+\mathrm{F})$ : são aqueles que foram submetidos a impacto único transversal de $10 \mathrm{~J}$, e na seqüência expostos ao condicionamento higrotérmico e, em seguida, submetidos a carregamento em fadiga compressiva. Para esses CDPs as condições impostas na impactação, no condicionamento ambiental e impostas nos ciclos de fadiga, 
respectivamente, conforme descritas anteriormente e subseqüentemente neste texto.

A escolha do carregamento em fadiga compressiva advém da susceptibilidade dos laminados compósitos finos, e, obviamente, de suas correspondentes juntas compósitas, à compressão no plano, em especial na existência de danos causados por impactos transversais, particularmente as delaminações, favorecendo assim uma falha final (ou, ao menos, a operacionalização de mecanismos de falha) do tipo flambagem. Some-se a isso a sensibilidade dos compósitos de matriz polimérica aos ambientes agressivos encontrados em serviço (por exemplo, aqueles exibindo altos níveis de umidade e relativamente alta temperatura). Estes fatores degradativos de naturezas mecânica, física, química, ou mesmo eletroquímica (caso seja considerado, na junta termoplástica PPS-C, o eventual contato direto entre o implante resistivo metálico e as fibras de reforço de carbono), requerem estudos (mesmo que se empregando ambientes simulados e ensaios conduzidos em escala laboratorial) objetivando estabelecerem-se limites mínimos de desempenho residual de juntas compósitas, de modo a assegurar a integridade estrutural das aeronaves que se utilizam destes elementos de conexão, permitindo estabelecerem-se parâmetros e critérios mais realísticos de projeto estrutural para operação segura (aeronavegabilidade), conforme enfatizado por RHEAD et al. (2010).

As juntas foram ensaiadas em fadiga compressiva no plano à temperatura e condições ambiente, nas condições de: (i) virgem (V), (ii) simplesmente impactadas (I), e (iii) impactadas e condicionadas $(I+C)$, empregando-se o dispositivo ilustrado na Figura 3.5, e tendo-se como referências as normas ASTM-D1002-02, D3163-05, D3165-02, D3410-05, D4896-05, D5656-03, D5868-05 e D6641-05.

Após os CDPs terem sido submetidos à fadiga compressiva, e considerando-se a descrição anteriormente fornecida para cada condição inicial dos espécimes, estes passaram a ser então denominados, respectivamente: (i) "simplesmente fadigado (F)", (ii) "impactado + fadigado" ( $\mathrm{I}+\mathrm{F})$, e (iii) "impactado + condicionado + fadigado" $(\mathrm{I}+\mathrm{C}+\mathrm{F})$. 


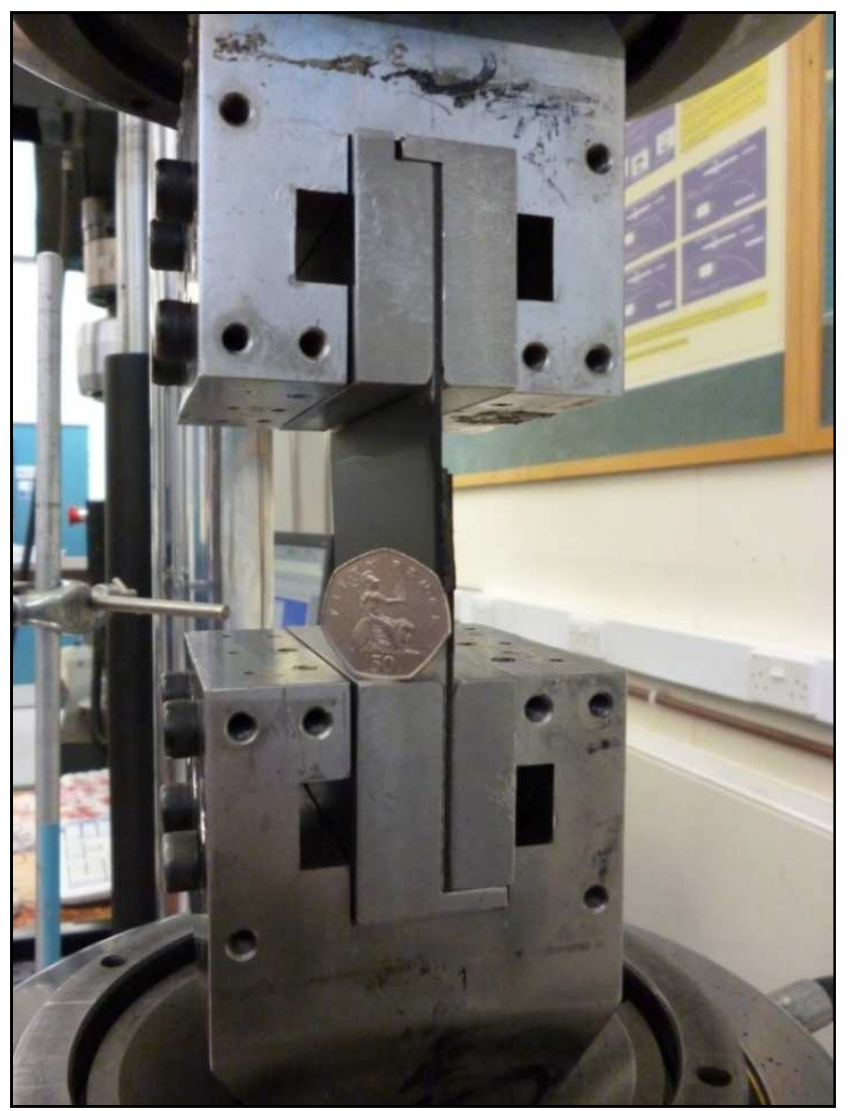

Figura 3.5 - Dispositivo de fadiga compressiva no plano, montado no laboratório de Estruturas Aeronáuticas da Universidade de Bath-UK.

Foram utilizados nestes ensaios realizados na Universidade de Bath-UK, um sistema servo-hidráulico da Instron ${ }^{\circledR}$ totalmente automatizado e informatizado com capacidade máxima de carga de $100 \mathrm{kN}$.

Foram inicialmente realizados ensaios prévios de compressão no plano, ao qual foi aplicada de modo lento (quase-estático com velocidade de $0,35 \mathrm{~mm} / \mathrm{min}$.) e monotônico às duas classes de juntas compósitas, de modo a identificar, para várias condições das mesmas, quais sejam, $\mathrm{V}, \mathrm{I}, \mathrm{e} \mathrm{I}+\mathrm{C}$, uma carga compressiva comum a elas que pudesse ser aplicada como força compressiva máxima cíclica sem que ocorresse falha catastrófica para um número de ciclos de 6E4. Esta ciclagem consiste, em geral, na vida em fadiga definida em projeto para jatos regionais. A imposição de uma condição de não-falha catastrófica dos CDPs, durante o carregamento em fadiga teve como base a necessidade de se mensurar a resistência residual (ou seja, determinar a tolerância a danos) das mesmas, em suas diversas condições de pré-danificação, por intermédio de ensaio quase-estático de 
flexão em quatro pontos, assim como através de ensaio de resistência ao cisalhamento interlaminar, a serem descritos na seqüência do texto.

O valor da carga assim determinada (de $12,5 \mathrm{kN}$ ) foi integralmente convertido em tensão de membrana compressiva remota, bruta, nominal, ou de engenharia (62,5 MPa), haja vista que nenhum artifício foi adotado para considerarem-se efeitos de sobreposição dos laminados compósitos unidos por soldagem (PPS-C) e colagem (EPX-C) e, conseqüentemente, o desenvolvimento de tensões de natureza fletiva nas juntas.

Empregou-se uma razão de cargas $\mathrm{R}$ igual a 10 (-12,5 / -1,25 KN), a máxima possível de modo a impingir danos por fadiga às juntas num tempo relativamente curto de experimento, porém evitando instabilidades mecânicas do sistema formado pelo CDP e as garras hidráulica superior e inferior (Figura 3.5). A forma originalmente escolhida de aplicação dos ciclos de carregamento em amplitude constante de carga, ou tensão, foi a senoidal. Optou-se por uma freqüência de aplicação dos ciclos de carregamento de $5 \mathrm{~Hz}$, suficientemente elevado para viabilizar a condução dos ensaios em termos de tempo despendido no processo, e baixo o necessário para evitar sobreaquecimento e efeitos térmicos indesejáveis às juntas.

\subsection{Ensaio de resistência residual via flexão sob quatro pontos}

As juntas sobrepostas simples de cisalhamento concorrentes, PPS-C e EPX-C, conforme definidas anteriormente, foram ensaiadas em flexão monotônica sob quatro pontos (F4P), à temperatura e condições ambiente, nas diversas condições: $V, C, I, I+C, F, I+F, I+C+F$, tendo-se como referência a norma ASTM-D7264-07.

Um exemplo da condução de um ensaio monotônico quase-estático em F4P é ilustrado na Figura 3.6. 


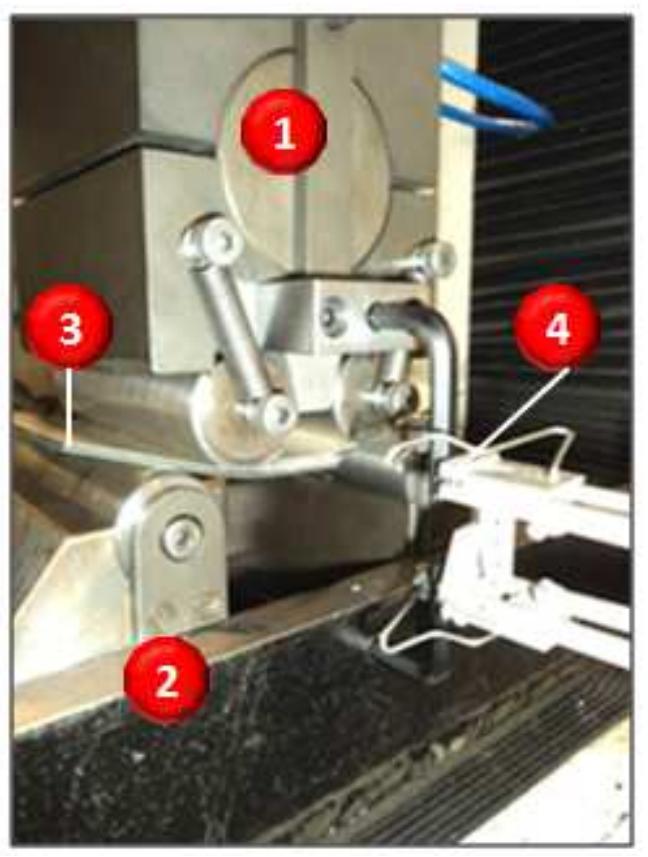

1-Trem de carga

2-Base para F4P

3- CDP

4- Extensômetro

Figura 3.6 - Sistema de F4P em operação, em que se observa o extensômetro que mensura precisamente a deflexão máxima experimentada pela junta durante o carregamento fletivo monotônico quase-estático.

Devido à assimetria natural das juntas sobrepostas simples, foi necessário colocar uma "canaleta" em um dos roletes do dispositivo de aplicação de carga (superior) e outra num dos roletes da base inferior de modo a haver compensação da assimetria e o ensaio transcorrer em perfeito alinhamento horizontal. Também, devido à diferença de espessura entre os laminados (aderentes) que formavam as juntas termoplástica de PPS-C e termorrígida de EPX-C, as canaletas foram usinadas com espessuras diferentes, sendo de 1,8 mm para o PPS-C e de 2,2 mm para o EPX-C.

Os dois roletes da base inferior e os dois do dispositivo superior de aplicação de carga tinham diâmetro de $30,8 \mathrm{~mm}$, e as distâncias entre os roletes de apoio inferiores e entre os roletes superiores de aplicação de carga foram de, respectivamente, $102 \mathrm{~mm}$ e $45 \mathrm{~mm}$. A velocidade de deflexão do CDP na linha central do dispositivo de carregamento, onde se desenvolve a máxima taxa de deslocamento, foi fixada em $2 \mathrm{~mm} / \mathrm{min}$.

Os valores médios de resistência máxima em flexão e de rigidez das juntas PPSC e EPX-C, além dos seus respectivos desvios-padrão, foram calculados em planilha Microsoft-Excel ${ }^{\circledR}$ e plotados na forma de gráficos de barras para cada classe 
de junta nas suas diversas condições de danificação, assim como plotados conjuntamente de modo a permitir o confronto geral dos resultados obtidos.

\subsection{Ensaio de resistência residual ao cisalhamento interlaminar}

O ensaio de resistência ao cisalhamento interlaminar ("interlaminar shear stress" - ILSS) de espécimes extraídos da região de sobreposição de algumas das juntas termoplástica PPS-C e termorrígida EPX-C visou também, assim como o ensaio de F4P, avaliar mecanicamente a qualidade dos respectivos processos de união por soldagem e colagem, empregando-se nesta caracterização as diretrizes da norma ASTM-D2344-06. Foram empregados neste ensaio CDPs em apenas duas condições, quais sejam, virgem (V) e simplesmente impactado (I).

Cada CDP ensaiado teve a área de soldagem, ou colagem cortada no sentido longitudinal de modo a se gerarem nove espécimes possuindo 9,0 $\mathrm{mm}$ de largura e 25,4 de comprimento, conforme ilustrado na Figura 3.7.

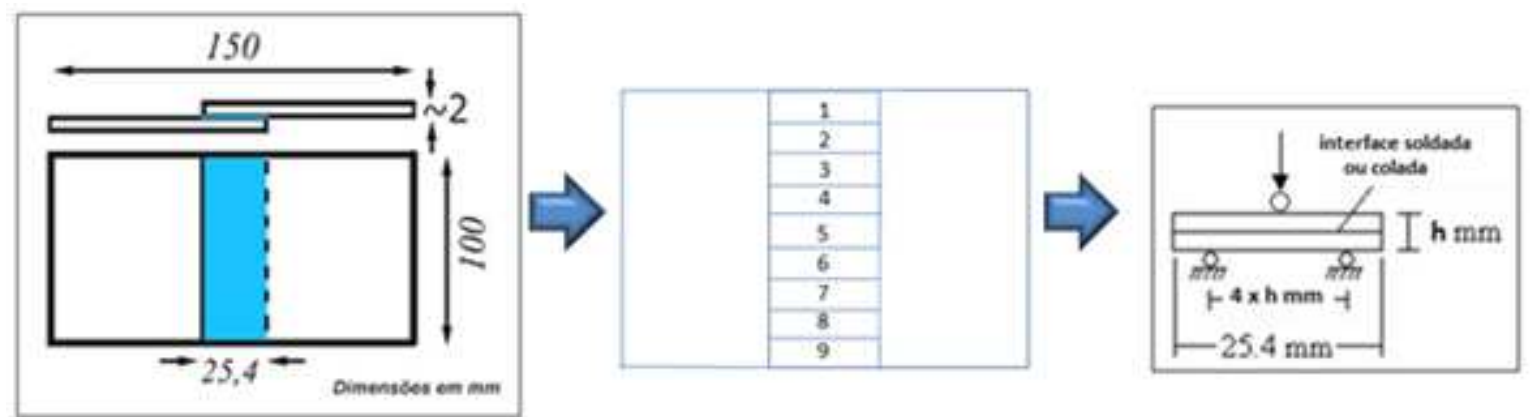

Figura 3.7 - Esquemático da extração de espécimes ILSS a partir da área de sobreposição de uma junta PPS-C, e configuração do carregamento mecânico dos mesmos.

Para a realização dos ensaios de ILSS, foi utilizada uma máquina EMIC ${ }^{\circledR}$ modelo DL-10000 com célula de carga de 10 kN. Na base do dispositivo de ensaio a distância entre os dois roletes de apoio foi de quatro vezes a espessura do espécime (ou seja, o vão empregado foi de $16 \mathrm{~mm}$ para espécimes de PPS-C e de $14 \mathrm{~mm}$ no caso dos EPX-C), sendo o diâmetro destes roletes de $3 \mathrm{~mm}$. Para o rolete central do 
trem de carga o diâmetro utilizado foi de $6 \mathrm{~mm}$. A velocidade de ensaio, em termos de taxa de deslocamento do rolete central, foi fixada em $1 \mathrm{~mm} / \mathrm{min}$. O dispositivo de ensaio ILSS é ilustrado na Figura 3.8.

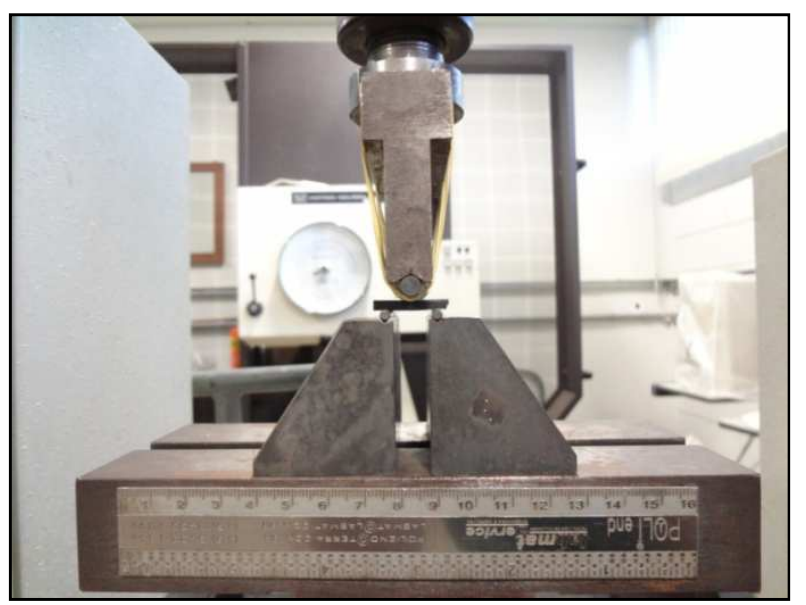

Figura 3.8 - Dispositivo utilizado nos ensaios ILSS de resistência ao cisalhamento interlaminar das juntas compósitas PPS-C e EPX-C.

O valor de tensão máxima atingida no ensaio ILSS foi obtido a partir da equação 3.1, fornecida pela norma ASTM-D2344 e expressa abaixo:

$$
T=0.75 \times \frac{P}{b \times h}
$$

onde:

$T=$ Resistência da amostra ao cisalhamento interlaminar (MPa)

$P=$ carga máxima atingida durante o ensaio $(\mathrm{N})$

$b=$ largura do espécime $(\mathrm{mm})$

$h=$ espessura do espécime $(\mathrm{mm})$

Os valores médios da tensão de falha, além dos respectivos desvios-padrão, foram calculados em planilha Microsoft-Excel ${ }^{\circledR}$ e plotados na forma de gráficos de barras individuais para os espécimes extraídos das juntas nas condições "virgem" e 
"impactada", confeccionadas a partir de laminados termoplástico PPS-C e termorrígido EPX-C, respectivamente.

\subsection{Estereoscopia}

A análise estereoscópica foi realizada sobre a superfície de fratura dos espécimes após ensaios para determinação da sua resistência residual em F4P. O objetivo da análise foi observar, na superfície de fratura, indícios tanto de qualidade quanto de defeitos originados durante os processos de soldagem do PPS-C e colagem do EPX-C, respectivamente, assim como danos oriundos dos tratamentos previamente introduzidos nos espécimes, seja por impacto e/ou condicionamento higrotérmico e/ou fadiga, anteriormente, portanto, aos ensaios de resistência residual em F4P. Os micromecanismos de falha/fratura operativos nos espécimes durante todos os estágios aos quais os mesmos foram submetidos, conforme acima mencionados, foram tentativamente identificados e caracterizados com base nos imagens obtidas.

Empregou-se na estereoscopia um equipamento ZEISS ${ }^{\circledR}$ modelo Discovery V8 equipado com câmera digital pertencente ao Departamento de Engenharia de Materiais da EESC-USP.

\subsection{Microscopia óptica de reflexão de luz}

Com o objetivo de avaliar novamente indícios de qualidade e de defeitos dos processos de soldagem do PPS-C e de colagem do EPX-C, respectivamente, assim como identificar e caracterizar os danos causados por impacto e/ou envelhecimento ambiental induzidos previamente a ensaios de F4P, estes precedidos ou não por fadiga compressiva no plano da junta sobreposta simples de cisalhamento, seções de corte materialograficamente preparadas segundo diversas posições e orientações 
de planos de observação ao longo das áreas de sobreposição das juntas unidas por soldagem e colagem, respectivamente, foram inspecionadas em microscópio óptico de reflexão de luz.

Foram empregadas no preparo das seções de observação materialográfica as melhores práticas e materiais de consumo especificamente dedicados ao corte, 0 embutimento, o lixamento e o polimento de laminados compósitos de matriz polimérica reforçados com fibras continuas de alto desempenho, de forma a revelar as nuances mais detalhadas das amostras.

Para a obtenção das imagens foi utilizado o microscópio óptico ZEISS ${ }^{\circledR}$ modelo AXIO Lab. A1. Como este modelo é equipado com câmera digital, foi possível fotografar e arquivar as imagens em formato digital com altíssima resolução espacial.

\subsection{Microscopia eletrônica de varredura}

Após os ensaios de F4P foram selecionadas algumas posições de interesse sobre as superfícies de fratura assim criadas, sendo recortadas as amostras para observação destas áreas ao microscópio eletrônico de varredura (MEV) com o objetivo principal de avaliar a interação resina termoplástica de PPS/malha metálica resistiva de aço inoxidável (especificamente para a junta termoplástica soldada), assim como para caracterizar e documentar os mecanismos de falha e fratura envolvendo as fibras, a matriz polimérica e as correspondentes interfaces. No caso da junta termorrígida colada, o objetivo principal foi avaliar a interação filme epóxi e malha polimérica utilizada no filme adesivo de colagem para controle dimensional da espessura da interface de junção, interação fibra/matriz, além de caracterizar os mecanismos de falha na interface de união da junta.

$\mathrm{Na}$ tarefa, foram utilizados dois MEVs, um pertencente ao Instituto de Química de São Carlos (IQSC-USP), marca ZEISS LEO 440 (Cambridge, England) com detector OXFORD e modelo 7060 operando com feixe de elétrons de $20 \mathrm{kV}$, onde o preparo das amostras se deu com o recobrimento da superfície de interesse com 
uma camada de ouro com $6 \mathrm{~nm}$ de espessura, empregando-se para isso um metalizador Coating System BAL-TEC ${ }^{\circledR}$ MED 020, sendo as amostras posteriormente mantidas em dessecador até o momento de análise. As condições de metalização foram: pressão na câmara $=2,00 \times 10^{-2} \mathrm{mbar}$; corrente $=60 \mathrm{~mA}$; taxa de deposição $0,60 \mathrm{~nm} / \mathrm{s})$.

O outro MEV utilizado foi no Laboratório de Microscopia e Microanálise do Centro de Tecnologia de Materiais Híbridos (LMM/CTMH/USP) em um equipamento Inspect F50 ( $\mathrm{FEl}$, the Netherlands), operando com feixe de elétrons de $5 \mathrm{kV}$. As amostras foram recobertas com cerca de $30 \mathrm{~nm}$ de ouro em um metalizador Q 150R ES ( Quorum Technologies, England) e mantidas em dessecador até o momento da análise. 


\section{RESULTADOS E DISCUSSÕES}

Os resultados e discussões são apresentados neste capítulo, iniciando-se pelos ensaios mecânicos de flexão sob quatro pontos (F4P), análise dos modos de falha via inspeção visual, estereoscopia, microscopia óptica e eletrônica de varredura, seguida dos ensaios de tensão de cisalhamento interlaminar (ILSS).

\subsection{Ensaios de carga máxima em F4P}

Os ensaios de flexão sob quatro pontos (F4P) foram realizados para as juntas soldadas e coladas previamente submetidas a condicionamento higrotérmico, carregamento de impacto e virgem, conforme descrito no capítulo 3. Na apresentação dos resultados usou-se a denominação PPS-C para a junta soldada e EPX-C para a junta colada, seguidos de seu número de identificação assim como sua denominação de acordo com as Tabelas A1 e A2 (fornecidas em Apêndices).

Iniciando pela análise dos corpos de prova (CDPs) de PPS-C através do gráfico de barras plotado na Figura 4.1 (os correspondentes pontos de dados são listados na Tabela A.1 em Apêndices), ilustrando a força máxima obtida no ensaio de F4P para cada condição dos CDPs de PPS-C

Os gráficos da Figura B.1 (em Apêndices) evidenciam que os CDPs para todas as condições de ensaio exibiram comportamento linear na primeira parte da curva, seguido de comportamento não linear pouco antes de atingir o ponto de ruptura. Este comportamento não linear na parte final da curva pode ser atribuído a ductibilidade da resina Poli-Sulfeto de Fenileno (PPS) e principalmente a progressão de danos na área da soldagem com o aumento da carga. 


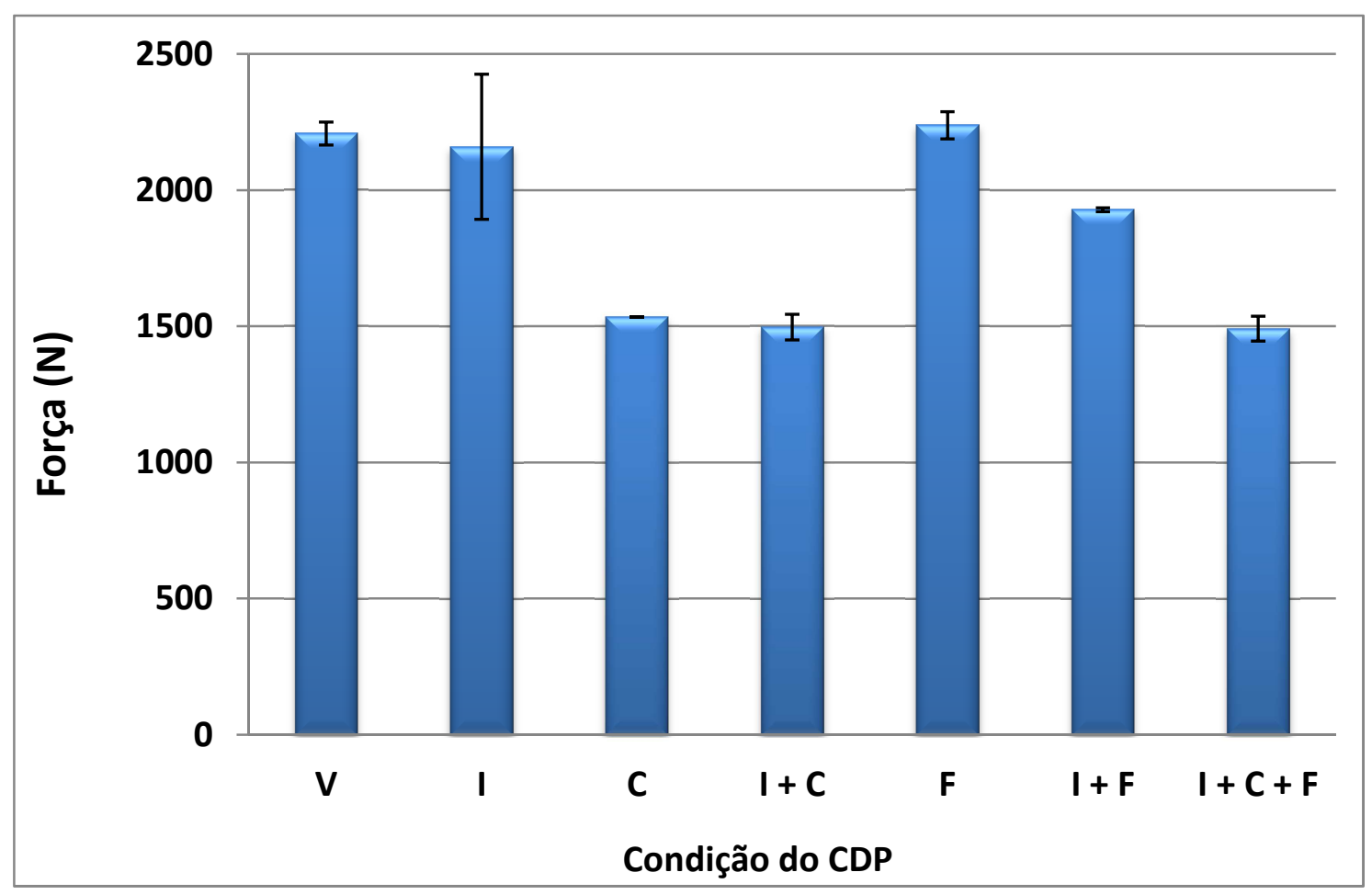

Figura 4.1 - Gráfico dos valores médios de força máxima para os CDPs de PPS-C nas condições Virgem (V), Impactado (I), Condicionado (C), Impactado + Condicionado $(I+C)$, Fadigado $(\mathrm{F})$, Impactado + Fadigado $(\mathrm{I}+\mathrm{F})$ e Impactado + Condicionado + Fadigado $(\mathrm{I}+\mathrm{C}+\mathrm{F})$.

As principais conclusões para as juntas PPS-C com base nos resultados da Figura 4.1 podem ser assim listadas:

$\checkmark$ A simples aplicação de impacto único de $10 \mathrm{~J}$ não afetou significativamente a resistência mecânica residual da junta termoplástica soldada;

$\checkmark$ O simples condicionamento ambiental ocasionou uma redução aproximada de $30 \%$ na resistência desta junta, não obstante a relativamente baixa absorção de umidade nesta classe de junta quando condicionada higrotermicamente a partir do estado virgem (apenas $1 / 3$ da umidade absorvida pela junta colada virgem). Considerando-se as elevada resistência química e térmica intrínsecas da matriz termoplástica, há de se levar em conta a possibilidade de o elemento metálico de implante ter, direta ou indiretamente, comprometido o desempenho mecânico da junta, como por exemplo, através da expansão térmica diferencial do metal de implante relativamente à resina polimérica envoltória, causando tensões residuais significativas (concentradores de tensão) na interface metal/polímero. 
$\checkmark$ Impacto único transversal central de $10 \mathrm{~J}$ previamente ao condicionamento higrotérmico essencialmente não influi na resistência residual da junta soldada, comparativamente ao resultado da simples ação ambiental (calor e umidade simultâneos);

$\checkmark$ Fadiga compressiva com a aplicação de ciclos na forma de onda senoidal não causou queda da resistência residual dos espécimes previamente virgens, ou mesmo dos impactados + condicionados;

$\checkmark$ Fadiga compressiva senoidal parece ter efeito deletério nas propriedades residuais de juntas termoplásticas soldadas previamente impactadas, porém análises estatísticas rigorosas haverão de ser aplicadas a todos os casos de forma a confirmar tendências com elevado grau de significância;

Continuando a análise, agora para os CDPs de EPX, em seguida, se tem 0 gráfico de barras plotado na Figura 4.2 (os correspondentes pontos de dados são listados na Tabela A.2 em Apêndices), ilustrando a força máxima obtida no ensaio de F4P para casa condição dos CDPs de EPX-C

Os gráficos da Figura B.2 (em Apêndices) evidenciam que os CDPs para todas as condições de ensaio exibiram comportamento não-linear na parte final da curva. Este aumento da inclinação da curva conforme se aproxima da carga última, pode ser associado à pequena distancia dos apoios da base ("span") usado para apoiarem as juntas nos ensaios de flexão sob quatro pontos conforme descrito no capítulo 3 Figura 3.6. A ruptura para todos os CDPs ocorreram de modo frágil, exceto para os CDPs do tipo virgem, onde se observou na curva pequenas quedas na carga associadas ao rompimento de fibras e/ou delaminações antes de atingir a carga máxima de ruptura total do laminado. 


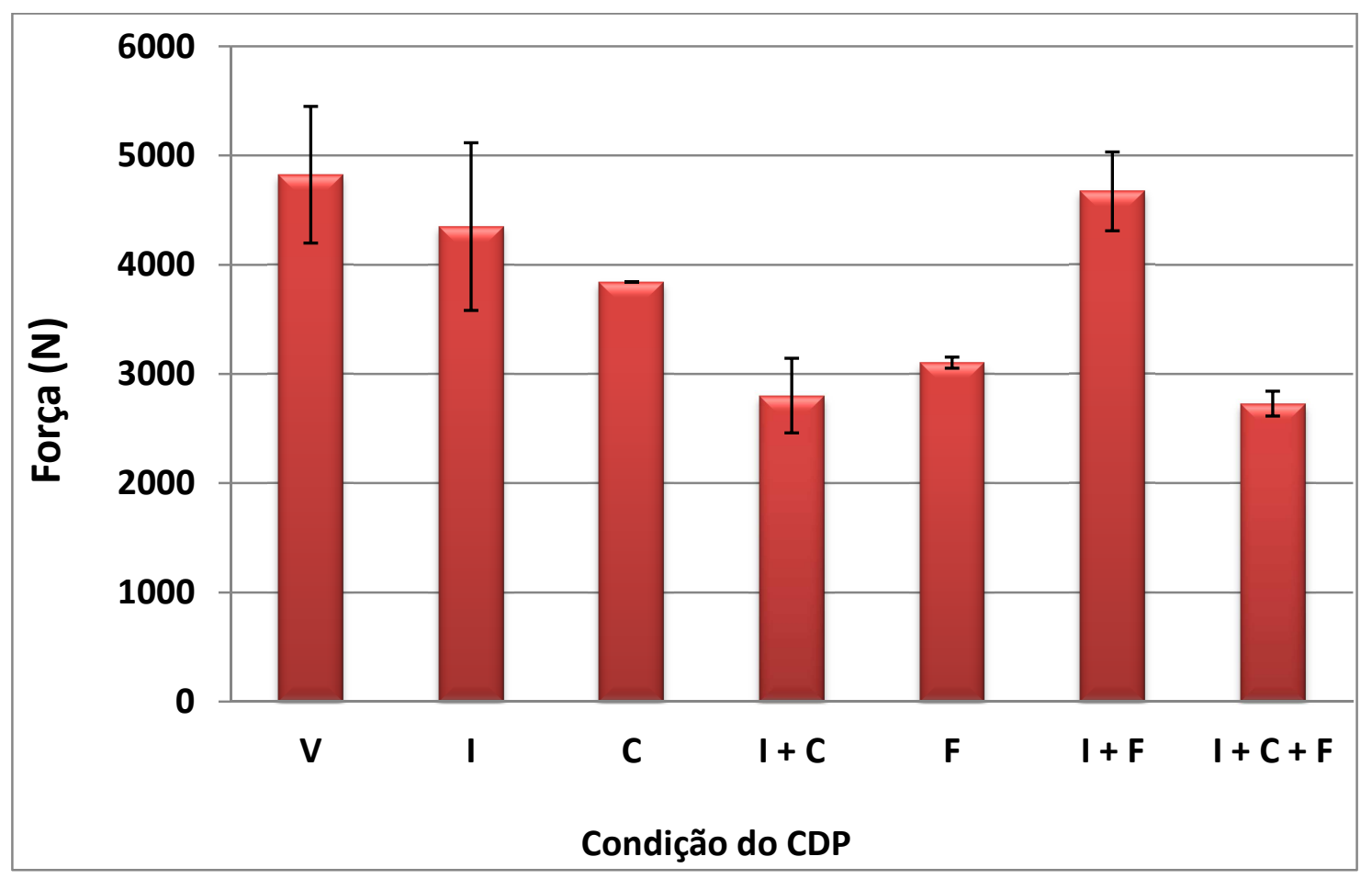

Figura 4.2 - Gráfico dos valores médios de força máxima para os CDPs de EPX-C nas condições Virgem (V), Impactado (I), Condicionado (C), Impactado + Condicionado (I+C), Fadigado $(\mathrm{F})$, Impactado + Fadigado $(\mathrm{I}+\mathrm{F})$ e Impactado + Condicionado + Fadigado $(\mathrm{I}+\mathrm{C}+\mathrm{F})$.

Com relação às juntas EPX-C, os resultados da Figura 4.2 permitem inferir que:

$\checkmark$ Considerados os valores médios obtidos para a propriedade de carga máxima, o impacto simples, o condicionamento ambiental, e a associação de impacto ao envelhecimento higrotérmico têm, nesta ordem, crescente efeito deletério na resistência mecânica residual da junta termorrígida colada. Muito provavelmente, 0 efeito deletério do envelhecimento higrotérmico se verificaria particularmente por intermédio da degradação físico-química (hidrólise) do adesivo de natureza epoxídica;

$\checkmark$ Fadiga aplicada na forma de onda senoidal causa degradação da resistência mecânica da junta colada termorrígida de praticamente mesma ordem que a aplicação de impacto de $10 \mathrm{~J}$ e subseqüente condicionamento higrotérmico, o qual já havia sido classificado como o tratamento mais pernicioso dentre os avaliados para esta junta (levando a uma perda de aproximadamente $40 \%$ da resistência com relação à condição de como-recebida);

$\checkmark$ O resultado da fadiga compressiva axial de onda senoidal aplicada posteriormente ao impacto prévio de $10 \mathrm{~J}$ indica a possibilidade de um 
aumento da resistência mecânica residual à flexão da junta. Este fenômeno já é amplamente reconhecido no meio científico, sendo denominado wear-in (SWAIN et al., 1993) e (TARPANI et al., 2006), estando associado à mitigação da força motriz para a fratura do material em decorrência da criação e da dispersão/difusão de mecanismos de tenacificação durante o carregamento cíclico a partir do dano inicial causado por impacto, incrementando assim o valor crítico de tensão (ou alternativamente, de energia) necessário para a fratura catastrófica da junta;

$\checkmark$ O mesmo efeito não é observado para o material previamente impactado e condicionado, donde se pode deduzir pela forte influência da ação ambiental (calor e umidade) no sentido de impedir a ocorrência dos fenômenos descritos no item anterior e/ou de favorecer o desenvolvimento de danos mais críticos (ex., delaminações) que impeçam a recuperação do material por efeitos de fadiga;

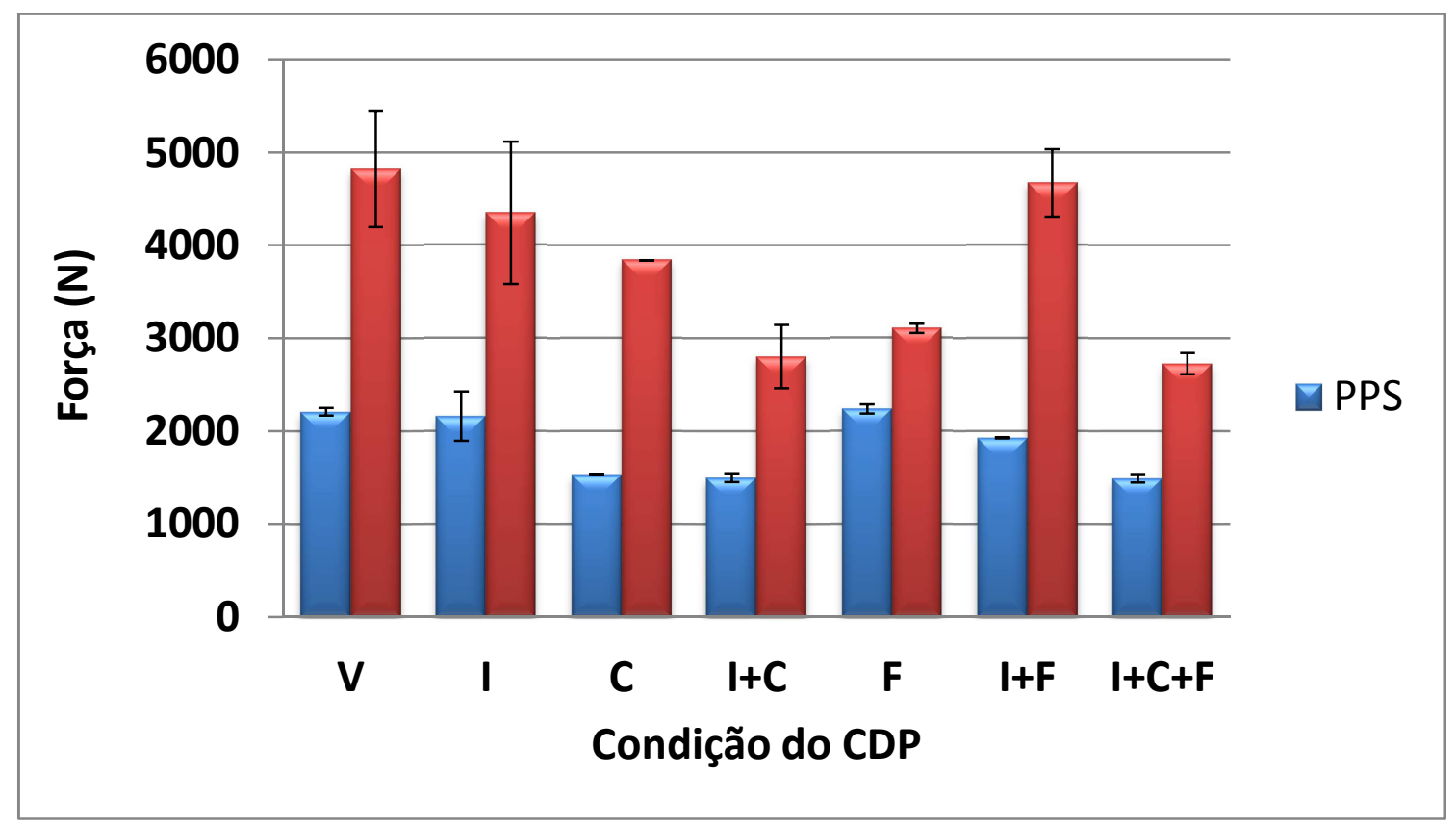

Figura 4.3 - Gráfico comparativo dos valores médios de força máxima para os CDPs de PPS-C e EPX-C para as condições de CDP conforme definidas no capítulo 3.

A Figura 4.3 compara os valores médios de força máxima obtidos no ensaio de F4P para as juntas de PPS-C e EPX-C. Nota-se que a junta de EPX-C apresentou os maiores valores de carga para todas as condições dos CDPs ensaiados e para 
alguns casos, a carga suportada pela junta EPX-C foi o dobro da carga da junta de PPS-C, como por exemplo, na condição do CDP virgem.

\subsection{Rigidez em F4P}

A Figura 4.4 exibe gráficos da rigidez das juntas compósitas determinada durante ensaios de resistência residual por F4P, após a aplicação de uma grande variedade de condicionamentos às mesmas.

Resumidamente, a análise dos dados relativos à rigidez das juntas PPS-C soldadas e EPX-C adesivadas permite verificar que, de modo geral, as juntas termorrígidas coladas EPX-C se mostram mais susceptíveis aos condicionamentos aplicados para degradação de seu desempenho mecânico em F4P. Além disso, em face da relativamente pequena diferença entre as rigidezes devido às ações degradatórias dos tratamentos propositadamente aplicados às juntas, assim como em decorrência dos espalhamentos de dados (desvio-padrão) significativos em alguns casos, será necessária a aplicação de análises e critérios estatísticos de confiabilidade aos dados experimentalmente obtidos (três CDPs por condição avaliada das juntas), de modo a se comprovar que os efeitos negativos inferidos quanto à rigidez dos materiais possui significância estatística.

A Figura 4.5 resume os valores médios de rigidez obtidos no ensaio de F4P para as juntas de PPS-C e EPX-C. Nota-se que ambos os tipos de juntas apresentaram valores muito próximos, tanto para os CDPs como manufaturados assim como para aqueles submetidos a condições degradatórias dos tratamentos propositadamente aplicados às juntas. 


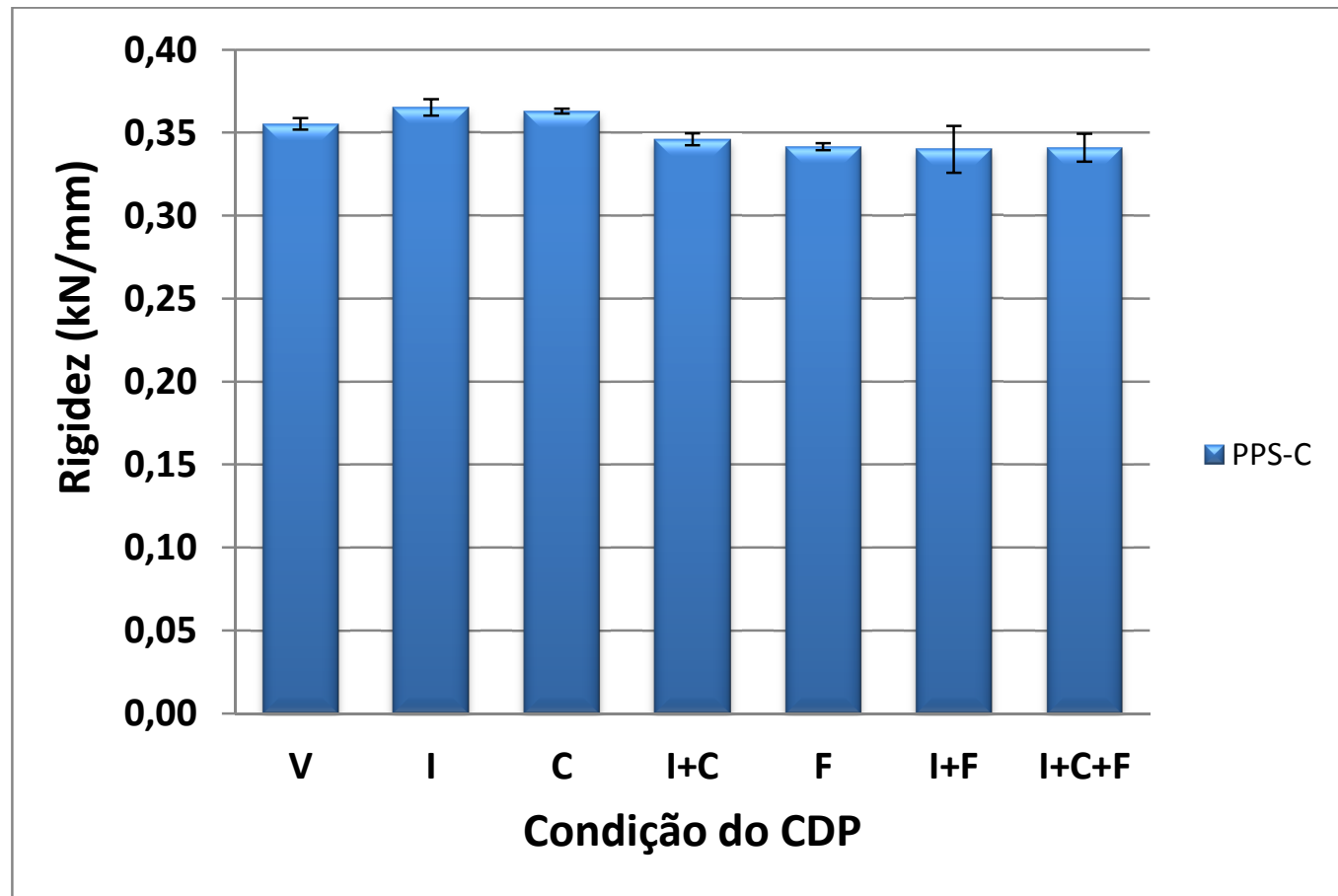

(a)

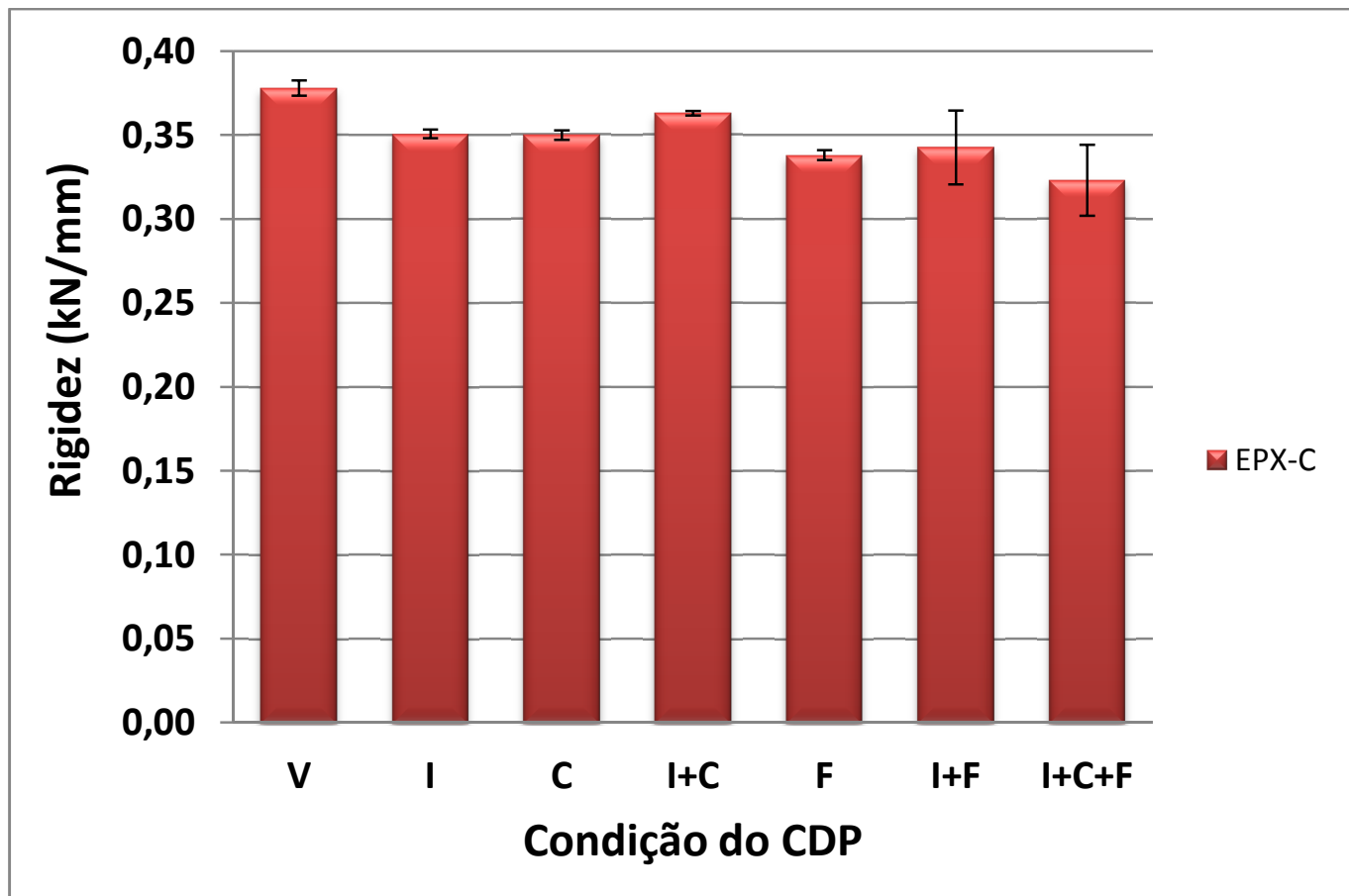

(b)

Figura 4.4 - Gráficos de rigidez das juntas compósitas durante ensaio de F4P após diversos condicionamentos aplicados as mesmas (Virgem, Impactada, Condicionada, Impactada + Condicionada, Fadigada, Impactada + Fadigada e Impactada + Condicionada + Fadigada conforme definidas no capítulo 3), (a) Juntas PPS-C, e (b) Juntas EPX-C. 


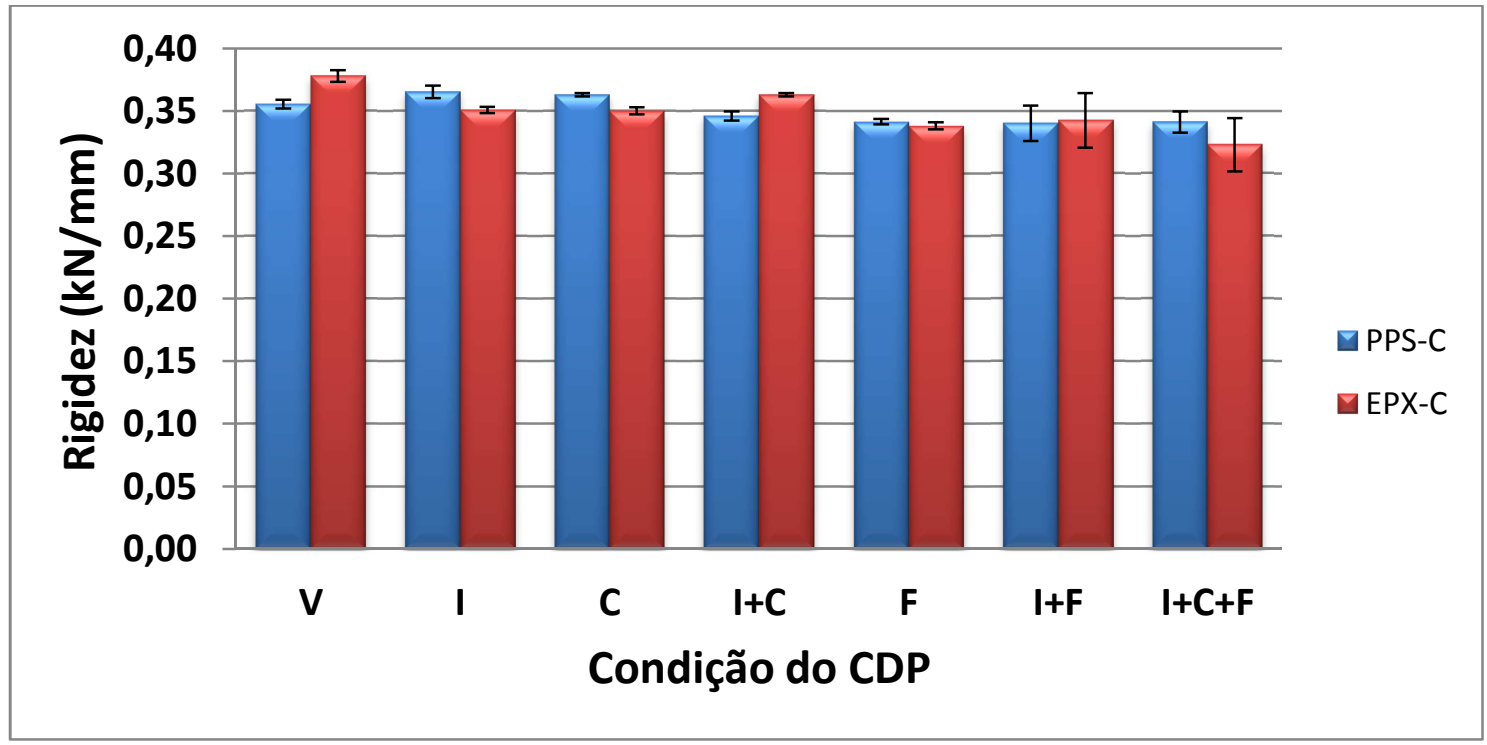

Figura 4.5 - Gráfico comparativo dos valores de rigidez para os CDPs de PPS-C e EPX-C para as condições de CDP conforme definidas no capítulo 3.

\subsection{Modos de falha}

A análise dos modos de falha foi subdividida em três partes começando pela análise de falha em escala macro, ou seja, determinar o modo de falha por análise visual da superfície da área de junção da junta, seguida da análise meso via imagens de estereoscópio visando observar a interação dos elementos de união com os aderentes, e como última etapa da análise de falha das juntas, utilizou-se da microscopia óptica e eletrônica de varredura (MEV) para analisar características como interação fibra-matriz, resina-malha de aço, assim como outros aspectos do processo de união das juntas somente observados em escala microscópica.

\subsubsection{Análise macroscópica da falha}

Após os ensaios quase-estático de flexão sob quatro pontos, todos os CDPs pós-fratura tiveram a superfície de soldagem e colagem fotografadas para análise do 
tipo de falha ocorrida (ver Tabelas A.3 e A.4 em Apêndices). Novamente, tem-se a análise separada para o PPS-C e EPX-C.

Para as juntas soldadas, os modos de falha podem ser classificados em duas categorias, a interfacial e a intralaminar. Tem-se uma terceira que é a fratura do laminado (fora da área de soldagem), mas este tipo de falha não foi observado para os CDPs testados.

A Figura 4.6a e Figura 4.6b mostram as superfícies de fratura da junta PPS-C nas condições de, respectivamente, virgem (V) e impactada (I) sob 10 Joules. Os valores de resistência mecânica em F4P da junta impactada foram muito próximos aos da junta como-manufaturada (virgem). Observa-se a presença de uma impressão na interface entre os dois laminados (indicada por circulo azul tracejado), indicando que o impacto criou danos, porém não severos o suficiente para degradar as propriedades mecânicas residuais da junta termoplástica soldada.
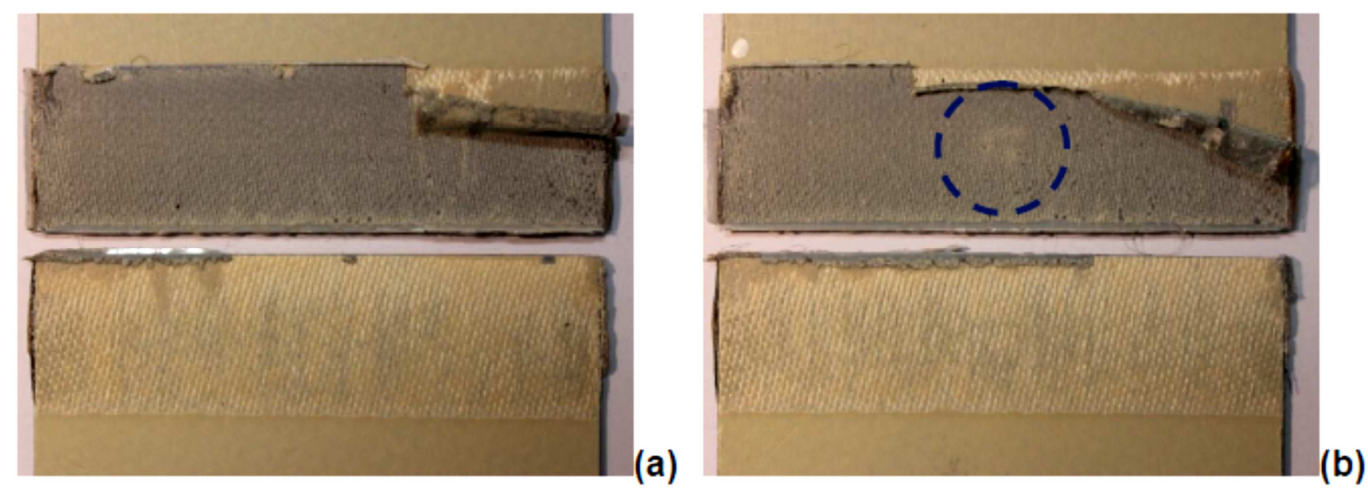

Figura 4.6 - Aspectos da interface de fratura entre laminados gerada por ensaio F4P de juntas PPS-C nas condições de virgem (a), e impactada a 10 Joules (b).

A Figura 4.7 mostra as superfícies de fratura da junta PPS-C nas condições de, respectivamente, $(\mathrm{C})$ e $(\mathrm{I}+\mathrm{C}+\mathrm{F})$, conforme definidas no capítulo 3 . Os valores de resistência mecânica em F4P da junta simplesmente condicionada foram bastante similares aos da junta impactada + condicionada + fadigada, confirmando o fato de que a junta PPS-C se mostrou particularmente sensível a efeitos higrotérmicos, se comparada à EPX-C. Observa-se que há um descolamento interfacial bastante plano, muito provavelmente facilitado pelo condicionamento ao qual as duas juntas foram submetidas visando a degradação das suas propriedades mecânicas. 

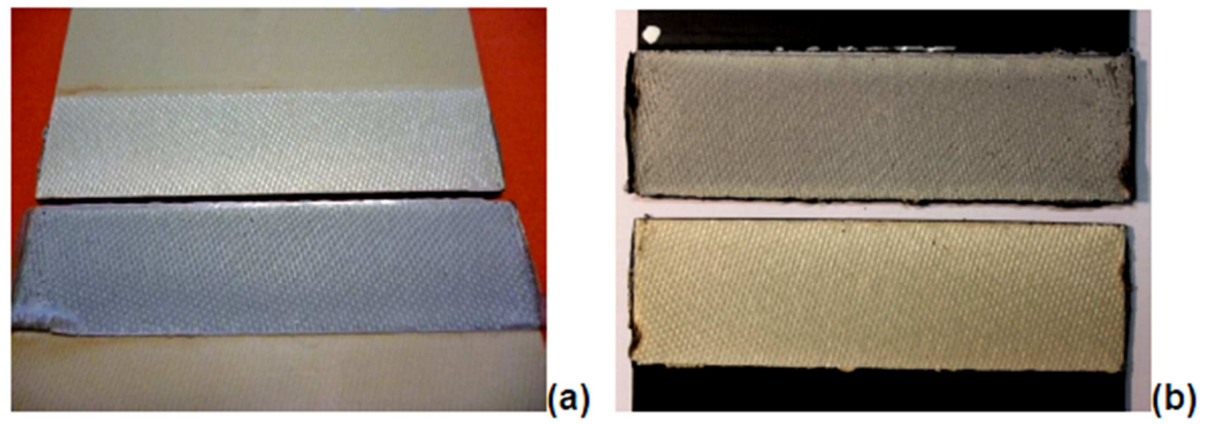

Figura 4.7 - Aspectos da interface de fratura entre laminados gerada por ensaio F4P de juntas PPS-C nas condições de (a) Condicionada e (b) Impactada + Condicionada + Fadigada.

A Figura 4.8 mostra as superfícies de fratura da junta PPS-C nas condições de, respectivamente, $\mathrm{I}+\mathrm{C}, \mathrm{F}$, e I+F, conforme definidas no capítulo 3 .

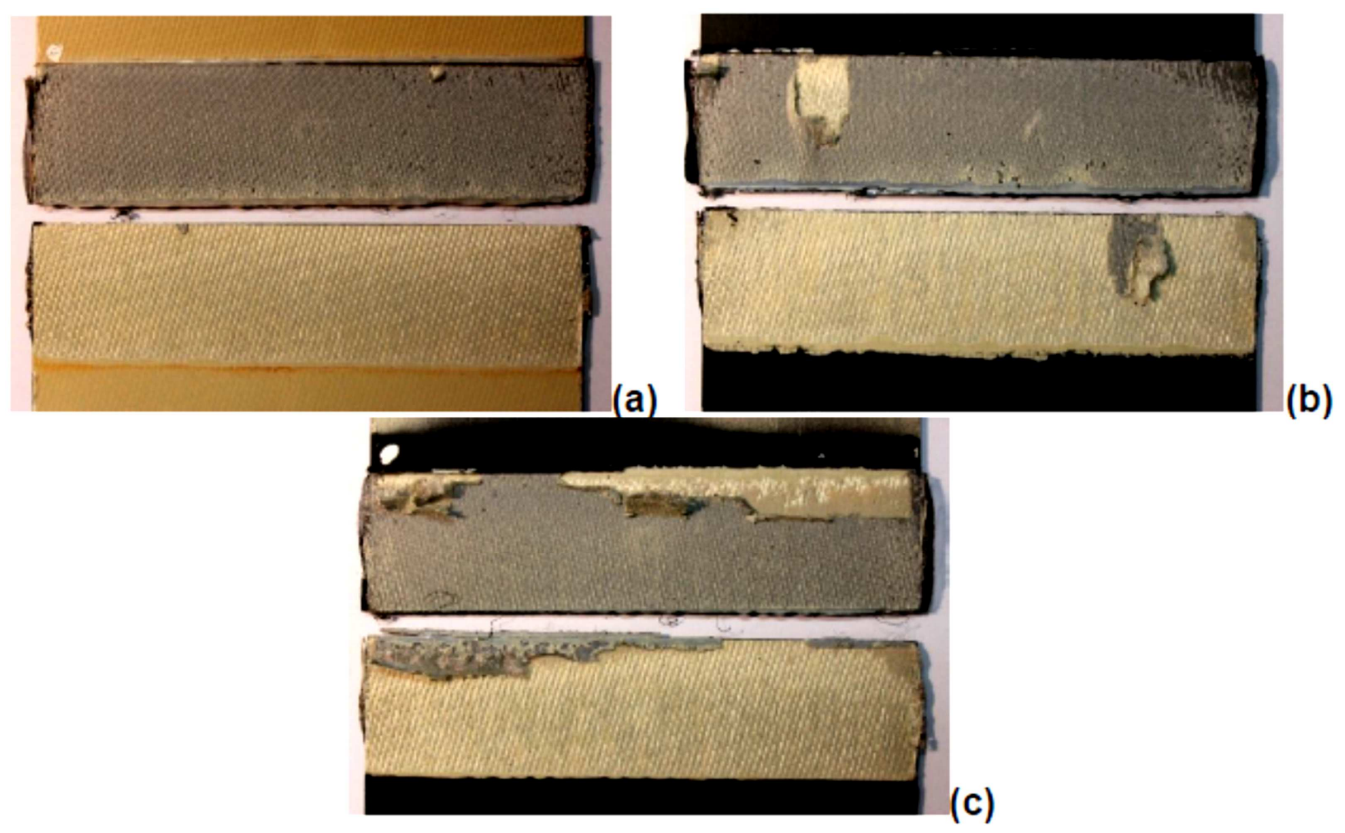

Figura 4.8 - Aspectos da interface de fratura entre laminados gerada por ensaio F4P de juntas PPS-C nas condições de impactada + condicionada (a), apenas fadigada (b), e impactada + fadigada.

Considerando-se as definições acima e a análise da superfície de fratura dos corpos de prova fraturados em ensaio de resistência residual em F4P, pode-se observar também que:

$\checkmark$ modo de falha predominante nos espécimes soldados foi à fratura intralaminar envolvendo dano do elemento gerador de calor, mas sem danos 
no laminado. O dano na malha inicia-se nas bordas e caminha em direção ao centro da área soldada;

$\checkmark$ A exceção a esta regra foram os corpos de prova submetidos ao condicionamento higrotérmico (temperatura e umidade aplicados concomitantemente), que apresentaram modo de falha essencialmente interfacial, caracterizado por baixos valores de resistência sob F4P;

$\checkmark$ A aplicação de ciclos de fadiga compressiva aparentemente não causou alterações significativas no modo de falha dos CDPS em relação aqueles em condições semelhantes, porém não fadigados.

Para as juntas de EPX-C, a Figura 4.9 mostra as superfícies de fratura da junta EPX-C nas condições de, respectivamente, virgem (V) e impactada (I) sob 10 Joules. Os valores de resistência mecânica em F4P da junta impactada foram substancialmente inferiores aos da junta virgem, indicando forte dependência quanto aos danos impingidos e criados por impacto pontual transversal.
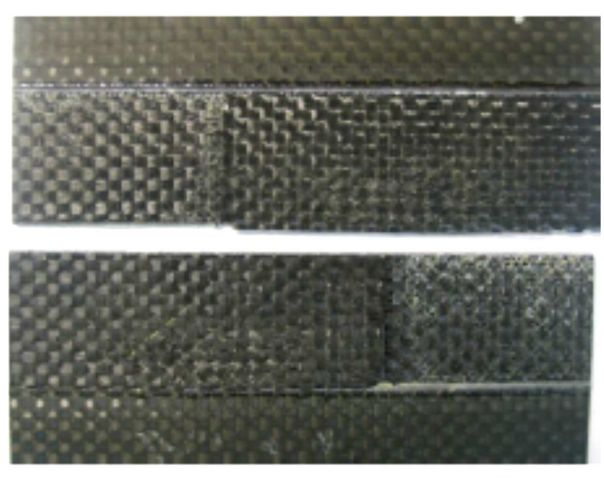

(a)

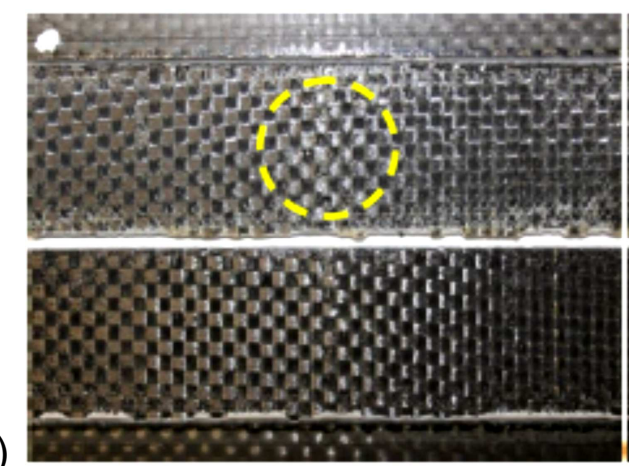

(b)

Figura 4.9 - Aspectos da interface de fratura entre laminados gerada por carregamento em F4P de juntas EPX-C nas condições de (a) virgem e (b) impactada.

Entretanto, diferentemente da junta PPS-C, é difícil observar a presença de uma impressão correspondente ao choque mecânico na interface entre os dois laminados (região indicada por circulo amarelo tracejado), confirmando que a junta termoplástica possui uma ductilidade superior à termorrígida, o que possibilita a inferência de danos estruturais por impacto, mesmo que estes não causem perdas significativas de resistência mecânica. 
A Figura 4.10 mostra as superfícies de fratura da junta EPX-C nas condições de, respectivamente, simplesmente condicionada higrotermicamente $(C)$ e impactada + condicionada + fadigada $(\mathrm{I}+\mathrm{C}+\mathrm{F})$. Os valores de resistência mecânica em F4P da junta impactada + condicionada + fadigada foram bastante inferiores aos da junta simplesmente condicionada, confirmando o fato de que a junta EPX-C se mostrou particularmente sensível a efeitos de impacto pontual mecânico transversal, se comparada à PPS-C.
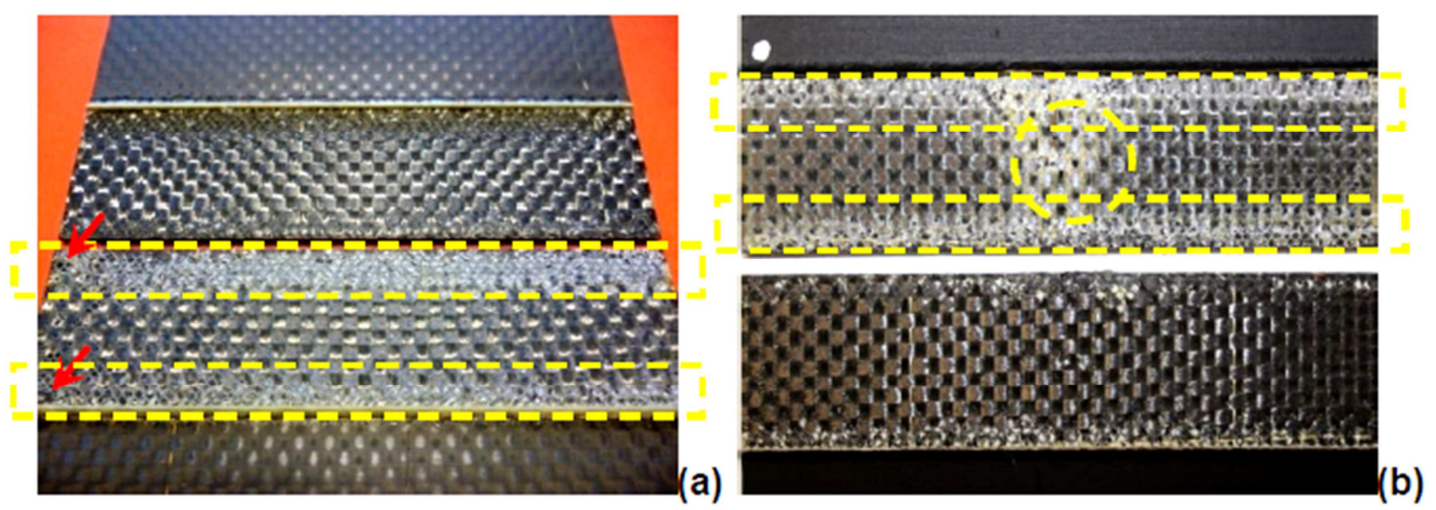

Figura 4.10 - Aspectos da interface de fratura entre laminados após F4P de juntas EPX-C nas condições de (a) Condicionada e (b) Impactada + Condicionada + Fadigada. A seta vermelha aponta alguns danos que parecem ser típicos do condicionamento higrotérmico destas juntas.

Observam-se aspectos de fratura diferenciada nas bordas da junta sobreposta decorrentes do condicionamento, sendo também interessante observar o aspecto da fratura tipo colméia desenvolvida numa das arestas da área de sobreposição dos laminados na junta, o que é indicado por uma seta vermelha Na Figura 4.10a, as mesmas nuances são reveladas na Figura $4.10 \mathrm{~b}$, porém é nítida também a impressão de impacto e danos provavelmente desenvolvidos em fadiga tanto na região anteriormente fragilizada por condicionamento (bordas do espécime indicadas por retângulos tracejados amarelos, submetida a esforços de tração - peel stress, durante o fadigamento, como decorrência da indução local de flambagem (GREENHALGH; HILEY, 2008) e (GREENHALGH, 2009) como por impacto (centro do corpo de prova no interior do círculo tracejado amarelo, que experimentou esforços e danos mais significativos de cisalhamento - shear stress). Pode-se, assim inferir que as bordas estejam mais susceptíveis ao condicionamento associado à 
fadiga, enquanto que, o centro do espécime, ao condicionamento vinculado ao impacto.

A Figura 4.11 mostra as superfícies de fratura da junta EPX-C nas condições de, respectivamente, impactada + condicionada (em que se observam efeitos da aplicação de temperatura e umidade particularmente no ponto de impacto transversal), simplesmente fadigada, e impactada + fadigada. Nestes dois últimos casos as morfologias de fratura se mostram bastante distintas, demonstrando claramente que a fadiga pós-impacto atua no sentido de difundir danos e mitigar o efeito de concentração de tensões provocada originalmente pelo impacto pontual, o que resulta num aumento da resistência residual em F4P ("wear-in process").

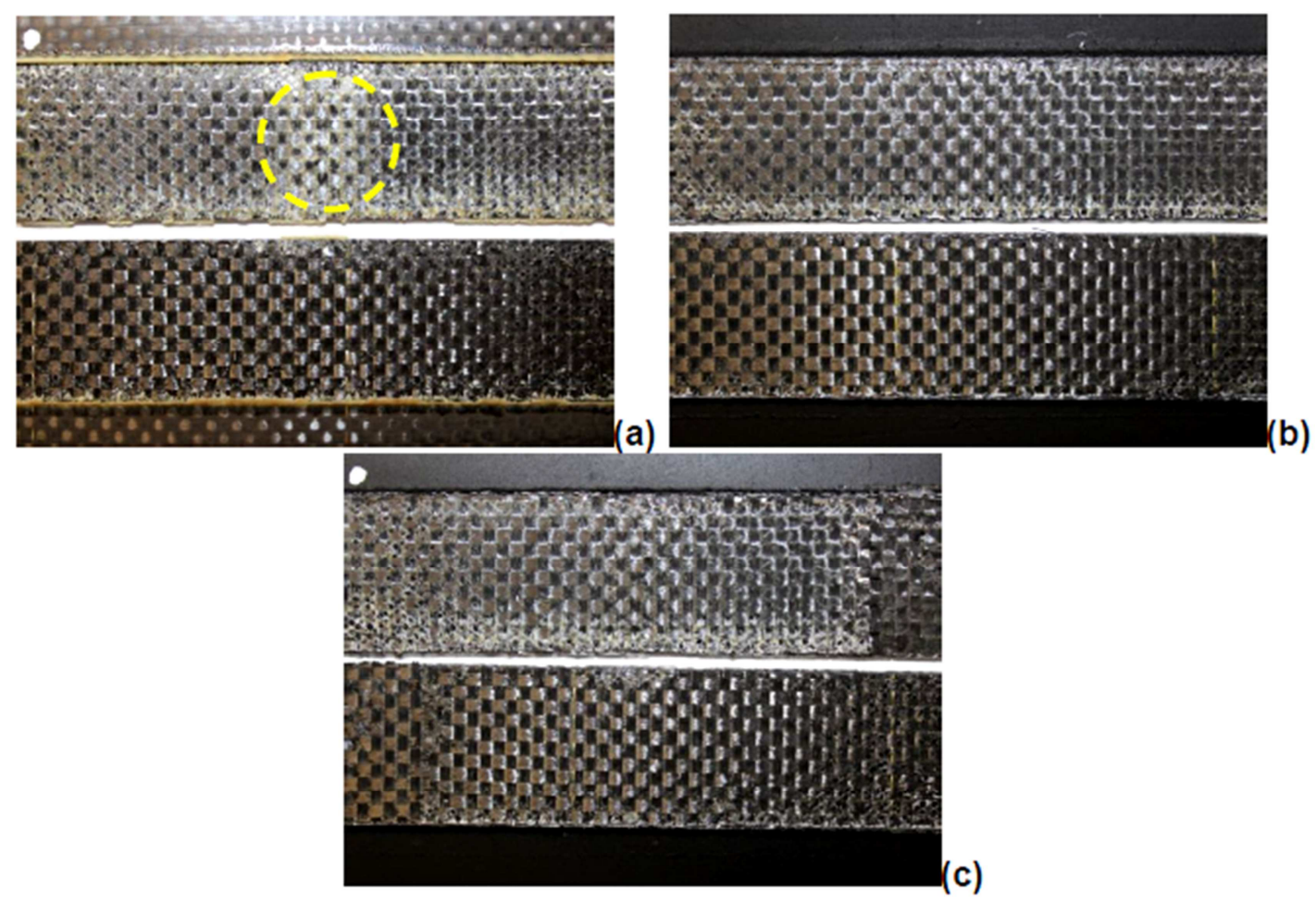

Figura 4.11 - Aspectos da interface de fratura entre laminados gerada por carregamento lento em F4P de juntas EPX-C nas condições de impactada + condicionada (a), apenas fadigada (b), e impactada + fadigada.

Com base nas análises macroscópicas das superfícies das juntas EPX-C podese também estabelecer as seguintes conclusões:

$\checkmark$ Os CDPs impactados + condicionados_exibiram fratura interfacial, e em alguns casos apresentam vazios/bolhas na área de colagem; 
$\checkmark$ Os CDPs simplesmente fadigados apresentaram fratura interfacial, com um dos CDPs exibindo grande quantidade de vazios/bolhas na área de colagem;

$\checkmark$ Os CDPs condicionados apresentaram fratura interfacial e exibiram vazios/bolhas.

$\checkmark$ Os CDPs impactados + condicionados + fadigados apresentaram fratura interfacial, sendo a presença de vazios/bolhas observada raramente.

$\checkmark$ Os CDPs virgens apresentaram em sua maioria um misto de fratura interfacial + interlaminar e uma minoria exibiu apenas fratura interlaminar.

$\checkmark$ Os CDPs impactados exibiram em sua minoria fratura interfacial + interlaminar e a maioria apresentou fratura interfacial. A fratura revelou a presença de vazios/bolhas ao longo da área de colagem.

$\checkmark$ Os CDPs impactados + fadigados apresentaram fratura interlaminar ou mista interfacial + intralaminar. Vazios/bolhas na área de colagem foram extensivamente observados nas amostras

$\checkmark$ Pode-se também afirmar que 0 condicionamento teve efeito negativo no desempenho mecânico da junta termorrígida, uma vez que todas as amostras sob esta condição apresentaram fratura interfacial;

$\checkmark$ Para os corpos de prova submetidos ao carregamento em fadiga, o efeito de carregamento cíclico é mais notável nas amostras virgens e praticamente sem efeitos consideráveis nas demais amostras;

$\checkmark$ A presença de vazios/bolhas na área de colagem afetou o desempenho mecânico da junta para uma mesma condição de ensaio.

$\checkmark$ Parte do grande desvio padrão apresentado nos ensaios de resistência residual sob F4P pode ser atribuído à presença de vazios/bolhas nas amostras sob uma mesma condição.

Resumindo a questão da análise macroscópica de falha para as juntas PPS-C e EPX-C, constata-se que para a junta de PPS-C, aquelas submetidas ao condicionamento higrotérmico, o modo de falha observado foi o interfacial provocando menores valores de resistência, enquanto que para as demais condições o modo de falha foi o intralaminar. Para os CDPs de EPX simplesmente fadigados, condicionados, impactados e condicionados apresentaram modo de falha 
interfacial como predominante. Ainda para o EPX, pode-se atribuir a influência da presença de vazios/bolhas na colagem, como fator que contribuiu negativamente para a variação dos modos de falhas apresentados pelos CDPs para uma mesma condição.

\subsubsection{Análise mesoscópica da falha (estereoscópio)}

Como o tipo de CDP empregado neste estudo apresenta área de soldagem e colagem relativamente grandes $(100 \mathrm{~mm} \times 25 \mathrm{~mm}$ ), decidiu-se representar as bordas e o centro por números (Figura 4.12) a fim de que fosse possível diferenciar as características de cada uma dessas regiões pós-ensaio de flexão sob quatro pontos. $\mathrm{Na}$ análise estereoscópica foi possível observar em maior nível de detalhe as superfícies de interface previamente avaliadas visualmente.

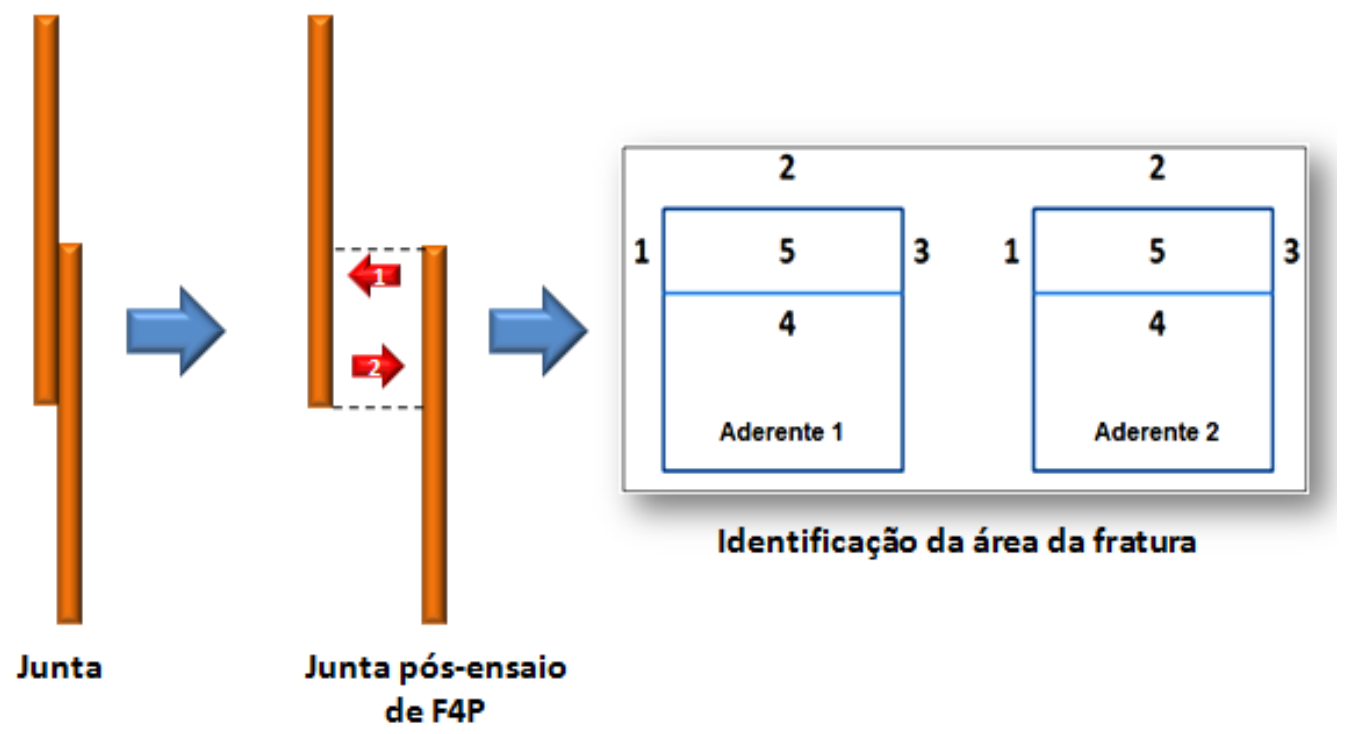

Figura 4.12 - Representação da divisão das áreas de soldagem e colagem para análise de suas características.

Os números 1 e 3 representam as bordas livres menores (entrada e saída da corrente aplicada durante o processo de soldagem para o PPS-C). Os números 2 e 4 representam as bordas livres maiores dos CDPs e o número 5 representa o centro 
da amostra. Esta divisão é vista na Figura 4.12 e utilizou-se esta nomenclatura para os CDPs soldados (PPS-C) e colados (EPX-C).

Para representação geral das características de processo de soldagem do PPSC e danos pós-ensaio encontrados na superfície de fratura dos CDPs soldados, das seis amostras submetidas à estereoscopia (veja Tabela A.3 em Apêndices) separouse três delas para ilustrar essa seção, que foram o CDP $23(\mathrm{~V})$, CDP $42(\mathrm{I}+\mathrm{C})$ e 0 CDP $5(\mathrm{I}+\mathrm{F})$.

Para o CDP 23 (V) a Figura 4.13 representa as duas faces pós-ensaio de F4P e tomando como base a divisão por setores mostrada na Figura 4.12, observa-se na Figura 4.13a que as bordas 1 e 3 apresentam maior quantidade de vazios onde a malha metálica ficou exposta sem presença de resina justamente nas bordas referentes a entrada e saída de corrente. Nestas áreas a ausência de resina pode ser associada a maior temperatura alcançada fazendo com que a resina flua para fora da área de soldagem ("squeeze out') devido a pressão aplicada durante o processo de soldagem

Nas bordas mais extensas, denominadas aqui como 2 e 4, nota-se a presença de danos causados a malha metálica (fratura intralaminar) assim como presença de vazios. Outro aspecto importante é a existência de áreas onde não houve consolidação do filme com a resina do laminado.

Para a área 5, representada pelas duas fotos centrais, observa-se maior regularidade na superfície de soldagem, embora ainda seja possível notar a presença de vazios evidenciados pela malha metálica exposta.

A Figura 4.13b apresenta à face oposta a face mostrada na Figura 4.13a. Ainda utilizando-se da notação da Figura 4.12, para as borda 1 e 3 observa-se a interface bastante irregular causada devido ao maior gradiente de temperatura nestas bordas, como mencionado anteriormente.

As bordas 2 e 4 apresentam as fibras de vidro expostas da camada externa e áreas com marcas na resina que envolvia a malha metálica. 


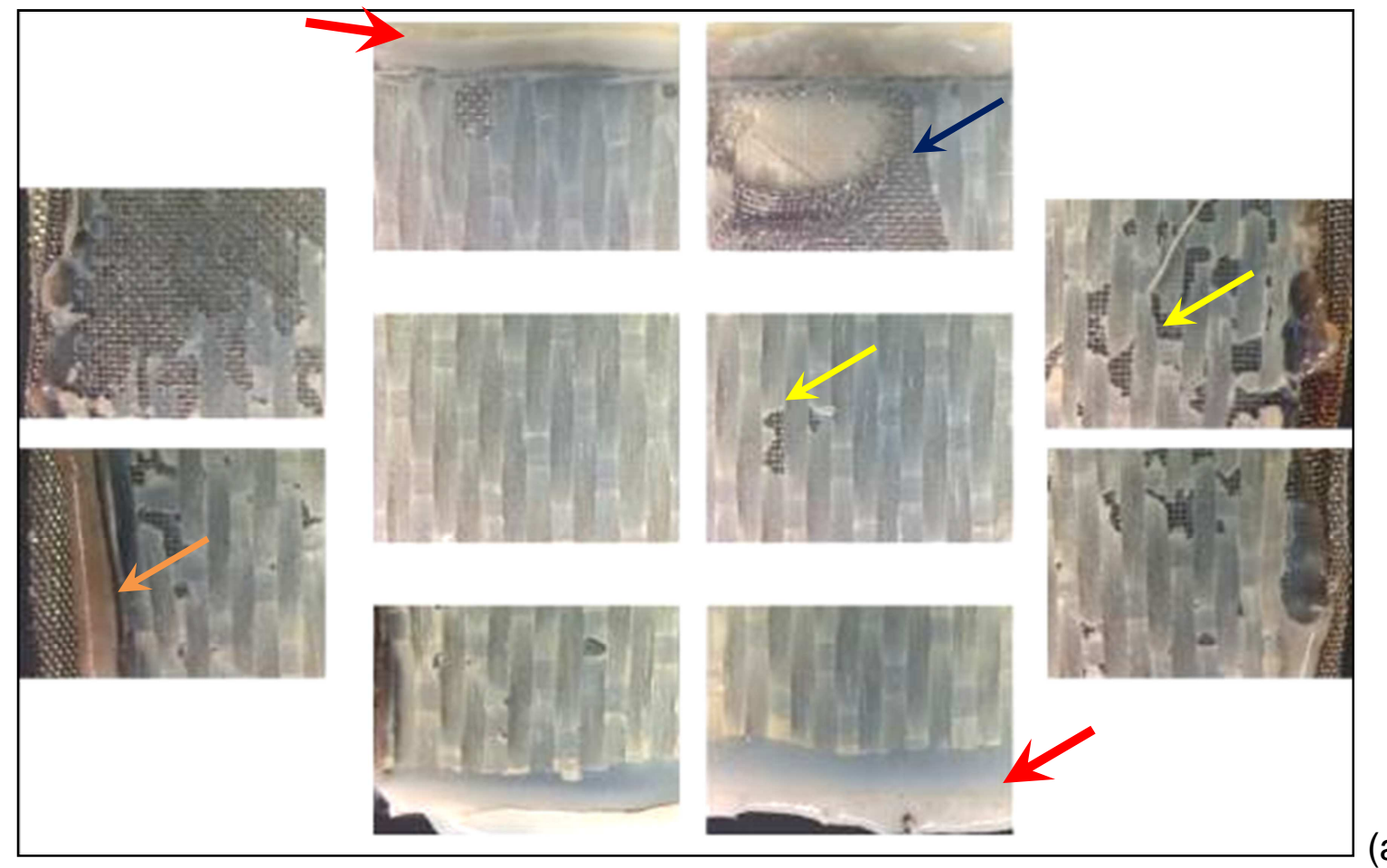

(a)

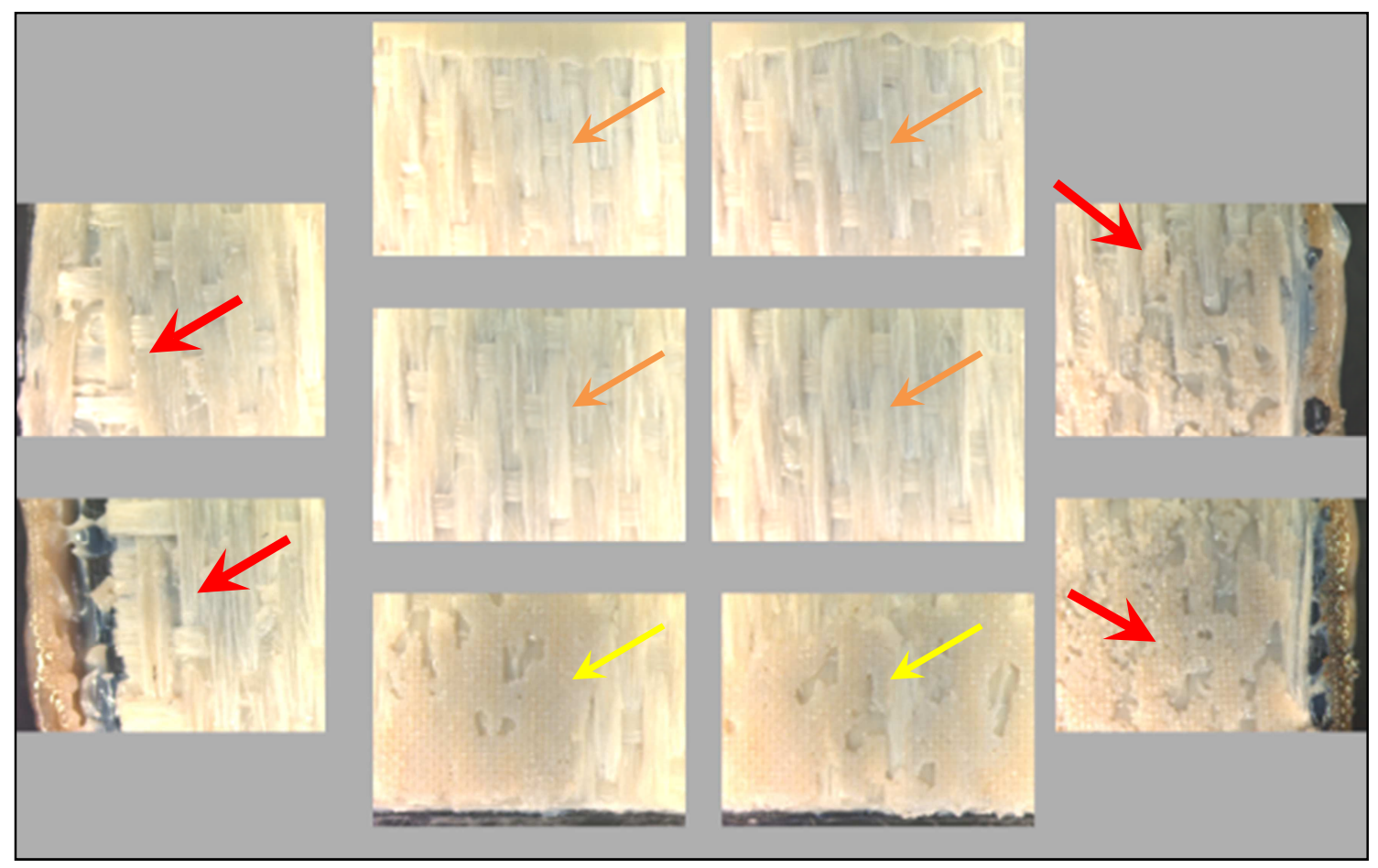

(b)

Figura 4.13 - Representação parcial da área pós-ensaio do CDP 23 (V) onde (a) se tem danos na malha metálica (seta azul), vazios (setas amarelas), resina não consolidada (setas vermelhas) e resina degradada devido à alta temperatura atingida na borda (seta laranja) (b) a face oposta com a interface de união irregular (seta vermelha), resina que envolvia a malha metálica (setas amarelas) e camada de fibra de vidro exposta (setas laranjas). 
A área 5 que representa o centro, notam-se as fibras de vidros expostas e superfície regular, evidenciando melhor qualidade da soldagem na região central, embora também demonstre a fraca interação entre a resina PPS e a camada de fibra de vidro.

Para os outros dois CDPs $42(\mathrm{I}+\mathrm{C})$ e $5(\mathrm{I}+\mathrm{F})$ são mostradas fotos com maiores detalhes da características encontradas na interface de soldagem ao invés da vista geral mostrada para o CDP $23(\mathrm{~V})$.

Na Figura 4.14 referente ao CDP $42(\mathrm{I}+\mathrm{C})$ representando as bordas 1 e 3, vê-se em detalhes a presença de vazios e uma parte remanescente da malha metálica usada para aplicação de corrente elétrica. A Figura 4.15 referente às bordas 2 e 4 mostra uma área localizada na extremidade da borda onde não houve consolidação do filme PPS com o laminado PPS-C da camada externa de fibra de vidro.

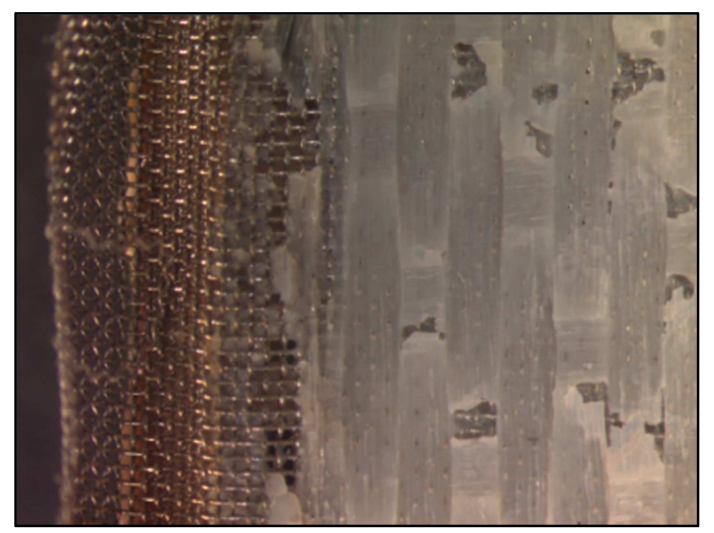

Figura 4.14 - Vista da superfície de fratura para o CDP $42(\mathrm{I}+\mathrm{C})$ referente às bordas 1 e 3.

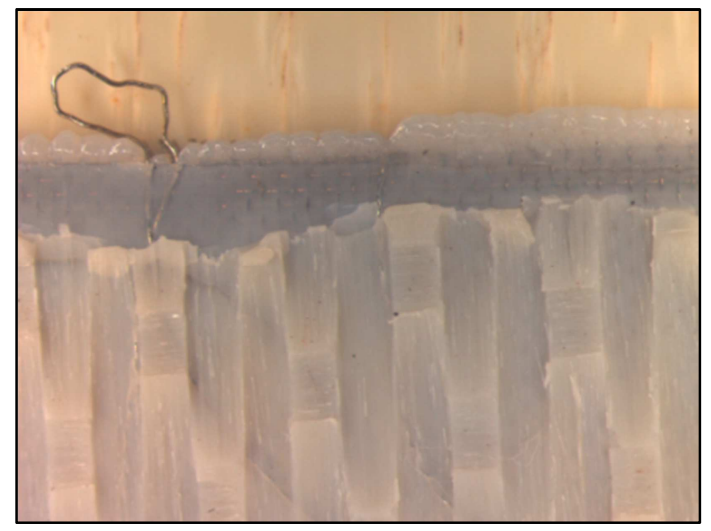

Figura 4.15 - Vista da superfície de fratura para o CDP $42(I+C)$ referente às bordas 2 e 4. 
$\mathrm{Na}$ Figura 4.16 tem-se a vista referente ao centro 5. Vê-se uma superfície uniforme e sem a presença de vazios. Na Figura 4.17 tem-se a face oposta a Figura 4.16 e nota-se que as marcas vistas no PPS seguem a forma do tecido de fibra de vidro da camada externa mostrado na Figura 4.17.

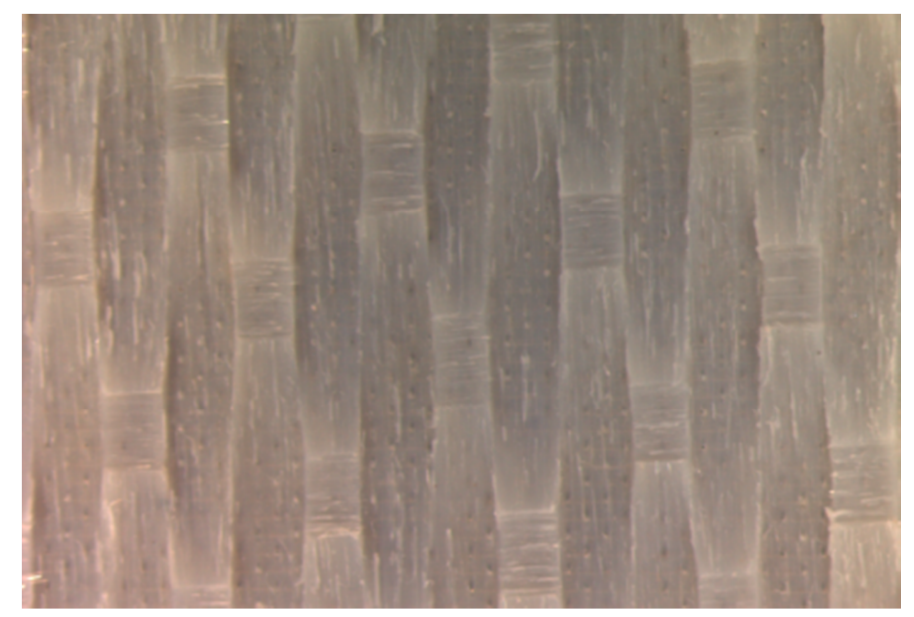

Figura 4.16 - Vista da superfície de fratura para o CDP $42(I+C)$ referente ao centro 5.

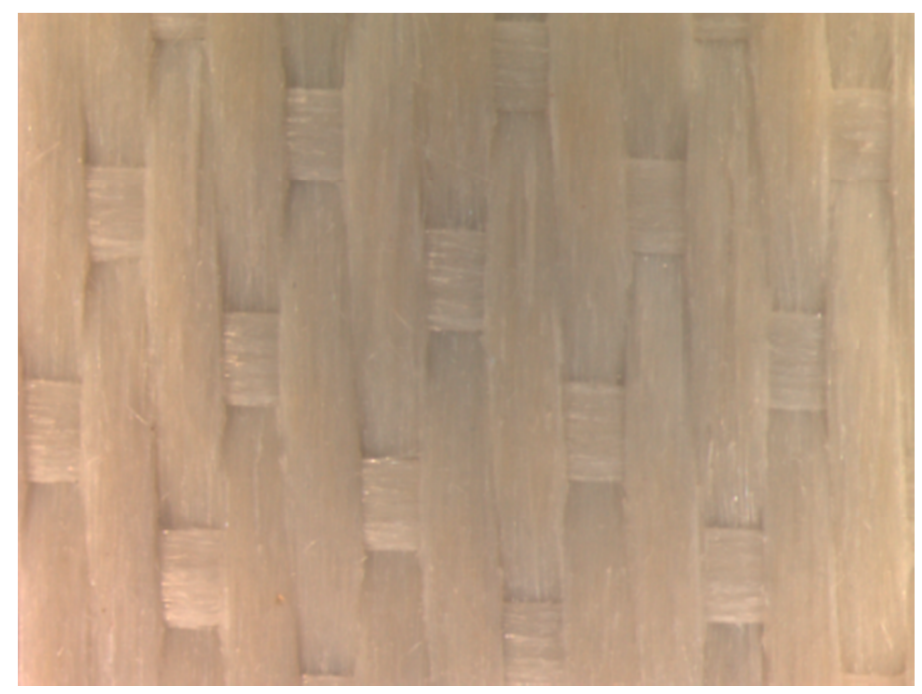

Figura 4.17 - Vista da superfície de fratura para o CDP $42(\mathrm{I}+\mathrm{C})$ referente ao centro 5 (face oposta).

Para o CDP $5(\mathrm{I}+\mathrm{F})$ Figura 4.18 escolheu-se apenas a vista representada na Figura 4.12 referente as bordas 1 e 3 . Nesta imagem é possível observar a presença de vazios, marcas da malha metálica no PPS-C além da malha metálica rompida. 


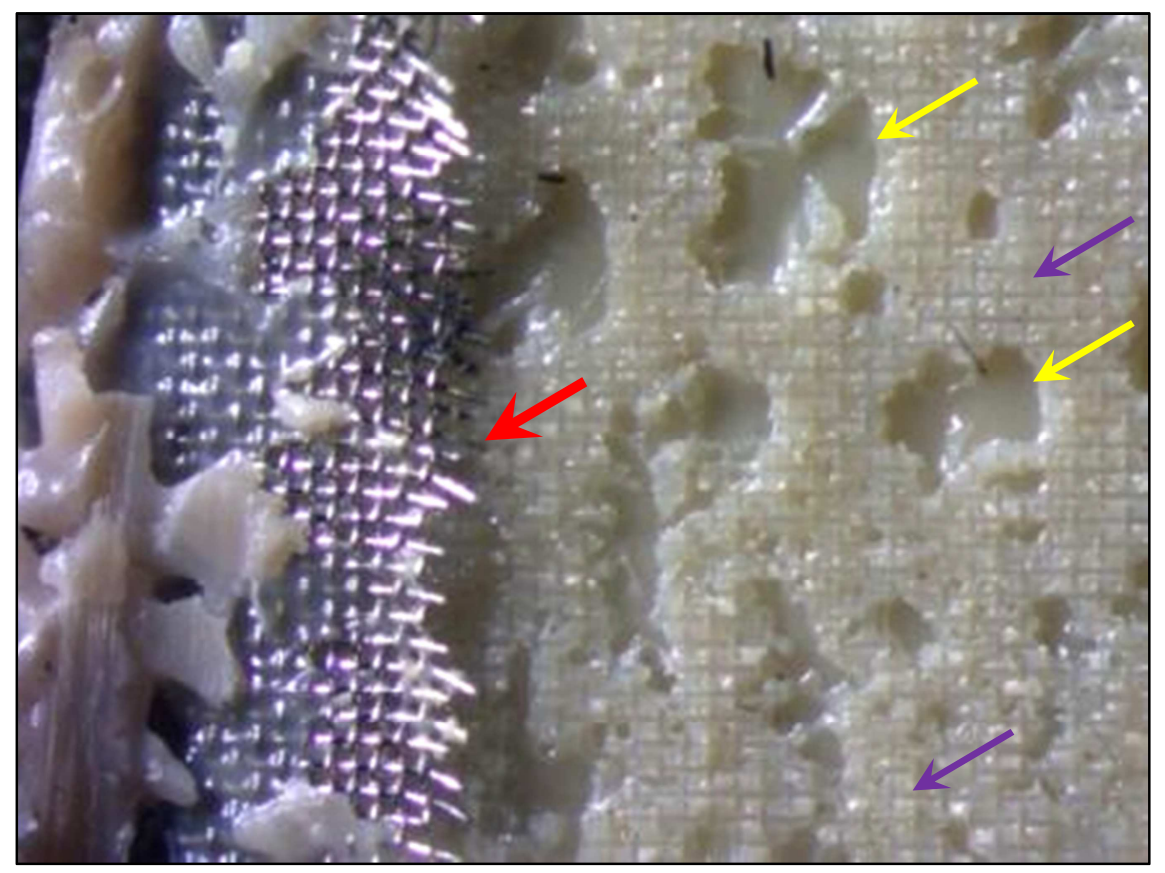

Figura 4.18 - Vista da superfície de fratura para o CDP $5(\mathrm{I}+\mathrm{F})$ referente as bordas 1 e 3. Notam-se vazios (setas amarelas), danos na malha metálica (seta vermelha) e marcas da malha metálica na resina (setas roxas).

Para a representação geral das características do processo de colagem do EPX$\mathrm{C}$ e danos pós-ensaio encontrados na superfície de fratura dos CDPs colados, separou-se dois deles (das seis amostras obtidas conforme Tabela A.4 em Apêndices) para análise e ilustração dos resultados obtidos. São eles o CDP 1115 (V) e o CDP $4(I+C)$.

Para o CDP 1115 (V) a Figura 4.19 representa as duas faces pós-ensaio e tomando como base a divisão por setores mostrada na Figura 4.12, observa-se na Figura 4.19a que na borda 1 visualiza-se o filme adesivo assim como vazios, enquanto que na borda 3 visualiza-se as fibras expostas. Isso se deve ao fato que este CDP apresentou falha interfacial + falha interlaminar.

Nas bordas mais extensas denominadas aqui 2 e 4, assim como para a área 5 central, nota-se aspectos semelhantes aos visualizados nas bordas 1 e 3 , exceto pelo fato de evidenciar o excesso de resina acumulado na borda devido a pressão aplicada durante o processo de colagem. 


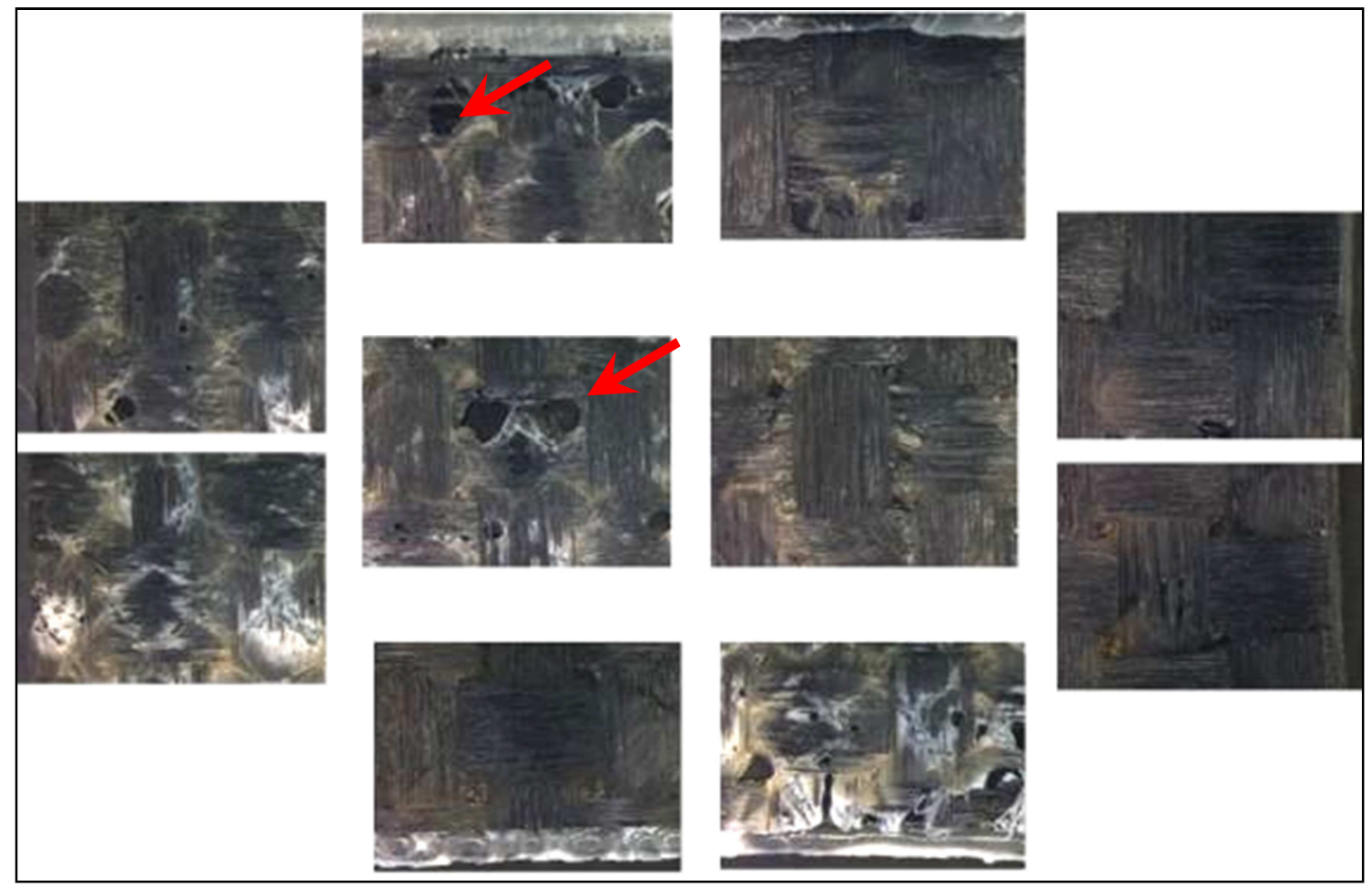

(a)

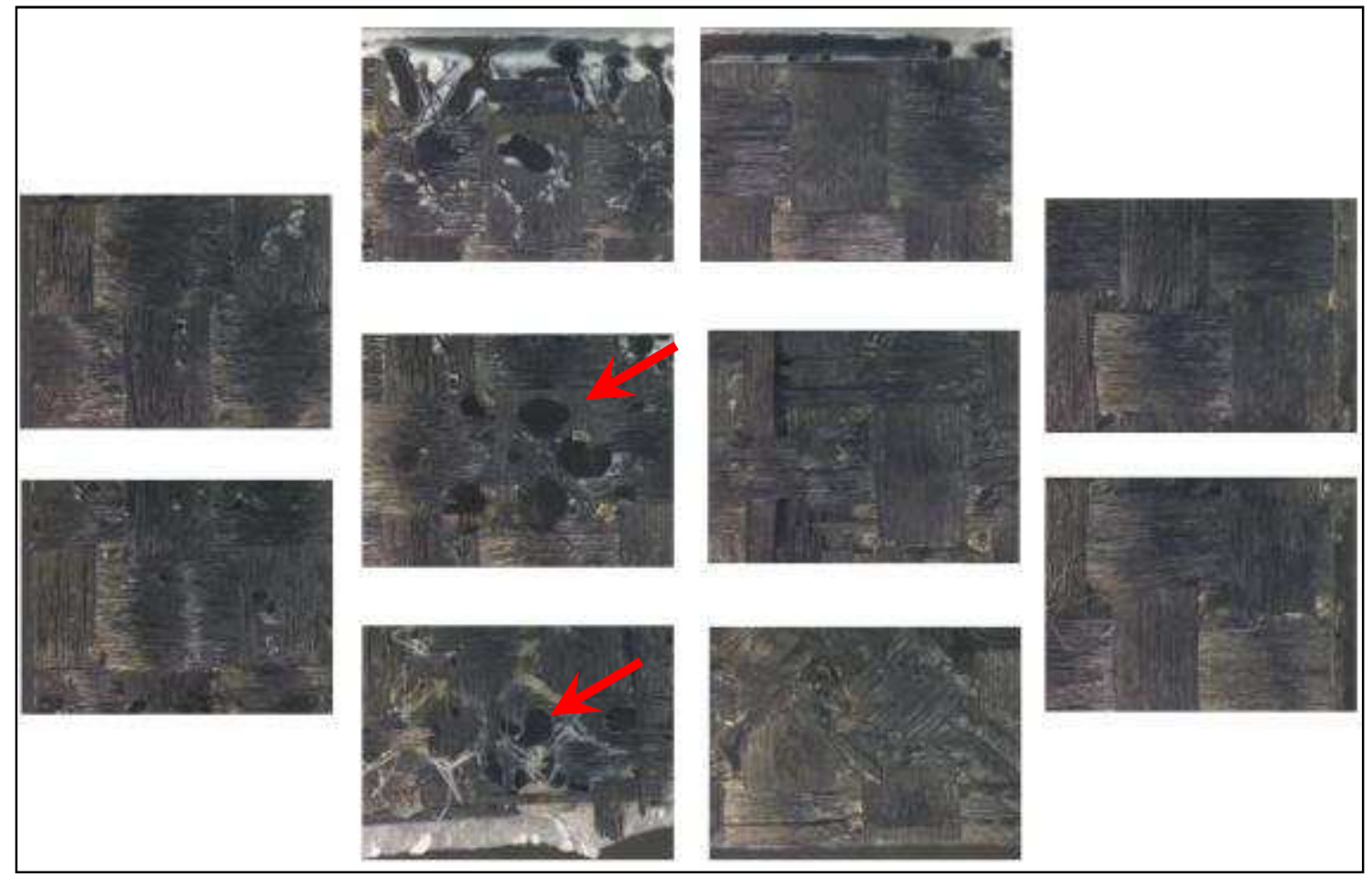

(b)

Figura 4.19 - Representação parcial da área pós-ensaio do CDP 1115 (V) onde se tem uma face (a) e a face oposta (b). Em ambas as faces é possível observar vazios na superfície de interface (setas vermelhas). 
A Figura 4.19b apresenta à face oposta a face mostrada na figura 4.19a. Contudo, esta face oposta apresenta as mesmas características já salientadas na Figura 4.19a.

Outro CDP selecionado para esta análise na condição "impactado + condicionado" é o $4(1+C)$. A Figura 4.20a e b mostram as duas faces pós-ensaio para este CDP. Observa-se na Figura 4.20a com parte do filme adesivo, uma superfície uniforme nas bordas 1 e 3 e no centro 5 (exceto pela presença de pequenos vazios neste último) enquanto que nas bordas 2 e 4 nota-se uma maior deterioração do filme adesivo. Essa maior deterioração nas bordas 2 e 4, pode ser atribuída a perda de resistência do filme adesivo devido a exposição a condições higrotérmicas e principalmente pelo fato destas bordas estarem localizadas nas regiões com maiores tensões de cisalhamento e tensões fora do plano ("peel stress") decorrentes do ensaio de flexão sob quatro pontos. Na face oposta representada na Figura 4.20b, notam-se resquícios do filme adesivo e ausência de danos nas fibras.

llustrou-se para o EPX somente esses dois CDPs para estereoscopia da superfície de fratura, pois representam as características comuns encontradas nas outras amostras, principalmente a maior deterioração do filme adesivo para os CDPs submetidos ao condicionamento higrotérmico.

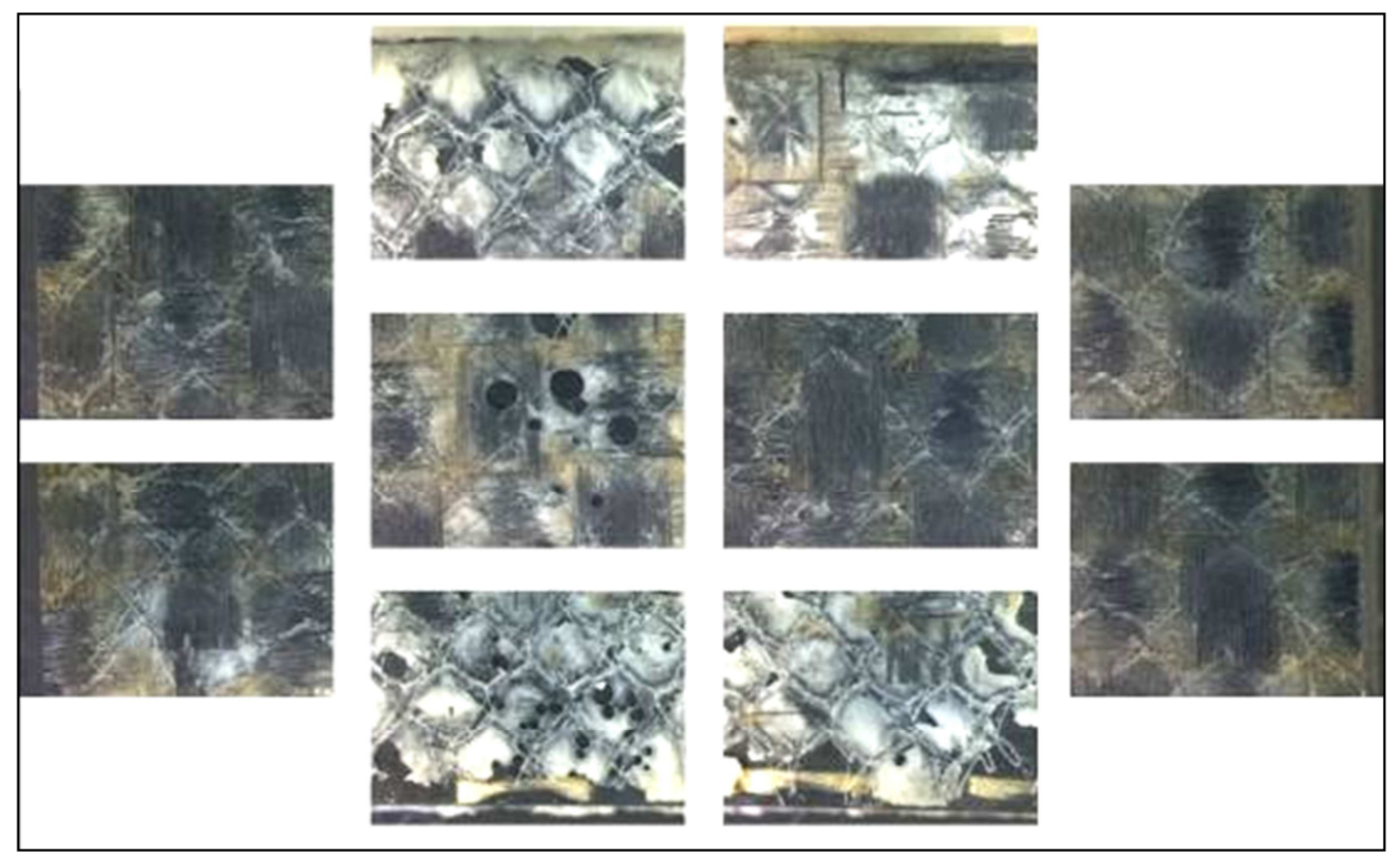




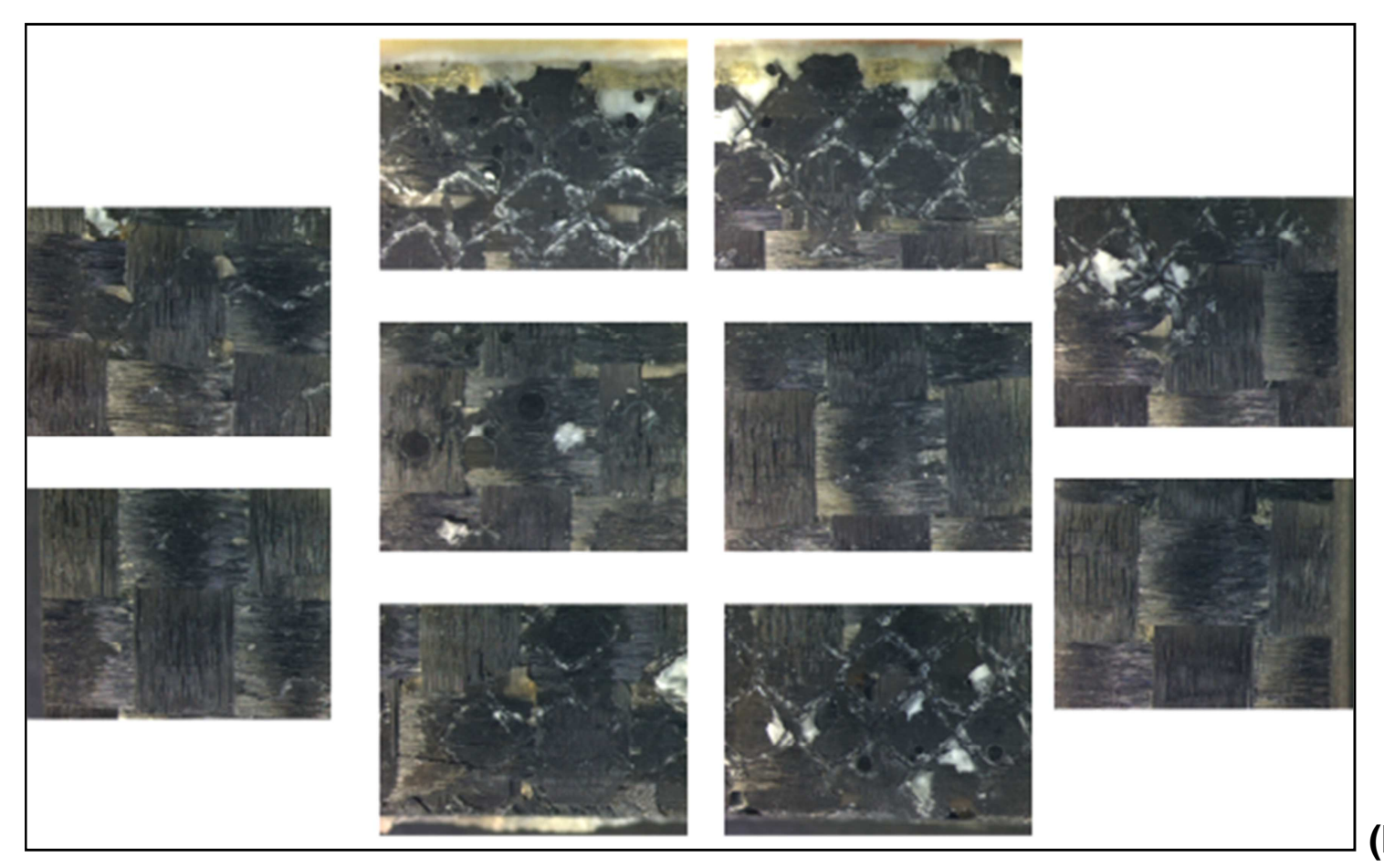

(b)

Figura 4.20 - Representação parcial da área pós-ensaio do CDP $4(\mathrm{I}+\mathrm{C})$ onde se tem uma face (a) e a face oposta (b).

A análise estereoscópica apenas contribui para a visualização em maiores detalhes de características já observadas nas superfícies de união das juntas através da inspeção visual, mas sem acrescentar novas informações que somente foram obtidas através de análises em escala microscópica como descritas no decorrer deste texto.

\subsubsection{Análise microscópica da falha (microscópio óptico de reflexão)}

Para a análise via microscópio óptico de reflexão, a vista das amostras retiradas das juntas seccionadas recebeu a denominação vista longitudinal para a face originada após corte da junta ao longo do comprimento e a denominação vista transversal para a face originada após corte da junta ao longo da largura. 


\subsubsection{Junta Simplesmente Impactada: Região Central, Vista Longitudinal}

Iniciando a análise para as amostras de PPS-C, a Figura 4.21a mostra esquematicamente a estratégia de retirada de uma amostra avaliada por microscopia óptica de luz refletida a partir de uma junta PPS-C na condição de simplesmente impactada, removida na região central e observada o corte longitudinal.

A Figura 4.21b mostra uma ampla presença de vazios/bolhas/poros distribuídos na região de enriquecimento proposital de PPS pela adição de filme puro do polímero, na camada de revestimento de PPS-V e em regiões do núcleo dos aderentes (PPS-C) junto à lâmina de revestimento dos laminados aderentes, ou seja, no entorno da linha de solda assim como trincas intralaminares transversais.

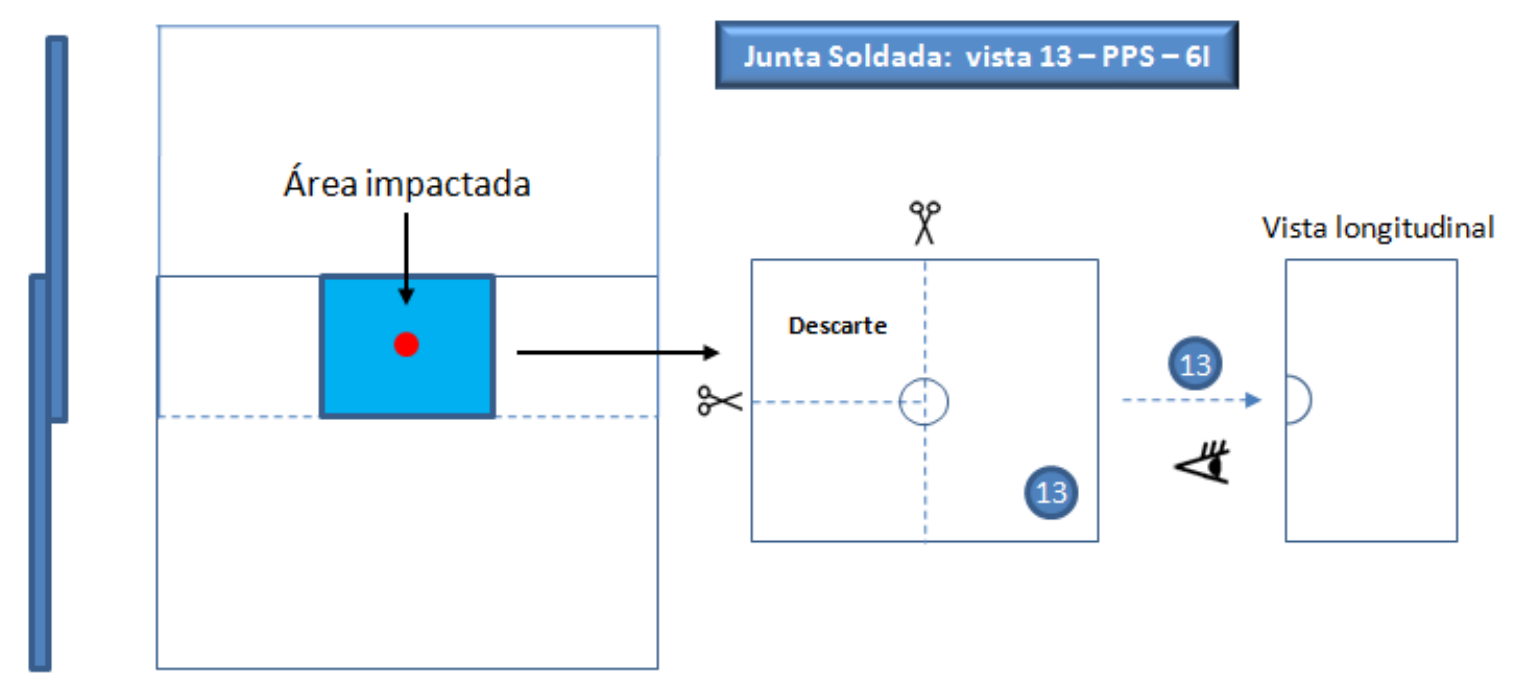

(a) 


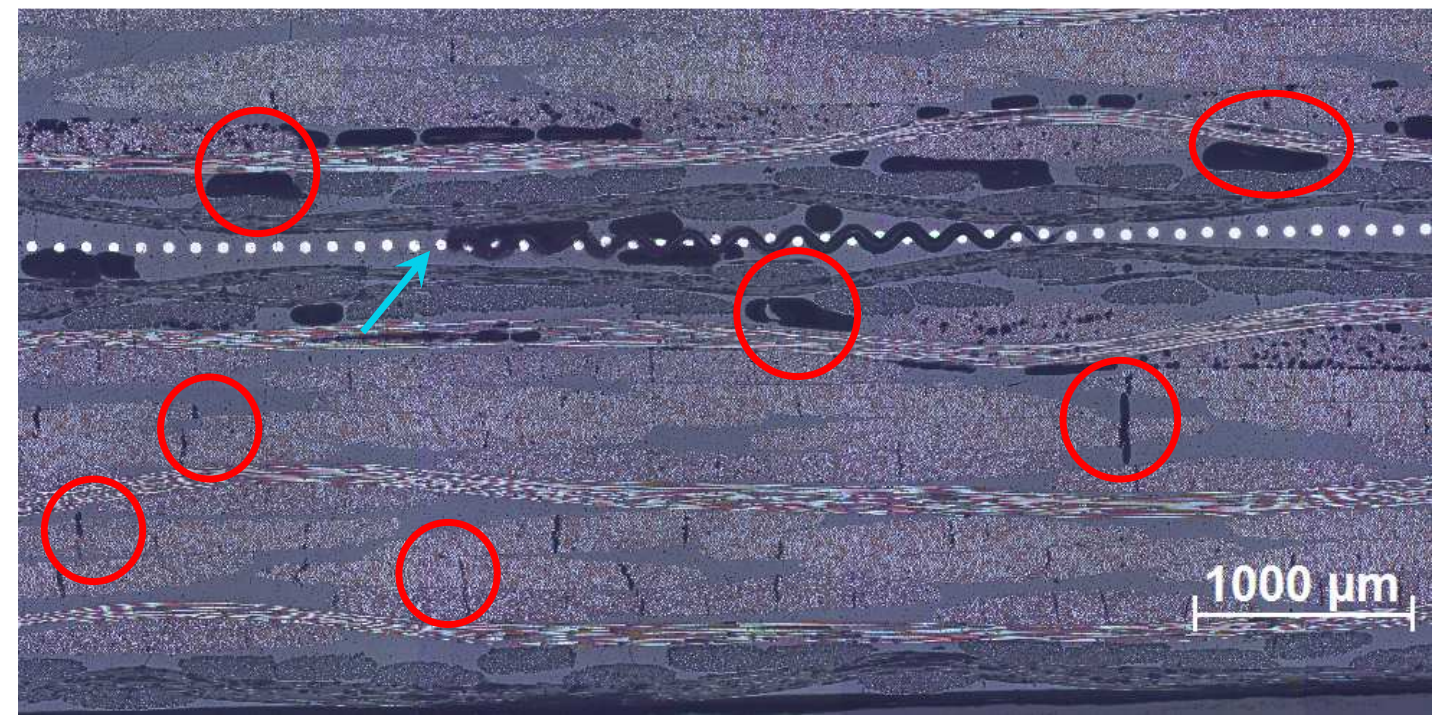

(b)

Figura 4.21 - (a) Esquema de retirada da amostra materialográfica codificada 13 - PPS - 6l; (b) Microfotografia da junta PPS na condição apenas impactada, com a face de impacto inferior, sendo o local de observação central, e direção de observação longitudinal à junta. Várias trincas e bolhas são indicadas por círculos vermelhos, e o inserto metálico imerso em zona rica no polímero puro PPS-V é apontado por uma seta azul.

\subsubsection{Junta Simplesmente Impactada: Região Central, Vista Transversal}

A Figura 4.22a mostra esquematicamente a estratégia de retirada de uma amostra avaliada por microscopia óptica de luz refletida a partir de uma junta PPS-C na condição de simplesmente impactada, diferenciada da imagem anterior somente pelo fato de que a vista do dano analisado se dá numa direção deslocada de $90^{\circ}$ relativamente àquela precedente.

A Figura 4.22b mostra uma ampla presença de vazios/bolhas de várias dimensões distribuídos na região de enriquecimento proposital de PPS pela adição de filme puro do polímero, na camada de revestimento de PPS-V e em regiões do núcleo dos aderentes (PPS-C) junto à lâmina de revestimento dos laminados aderentes, ou seja, no entorno da linha de solda, identicamente como visualizado na figura anterior, de idêntica região da mesma junta termoplástica, porém visualizada ortogonalmente àquela. 


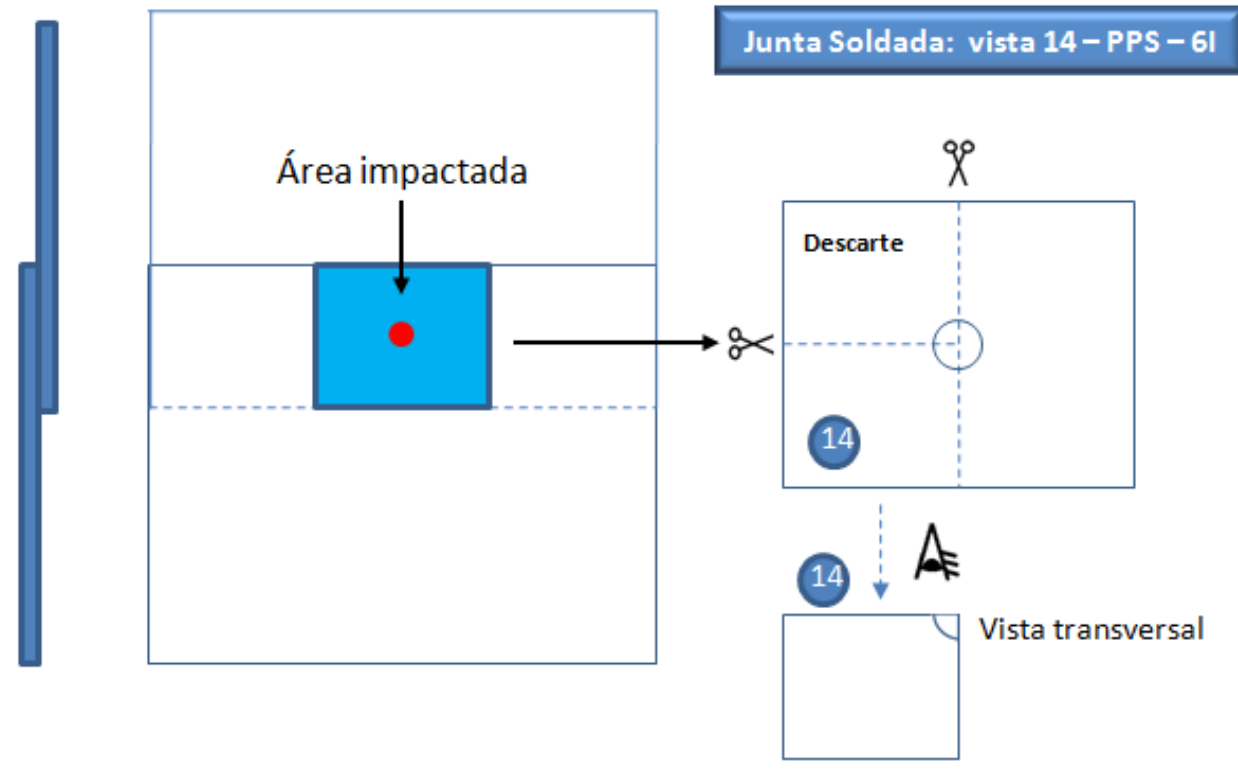

(a)

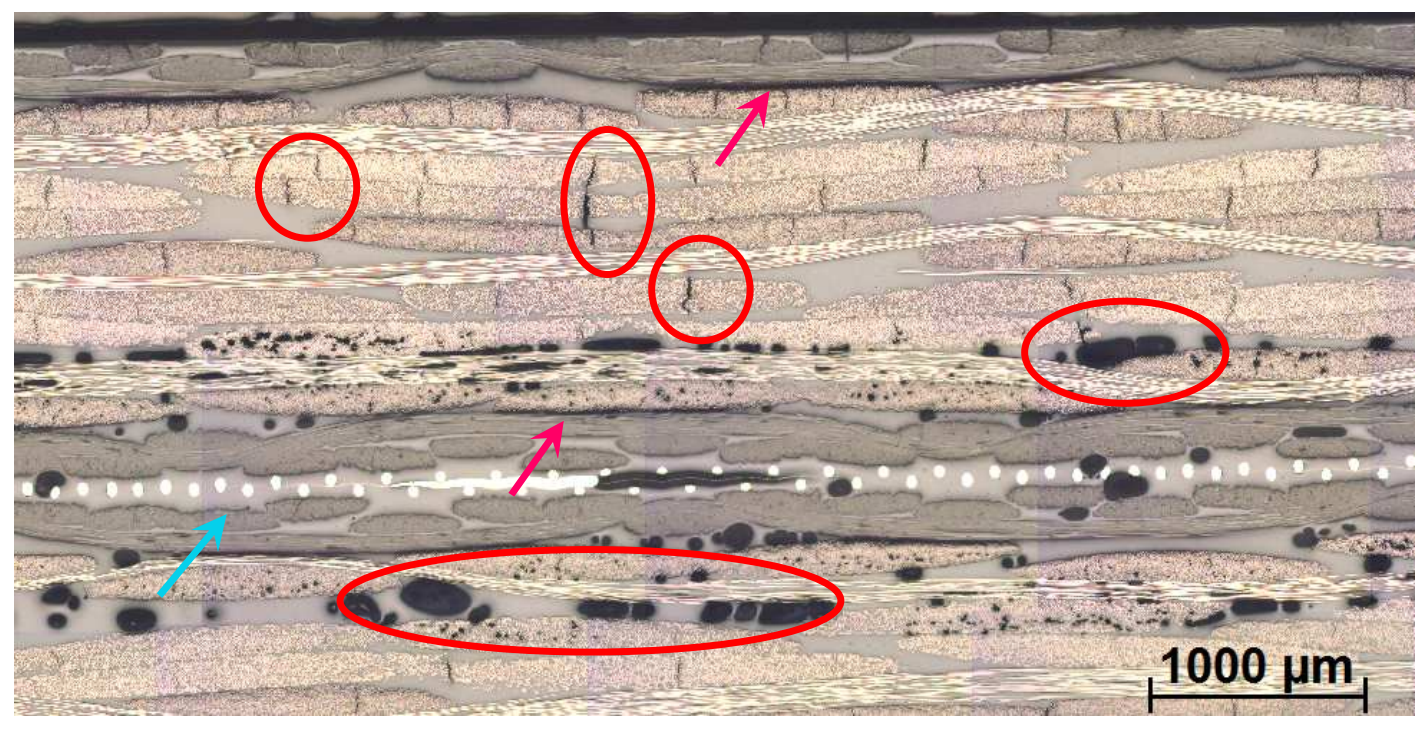

(b)

Figura 4.22 - (a) Esquema de retirada da amostra materialográfica codificada 14 - PPS - 6l; (b) Microfotografia da junta PPS na condição apenas impactada, com a face de impacto inferior, sendo o local de observação central, e direção de observação transversal à junta. Várias trincas e bolhas são indicadas por círculos vermelhos, e o inserto metálico imerso em zona rica no polímero puro PPS-V é apontado por uma seta azul. Potenciais delaminações estão setadas em magenta.

Trincas intralaminares transversais aparecem em muito maior quantidade com relação à vista anterior desta mesma junta (Fig. 4.21), aparentando serem bem mais críticas e predominam no laminado não-impactado (superior, ou acima da malha metálica). Há alguma evidência de delaminações na interface entre os laminados aderentes e a área rica em PPS que envolve a malha metálica, assim com entre o 
laminado núcleo de PPS-C e a camada de revestimento de PPS-V externa à junta, porém tal hipotetização não é passível de confirmação por intermédio da técnica de inspeção ora empregada.

\subsubsection{Junta Simplesmente Impactada: Região de Borda, Vista Longitudinal}

A Figura 4.23a mostra esquematicamente a estratégia de retirada de uma amostra avaliada por microscopia óptica de luz refletida a partir de uma junta PPS-C na condição de simplesmente impactada. Diferentemente das duas figuras anteriores, ela se refere à vista materialográfica tomada numa das bordas laterais da junta termoplástica soldada por resistência elétrica.

As Figuras $4.23 \mathrm{~b}$ e $4.23 \mathrm{c}$ mostram uma grande quantidade de enormes vazios/bolhas concentrados na linha de soldagem (região enriquecida propositadamente em PPS-V) e presentes também nos aderentes (o que inclui os núcleos de laminados PPS-C), em especial no laminado não-impactado. São destacados dois vazios alongados gerados na manufatura da junta, originados já quase na meia espessura do núcleo de PPS do aderente impactado.

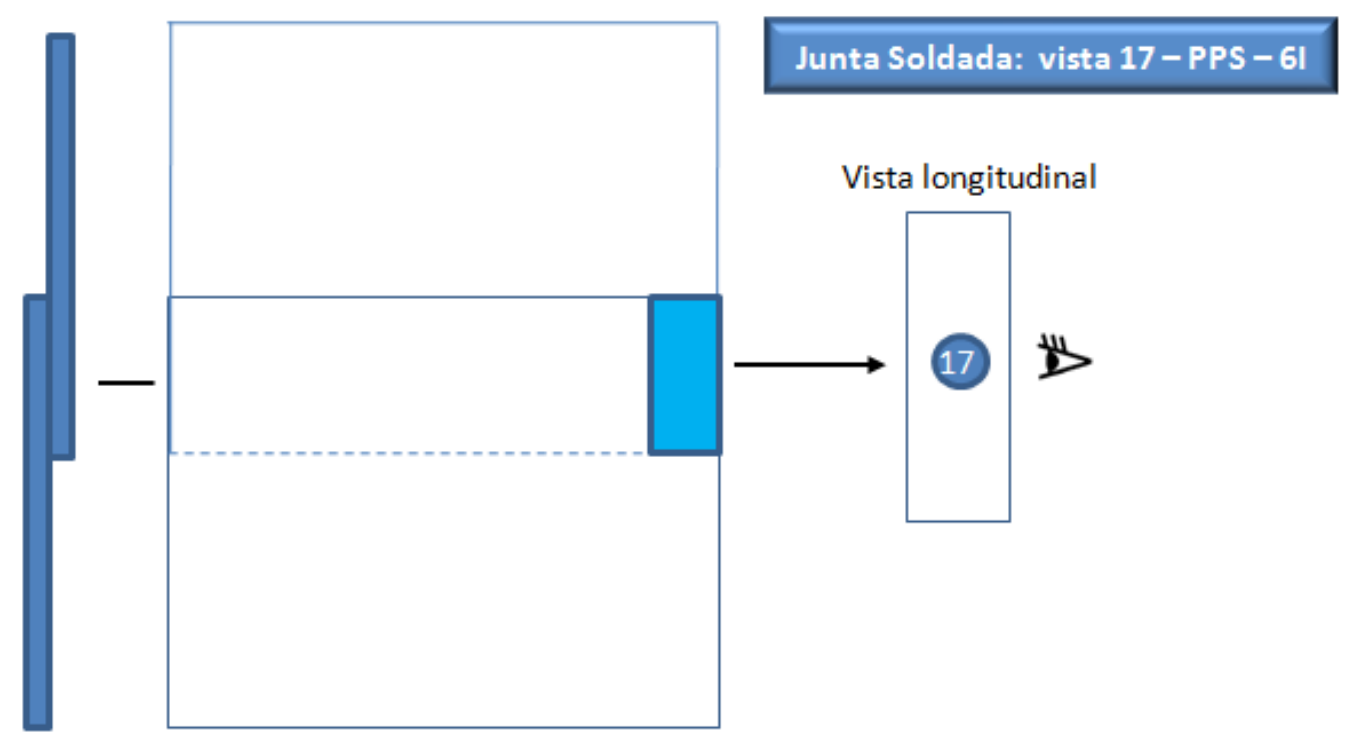

(a) 


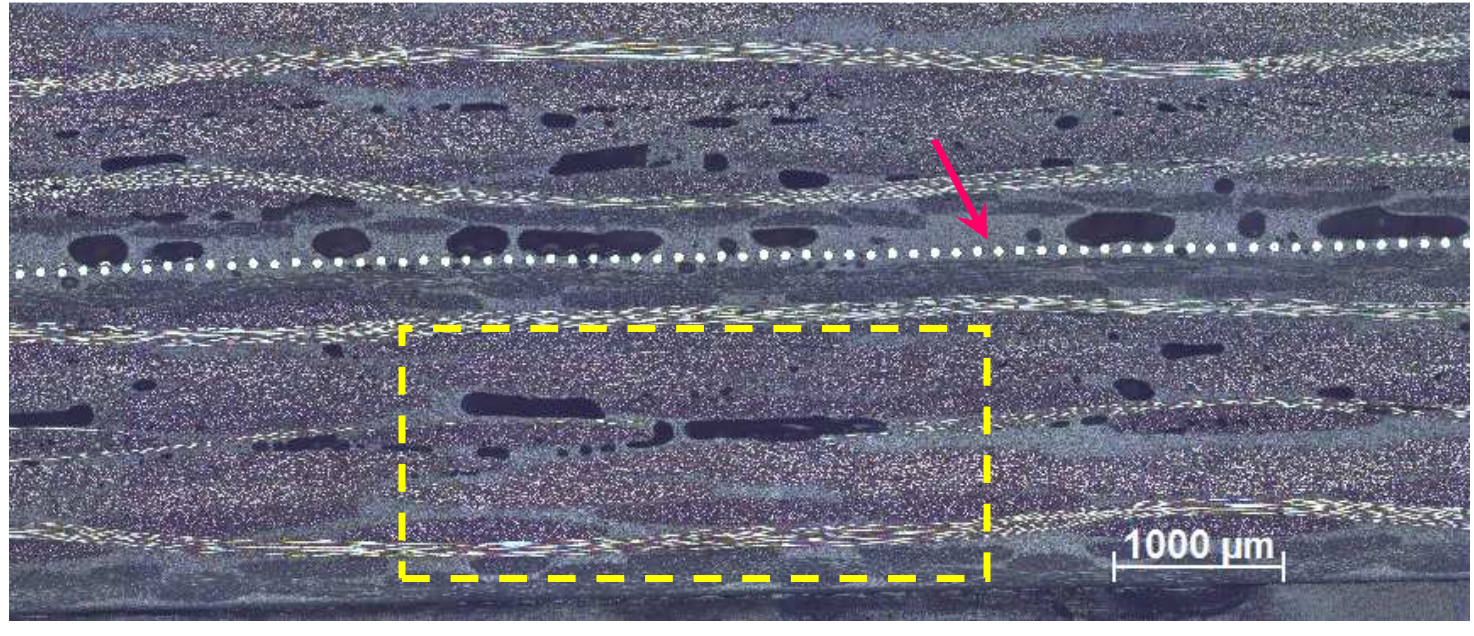

(b)

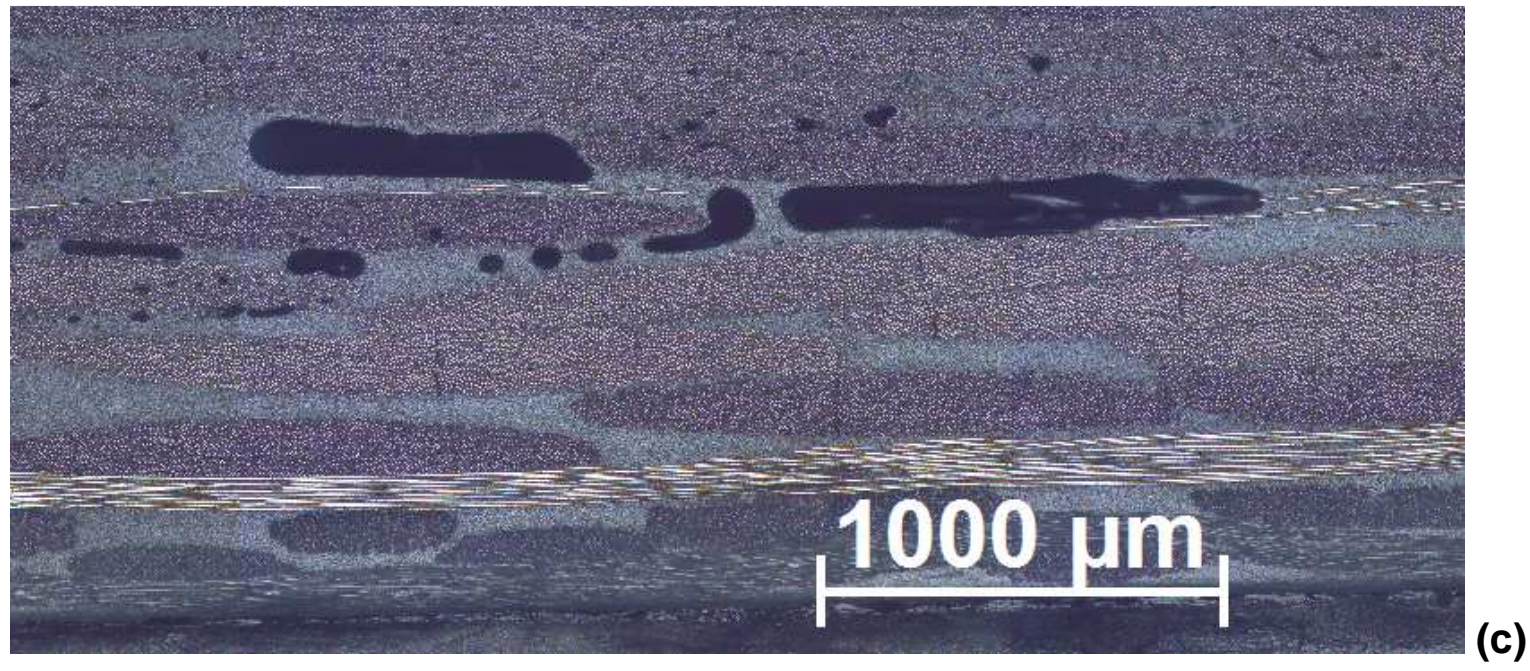

Figura 4.23 - (a) Esquema de retirada da amostra materialográfica codificada 17 - PPS - 6/; (b) Microfotografia da junta PPS na condição apenas simplesmente impactada, com a face de impacto inferior (abaixo da malha metálica), sendo o local de observação a borda lateral da junta, e direção de observação longitudinal à junta. Grande quantidade de bolhas/vazios é observada, sendo algumas delas (mais alongadas) destacadas em (c). O inserto metálico é apontado por uma seta magenta.

Algumas trincas intralaminares transversais estão presentes nos laminados aderentes como decorrência da carga dinâmica aplicada transversalmente à área de sobreposição da junta de cisalhamento, sendo mais bem observadas sob maior ampliação de imagem na Figura 4.23c, que corresponde ao aderente impactado. 


\subsubsection{Junta Impactada e Envelhecida Higrotermicamente: Região Central, Vista Longitudinal}

A Figura 4.24a mostra esquematicamente a estratégia de retirada de uma amostra avaliada por microscopia óptica de luz refletida a partir de uma junta PPS-C na condição de impactada e subseqüentemente exposta a condicionamento higrotérmico.

Nota-se na Figura 4.24 a restrita presença de alguns vazios/bolhas nas proximidades linha de soldagem, indicando uma melhor qualidade de junta comparativamente àquelas ilustradas nas Figuras 4.21 e 4.22. Isso, em alguma extensão, afeta negativamente a análise dos resultados comparativos entre juntas simplesmente impactada (I) e impactada+condicionada $(I+C)$, visto que, aparentemente, a de melhor qualidade quanto ao processo de fabricação (Fig. 4.24) foi sujeita a condições muito mais agressivas que as juntas de pior qualidade (ilustrada nas Figs 4.21, 4.22 e 4.23), e vice-e-versa.

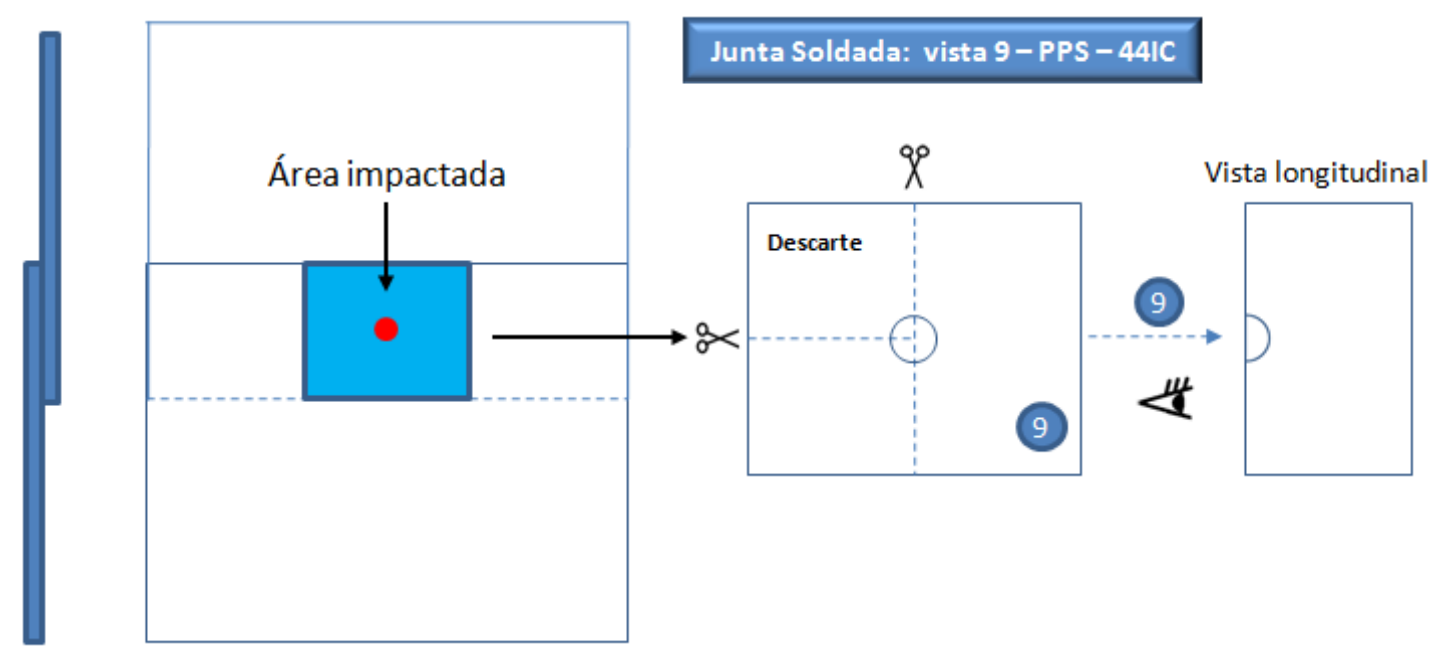

(a) 

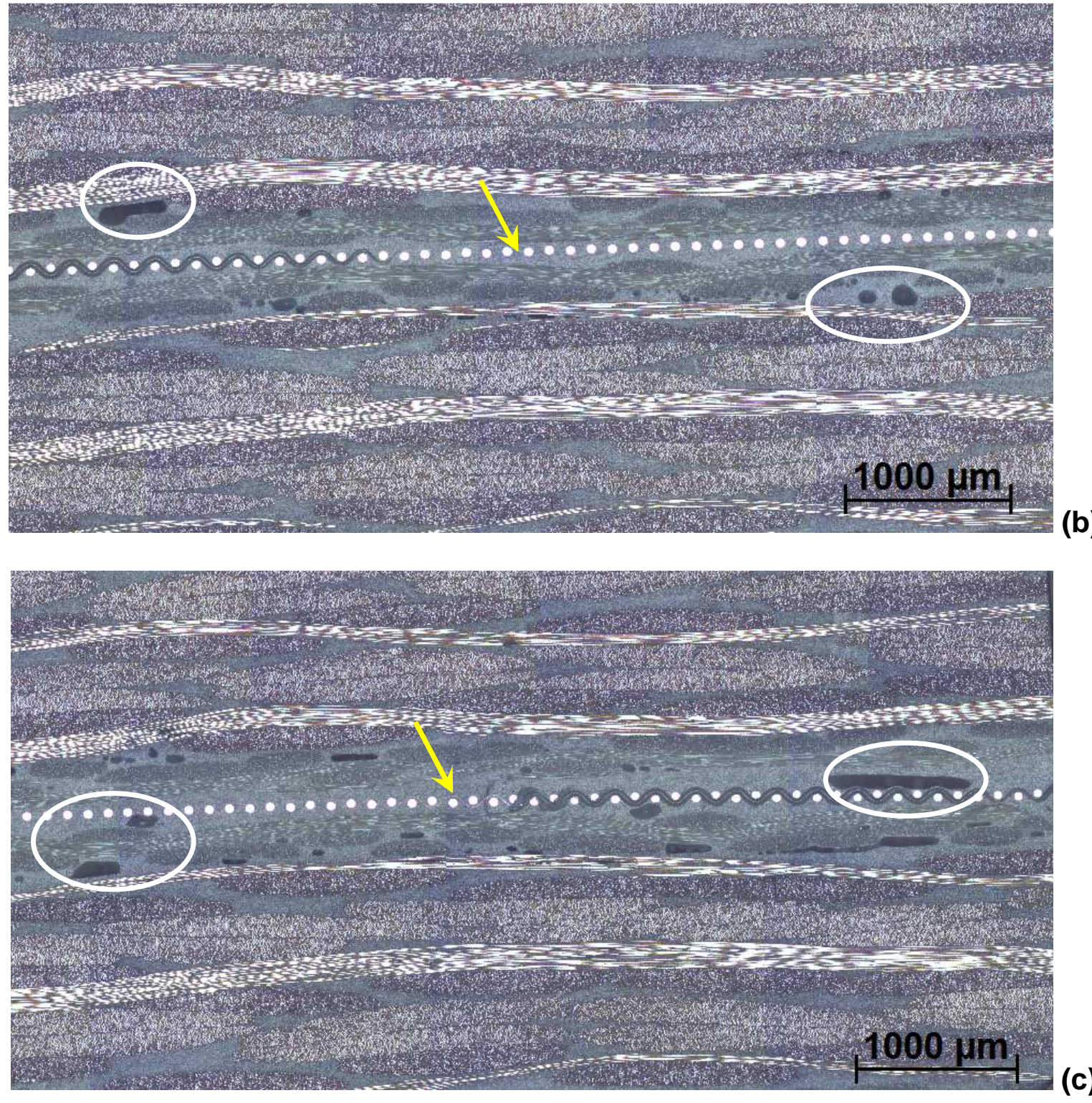

Figura 4.24 - (a) Esquema de retirada da amostra materialográfica codificada $9-P P S-44$ IC; (b) Microfotografia da junta PPS-C na condição impactada+condicionada, com a face de impacto inferior, sendo o local de observação central, e direção de observação longitudinal à junta, onde o inserto metálico é apontado por uma seta amarela; (c) Bolhas/vazios detectados são destacadas em elipses e círculos brancos, respectivamente.

\subsubsection{Junta Impactada e Envelhecida Higrotermicamente: Região Central, Vista Transversal}

A Figura 4.25a mostra esquematicamente a estratégia de retirada de uma amostra avaliada por microscopia óptica de luz refletida a partir de uma junta PPS-C 
na condição de impactada e subseqüentemente condicionada higrotermicamente, que se diferencia da imagem anterior somente pelo fato de que a vista do dano se dá em uma direção deslocada de $90^{\circ}$ relativamente àquela antecedente.

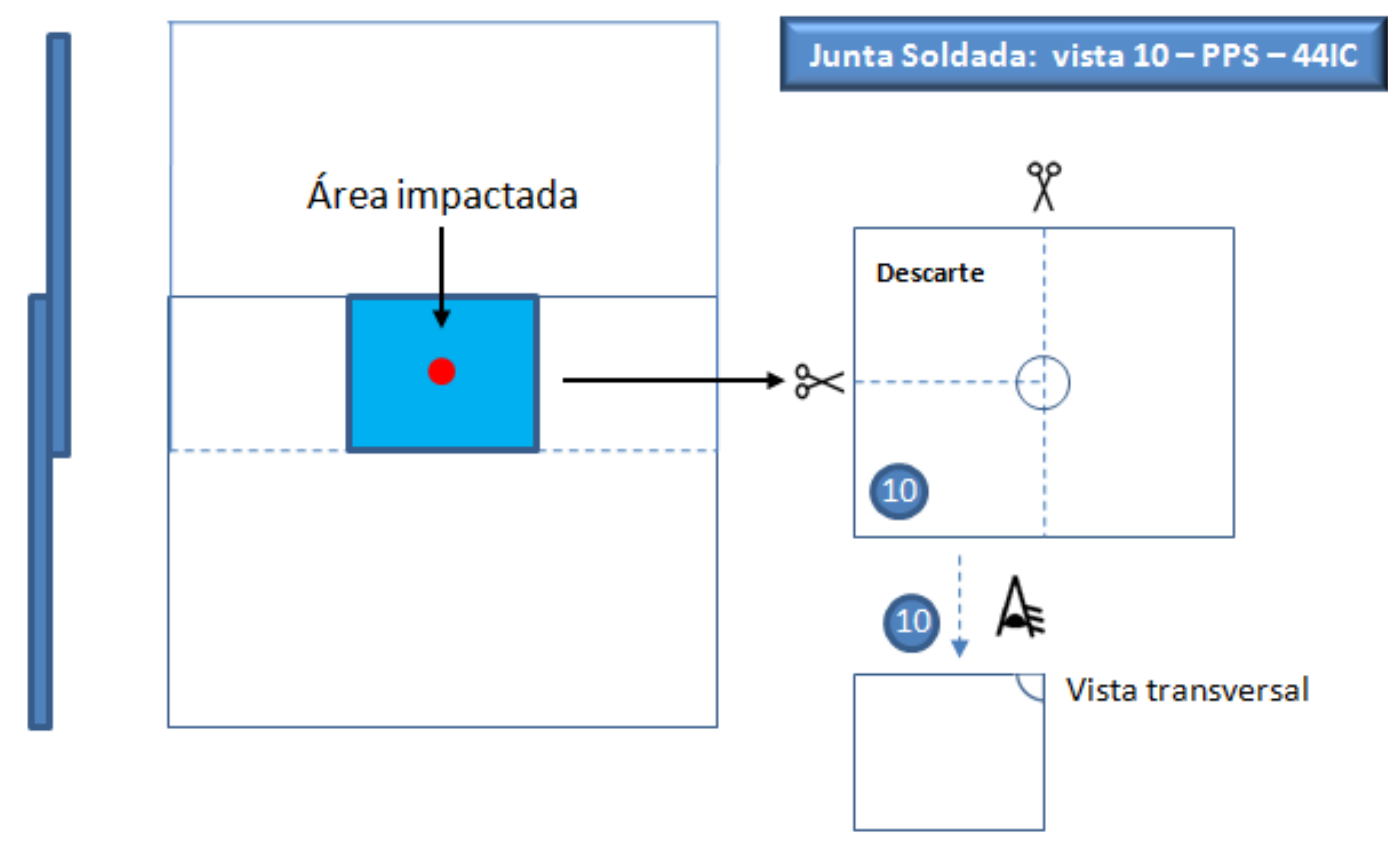

(a)

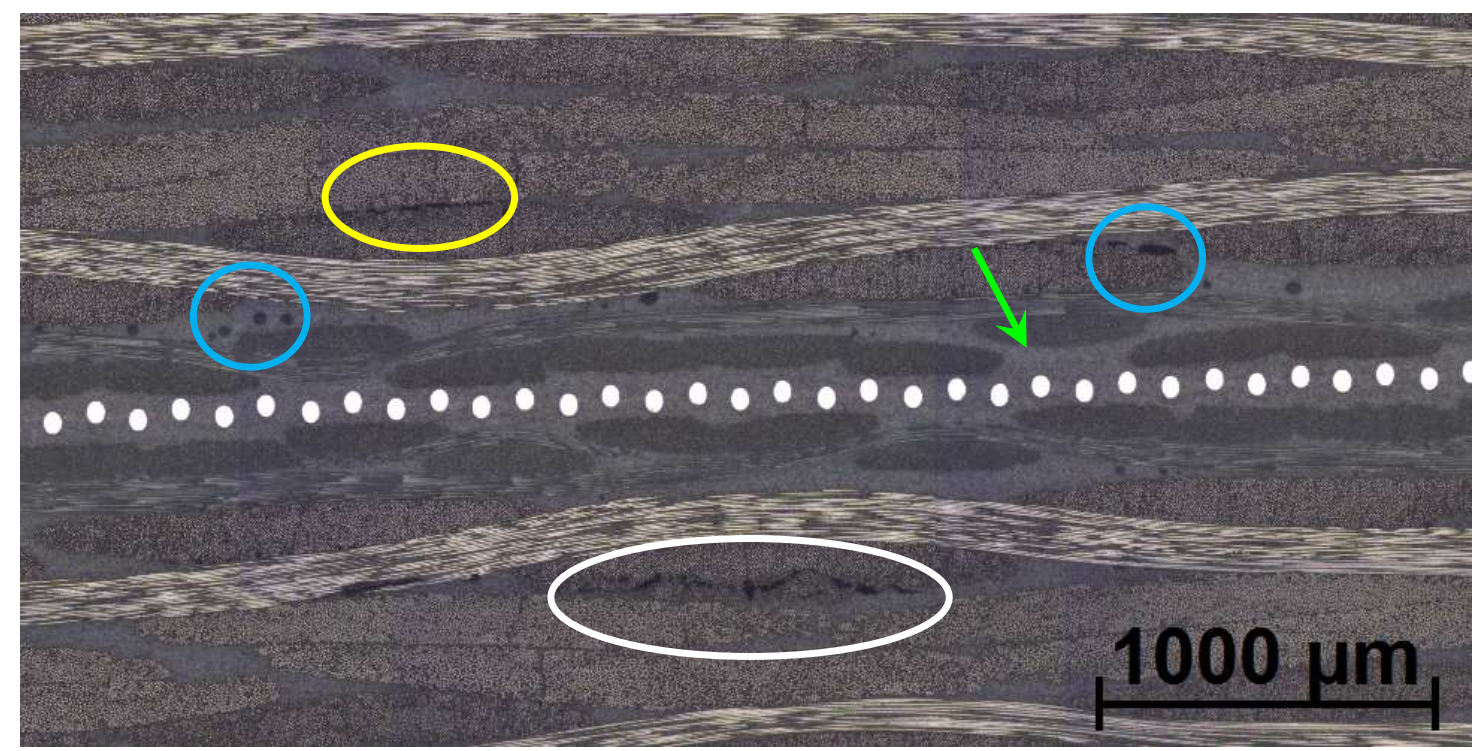

(b) 


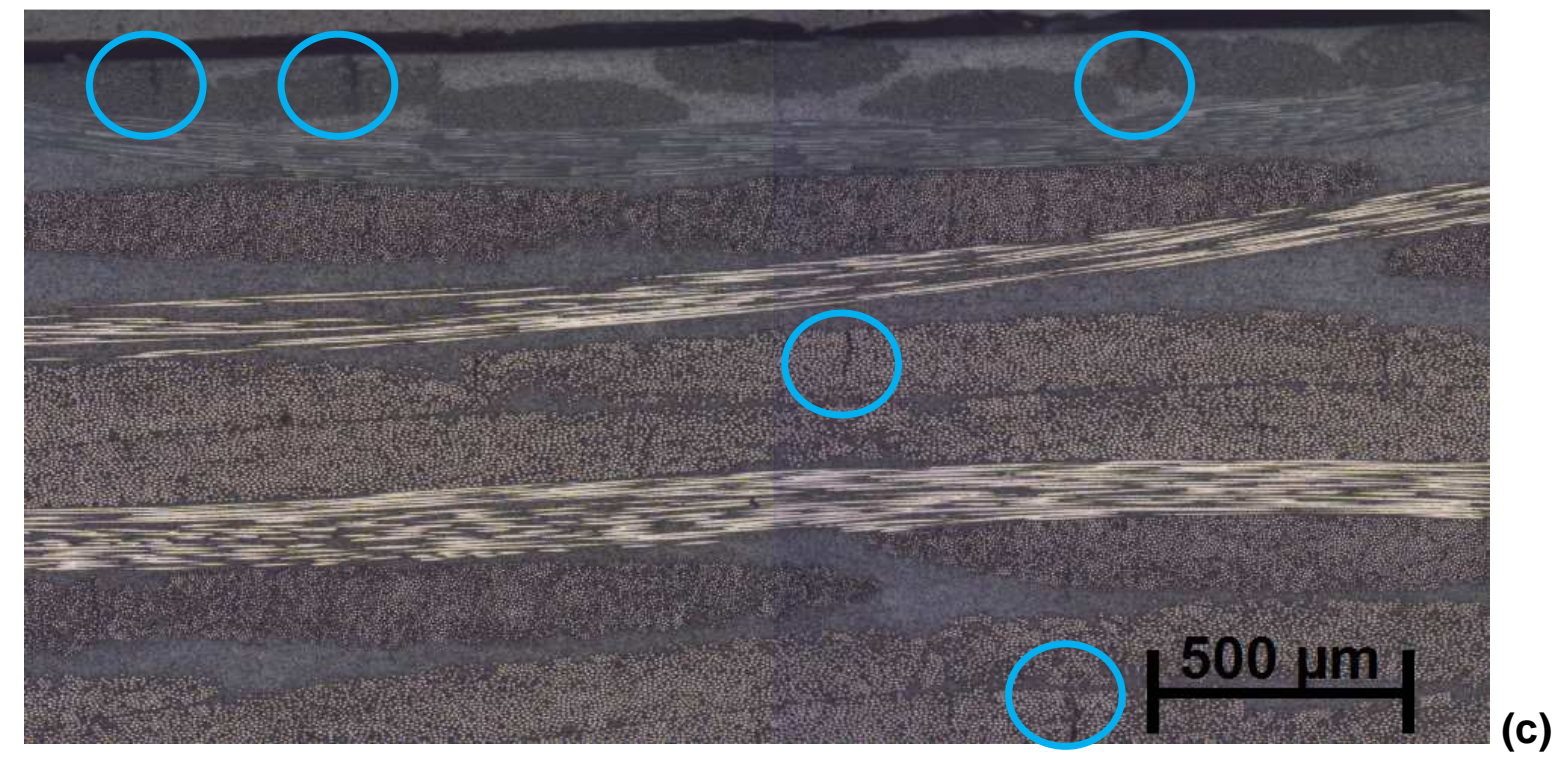

Figura 4.25 - (a) Esquema de retirada da amostra materialográfica codificada 10 - PPS - 44 $I C$; (b) Junta PPS-C na condição impactada+condicionada, com a face de impacto superior, sendo o local de observação central, e direção de observação transversal à junta; Potenciais trincamentos intralaminares longitudinais podem ser postulados (elipse amarela). Uma extensiva trinca horizontal é destacada por uma elipse branca na região já contida pelo núcleo do laminado ou aderente não-impactado de PPS-C; (c) Poucas trincas intralaminares transversais são indicadas por círculos/elipses azuis.

Nota-se a limitada presença de vazios/bolhas/poros (na forma de alguns clusters) na linha de soldagem e cercanias mais próximas (camada de revestimento de PPS-V). Trincas intralaminares transversais e sinais de algumas longitudinais são verificados na Figura 4.25c. Há ocorrência de uma trinca horizontal já no interior do núcleo de PPS-C do aderente não-impactado.

\subsubsection{Junta Impactada e Envelhecida Higrotermicamente: Região de Borda, Vista Longitudinal}

A Figura 4.26a mostra esquematicamente a estratégia de retirada de uma amostra avaliada por microscopia óptica de luz refletida a partir de uma junta PPS-C na condição de impactada+condicionada $(\mathrm{I}+\mathrm{C})$. Diferentemente das duas figuras anteriores, ela se refere à vista materialográfica tomada numa das bordas laterais da junta termoplástica soldada. 
A ampla presença de vazios/bolhas homogeneamente distribuídos nas circunvizinhanças da linha de soldagem, o que inclui as correspondentes camadas mais próximas dos laminados aderentes, chegando mesmo a invadir os núcleos dos laminados de PPS-C (denotando o superaquecimento tipicamente associado ao efeito de borda), além de uma possível delaminação logo abaixo da malha metálica de soldagem, em posição contida no aderente submetido ao impacto e uma não menor trinca intralaminar transversal no aderente não-impactado, são prontamente identificados na Figura 4.26.

Merece ser destacado que, diferentemente dos espécimes termorrígidos EPX-C, os quais foram extraídos a partir uma única peça obtida pela colagem de duas longas placas laminadas, de modo a gerar uma única faixa de adesão por sobreposição dos laminados, os espécimes termoplásticos PPS-C foram manufaturados individualmente.

\section{Junta Soldada: vista 7-PPS - 44IC}

Vista longitudinal

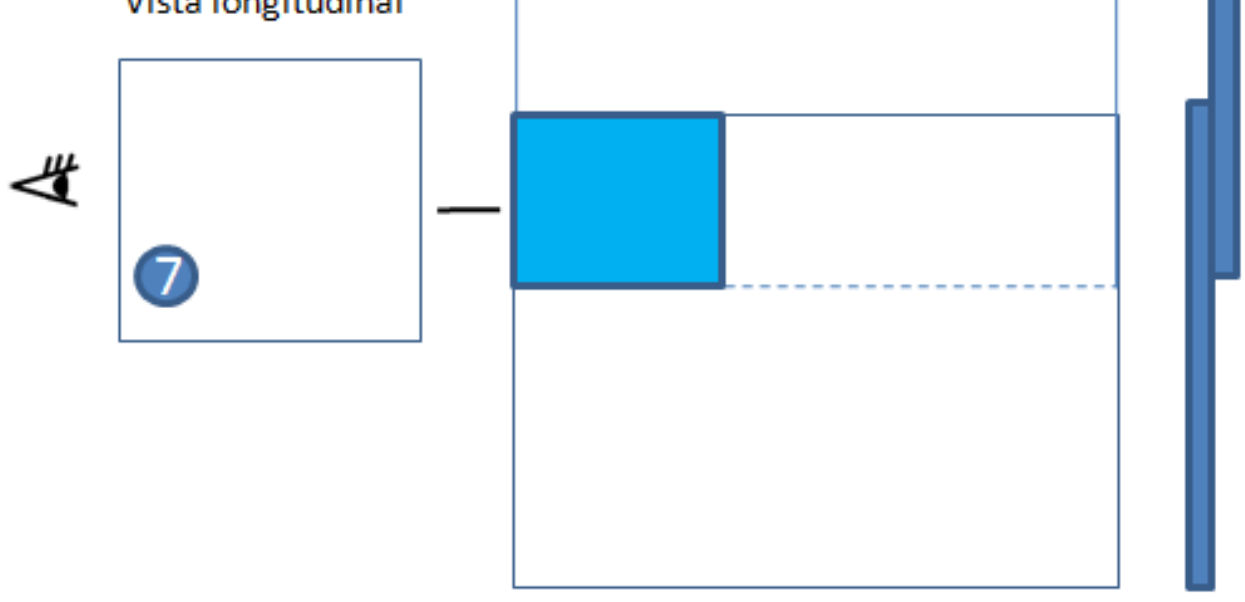

(a) 


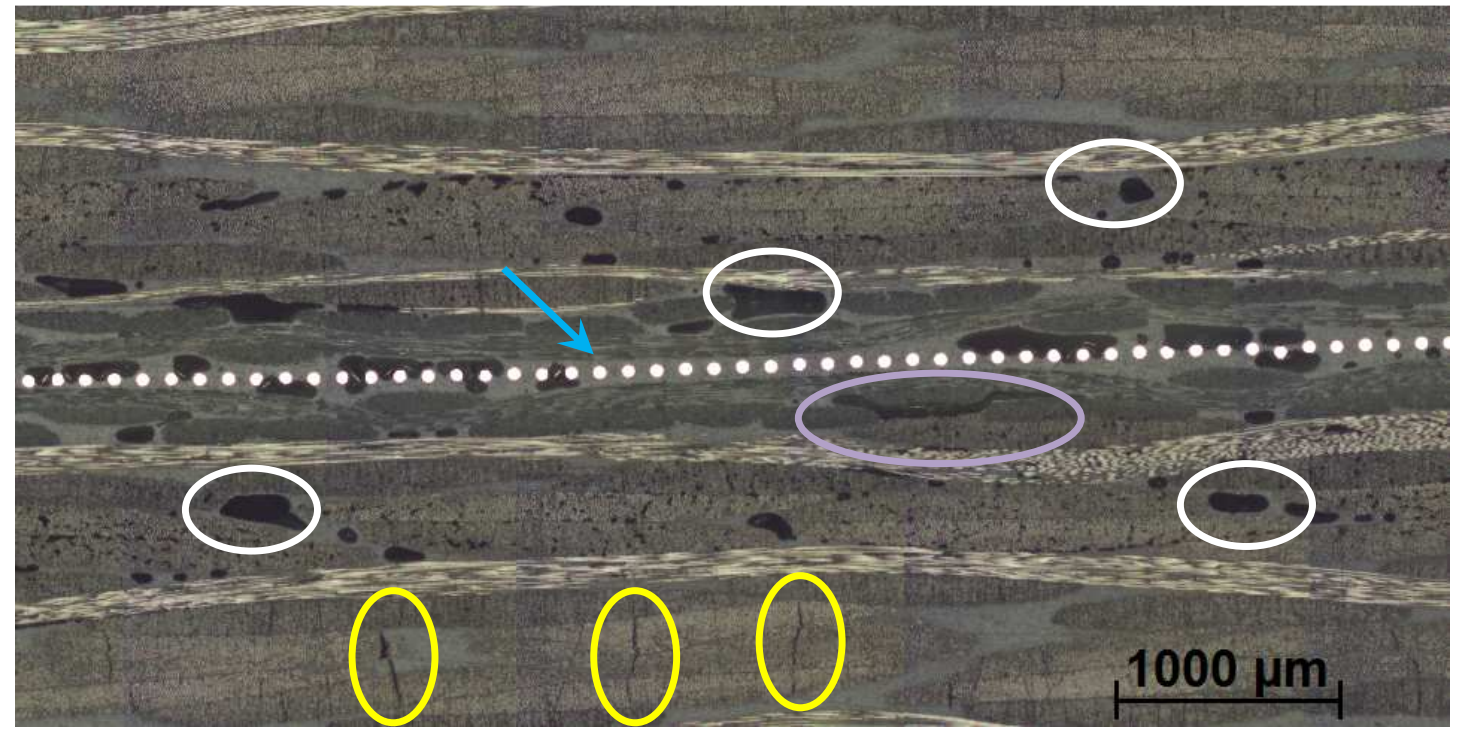

(b)

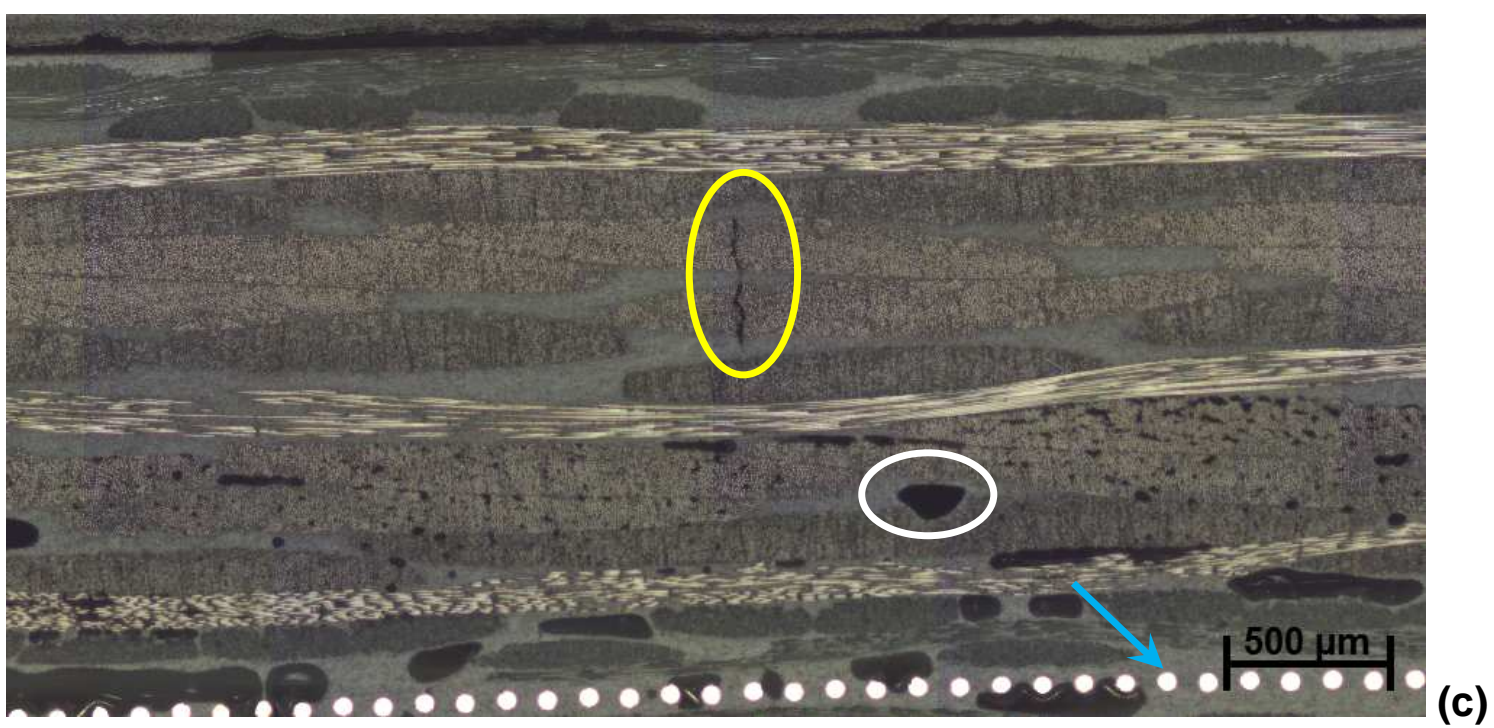

Figura 4.26 - (a) Esquema de retirada da amostra materialográfica codificada 7 - PPS - 44 IC; (b) Microfotografia da junta PPS-C na condição impactada+condicionada, com a face de impacto inferior, sendo o local de observação a borda lateral da junta, e direção de observação longitudinal à junta. Uma considerável presença de bolhas/vazios é destacada por elipses brancas é observada (c). Nota-se a presença de uma trinca horizontal (contida numa elipse roxa) não passível de ser confirmada pela técnica materialográfica empregada; (c) Trincamento intralaminar de proporções substanciais localizado por uma elipse amarela, com o inserto metálico apontado por uma seta azul.

O relativamente baixo desempenho mecânico exibido pela classe de juntas termoplásticas PPS-C neste trabalho, frente às termorrígidas EPX-C, muito certamente tenha resultado, em grande proporção, da baixa qualidade do produto final de soldagem nas suas duas porções laterais dos espécimes, isto ainda quando não foi o próprio centro das juntas sobrepostas que apresentou tais deficiências. 
Com base nas vistas das seções materialográficas de corte transversal e longitudinal dos espécimes PPS-C apenas impactados e impactados e condicionados higrotermicamente, proximamente à borda lateral dos espécimes, e juntamente à região de impacto central impingido aos mesmos, foi possível concluir também que:

$\checkmark$ A seção de corte transversal nas bordas laterais dos espécimes, onde ocorre a entrada e saída de corrente durante a soldagem, é onde foram encontradas as maiores quantidades de vazios na linha de solda junto à malha de aço inoxidável, embora em certas amostras até mesmo a região central da junta estava comprometida neste sentido. Observou-se também que houve até mesmo desconsolidação do polímero PPS nas primeiras camadas de PPS-C do núcleo do laminado mais próximos da linha de solda;

$\checkmark$ A seção transversal de corte de amostras seccionadas juntos ao centro da junta sobreposta exibe, em geral, uma menor quantidade de bolhas/vazios, e a quase ausência de desconsolidação dos aderentes nas camadas próximas à linha de soldagem;

$\checkmark$ Nos espécimes seccionados no centro da área impactada foi observada uma substancial quantidade de micro-trincas transversais.

\subsubsection{Junta Simplesmente Impactada: Região Central, Vista Longitudinal}

Dando continuidade à análise, agora para o EPX-C, a Figura 4.27a mostra esquematicamente a estratégia de retirada de uma amostra avaliada por microscopia óptica de luz refletida a partir de uma junta EPX-C na condição de simplesmente impactada (I).

Extensos danos causados pelo impacto aplicado de $10 \mathrm{~J}$, em especial no laminado traseiro/posterior, não-impactado, são claramente observados na junta sobreposta termorrígida. Os danos ocorrem na forma de longas delaminações associadas a numerosos trincamentos intralaminares transversais (ao longo da espessura dos aderentes). Mesmo não sendo perfeita devida à presença de 
bolhas/vazios originados muito provavelmente no processo de manufatura da junta, a linha de colagem, sob a perspectiva de uma análise materialográfica de relativamente baixa magnitude de ampliação de imagens da seção de corte longitudinal da área de sobreposição da junta de cisalhamento, parece permanecer íntegra no que se refere a potenciais danos criados pelo evento de impacto de baixa energia.

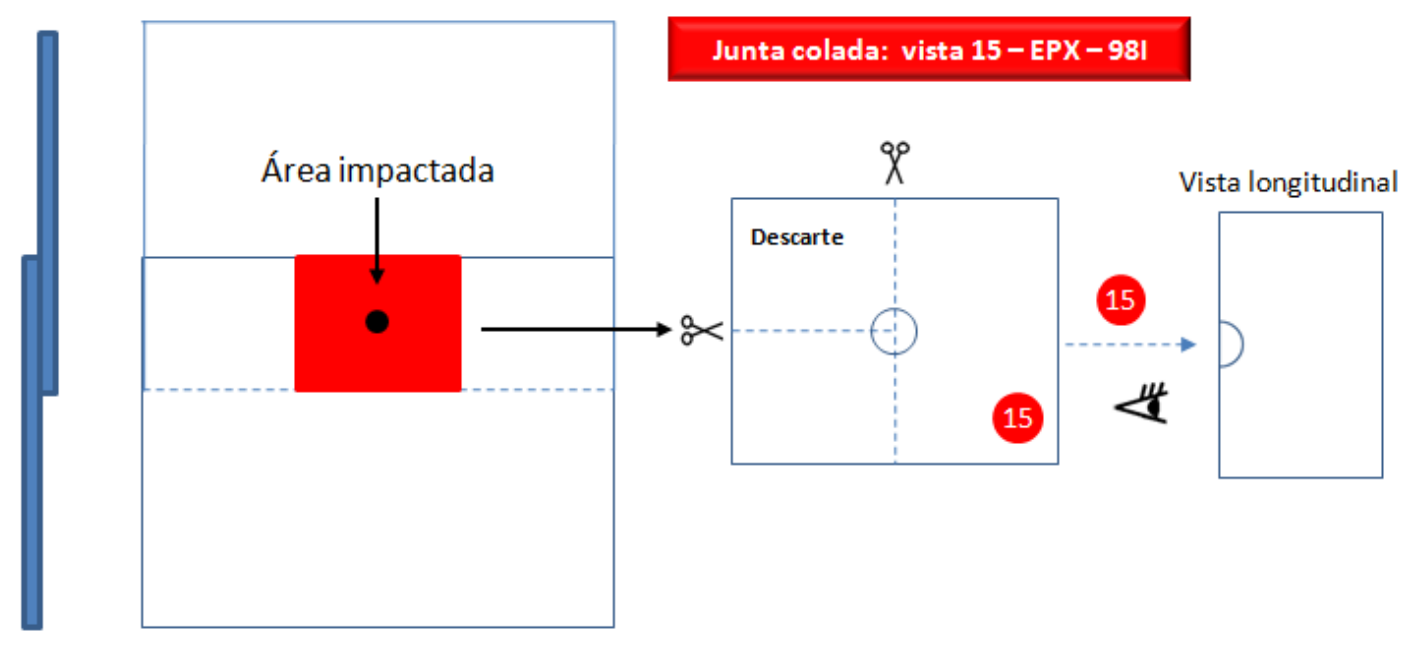

(a)

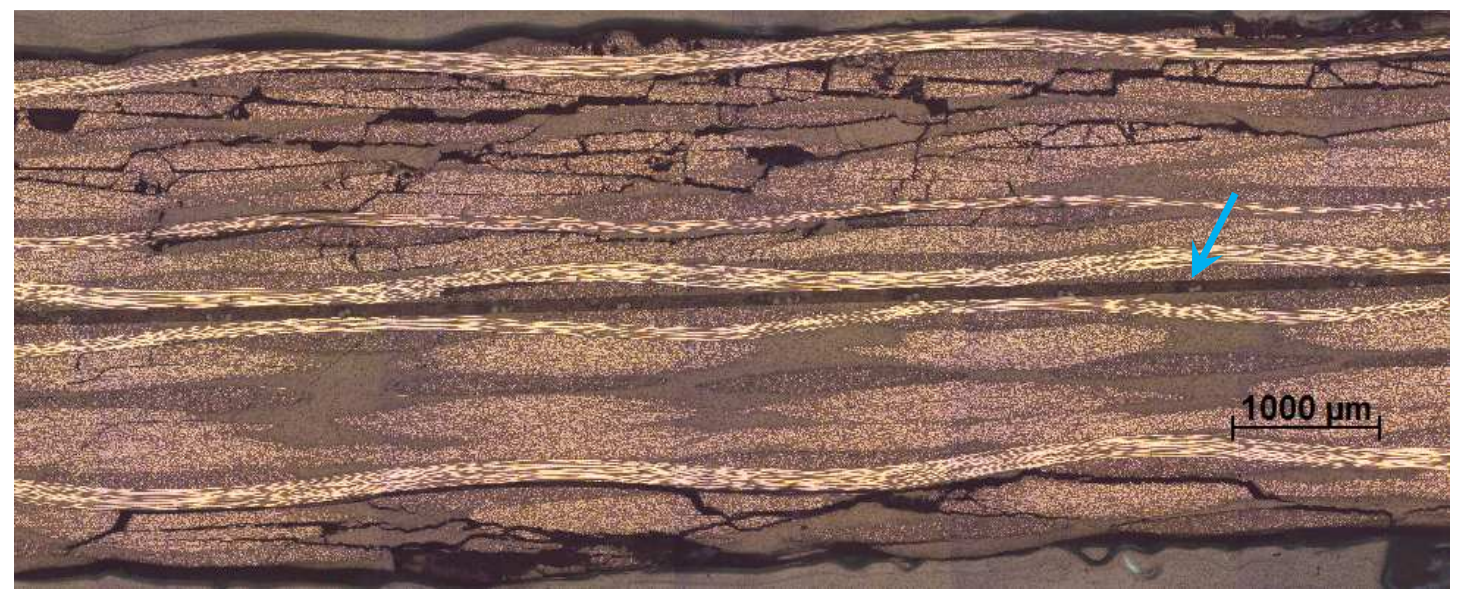

(b) 


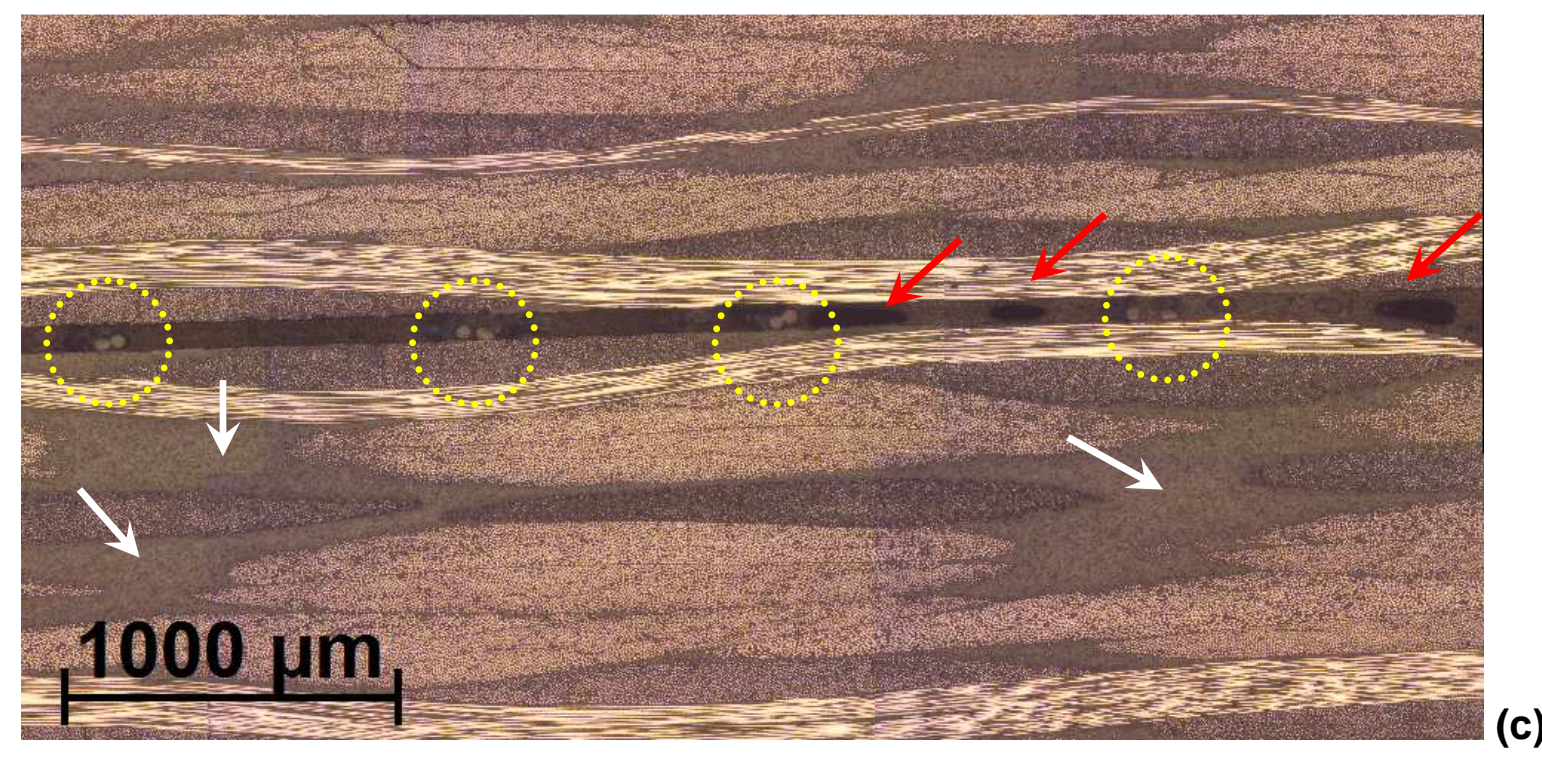

Figura 4.27 - (a) Esquema de retirada da amostra materialográfica codificada 15 - EPX - 98 I (b) Microfotografia da junta EPX-C na condição de somente impactada, com a face de impacto inferior, sendo o local de observação central, e direção de observação longitudinal à junta (a seta azul indica a linha de colagem); (c) Sinais da presença da rede polimérica filamentar para minimizar perda de adesivo durante a colagem da junta são destacados em círculos amarelos. Bolhas/vazios (indicados pelas setas vermelhas) na linha de colagem, assim como áreas ricas em resina (setas brancas) no laminado impactado (inferior) são identificados.

\subsubsection{Junta Simplesmente Impactada: Região Central, Vista Transversal}

A Figura 4.28a mostra esquematicamente a estratégia de retirada de uma amostra avaliada por microscopia óptica de luz refletida a partir de uma junta EPX-C na condição de simplesmente impactada, a qual se diferencia da imagem anterior somente pelo fato de que a vista do dano se dá numa direção deslocada de $90^{\circ}$ relativamente àquela antecedente.

Bolhas/vazios não são visualmente detectados na porção avaliada da linha de colagem (isto pode em alguma extensão estar associada à ausência de qualidade/magnitude de ampliação da foto e/ou da tela de imagem, e, portanto, não é uma observação conclusiva), chamando mais a atenção o padrão de trincas que se estabelece no aderente não-impactado, contiguamente à linha de colagem da junta de cisalhamento termorrígida. 


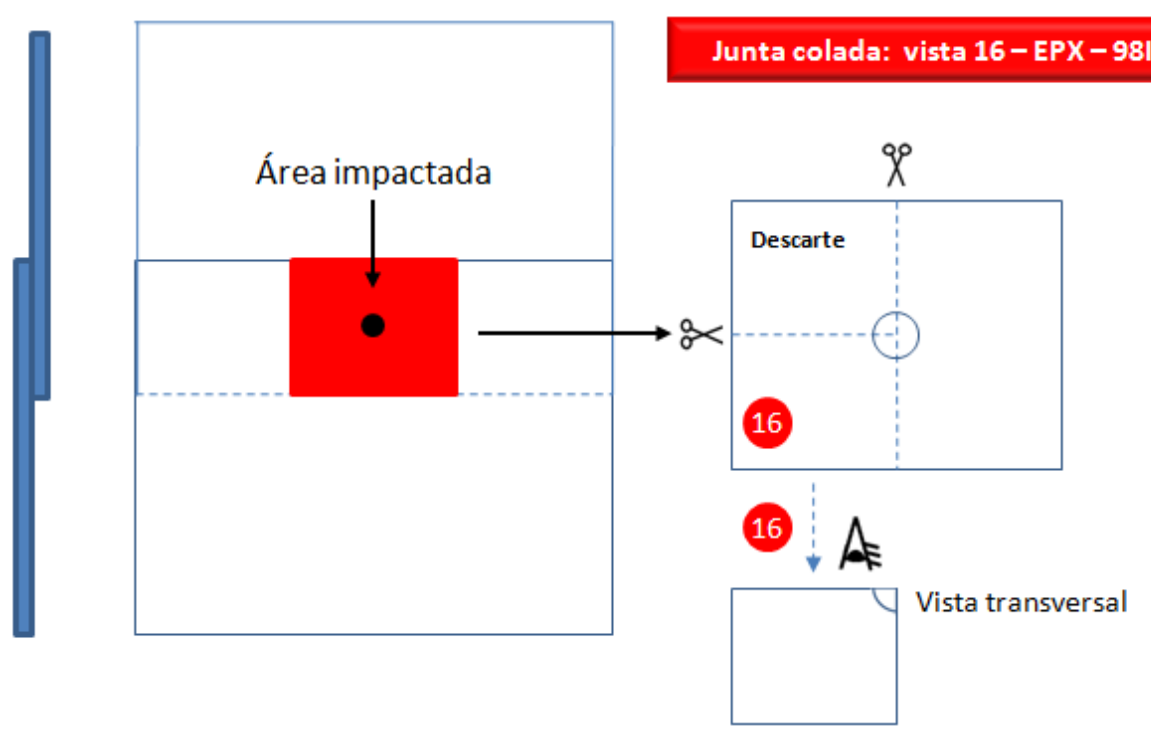

(a)

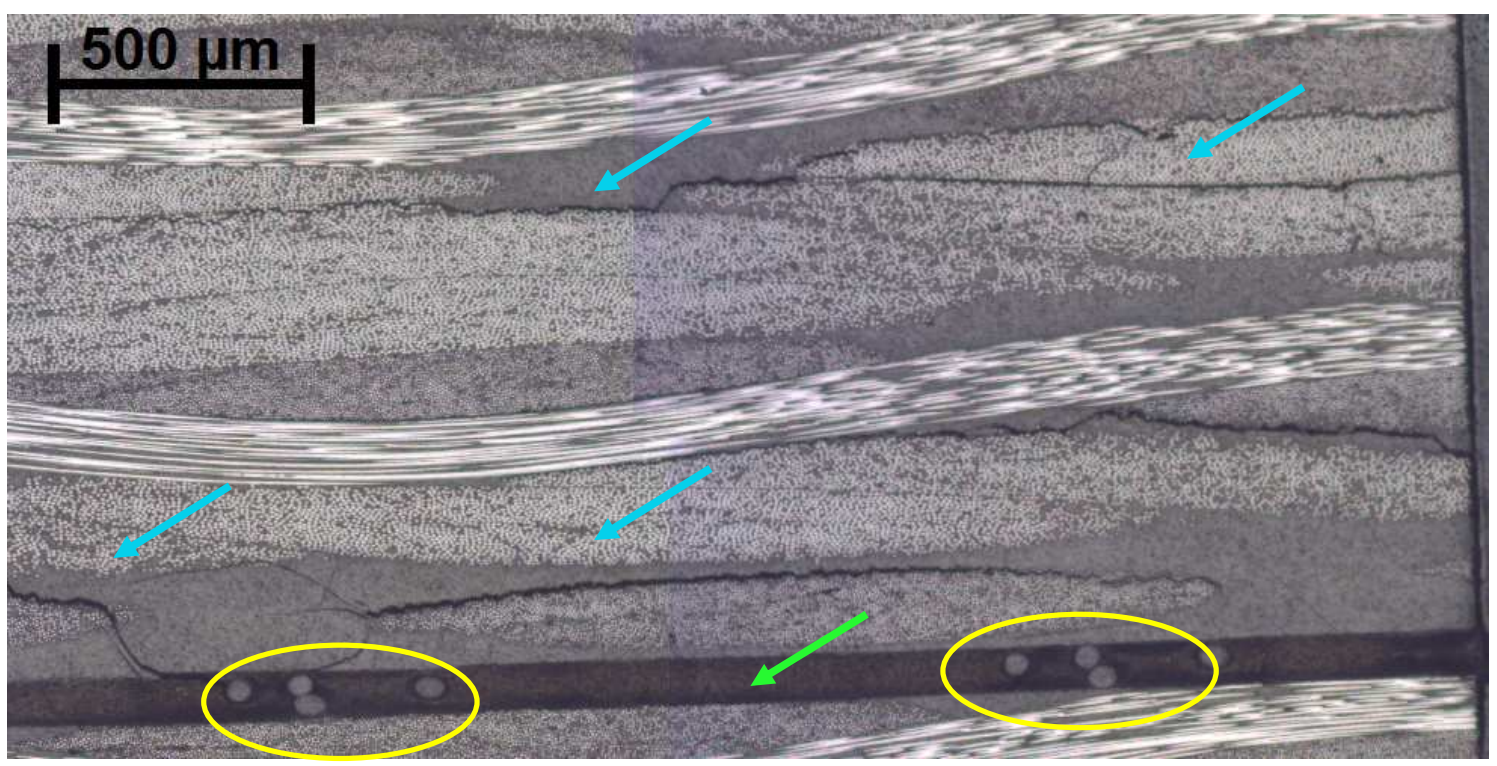

(b)

Figura 4.28 - (a) Esquema de retirada da amostra materialográfica codificada 16 - EPX 98I; (b) Microfotografia da junta EPX-C na condição de somente impactada, com a face de impacto inferior, sendo o local de observação central, e direção de observação transversal à junta. Sinais da presença da rede polimérica filamentar para minimizar perda de adesivo líquido durante a colagem da junta são destacados em elipses amarelas. A seta verde indica a linha de colagem, enquanto setas azuis apontam para numerosos e longos trincamentos no aderente não-impactado (superior), na forma de delaminações e trincas intralaminares transversais. 


\subsubsection{Junta Impactada e Envelhecida Higrotermicamente: Região Central, Vista Longitudinal}

A Figura 4.29a mostra esquematicamente a estratégia de retirada de uma amostra avaliada por microscopia óptica de luz refletida a partir de uma junta EPX-C na condição de impactada e subseqüentemente exposta a condicionamento higrotérmico.

Chama a atenção neste caso não somente os numerosos e longos trincamentos no aderente não-impactado (superior), na forma de delaminações e trincas intralaminares transversais, os quais se encontram muito mais concentrados na porção do laminado próxima à superfície, mas também e tão importante quanto, a questão da abertura destes trincamentos, muito mais pronunciados que os verificados nas juntas EPX-C simplesmente impactadas (Figs 4.27 e 4.28). Pode-se postular que o efeito do condicionamento higrotérmico subseqüentemente aplicado à junta no caso presentemente avaliado tenha sido responsável por este efeito, o qual certamente leva a uma degradação mais acentuada da integridade estrutural da junta, com reflexos mais altamente negativos nas propriedades mecânicas residuais da mesma frente à junta simplesmente impactada.

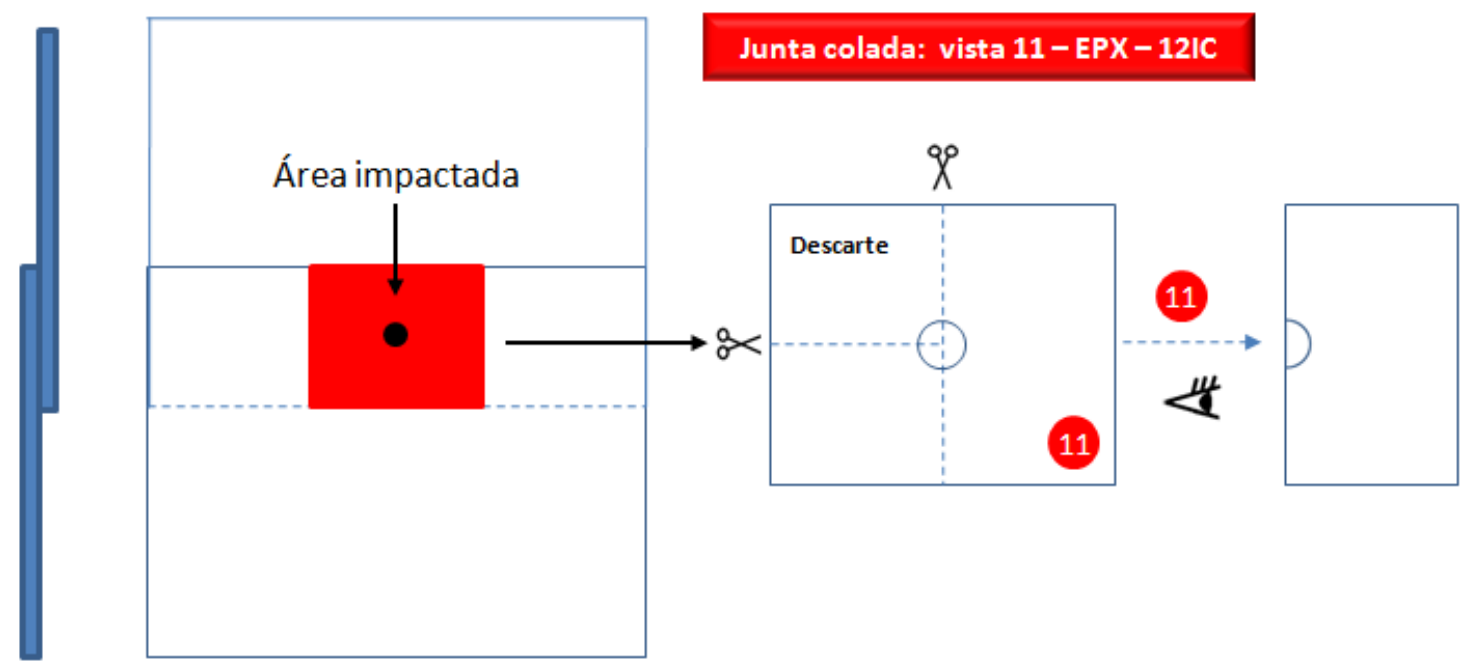

(a) 


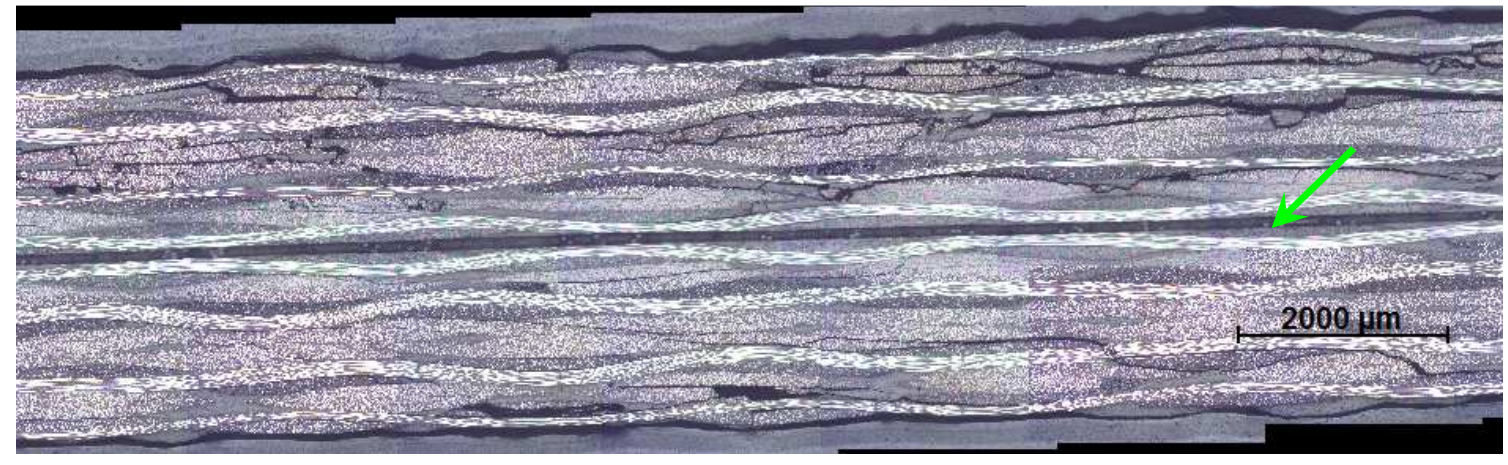

(b)

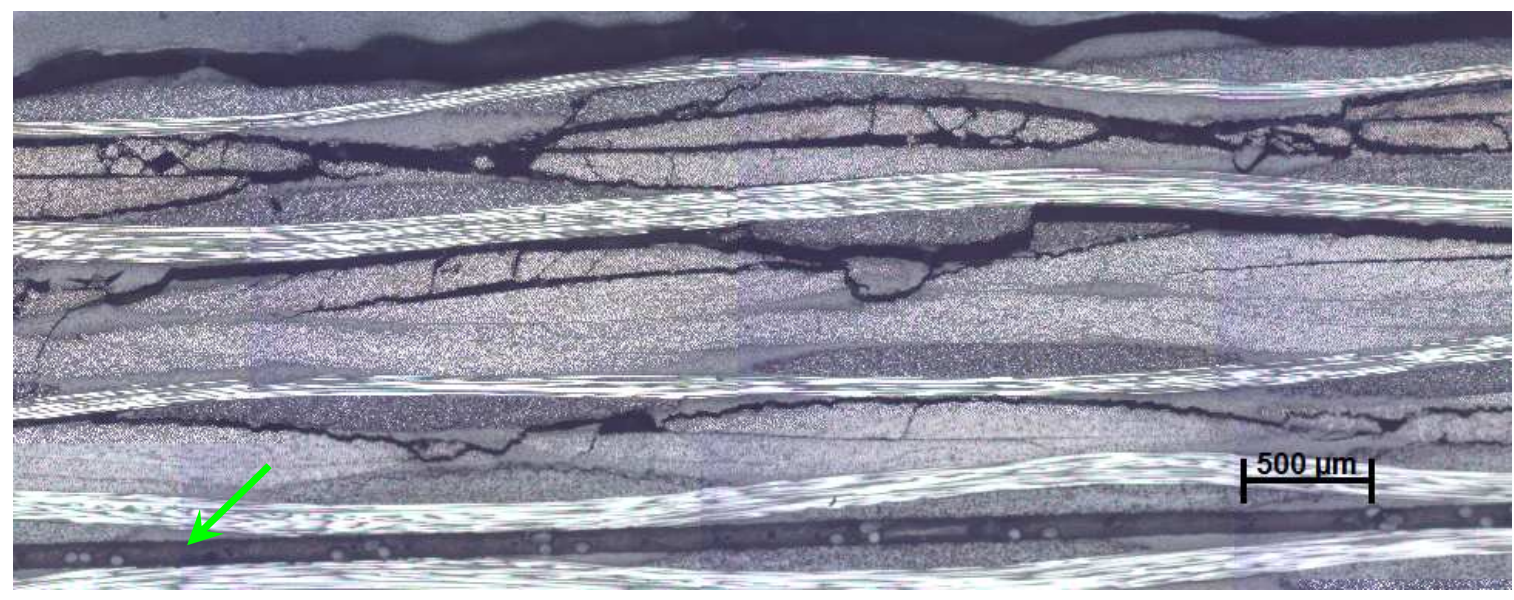

(c)

Figura 4.29 - (a) Esquema de retirada da amostra materialográfica codificada 11 - EPX 12IC; (b) Microfotografia da junta EPX-C na condição de impactada+condicionada, com a face de impacto inferior, sendo o local de observação central, e direção de observação longitudinal à junta. (c) A seta verde indica a linha de colagem.

\subsubsection{Junta Impactada e Envelhecida Higrotermicamente: Região Central, Vista Transversal}

A Figura 4.30a mostra esquematicamente a estratégia de retirada de uma amostra avaliada por microscopia óptica de luz refletida a partir de uma junta EPX-C na condição de impactada e subseqüentemente envelhecida pela aplicação simultânea de calor e umidade, a qual se diferencia da imagem anterior somente pelo fato de que a vista do dano se dá numa direção deslocada de $90^{\circ}$ relativamente à figura predecessora.

A presença de inúmeros vazios/bolhas na linha de colagem é notável, em especial próximo aos filamentos poliméricos de restrição de escorrimento de adesivo durante a manufatura da junta. Conforme comentado relativamente à Figura 4.28, a 
eventual não detecção visual de defeitos de colagem pode estar associada à ausência de qualidade/magnitude de ampliação da foto e/ou da tela de imagem, e a Figura 4.30 pode ser considerada um exemplo típico da necessidade de cuidadoso preparo e documentação do espécime, principalmente empregando-se inspeção materialográfica por microscopia óptica de seções transversais/longitudinais de laminados sólidos compósitos fibrosos. Na área observada da Figura 4.30, o padrão de trincamento que se estabelece no aderente não-impactado (superior) é predominantemente por delaminação, enquanto que, no laminado impactado (inferior), ele é, via de regra, intralaminar transversal.

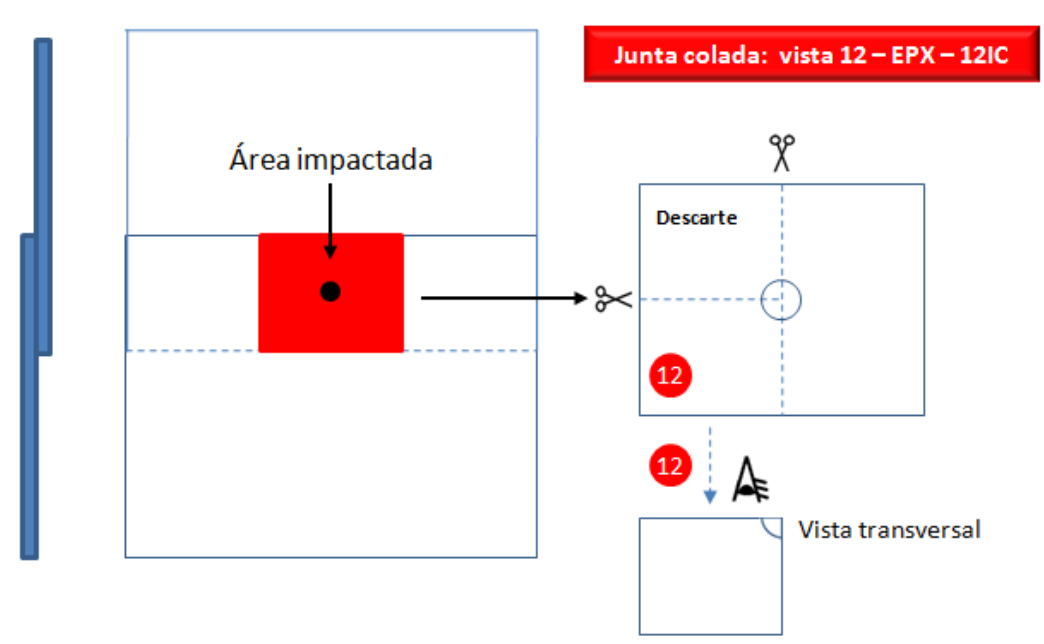

(a)

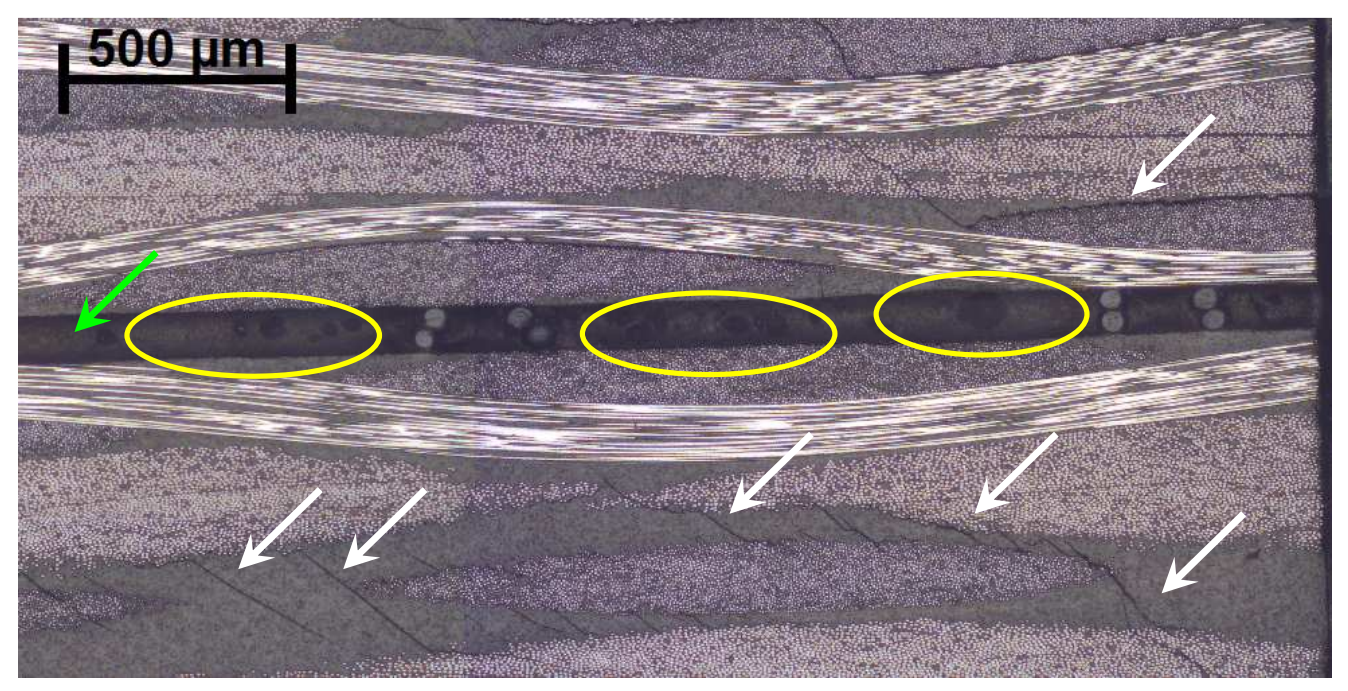

(b)

Figura 4.30 - (a) Esquema de retirada da amostra materialográfica codificada 12 - EPX 12IC; (b) Microfotografia da junta EPX-C na condição de impactada+condicionada, com a face de impacto inferior, sendo o local de observação central, e direção de observação transversal à junta. A seta verde indica a linha de colagem, enquanto as setas brancas apontam para os vários trincamentos identificados. Defeitos em profusão na linha de colagem (bolhas/vazios) são destacados por círculos e elipses amarelas. 
Embora o uso de técnicas de inspeção por não-destrutivos esteja entre os objetivos desse trabalho, na Figura 4.31 são ilustradas duas imagens obtidas por inspeção termográfica. Foi empregado nesta tarefa um sistema termográfico infravermelho da TWI ${ }^{\circledR}$ - Thermal Wave Imaging, modelo Echotherm 32 com pósprocessadores de imagens Echotherm e Mosaic, operado segundo a técnica de aquecimento por Pulso Rápido de Aquecimento (Flash), com duração de pulso de excitação óptica da ordem de micro-segundos.

Na Fig. 4.31a, tem-se a imagem para um CDP de PPS-C impactado e na Fig. 4.31b a imagem é de um CDP de EPX-C impactado, ambos com impacto único de 10J. Observa-se que para o EPX-C a área danificada (no centro) aparece maior que para o PPS-C.

No entanto, como mostrado nas figuras anteriores referentes aos cortes longitudinais e transversais para as amostras impactadas analisadas, não se observam extensos danos na região central para a amostra de PPS-C, mas pequenas micro-trincas espalhadas ao longo da região de soldagem, ou seja, a técnica termográfica aplicada neste caso não revelou a real condição de danos provocados pelo impacto único.

Para o EPX-C, como mostrado nas figuras anteriores referentes aos cortes longitudinais e transversais para as amostras impactadas, diferentemente do espécime de PPS-C, foram observados trincas e principalmente delaminações concentradas na área de impacto.

Portanto, quanto à técnica de inspeção aplicada, esta forneceu resultados qualitativos, ou seja, foi possível identificar a área impactada através da imagem termográfica, mas sem a possibilidade de quantificar ou identificar os danos causados pelo impacto único para as duas classes de juntas analisadas.
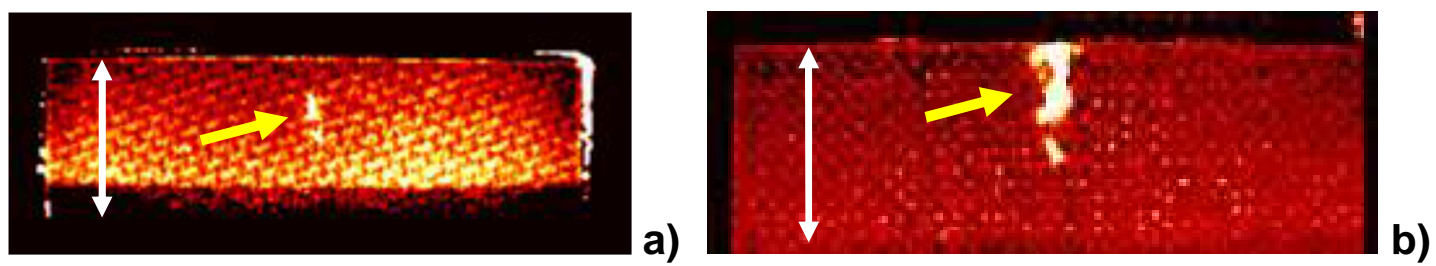

Figura 4.31 - Espécimes impactados e analisados por inspeção termográfica onde a) PPSC impactado e b) EPX-C impactado. A seta (amarela) indica o centro do espécime afetado pelo impacto e a dupla seta (em branco), ilustra a largura da área de junção 
Esta ultima observação quanto à tendência de os danos se concentrarem mais próximos da área de impacto nos espécimes EPX-C, em oposição aos espécimes concorrentes de PPS-C, em que os danos se distribuíram muito mais amplamente ao longo da área de sobreposição da junta termoplástica, poderia ser tentativamente explicada em termos tanto das características das matrizes poliméricas em questão (PPS mais dúctil e tenaz, que a EPX, a qual exibe tipicamente características de maior fragilidade), quanto da arquitetura da junta (a PPS-C contendo um inserto metálico dúctil entre os aderentes, enquanto a EPX-C possui um adesivo epoxídico de natureza quebradiça). Em sendo assim, a maior fragilidade estrutural da junta EPX-C frente à PPS-C possibilitaria a primeira a absorção da energia de impacto por intermédio de mecanismos de fratura (trincamento da matriz e ruptura das fibras, descolamento entre fibra e matriz, delaminações, etc...) altamente localizados na região de impacto, enquanto que a maior ductilidade/tenacidade estrutural da junta concorrente PPS-C propiciaria uma distribuição mais vasta, e, portanto, mais homogênea, de danos nos locais mais convenientes, quais seja, os de menor resistência ao dano, que se encontram mais pontualmente disseminados (ou altamente localizados) ao longo de toda a área de sobreposição da junta termoplástica.

Com base nas vistas das seções materialográficas transversal e longitudinal dos espécimes EPX-C submetidos a impacto único e impacto+condicionamento ambiental (calor e umidade simultâneos), proximamente à borda dos espécimes, e juntamente à região do impacto central impingido aos mesmos, concluiu-se também que:

$\checkmark$ Foram observadas regiões ricas em resina nos aderentes, assim como quantidades significativas de defeitos tipo bolhas/vazios na linha de colagem;

$\checkmark$ Em espécimes simplesmente impactados, assim como os espécimes impactados e subseqüentemente condicionados, observou-se que os danos causados pelo choque mecânico tenderam a se concentrar junto à área de impacto. 


\subsection{Análise microscópica da falha (MEV)}

\subsubsection{Juntas soldadas - PPS-C}

A Figura 4.32 mostra fibras de vidro pertencentes a uma junta soldada de laminados PPS-C na condição impactada + condicionada higrotermicamente $(I+C)$ e outra na condição virgem, após carregamento mecânico monotônico quase-estático em F4P. Nas figuras 4.32.a e 4.32.b, nota-se um efeito de desacoplamento das fibras relativamente ao polímero que originalmente o revestia. $O$ desacoplamento pode estar associado a permeação da umidade via efeito de capilaridade na interface FV-polímero, contribuindo para a substancial queda na resistência residual junta $(I+C)$ no teste de F4P (Figura 4.1).

No entanto, como observado para a CDP virgem (Fig. 4.32.c e Fig. 4.32.d) que também apresenta desacoplamento entre FV-polímero, o problema pode estar associado ao desempenho do agente de acoplagem requerido para melhorar a adesão interfacial FV-polímero, pois conforme aumenta à temperatura e tempo de processamento da matriz (como na soldagem), o agente de acoplagem pode perder a sua estabilidade térmica enfraquecendo a interface FV-polímero.

Contudo, as hipóteses aqui citadas requerem análises complementares para serem substanciadas. No entanto, é possível afirmar que o condicionamento higrotérmico foi deletério para a junta soldada.
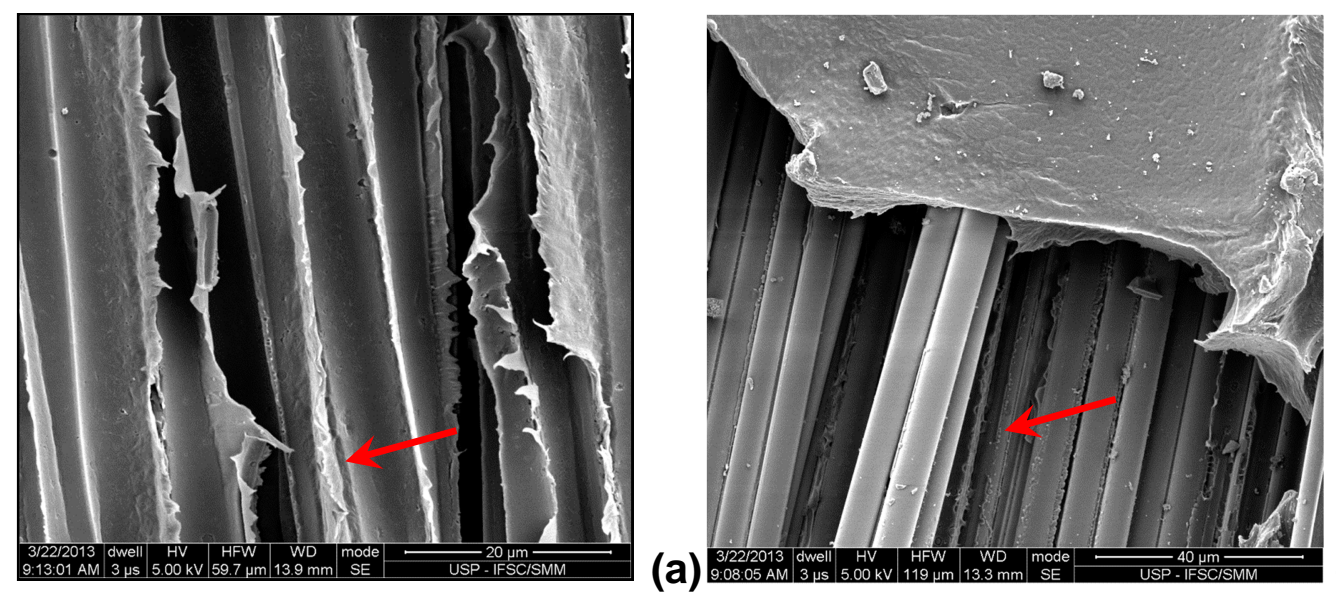

(b) 


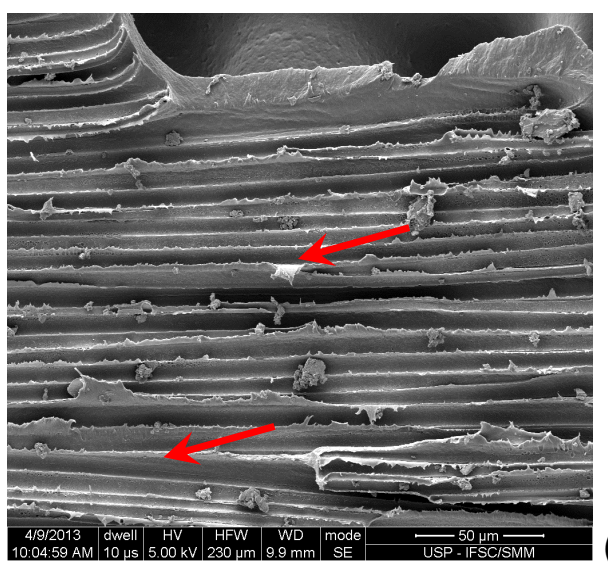

(c)

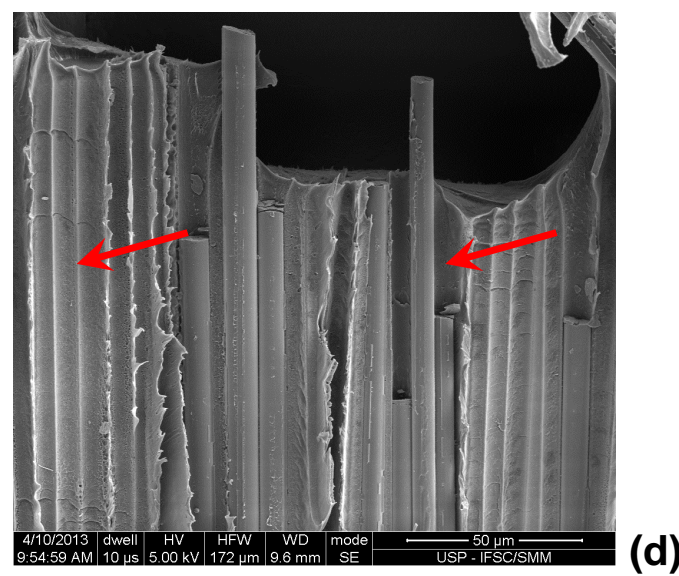

Figura 4.32 - $(a, b)$ Vista de fibras de vidro que sofreram completo efeito de desacoplamento da matriz de PPS na condição $(\mathrm{I}+\mathrm{C})$ onde as setas vermelhas apontam para fibras e conjuntos de fibras completamente descobertas quanto ao seu revestimento polimérico original, caracterizando uma típica falha adesiva; Para o CDP virgem em (c) espaços ocupados pelas fibras descoladas integralmente de seus sítios originais são também indicados por setas; (d) fibra exposta e sítio outrora ocupado por fibras.

A Figura 4.33 fornece pistas do prejuízo potencialmente elevado que a fraca interação interfacial entre as fases orgânica (polimérica) e metálica (ex., note os vãos de distanciamento entre as mesmas, indicados por setas vermelhas), devida à presença do inserto metálico permanente de aquecimento por efeito Joule, há de ter imposto ao desempenho mecânico final das juntas PPS-C.

Chama à atenção na Figura 4.33, a clara falta de molhabilidade das fibras da malha de aço pela matriz de PPS. Esta baixa adesão interfacial contribui para a baixa resistência mecânica da junta no ensaio de F4P para o laminado virgem.
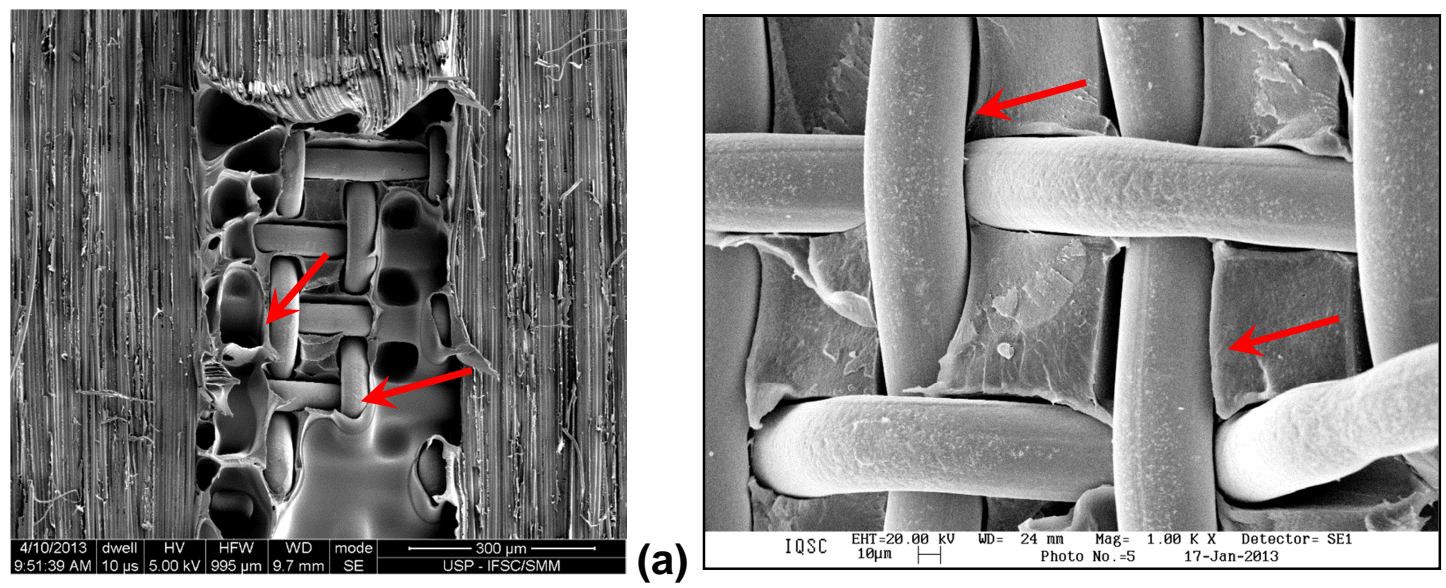

(b)

Figura 4.33 - $(a, b)$ Claros indicativos da falta de molhabilidade da malha de aço pelo polímero PPS. 
Dada a extrema facilidade com que a interface metal/polímero se separa (Fig. 4.33) - ou mesmo nem chegue a interagir, conclui-se indiretamente que a interface existente entre o filme de enriquecimento de PPS e a lâmina externa de PPS-V que reveste o núcleo de PPS-C do aderente seja também extremamente fraca, explicando desta forma os baixos valores atingidos de resistência residual desta classe de juntas termoplásticas unidas por fusão perante sua concorrente EPX-C, de matriz termorrígida e unida com resina epoxídica. Neste sentido, para o sistema de aderente empregado (híbrido PPS-C / PPS-V, sendo o revestimento de fibras de vidro requerido para fins de evitar o contato entre o elemento gerador de calor e as camadas de carbono durante o processo de soldagem devido ao chamado "vazamento de corrente", gerando perda de calor na área de solda, diminuindo assim a eficiência e a qualidade do processo do produto final - o núcleo de PPS-C do laminado base - o qual, a rigor é quem haveria de sustentar o carregamento mecânico), já era de se esperar tal comportamento e nível de desempenho, tendo em vista que o elo mais fraco é que define o comportamento do sistema global. Assim, a falha mecânica de baixo desempenho desta classe de junta resulta tanto da natureza intrinsecamente híbrida do sistema (destacando-se as fibras de classes distintas, a interface metal-polímero e a presença do inserto permanente, o qual é inexoravelmente uma descontinuidade geométrica e material de efeito deletério considerável), como de potenciais más práticas de processamento, por meio de seleção e/ou aplicação inadequada dos parâmetros de processo de soldagem.

A Figura 4.34a revela a elevada ductilidade dos filamentos que compõem a malha metálica, quando se observam claramente a fratura de alguns deles precedida por substancial estriç̧ão antes da falha por tração e notável deformação por contato interfilamentar (setas vermelhas).

A Figura 4.34b corrobora a baixa interação interfacial entre as fases orgânica e inorgânica acima mencionadas, assim como a tendência ao aprisionamento de ar (formando bolhas - setas amarelas) no espaço entre os laminados (ou aderentes) ocupado pela malha eletricamente condutora, à qual foram invariavelmente intercalados, em ambas as suas faces, um filme de PPS puro visando o enriquecimento local com o elemento polimérico adesivo. 


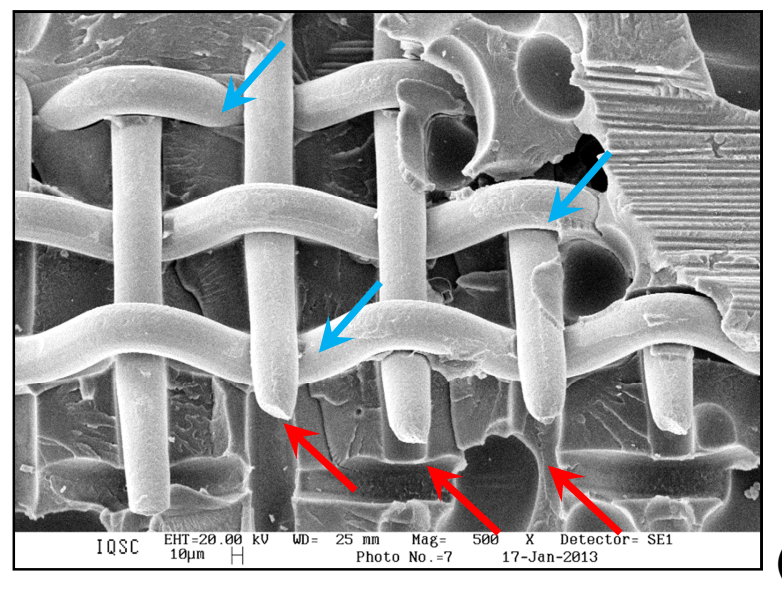

(a)

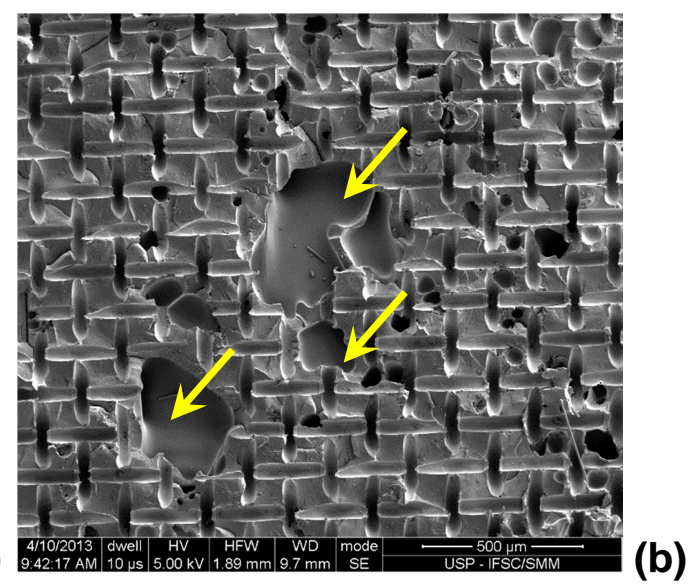

Figura 4.34 - (a) Sinalização de extrema ductilidade (setas vermelhas) (e, muito provavelmente, reduzida resistência mecânica) da malha metálica de aquecimento para soldagem localizada entre os laminados termoplásticos fibrosos (aderentes) da junta PPS-C; Comprovação visual adicional da baixa interação metal/polímero (setas azuis) e (c) massiva presença de vazios/bolhas gerados na soldagem pelo aprisionamento de grande quantidade de ar entre os aderentes (setas amarelas).

A presença destas descontinuidades é detrimental, além de todos aqueles fatores anteriormente discutidos no que concerne à junta PPS-C soldada por resistência elétrica, não só em função de seu poder de concentração de tensão, mas também por reduzir significativamente a extensão em termos de área de contato superficial da já comprovadamente fraca interface metal/polímero.

A partir da análise das superfícies de fratura de juntas PPS-C via microscopia eletrônica de varredura concluiu-se que:

$\checkmark$ Baixa interação entre 0 filme de polímero PPS adicionado para enriquecimento da região da junta por soldagem e a camada externa de PPS + fibra de vidro que reveste o laminado interno de PPS + fibra de carbono;

$\checkmark$ A interação interfacial entre o polímero PPS e a malha de aço utilizada para gerar o calor para a soldagem mostrou-se de baixíssima energia, se existente, fazendo com que a resistência da junta soldada fosse baseada na fraca ligação física existente entre a malha metálica e o polímero, em detrimento da fusão polimérica causando difusão intermolecular entre os dois laminados que exibe, teoricamente, uma integridade e resistência superiores a da interface orgânica/inorgânica; 


\subsubsection{Juntas coladas - EPX-C}

A Figura 4.35 corresponde a um espécime EPX-C virgem onde se pode observar a presença de cúspides na matriz termorrígida nos espaços existentes entre as fibras de carbono, ou entre as posições ocupadas pelas mesmas anteriormente à fratura, durante o ensaio de resistência residual em F4P. Este tipo de morfologia de fratura predomina sob condições de carregamento por cisalhamento de sistemas compósitos fibrosos de matriz polimérica frágil, tal como o caso das termorrígidas (CÂNDIDO et al., 2014) e (TARPANI et al., 2006).

As imagens abaixo não permitem concluir cabalmente a respeito do nível de interação entre a matriz resinosa e as fibras de reforço, que, no caso do sistema EPX-C, deve ser de alta energia (i.e., interação forte), visto que são identificados tanto o descolamento de fibras (falha adesiva de relativamente baixa energia - setas vermelhas) quanto a fratura da matriz e de algumas fibras (falhas coesivas de relativamente alta energia - setas amarelas).
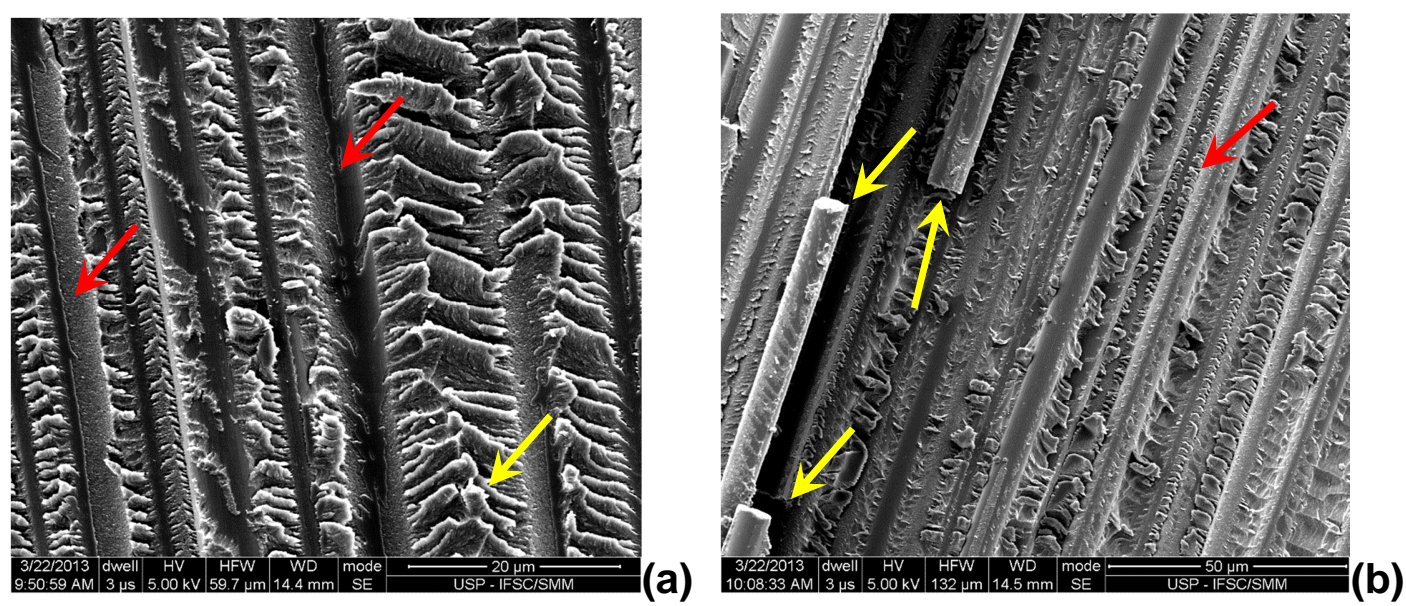

Figura 4.35 - (a,b) Fotomicrofratografias obtidas por microscópio eletrônico de varredura da superfície de ruptura de corpo de prova de junta EPX-C virgem pós-carregamento em F4P. 

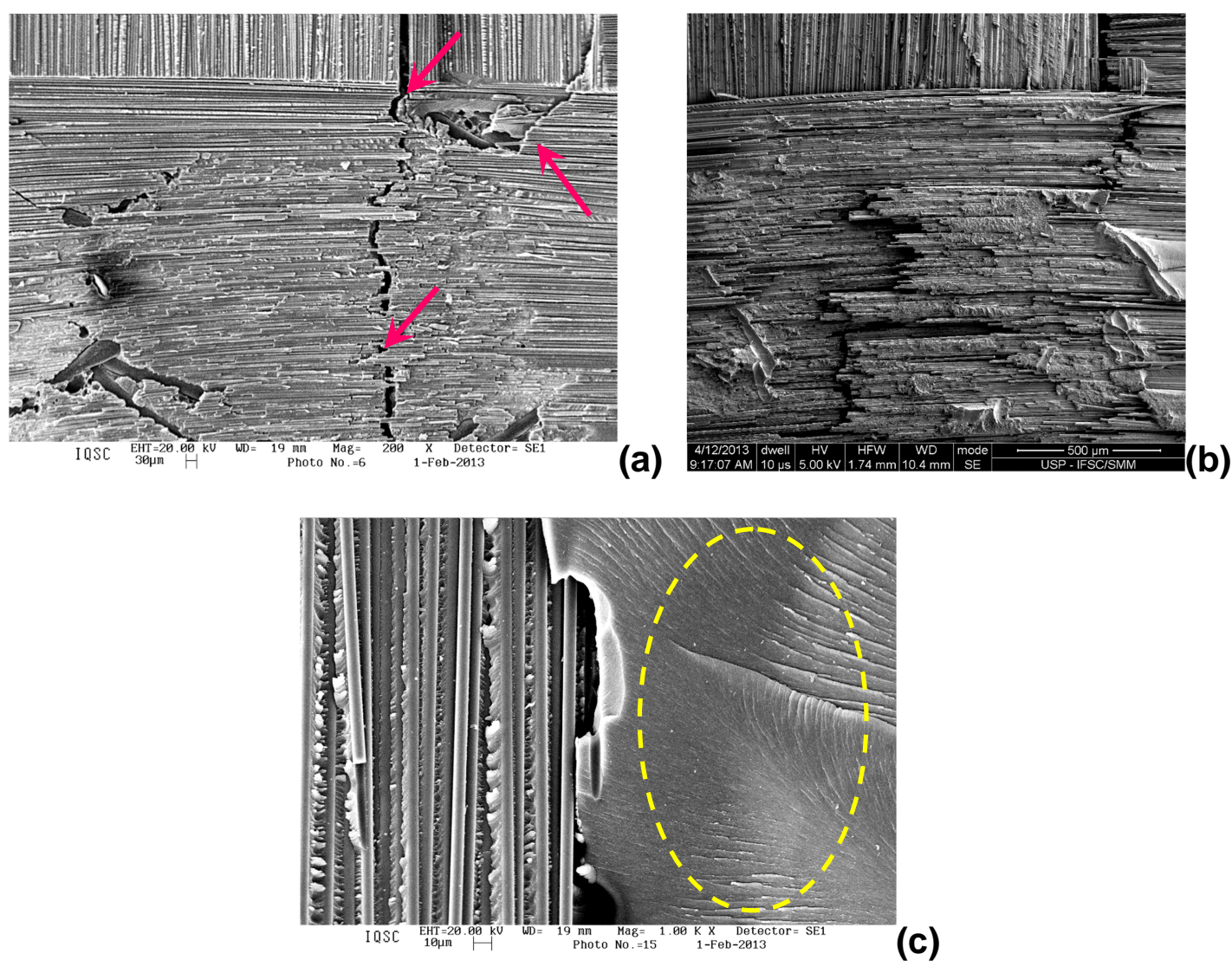

Figura 4.36 - (a-c) Fotomicrofratografias de varredura eletrônica de espécime previamente impactado, subseqüentemente condicionado, e finalmente fraturado em F4P.

A Figura 4.36 fornece imagens das superfícies de fratura em F4P de espécime previamente submetido a impacto e condicionamento ambiental. $\mathrm{Na}$ Figura 4.36a observa-se um extensivo trincamento ramificado (setado) causado pela ação do impacto único, enquanto que na Figura $4.36 \mathrm{~b}$ visualiza-se a face de uma delaminação gerada por impacto, porém sem quaisquer trincamentos presentes na região. É possível observar na Figura 4.36c aspectos fractográficos denominados modelos de pluma (CÂNDIDO et al., 2014) (elipse tracejada), indicando que a fratura ocorreu de modo coesivo próximo da região interfacial fibra/resina.

A Figura 4.37 ilustra as imagens de corpo de prova simplesmente fadigado em compressão em que se observam fibras rompidas e uma boa adesão entre as fases fibra e matriz. Nota-se claramente uma superfície de fratura particularmente irregular quando comparada aos espécimes de EPX-C não submetidos à fadiga em compressão. Essa característica observada pode ser devido a deformação plástica da resina epóxi (tenacificada) sob fadiga mecânica, uma vez que sob compressão, o reforço (fibras) não é efetivo quanto em carregamentos em tração. 
A Figura 4.38 mostra imagens da superfície de fratura de espécime de junta adesivada EPX-C submetida a impacto prévio e subseqüente fadiga compressiva para idêntico número de ciclos, tensão máxima de compressão e razão de cargas que o caso anterior (Fig. 4.37). Observam-se trincas causadas pelo impacto único de $10 \mathrm{~J}$ (setas amarelas) e uma vista da superfície irregular de fratura, está última nuance tal como também verificada na figura anterior da junta simplesmente fadigada em compressão (setas verdes).

A Figura 4.39 corresponde a uma junta EPX-C na condição prévia de impactada + condicionada ambientalmente + fadigada em compressão, logo após o derradeiro ensaio de F4P para determinação da sua resistência residual (i.e., tolerância a danos). Notam-se enormes vazios (Figs. 4.39a-c) criados certamente na operação de união por adesivagem dos aderentes, assim como uma estrutura alveolar na matriz e no adesivo epoxídicos termorrígidos (Figs. 4.39d-e), a qual possivelmente foi gerada durante $\mathrm{o}$ envelhecimento higrotérmico aplicado à junta subseqüentemente à imposição de um impacto com energia de $10 \mathrm{~J}$, pois tal característica alveolar não foi observada nos demais espécimes não submetidos as condições higrotérmicas. Nota-se também nas Figuras 4.39a-d novamente a presença da rede trançada filamentar polimérica empregada para limitar 0 escorrimento e perda de adesivo na interface entre os dois laminados EPX-C durante o processo de união. Esta rede filamentar deve contribuir para a geração de vazios na interface entre os aderentes sobrepostos, cooperando desta forma, além da sua própria presença física, para o enfraquecimento da junta.
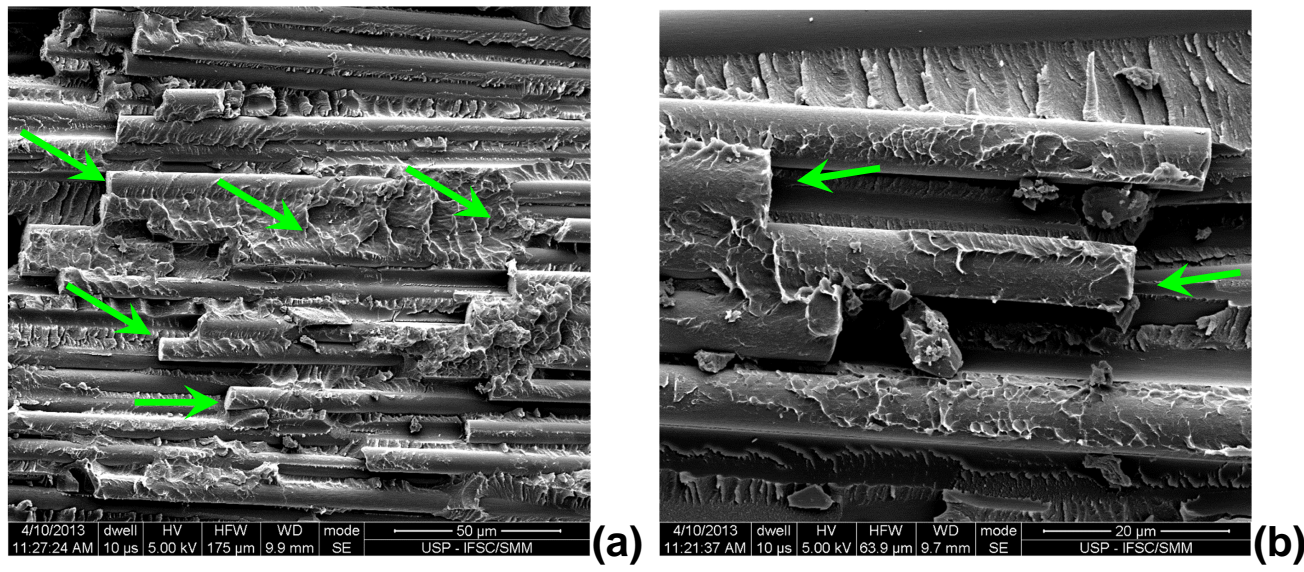

Figura 4.37 - $(a, b)$ Fotomicrofratografias de varredura eletrônica de espécime simplesmente fadigado em compressão em condições de amplitude constante de tensão. 


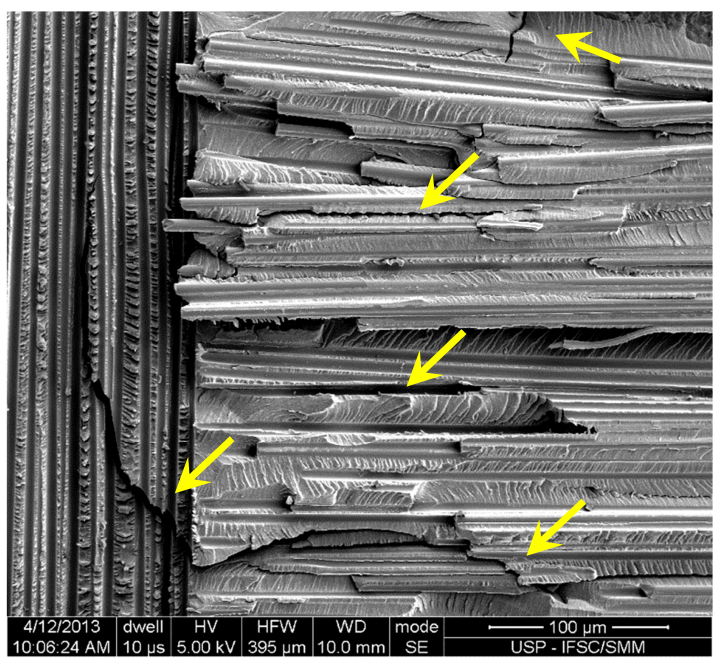

(a)

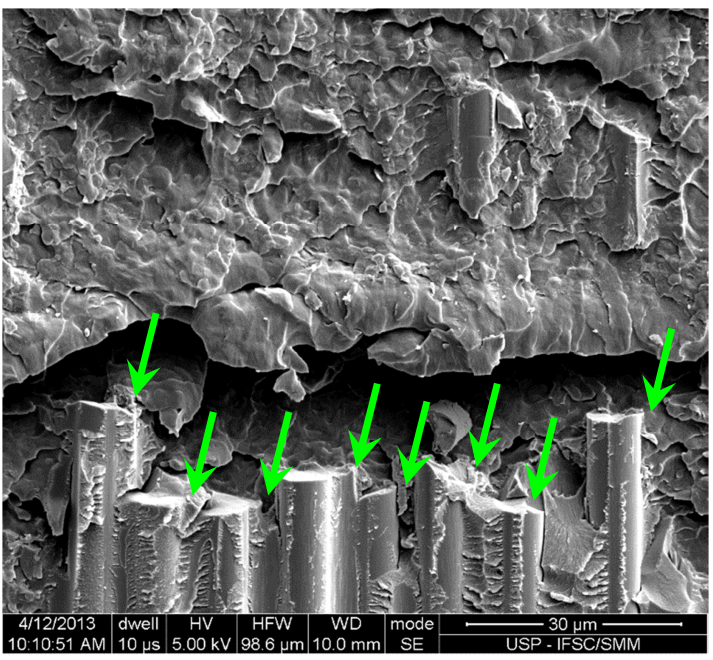

(b)

Figura 4.38 - (a) Fotomicrofratografia de varredura eletrônica de espécime impactado e fadigado destacando-se os danos decorrentes do carregamento dinâmico; (b) Destacandose danos oriundos do carregamento cíclico compressivo.
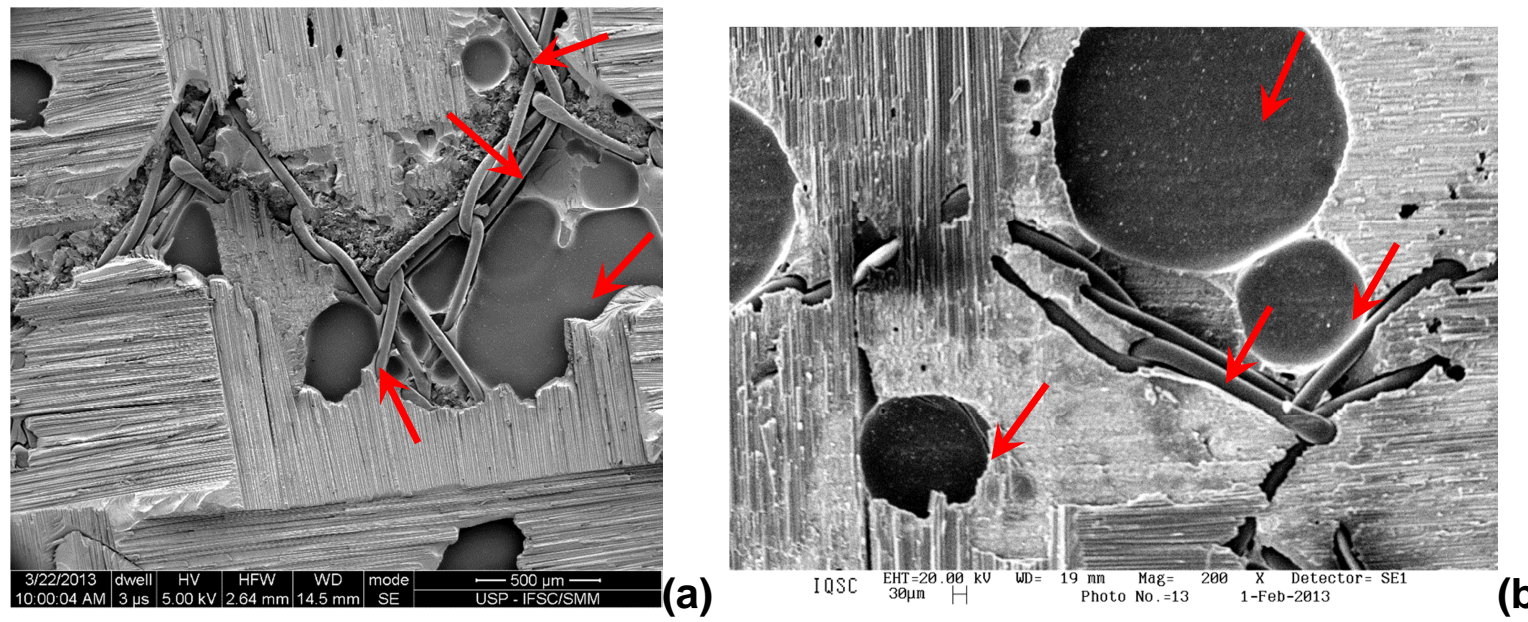

(b)
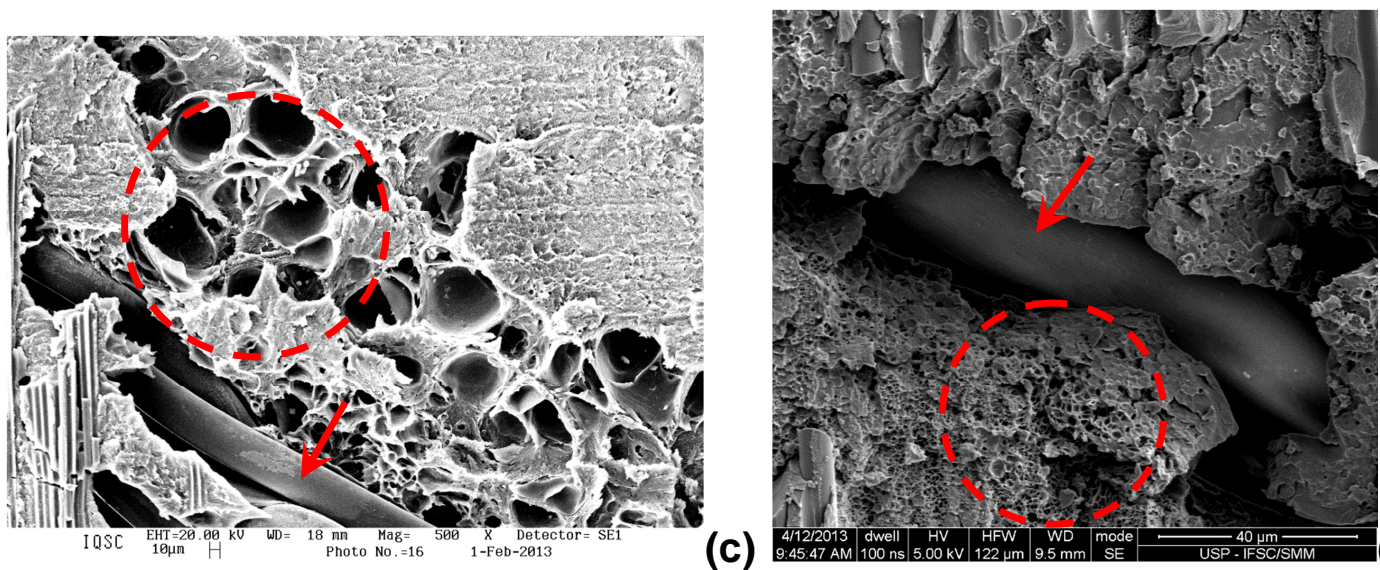

(d) 


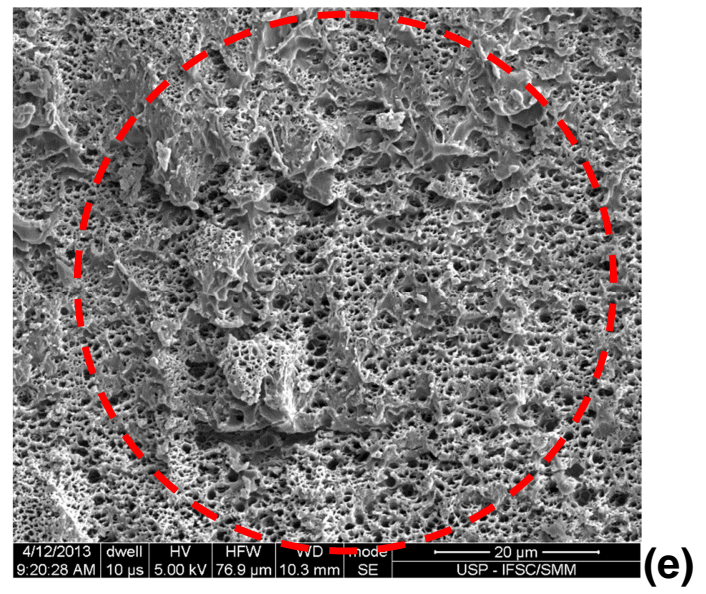

Figura 4.39 - (a-e) Junta EPX-C impactada, condicionada ambientalmente, fadigada em compressão e finalmente fraturada em $\mathrm{F} 4 \mathrm{P}$, em que se verifica a presença intencional de uma rede trançada filamentar polimérica, dos conseqüentes defeitos de manufatura do tipobolha/vazio na interface colada, além de danos de aspecto alveolar impostos ao adesivo epoxídico possivelmente pelo envelhecimento ambiental aplicado à junta termorrígida.
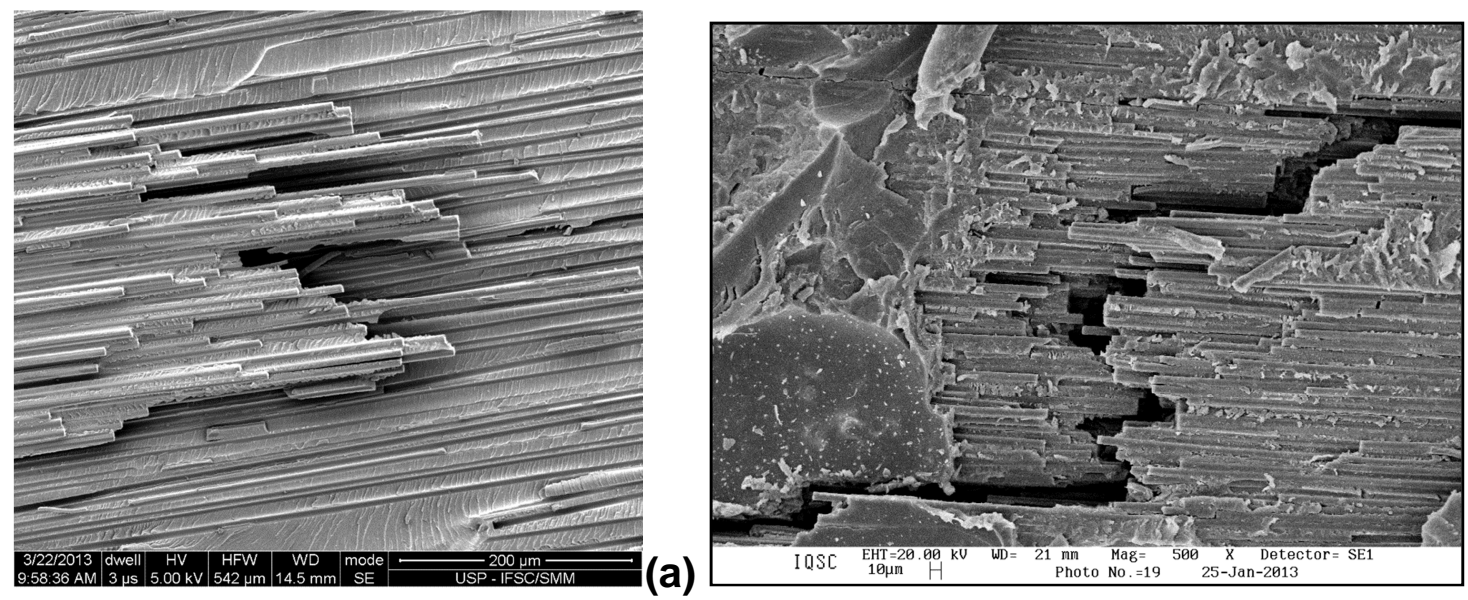

Figura 4.40 - $(a, b)$ Aspectos de fratura por F4P observados na interface entre os dois laminados EPX-C de uma junta sobreposta, em que se verificam regiões de boa qualidade do produto, visto que, mesmo sob a ação prévia de impacto, condicionamento ambiental e fadiga compressiva, uma muito boa adesão ainda permanece entre fases matriz e de reforço, tal como desejável para aderentes da classe EPX-C.

A Figura 4.40, por outro lado, exibe regiões que refletem alta qualidade (mesmo que local) do produto final, em que as fibras de carbono estão muito bem aderidas à matriz epoxídica (tal como se preconiza para este sistema compósito em face dos seus mecanismos prioritários de tenacificação / fortalecimento com base, por exemplo, em ancoramento de trincas na matriz pelas fibras de reforço), observandose apenas fratura da matriz termorrígida e ruptura das fibras de reforço (i.e., mecanismos de natureza coesiva) durante o ensaio F4P da junta submetida a 
diversos mecanismos de danificação prévia, seja por impacto, envelhecimento higrotérmico e mesmo fadiga compressiva.

A inspeção das superfícies de fratura de juntas EPX-C via microscopia eletrônica de varredura, possibilitou inferir, portanto:

$\checkmark$ A presença de vazios na área de colagem, principalmente nos espaços do entrelaçamento da malha polimérica;

$\checkmark$ Regiões ricas em resina localizadas no entrelaçamento entre as fibras de carbono;

$\checkmark$ Boa interação entre fibra e resina, mas fraca interação entre a resina e a malha polimérica;

$\checkmark$ Presença de cúspides na matriz nos espaçamentos entre fibras evidenciando cisalhamento na região da fratura;

$\checkmark$ Alteração da "textura" da matriz na superfície de fratura para os espécimes submetidos à fadiga anteriormente a F4P;

$\checkmark$ Possível degradação da matriz polimérica para os corpos de prova condicionados (submetidos à alta temperatura e níveis de umidade).

\subsection{Ensaios de ILSS}

O ensaio de ILSS foi aplicado nas amostras retiradas da área de soldagem e colagem dos espécimes conforme ilustrado na Figura 3.8 (Capítulo 3). Este ensaio foi utilizado para a análise da qualidade dos processos de uniões aplicados e também para avaliação quanto à extensão dos danos dentro da área de soldagem e colagem, causados pelo impacto único de $10 \mathrm{~J}$.

Foram selecionados para este tipo de ensaio apenas os espécimes nas condições "virgem" (V) e "impactado" (I).

Para o PPS-C foi utilizado neste ensaio 3 espécimes do tipo "virgem" e apenas um CDP do tipo "impactado". Para os espécimes do tipo "virgem", a Tabela A.5 (em Apêndices) mostra a tensão máxima obtida para cada amostra de 1 a 9 , a média e 0 
desvio padrão, lembrando que a média foi obtida para cada posição, ou seja, somando-se separadamente as tensões máximas alcançadas para as amostras 1,2, $3 \ldots$ até a amostra 9.

A Figura 4.41 representa o gráfico obtido de tensão média para cada amostra e sua respectiva posição a partir dos valores de tensão da Tabela A.5 (em Apêndices).

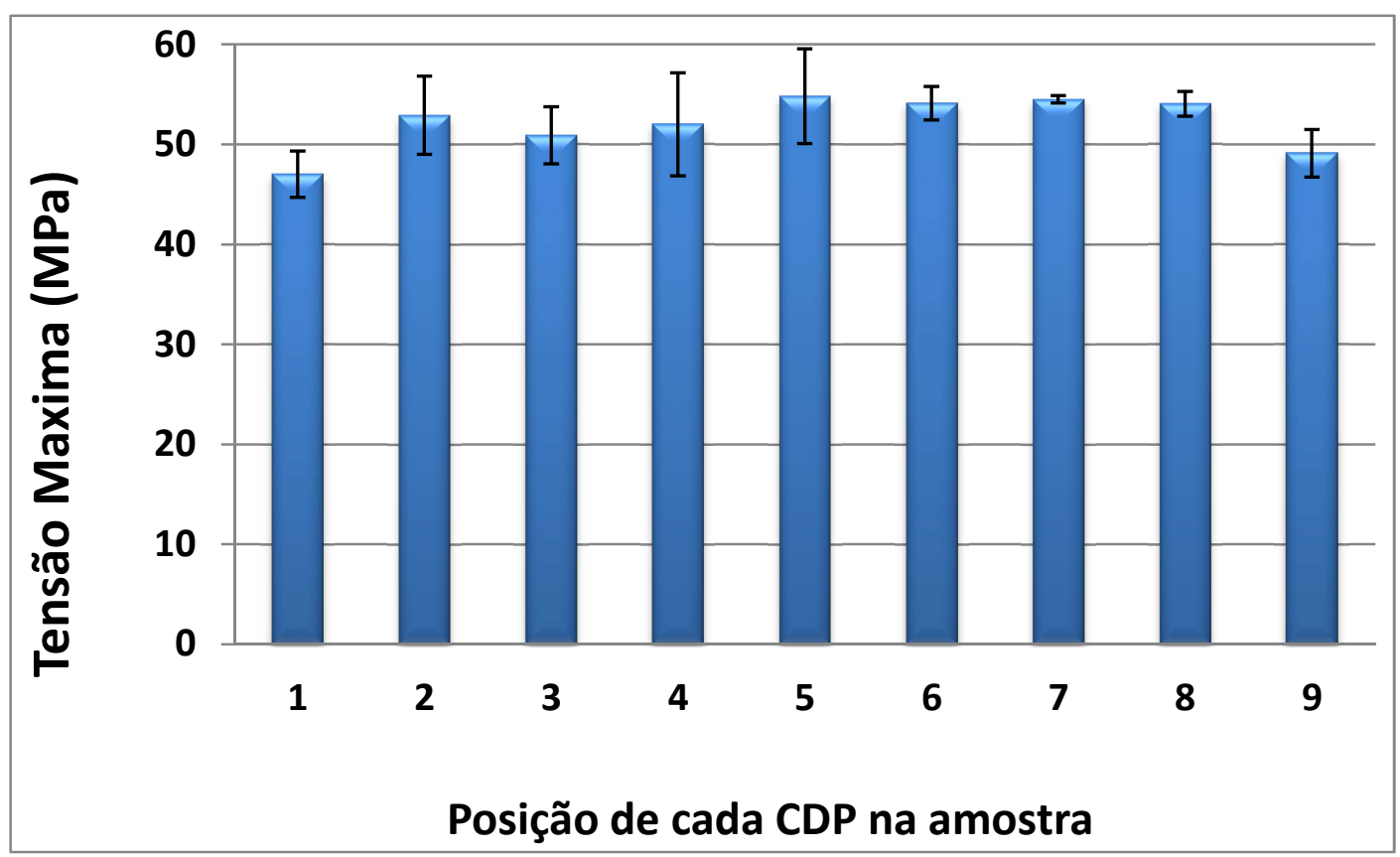

Figura 4.41 - Representa o gráfico obtido da média das tensões máximas para cada posição da amostra retirada da área de soldagem da junta de PPS-C virgem.

Para as amostras obtidas do espécime tipo "impactado", a Tabela A.6 (em Apêndices) mostra os valores adquiridos de tensão máxima para cada posição da amostra retirada da área de soldagem do espécime "impactado". Com esses valores foi gerado o gráfico da tensão máxima obtida e mostrado na Figura 4.42. Lembrando que tanto a Tabela A.6 como o gráfico da Figura 4.42 não apresentam média de valores, uma vez que apenas um espécime impactado foi seccionado na área de soldagem para gerar as amostras de 1 a 9. 


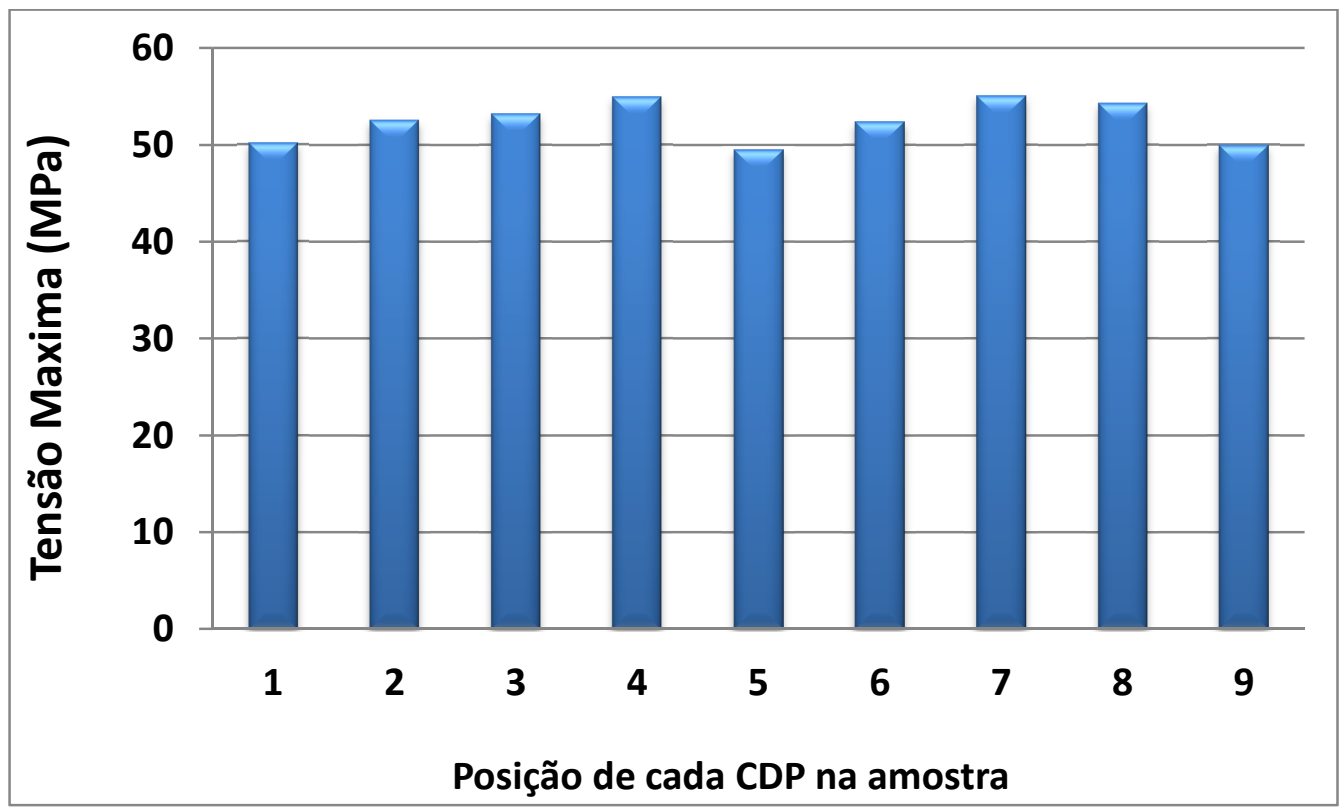

Figura 4.42 - Gráfico da tensão máxima para cada posição da amostra da área de soldagem da junta de PPS-C impactada.

Com base nas tabelas e gráficos obtidos para o ensaio de ILSS para as amostras soldadas descritas aqui, pode-se observar que:

$\checkmark$ As amostras 1 e 9 obtidas dos espécimes do tipo "virgem" (PPS-C) apresentaram resistência em média 10\% menor que as amostras adjacentes, ou seja, amostras 2 e 8 . Esse resultado evidencia que o processo de soldagem por resistência aplicado a esses espécimes gerou uma superfície de soldagem não-uniforme (com presença de muitos vazios, como verificado na análise estereoscópica) nas áreas próximas as bordas, onde havia os conectores de entrada e saída de corrente, contribuindo para a menor resistência destas amostras retiradas próximas as bordas.

Na Fig. 4.41, observa-se uma tendência na queda de propriedades quando se desloca do centro para as bordas das juntas sobrepostas simples de cisalhamento, devido à maior taxa de resfriamento do sistema na superfície livre da junta, levando a problemas de adesão e microestrutura (cristalinidade) naquela região.

$\checkmark$ A amostra 5 obtida do espécime 47 (I) "impactado" (Figura 4.42) alcançou resistência 6,5 \% menor do que as amostras adjacentes 4 e 6 . Esse resultado sugere que o impacto único de $10 \mathrm{~J}$ não ocasionou extensos danos na área de soldagem. 
Para os espécimes colados de EPX-C, foram utilizados CDPs com os mesmos tipos de condições dos utilizados para os soldados (PPS-C), ou seja, foram utilizados neste ensaio 3 espécimes do tipo "virgem" e apenas um espécime do tipo "impactado". Para os espécimes do tipo "virgem", a Tabela A.7 (em Apêndices) mostra a tensão máxima obtida para cada amostra de 1 a 9 , a média e o desvio padrão, enfatizando que a média foi obtida para cada posição, ou seja, somando-se separadamente as tensões máximas alcançadas para as amostras $1,2,3 \ldots$ até a amostra 9.

A Figura 4.43 representa o gráfico obtido de tensão média para cada amostra e sua respectiva posição a partir dos valores de tensão da Tabela A.7 (em Apêndices).

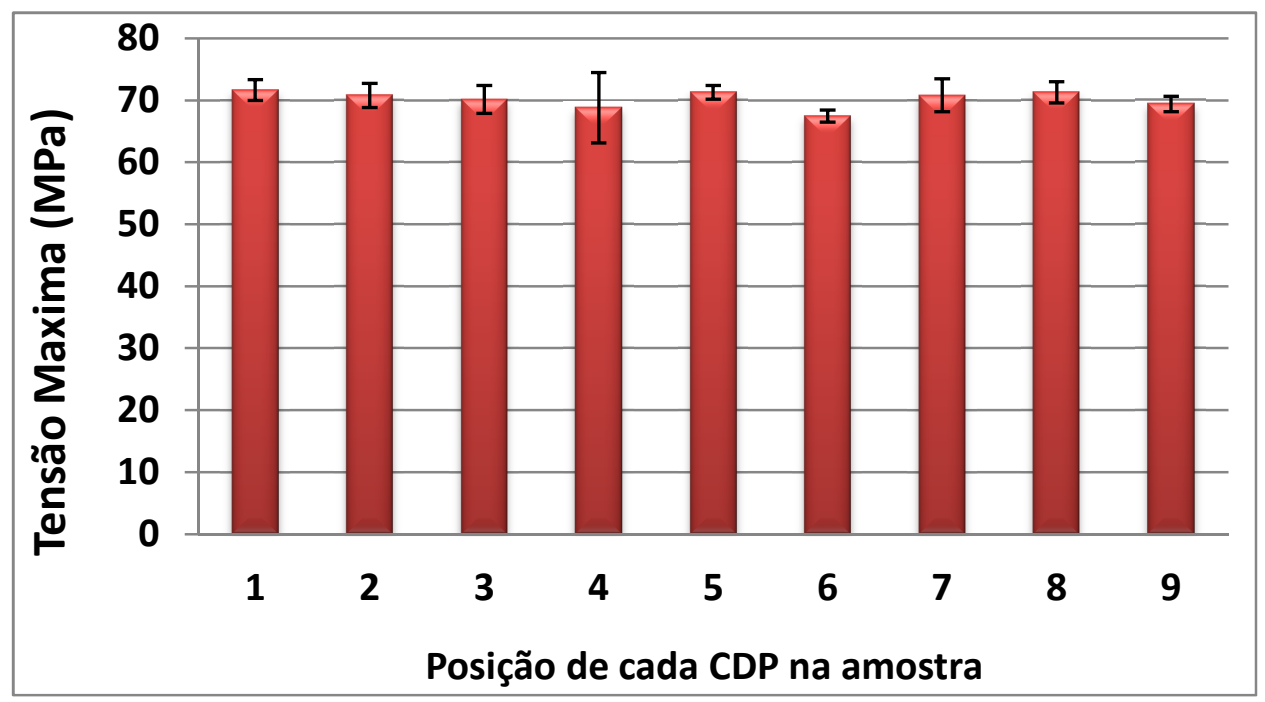

Figura 4.43 - Gráfico obtido da média das tensões máximas para cada posição da amostra retirada da área de colagem da junta de EPX-C do tipo virgem.

Para as amostras obtidas do CDP 6 (I) do tipo "impactado", a Tabela A.8 (em Apêndices) mostra os valores adquiridos de tensão máxima para cada posição da amostra retirada da área de colagem. Com esses valores foi gerado o gráfico da tensão máxima obtida e mostrado na Figura 4.44. Lembrando que tanto a Tabela A.8 (em Apêndices) como o gráfico da Figura 4.44, não apresentam média de valores, uma vez que apenas um CDP impactado foi seccionado na área de soldagem para gerar as amostras de 1 a 9 . 


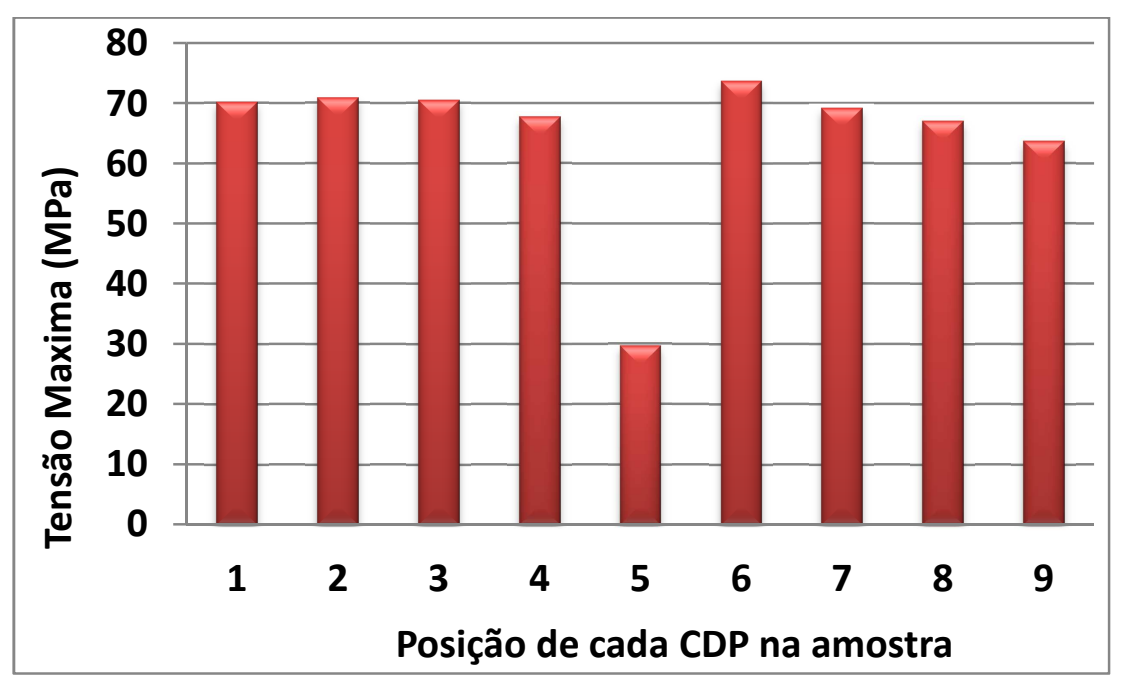

Figura 4.44 - Gráfico da tensão máxima para cada posição da amostra da área de colagem da junta de EPX-C do tipo impactada.

Com base nas tabelas e gráficos obtidos para o ensaio de ILSS para as amostras coladas descritas aqui, pode-se observar que:

$\checkmark$ As amostras obtidas dos espécimes "virgens" de EPX-C apresentaram regularidade nos valores médio de resistência ao longo das posições de 1 a 9 , sugerindo relativa uniformidade no processo de colagem aplicado.

$\checkmark$ Para a o CDP 6 (I) "impactado", a amostra 5 (onde concentrou o impacto único de $10 \mathrm{~J}$ ) mostrou resistência de aproximadamente 58\% menor que as amostras adjacentes, confirmando a baixa tolerância a danos desta classe de juntas compósitas de matriz polimérica. 


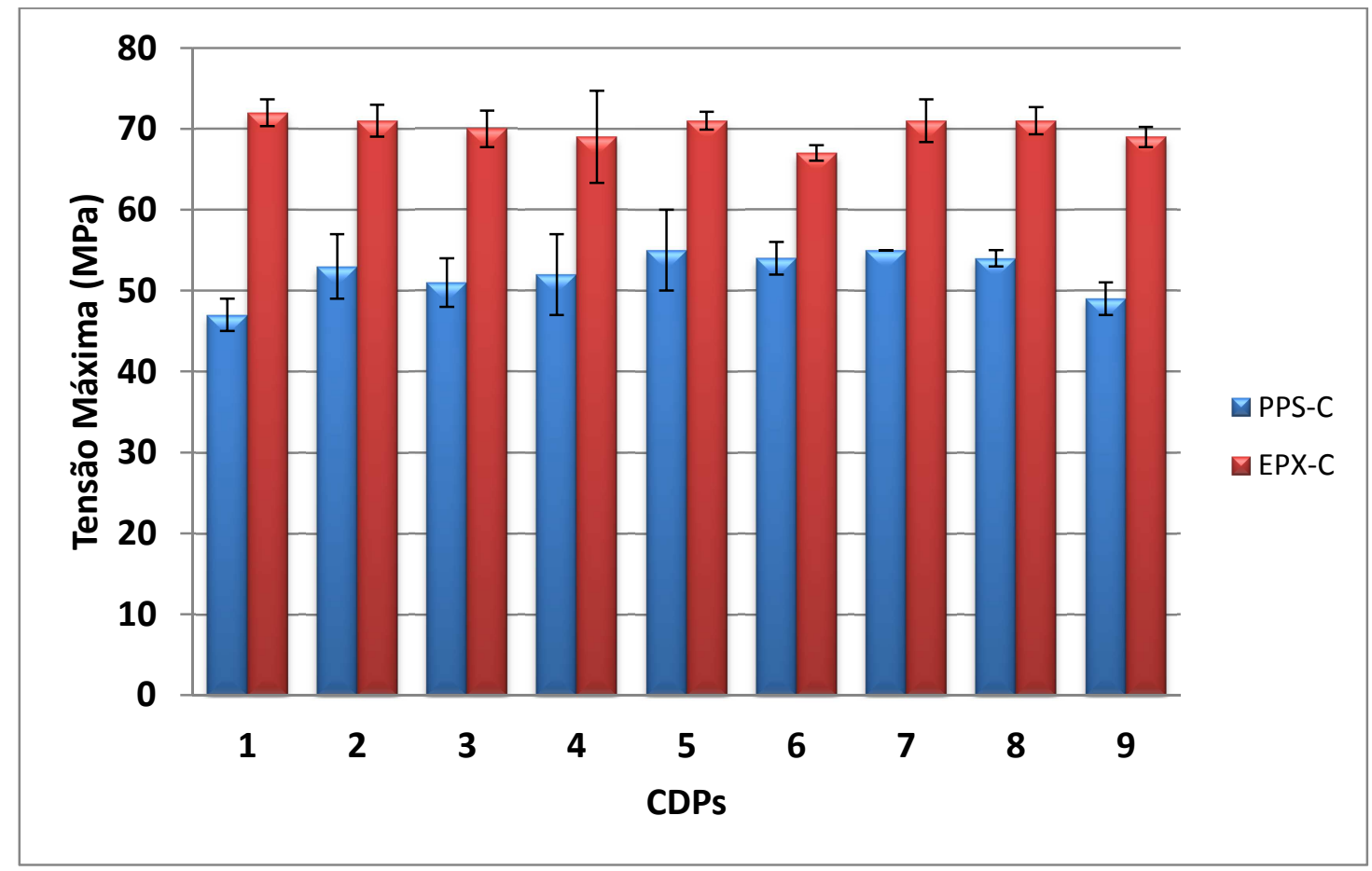

Figura 4.45 - Gráfico comparativo da média das tensões máximas para cada posição da amostra retirada da área de soldagem e colagem para a junta de PPS-C e EPX-C do tipo virgem, respectivamente.

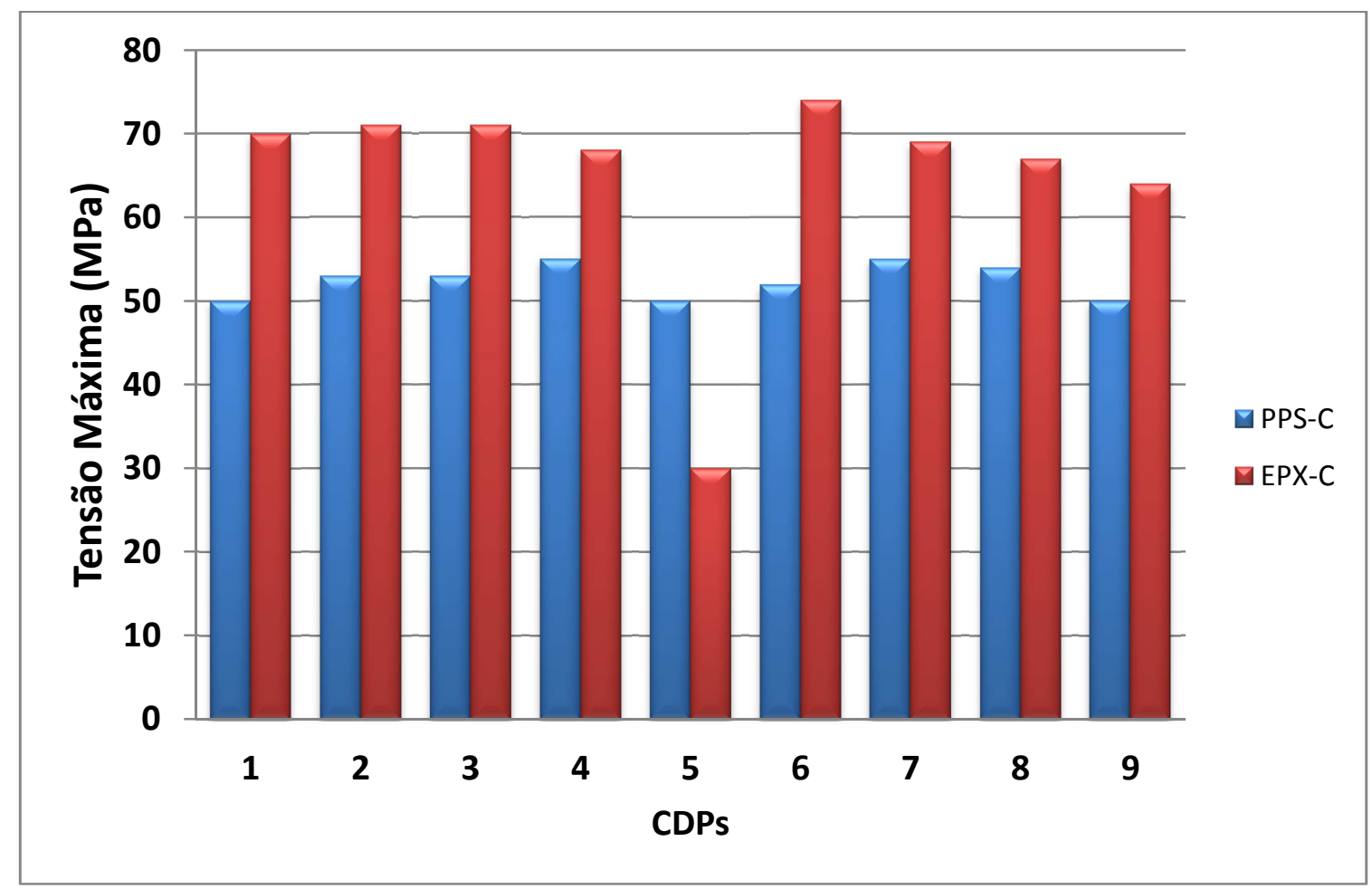

Figura 4.46 - Gráfico comparativo da média das tensões máximas para cada posição da amostra retirada da área de soldagem e colagem para a junta de PPS-C e EPX-C impactadas, respectivamente. 
As Figuras 5.45 e 5.46 comparam respectivamente, os valores de tensões máximas para as amostras de PPS-C e EPX-C virgem e impactada. Os gráficos comparativos ilustram os maiores valores de resistência para as amostras tiradas da junta de EPX-C, assim como evidenciam sua menor tolerância a danos devido ao baixo valor de resistência obtido pela amostra central afetada pelo impacto, quando comparada as amostras retiradas da junta de PPS-C 


\section{PRINCIPAIS CONCLUSÕES}

Após a submissão de juntas termoplásticas soldadas e de juntas termorrígidas coladas a diversos processos de degradação mecânica e higrotérmica aplicados de modo individual e combinado, seguida da determinação de suas propriedades mecânicas originais e residuais sob, respectivamente, flexão e cisalhamento interlaminar, e da subseqüente análise de falha dos espécimes fraturados, o presente estudo propiciou as seguintes conclusões principais:

$\checkmark$ A junta termorrígida colada EPX-C apresentou os maiores valores de resistência à flexão (F4P) para todas as condições ensaiadas, enquanto que a junta termoplástica PPS-C apresentou menores perdas percentuais desta propriedade após processos de degradação de naturezas higrotérmica e mecânica;

$\checkmark$ A análise dos dados relativos à rigidez em flexão em quatro pontos (F4P) indica que as juntas termorrígidas coladas EPX-C se mostraram mais susceptíveis aos condicionamentos aplicados para degradação de seu desempenho mecânico, evidenciando a menor tolerância a danos das juntas compósitas termorrígidas frente às termoplásticas;

$\checkmark$ O modo de falha macroscópico predominante em todas as juntas EPX-C foi o interfacial, enquanto que, para a junta PPS-C, o modo de falha após condicionamento higrotérmico foi interfacial e, nas demais condições, foi intralaminar;

Análises microscópicas evidenciaram alta adesão entre fibra/matriz, fraca interação entre a malha polimérica e o filme adesivo de colagem, e a presença de muitos vazios na interface de adesão dos laminados da junta EPX-C. Para a junta PPS-C foram reveladas uma possível baixa interação 
entre fibras de vidro e matriz de PPS na camada externa do laminado cujo núcleo é composto por fibras de carbono embebidas em polímero PPS, assim como fraca interação interfacial entre a malha metálica geradora de calor para a soldagem e os filmes puros de PPS que a revestem;

$\checkmark$ Nos ensaios de resistência ao cisalhamento interfacial (ILSS) de amostras extraídas da área de sobreposição das duas classes de juntas, os espécimes de EPX-C na condição virgem evidenciaram uma colagem uniforme ao longo da área de união, e as amostras retiradas da junta submetida a impacto único transversal revelaram que os danos se concentraram próximo ao ponto de impacto e afetam sobremaneira o comportamento residual desta região. Para a junta PPS-C, os espécimes de ensaio usinados a partir da junta virgem indicaram soldagem defectiva nas bordas da junta, enquanto que as aqueles extraídos da junta impactada não exibiram perda de resistência residual, indicando, assim com nos ensaios de flexão, maior tolerância a danos da junta termoplástica PPS-C frente a termorrígida EPX-C;

$\checkmark$ Os processos de fabricação de ambas as juntas apresentaram pontos falhos. Para a de PPS-C as áreas defectivas ficaram confinadas as bordas de entrada e saída de corrente elétrica, enquanto que para a de EPX-C os defeitos (vazios) ficaram homogeneamente distribuídos por toda a região de sobreposição da junta. 


\section{SUGESTÕES PARA TRABALHOS FUTUROS}

Como perspectiva para trabalhos futuros, vislumbra-se as seguintes possibilidades:

Aplicação de análise computacional para desenvolvimento de modelos em elementos finitos que representem o comportamento mecânico da junta virgem e pós-impacto. 


\section{REFERÊNCIAS BIBLIOGRÁFICAS}

AGEORGES C.; YE L.; HOU M. Experimental investigation of the resistance welding for thermoplastic-matrix composites. Part I. Heating element and heat transfer. Composite Science and Technology, vol. 60, p.1027-1039, 2000.

AGEORGES, C.; YE, L.; MAI, Y. W.; HOU, M. Advances in fusion bonding techniques for joining thermoplastic matrix composites: a review. Composites Part A, v. 32, p. 839-857, 2001.

AGEORGES, C.; YE, L.; MAI, Y. W.; HOU, M. Characteristics of resistance welding of lap shear coupons. Part I: Heat transfer. Composites Part A, v. 29A, p. 899-909, 1998.

ANDERSON, T. L. Fracture mechanics - fundamentals and application. $2^{\mathrm{a}}$ Ed. John Wiley and Sons, Inc, 1995.

ARIAS, M., ZIEGMANN, G. Impulse resistance welding: a new technique for joining advanced thermoplastic composite parts. Proceedings of the $41^{\text {st }}$ International SAMPE Symposium and Exhibition, Anaheim, USA, 1996.

BANEA M. D.; da SILVA L. F. M. Adhesively bonded joints in composite materials: an overview. Proceedings of the institution of mechanical engineers, Part L: Journal of materials Design and Aplications, 2009.

BENATAR A.; GUTOWSKI TG. Methods for fusion bonding thermo-pastic composites. SAMPE Quarterly, 18(1), p. 35-42, 1986. 
CALLISTER, W. D. Fundamentos da ciência e engenharia de materiais: uma abordagem integrada. $2^{2}$ Ed. Editora LTC, Rio de Janeiro, 2006.

CAMPBELL, F. C. Manufacturing technology for aerospace structural materials. $1^{\text {a }}$ Ed. Elsevier Ltda, 2006.

CÂNDIDO, G. M.; REZENDE, M. C.; DONADON M. V.; ALMEIDA, S. F. M. Fractography of aeronautical structural composite submitted to mode II interlaminar fracture toughness Test. Polímeros, Vol. 24, n.1, p.65-71, 2014.

CHAZERAIN, A. Characterization of resistance-welded thermoplastic composite double-lap joints.Thesis - Mechanical Engineering Department, McGill University, Montreal, 2009.

DE BAERE, I.; PAEPEGEM, W. V.; DEGRIECK, J. Feasibility Study of Fusion Bonding for Carbon Fabric Reinforced Polyphenylene Sulphide by Hot-Tool Welding. Journal of Thermoplastic Composite Materials, v. 25, March 2012.

POLIMENO U.; MEO M. Detecting barely visible impact damage detection on aircraft composites structures. Composite Structures. v. 91, p. 398-402, 2009.

DUBÉ M.; HUBERT P.; YOUSEFPOUR A.; DENAULT J. Fatigue failure characterization of resistance-welded thermoplastic composites skin/stringer joints. International Journal of Fatigue, v. 31, p. 719-725, 2009.

DUBÉ, M.; HUBERT, P.; GALLET, J. N. A. H.; STAVROV, D.; BERSEE, H. E. N.; YOUSEFPOUR, A. Fatigue performance characterization of resistance-welded thermoplastic composites. Composites Science and Technology, v. 68, p. 17591765, 2008. 
DUBÉ, M.; HUBERT, P.; NAH, J. G., STAVROV, D.; EN, H. B.; YOUSEFPOUR, A.; Metal mesh heating element size effect in resistance welding of thermoplastic composites, Journal of Composite Materials, v. 46, p. 911-919, 2011.

DUBÉ, M.; Static and fatigue behavior of thermoplastic composite laminates joined by resistance welding. Thesis - Department of Mechanical Engineering, McGill University, Montreal, 2007.

FERREIRA, J. A. M.; REIS, P. N.; COSTA, J. D. M.; RICHARDSON, M. O. W. Fatigue behaviour of composite adhesive lap joints. Composites Science and Technology, v. 62, p. 1373-1379. 2002.

GREENHALGH E. S. Failure analysis and fractography of polymer composites. Woodhead Publishing, CRC Press, USA, 2009.

GREENHALGH E. S.; HILEY M. J. Fractography of polymer composites: current status and future issues. Proceedings of the 13th European Conference on Composite Materials, Estocolmo, Suécia, 2008.

HOU, M.; YE, L.; MAI, Y. W. An experimental study of resistance welding of carbon fibre fabric reinforced polyetherimide (CF fabric/PEI) composite material. Applied Composite Materials, v. 6, p. 35-49, 1999.

http://www.a350xwb.com/sensational/shape

http://www.boeing.com/boeing/commercial/787family/787-10prod.page?

http://www.cnde.iastate.edu/ultrasonics-and-composites/modeling-cracks-anddelaminations-carbon-fiber-composites-frank-margetan. 
http://www.compositesworld.com/articles/a350-xwb-update-smart-manufacturing

http://www.compositesworld.com/articles/boeing-787-update

http://www.compositesworld.com/articles/thermoplastic-composites-gain-leadingedge-on-the-a380

http://www.flightglobal.com/news/aviation/

http://www.newairplane.com/787

http://www.premium-aerotec.com/en/Page1516.html

http://www.theengineer.co.uk/plastic-fantastic/1004930.article

HULL, D. An introduction to composite materials. Cambridge University Press, New York, USA, 1995.

HYER, M. W. Stress analysis of fiber-reinforced composite materials. McGrawHill, 1998.

WOSU S. N.; HUI D.; DANIEL L. Hygrothermal effects on the dynamic compressive properties of graphite/epoxy composite material. Composites Part B, v. 43, p. 841855, 2012.

JONES R. M. Mechanics of composite materials. $2^{a}$ Ed. Taylor \& Francis, 1999. 
KIM, J. H.; PARK, B. J.; HAN, Y. W. Evaluation of fatigue characteristics for adhesively-bonded composites stepped lap joints. Composite Structures, v. 66, p. 69-75, 2004.

KIM, K. S.; YOO, Y. M.; YI, Y. M.; KIM, C. G. Failure mode and strength of unidirectional composite single lap bonded joints with different bonding methods. Composite Structures, v. 72, p. 477-485. 2005.

LEE, H. K.; PYO, S. H.; KIM, B.R. On joint strengths, peel stresses and failure modes in adhesively bonded double-strap and supported single-lap GFRP joints. Composite Structures, article in press, 2008.

MATTHEWS, F. L.; RAWLINGS R. D. Composite materials: Engineering and science. Woodhead Publishing Limited. Cambridge England. 2003.

McCARVILLE, D. A., SCHAEFER H. A., "Processing and Joining of Thermoplastic Composites", ASM Handbook Vol. 21 Composites, ASM International, pp. 633-645, 2001.

MENDONÇA, P. T. R. Materiais compostos \& estruturas. $1^{a}$ Ed. Editora Manole Ltda, Barueri, 2005.

MICHAEL, J. T. Handbook of plastics joining: a practical guide, 2nd Ed. Plastics Design Library Staff, 1997.

MINGUET P. J.; O'BRIEN, T. K., "Analysis of Test Methods for Characterizing Skin/stringer Debonding Failures in Reinforced Composite Panels," Composite Materials: Testing and Design, Twelfth Volume, ASTM STP 1274, August 1996, p. 105-124, 1996. 
NETO, F. L.; PARDINI, L. C. Compósitos estruturais: ciência e tecnologia. 1를. Editora Edgard Blucher, São Paulo, 2006.

NIU, M. C. Y. Composite airframe structures. $1^{a}$ Ed. Conmilit Press Ltd., Hong Kong, 1992.

QUARESIMIN, M.; RICOTTA, M. Fatigue behaviour and damage evolution of single lap bonded joints in composite material. Composites Science and Technology, v. 66, p. 176-187, 2006.

RAPHAEL C. Variable-adhesive bonded joints. Appl Polym Symp, $n^{0}$ 3, p. 99-108, 1966.

REQUENA I. G., LOBERA A. S., FERNÁNDEZ L. M. V. Characterizing of meshes for resistance welding of high temperature reinforced laminate thermoplastic (RLT), Procedia Engineering - The Manufacturing Engineering Society International Conference (MESIC), v.63, p.556-563, 2013.

RHEAD, A. T.; MARCHANT, D.; BUTLER, R., Compressive strength of composite laminates following free edge impact. Composites Part A Applied Science and Manufacturing, 41 (9), pp. 1056-1065. 2010.

SCHWARTZ, M. M.; Joining of composite materials. ASM Int. p. 35-38, 1994.

SHI, H.; VILLEGAS, F. I.; BERSEE, E. N. H. Strength and failure modes in resistance welded thermoplastic composite joints: Effect of fibre-matrix adhesion and fibre orientation. Composites: Part A, V. 55, p. 1-10, 2013. 
SILVA, L. F. M.; NEVES, P.J.C.; ADAMS, R.D.; SPELT, J.K. Analytical models of adhesively bonded joints - Part I: Literature survey. International Journal of Adhesion \& Adhesives. V.29, p. 319-330, 2009.

SILVERMAN E. M.; GRIESE R. A. Joining methods for graphite/PEEK thermoplastic composites. SAMPE J 1989; V.25, p. 34-38, 1989.

Standard test method for moisture in a graphite sample, Designation ASTM C562 (2010) ASTM International, v.05.05, West Conshohocken, Pennsylvania, Philadelphia, 2p.

Standard guide for use of adhesive-bonded single lap-joint specimen test results. ASTM- D4896. 2008.

Standard Guide for Use of Adhesive-Bonded Single Lap-Joint Specimen Test Results. ASTM- D4896. 2008.

Standard practice for classifying failure modes in fiber-reinforced-plastic FRP joints. ASTM D 5573. Annual Book of ASTM Standards, 15.03, 2002.

Standard test method for apparent shear strength of single-lap-joint adhesively bonded metal specimens by tension loading (metal-to-metal). ASTM-D1002. 2010.

Standard Test Method for Compressive Properties of Polymer Matrix Composite Materials with Unsupported Gage Section by Shear Loading. ASTM- D3410. 2008.

Standard Test Method for Compressive Properties of Polymer Matrix Composite Materials Using a Combined Loading Compression (CLC) Test Fixture. ASTMD6641. 2009. 
Standard Test Method for Determining Strength of Adhesively Bonded Rigid Plastic Lap-Shear Joints in Shear by Tension Loading. ASTM- D3163. 2001.

Standard test method for fatigue properties of adhesives in shear by tension loading (metal/metal). Annual Book of ASTM Standards, ASTM-D3166. 2012.

Standard Test Method for Flexural Properties of Polymer Matrix Composite Materials. ASTM- D7264. 2007.

Standard Test Method for Lap Shear Adhesion for Fiber Reinforced Plastic (FRP) Bonding. ASTM- D5868. 2001.

Standard Test Method for Measuring the Damage Resistance of a Fiber-Reinforced Polymer Matrix Composite to a Drop-Weight Impact Event. ASTM- D7136. 2005.

Standard Test Method for Moisture Absorption Properties and Equilibrium Conditioning of Polymer Matrix Composite Materials. ASTM- D5229. 2012.

Standard Test Method for Short-Beam Strength of Polymer Matrix Composite Materials and Their Laminates. ASTM- D2344. 2006.

Standard test method for strength properties of adhesives in shear by tension loading of single-lap-joint laminated assemblies. ASTM-D3165. 2007.

Standard Test Method for Strength Properties of Adhesives in Shear by Tension Loading of Single-Lap-Joint Laminated Assemblies. ASTM- D3165. 2007. 
Standard Test Method for Thick-Adherend Metal Lap-Shear Joints for Determination of the Stress-Strain Behavior of Adhesives in Shear by Tension Loading. ASTMD5656. 2010.

STAVROV D., BERSEE, H. E. N. Thermal Aspects in Resistance Welding of thermoplastic Composites. ASME Summer Heat Transfer Conference, Las Vegas, USA, 2003.

STAVROV, D.; BERSEE, H. E. N.; Resistance welding of thermoplastic compositesan overview, Composites: Part A, vol. 36, p. 39-54, 2005.

SWAIN R. E.; BAKIS C. E.; REIFSNIDER K. L., Composite materials: fatigue and fracture. ASTM Special Technical Publication 1156, Philadelphia, p.552-574, 1993.

TALBOT, E.; Manufacturing process modeling of thermoplastic composite resistance welding. Thesis - Mechanical Engineering Department, McGill University Montreal, 2005

TARPANI J. R.; MILAN M. T., SPINELLI D.; BOSE W. W. Mechanical performance of carbon-epoxy laminates - part II: quasi-static and fatigue tensile properties, Materials Research, v.9, p.121-130, 2006.

TARPANI, J. R.; MALUF, O.; GATTI, M. C. A. ; Charpy impact toughness of conventional and advanced composite laminates for aircraft construction. Materials Research (Impresso), v. 12, p. 395-403, 2009.

VAIDYA, U. K.; GAUTAM, A. R. S.; HOSUR, M.; DUTTA, P. Experimental-numerical studies of transverse impact response of adhesively bonded lap joints in composite structures. International Journal of Adhesion \& Adhesives, v. 26, p. 184-198, 2006. 
VODICKA, R. Thermoplastics for airframe applications a review of the properties and repair methods for thermoplastic composites. DSTO Aeronautical and Maritime Research Laboratory, 1996.

YARLAGADDA S.; FINK B. K, GILLESPIE Jr. J. W. Resistive susceptor design for uniform heating during induction bonding of composites. Journal of Thermoplastic Composite Materials, p.321-337, 1998.

YOUSEFPOUR, A., SIMARD, M., OCTEAU, M.-A., HOJJATI, M. Process Optimization of Resistance-Welded Thermoplastic Composites Using Metal Mesh Heating Elements. SAMPE, Long Beach, USA, 2005.

ZENG, Q.; SUN, C. T. Fatigue performance of a bonded wavy composite lap joint. Purdue University. School of Aeronautics and Astronautics, West Lafayette, IN 47907, USA 2003. 


\section{APÊNDICES}

\subsection{Apêndice A - Tabelas}

Tabela A.1 - Valores de força, deslocamento máximo e desvio padrão obtidos nos ensaios de flexão sob quatro pontos para as juntas termoplásticas soldadas de PPSC.

\begin{tabular}{|c|c|c|c|c|c|c|c|}
\hline & \multirow{2}{*}{\multicolumn{2}{|c|}{ Média }} & \multirow{2}{*}{\multicolumn{2}{|c|}{ Desvio Padrão }} \\
\hline & & & & & & & \\
\hline Condição & Denominação & $\begin{array}{c}\text { Força } \\
\text { máxima(N) }\end{array}$ & $\begin{array}{l}\text { Deslocamento } \\
\text { máximo }(\mathrm{mm})\end{array}$ & Força (N) & $\begin{array}{c}\text { Deslocamento } \\
(\mathrm{mm})\end{array}$ & Força $(\mathrm{N})$ & $\begin{array}{c}\text { Deslocamento } \\
\text { (mm) }\end{array}$ \\
\hline PPS 24 (virgem) & \multirow{3}{*}{ v } & 2243 & 6,61 & \multirow{3}{*}{2208} & \multirow{3}{*}{6,5} & \multirow{3}{*}{42} & \multirow{3}{*}{0,12} \\
\hline PPS 23 (virgem) & & 2218 & 6,44 & & & & \\
\hline PPS 26 (virgem) & & 2161 & 6,37 & & & & \\
\hline PPS 45 (impactado) & \multirow{4}{*}{1} & 2560 & 7,08 & \multirow{4}{*}{2160} & \multirow{4}{*}{6,2} & \multirow{4}{*}{267} & \multirow{4}{*}{0,60} \\
\hline PPS 33 (impactado) & & 2050 & 6,00 & & & & \\
\hline PPS 40 (impactado) & & 2026 & 6,04 & & & & \\
\hline PPS 99 (impactado) & & 2003 & 5,72 & & & & \\
\hline PPS 27 (condicionado) & C & 1535 & 4,70 & 1535 & 4,7 & 0 & 0 \\
\hline PPS 42 (impactado + condicionado) & \multirow{3}{*}{$\mathrm{I}+\mathrm{C}$} & 1500 & 4,94 & \multirow{3}{*}{1497} & \multirow{3}{*}{4,9} & \multirow{3}{*}{47} & \multirow{3}{*}{0,07} \\
\hline PPS 48 (impactado + condicionado) & & 1448 & 4,82 & & & & \\
\hline PPS 16 (impactado + condicionado) & & 1543 & 4,81 & & & & \\
\hline 17 (fadigado) & \multirow{2}{*}{$\mathrm{F}$} & 2203 & 6,43 & \multirow{2}{*}{2238} & \multirow[b]{2}{*}{6,6} & \multirow{2}{*}{50} & \multirow{2}{*}{0,29} \\
\hline 20 (fadigado) & & 2274 & 6,84 & & & & \\
\hline 5 (impactado + fadigado) & \multirow{2}{*}{$\mathrm{I}+\mathrm{F}$} & 1932 & 6,49 & \multirow[b]{2}{*}{1928} & \multirow[b]{2}{*}{6,3} & \multirow[b]{2}{*}{7} & \multirow{2}{*}{0,25} \\
\hline 10 (impactado + fadigado) & & 1923 & 6,13 & & & & \\
\hline 11 (impactado + condicionado + fadigado) & \multirow{2}{*}{$\mathrm{I}+\mathrm{C}+\mathrm{F}$} & 1459 & 4,75 & \multirow{2}{*}{1491} & \multirow{2}{*}{4,8} & \multirow{2}{*}{46} & \multirow{2}{*}{0,07} \\
\hline 43 (impactado + condicionado + fadigado) & & 1523 & 4,85 & & & & \\
\hline
\end{tabular}


Tabela A.2 - Valores de força, deslocamento máximo e desvio padrão obtidos nos ensaios de flexão sob quatro pontos para as juntas termorrígidas coladas de EPX-C.

\begin{tabular}{|c|c|c|c|c|c|c|c|}
\hline & \multirow{2}{*}{\multicolumn{2}{|c|}{ Média }} & \multirow{2}{*}{\multicolumn{2}{|c|}{ Desvio padrão }} \\
\hline & & & & & & & \\
\hline Condição & Denominação & $\begin{array}{c}\text { Força } \\
\text { máxima }(\mathrm{N})\end{array}$ & $\begin{array}{l}\text { Deslocamento } \\
\text { máximo }(\mathrm{mm})\end{array}$ & Força (N) & $\begin{array}{c}\text { Deslocamento } \\
(\mathrm{mm})\end{array}$ & Força $(\mathrm{N})$ & $\begin{array}{c}\text { Deslocamento } \\
(\mathrm{mm})\end{array}$ \\
\hline EPX 1111 (virgem) & \multirow{3}{*}{ V } & 4645 & 10,70 & \multirow{3}{*}{4824} & \multirow{3}{*}{11,1} & \multirow{3}{*}{627} & \multirow{3}{*}{0,53} \\
\hline EPX 1115 (virgem) & & 5521 & 11,70 & & & & \\
\hline EPX 8 (virgem) & & 4306 & 10,91 & & & & \\
\hline & & & & & & & \\
\hline EPX 8 (impactado) & \multirow{3}{*}{1} & 4945 & 11,12 & \multirow{3}{*}{4350} & \multirow{3}{*}{10,6} & \multirow{3}{*}{768} & \multirow{3}{*}{1,09} \\
\hline EPX 7 (impactado) & & 3483 & 9,36 & & & & \\
\hline EPX 99 (impactado) & & 4622 & 11,36 & & & & \\
\hline & & & & & & & \\
\hline EPX 305 (condicionado) & $\mathrm{C}$ & 3843 & 10,02 & 3843 & 10,0 & 0 & 0 \\
\hline & & & & & & & \\
\hline EPX 4 (impactado + condicionado) & \multirow{2}{*}{$1+C$} & 3044 & 8,71 & \multirow{2}{*}{2802} & \multirow{2}{*}{8,5} & \multirow{2}{*}{342} & \multirow{2}{*}{0,32} \\
\hline EPX 61 (impactado + condicionado) & & 2560 & 8,26 & & & & \\
\hline 4 (fadigado) & \multirow{2}{*}{$\mathrm{F}$} & 3140 & 9,03 & \multirow{2}{*}{3105} & \multirow{2}{*}{9,1} & \multirow{2}{*}{50} & \multirow{2}{*}{0,03} \\
\hline 10 (fadigado) & & 3069 & 9,07 & & & & \\
\hline 5 (impactado + fadigado) & \multirow{2}{*}{$1+F$} & 4416 & 11,27 & \multirow{2}{*}{4672} & \multirow{2}{*}{11,6} & \multirow{2}{*}{362} & \multirow{2}{*}{0,47} \\
\hline 71 (impactado + fadigado) & & 4928 & 11,94 & & & & \\
\hline 3 (impactado + condicionado + fadigado) & \multirow{2}{*}{$I+C+F$} & 2808 & 8,53 & \multirow{2}{*}{2727,5} & \multirow[b]{2}{*}{8,5} & \multirow{2}{*}{114} & \multirow{2}{*}{0,02} \\
\hline 10 (impactado + condicionado + fadigado) & & 2647 & 8,56 & & & & \\
\hline
\end{tabular}

Tabela A.3 - Para a junta termoplástica soldada de PPS-C o "X" marca a análise que foi realizada para cada CDP de acordo com a sua condição. Portanto, os CDPs assinalados abaixo tiveram a superfície de fratura fotografada, inspecionada por estereoscopia e microscopia eletrônica de varredura (MEV).

\begin{tabular}{|c|c|c|c|c|}
\hline \multicolumn{5}{|c|}{ PPS } \\
\hline Condição & Denominação & Superfície de fratura & Estereoscopia & MEV \\
\hline PPS 24 (virgem) & \multirow{3}{*}{$\mathrm{v}$} & $x$ & & \\
\hline PPS 23 (virgem) & & $x$ & $x$ & $\mathrm{x}$ \\
\hline PPS 26 (virgem) & & $\mathrm{x}$ & & \\
\hline PPS 45 (impactado) & \multirow{4}{*}{ I } & $\mathrm{x}$ & & \\
\hline PPS 33 (impactado) & & $x$ & $x$ & $\mathrm{x}$ \\
\hline PPS 40 (impactado) & & $x$ & & \\
\hline PPS 99 (impactado) & & $x$ & & \\
\hline PPS 27 (condicionado) & $\mathrm{C}$ & $x$ & & \\
\hline PPS 42 (impactado + condicionado) & \multirow{3}{*}{$\mathrm{I}+\mathrm{C}$} & $x$ & $x$ & $x$ \\
\hline PPS 48 (impactado + condicionado) & & $\mathrm{x}$ & & \\
\hline PPS 16 (impactado + condicionado) & & $\mathrm{x}$ & & \\
\hline 17 (fadigado) & \multirow{2}{*}{$\mathrm{F}$} & $\mathrm{x}$ & $\mathrm{x}$ & $\mathrm{x}$ \\
\hline 20 (fadigado) & & $\mathrm{x}$ & & \\
\hline 5 (impactado + fadigado) & \multirow{2}{*}{$\mathrm{I}+\mathrm{F}$} & $\mathrm{x}$ & $\mathrm{x}$ & $\mathrm{x}$ \\
\hline 10 (impactado + fadigado) & & $\mathrm{x}$ & & \\
\hline 11 (impactado + condicionado + fadigado) & \multirow{2}{*}{$\mathrm{I}+\mathrm{C}+\mathrm{F}$} & $\mathrm{x}$ & & \\
\hline 43 (impactado + condicionado + fadigado) & & $\mathrm{x}$ & $\mathrm{x}$ & $\mathrm{x}$ \\
\hline
\end{tabular}


Tabela A.4 - Para o EPX-C o "X" marca a análise que foi realizada para cada CDP de acordo com a sua condição. Portanto, os CDPs assinalados abaixo tiveram a superfície de fratura fotografada, inspecionada por estereoscopia e microscopia eletrônica de varredura (MEV).

\begin{tabular}{|c|c|c|c|c|}
\hline \multicolumn{5}{|c|}{ EPX } \\
\hline Condição & Denominação & Superfície de fratura & Estereoscopia & MEV \\
\hline EPX 1111 (virgem) & \multirow{3}{*}{$\mathrm{v}$} & $\mathrm{x}$ & & \\
\hline EPX 1115 (virgem) & & $\mathrm{x}$ & $\mathrm{x}$ & $\mathrm{x}$ \\
\hline EPX 8 (virgem) & & $\mathrm{x}$ & & \\
\hline EPX 8 (impactado) & \multirow{3}{*}{ I } & $\mathrm{x}$ & & \\
\hline EPX 7 (impactado) & & $\mathrm{x}$ & $\mathrm{x}$ & $\mathrm{x}$ \\
\hline EPX 99 (impactado) & & $\mathrm{x}$ & & \\
\hline EPX 305 (condicionado) & $\mathrm{C}$ & $\mathrm{x}$ & & \\
\hline EPX 4 (impactado + condicionado) & \multirow{2}{*}{$\mathrm{I}+\mathrm{C}$} & $\mathrm{x}$ & $\mathrm{x}$ & $\mathrm{x}$ \\
\hline EPX 61 (impactado + condicionado) & & $\mathrm{x}$ & & \\
\hline 4 (fadigado) & \multirow{2}{*}{$\mathrm{F}$} & $\mathrm{x}$ & & \\
\hline 10 (fadigado) & & $\mathrm{x}$ & $\mathrm{x}$ & $\mathrm{x}$ \\
\hline 5 (impactado + fadigado) & \multirow{2}{*}{$\mathrm{I}+\mathrm{F}$} & $\mathrm{x}$ & $\mathrm{x}$ & $\mathrm{x}$ \\
\hline 71 (impactado + fadigado) & & $\mathrm{x}$ & & \\
\hline 3 (impactado + condicionado + fadigado) & \multirow{2}{*}{$\mathrm{I}+\mathrm{C}+\mathrm{F}$} & $\mathrm{x}$ & $\mathrm{x}$ & $\mathrm{x}$ \\
\hline 10 (impactado + condicionado + fadigado) & & $\mathrm{x}$ & & \\
\hline
\end{tabular}

Tabela A.5 - Valores de tensão obtidos no ensaio de ILSS para cada amostra com a respectiva média e desvio padrão para cada posição (de 1 a 9) na junta de PPS-C.

\begin{tabular}{|c|c|c|c|c|c|c|c|}
\hline \multicolumn{2}{|c|}{ CDP 21 - PPS } & \multicolumn{2}{|c|}{ CDP 37 - PPS } & \multicolumn{2}{|c|}{ CDP 36 - PPS } & \multirow{2}{*}{$\begin{array}{l}\text { Tensão Média } \\
\text { (MPa) }\end{array}$} & \multirow[b]{2}{*}{ Desvio Padrão } \\
\hline Amostras & $\begin{array}{l}\text { Tensão } \\
\text { (MPa) }\end{array}$ & Amostras & $\begin{array}{l}\text { Tensão } \\
\text { (MPa) }\end{array}$ & Amostras & $\begin{array}{l}\text { Tensão } \\
\text { (MPa) }\end{array}$ & & \\
\hline 1 & 44 & 1 & 48 & 1 & 49 & 47 & 2 \\
\hline 2 & 54 & 2 & 56 & 2 & 49 & 53 & 4 \\
\hline 3 & 53 & 3 & 52 & 3 & 48 & 51 & 3 \\
\hline 4 & 55 & 4 & 55 & 4 & 46 & 52 & 5 \\
\hline 5 & 57 & 5 & 58 & 5 & 49 & 55 & 5 \\
\hline 6 & 55 & 6 & 55 & 6 & 52 & 54 & 2 \\
\hline 7 & 55 & 7 & 55 & 7 & 54 & 55 & 0 \\
\hline 8 & 55 & 8 & 53 & 8 & 53 & 54 & 1 \\
\hline 9 & 52 & 9 & 47 & 9 & 48 & 49 & 2 \\
\hline
\end{tabular}


Tabela A.6 - Valores de tensão obtidos no ensaio de ILSS para cada posição (de 1 a 9) na junta de PPS-C previamente impactada.

\begin{tabular}{|c|c|}
\hline \multicolumn{2}{|c|}{ CDP 47 - PPS } \\
\hline Amostras & $\begin{array}{c}\text { Tensão } \\
\text { (MPa) }\end{array}$ \\
\hline $\mathbf{1}$ & 50 \\
\hline $\mathbf{2}$ & 53 \\
\hline $\mathbf{3}$ & 53 \\
\hline $\mathbf{4}$ & 55 \\
\hline $\mathbf{5}$ & 50 \\
\hline $\mathbf{6}$ & 52 \\
\hline $\mathbf{7}$ & 55 \\
\hline $\mathbf{8}$ & 54 \\
\hline $\mathbf{9}$ & 50 \\
\hline
\end{tabular}

Tabela A.7 - Valores de tensão obtidos no ensaio de ILSS para cada amostra com a respectiva média e desvio padrão para cada posição (de 1 a 9) na junta de EPX-C.

\begin{tabular}{|c|c|c|c|c|c|c|c|}
\hline \multicolumn{2}{|c|}{ CDP 3010 - EPX } & \multicolumn{2}{|c|}{ CDP 301 - EPX } & \multicolumn{2}{|c|}{ CDP 302 - EPX } & \multirow{2}{*}{$\begin{array}{c}\text { Tensão Média } \\
\text { (MPa) }\end{array}$} & \multirow[b]{2}{*}{ Desvio Padrão } \\
\hline Amostras & $\begin{array}{l}\text { Tensão } \\
\text { (MPa) }\end{array}$ & Amostras & $\begin{array}{l}\text { Tensão } \\
\text { (MPa) }\end{array}$ & Amostras & $\begin{array}{c}\text { Tensão } \\
\text { (MPa) }\end{array}$ & & \\
\hline 1 & 73 & 1 & 70 & 1 & 73 & 72 & 2 \\
\hline 2 & 72 & 2 & 72 & 2 & 69 & 71 & 2 \\
\hline 3 & 72 & 3 & 68 & 3 & 71 & 70 & 2 \\
\hline 4 & 74 & 4 & 63 & 4 & 69 & 69 & 6 \\
\hline 5 & 72 & 5 & 70 & 5 & 71 & 71 & 1 \\
\hline 6 & 68 & 6 & 68 & 6 & 66 & 67 & 1 \\
\hline 7 & 72 & 7 & 72 & 7 & 68 & 71 & 3 \\
\hline 8 & 71 & 8 & 73 & 8 & 70 & 71 & 2 \\
\hline 9 & 68 & 9 & 69 & 9 & 71 & 69 & 1 \\
\hline
\end{tabular}


Tabela A.8 - Valores de tensão obtidos no ensaio de ILSS para cada posição (de 1 a 9) na junta de EPX-C previamente impactada.

\begin{tabular}{|c|c|}
\hline \multicolumn{2}{|c|}{ CDP 6 I - EPX } \\
\hline Amostras & $\begin{array}{c}\text { Tensão } \\
\text { (MPa) }\end{array}$ \\
\hline $\mathbf{1}$ & 70 \\
\hline $\mathbf{2}$ & 71 \\
\hline $\mathbf{3}$ & 71 \\
\hline $\mathbf{4}$ & 68 \\
\hline $\mathbf{5}$ & 30 \\
\hline $\mathbf{6}$ & 74 \\
\hline $\mathbf{7}$ & 69 \\
\hline $\mathbf{8}$ & 67 \\
\hline $\mathbf{9}$ & 64 \\
\hline
\end{tabular}


8.2 Apêndice B - Figuras

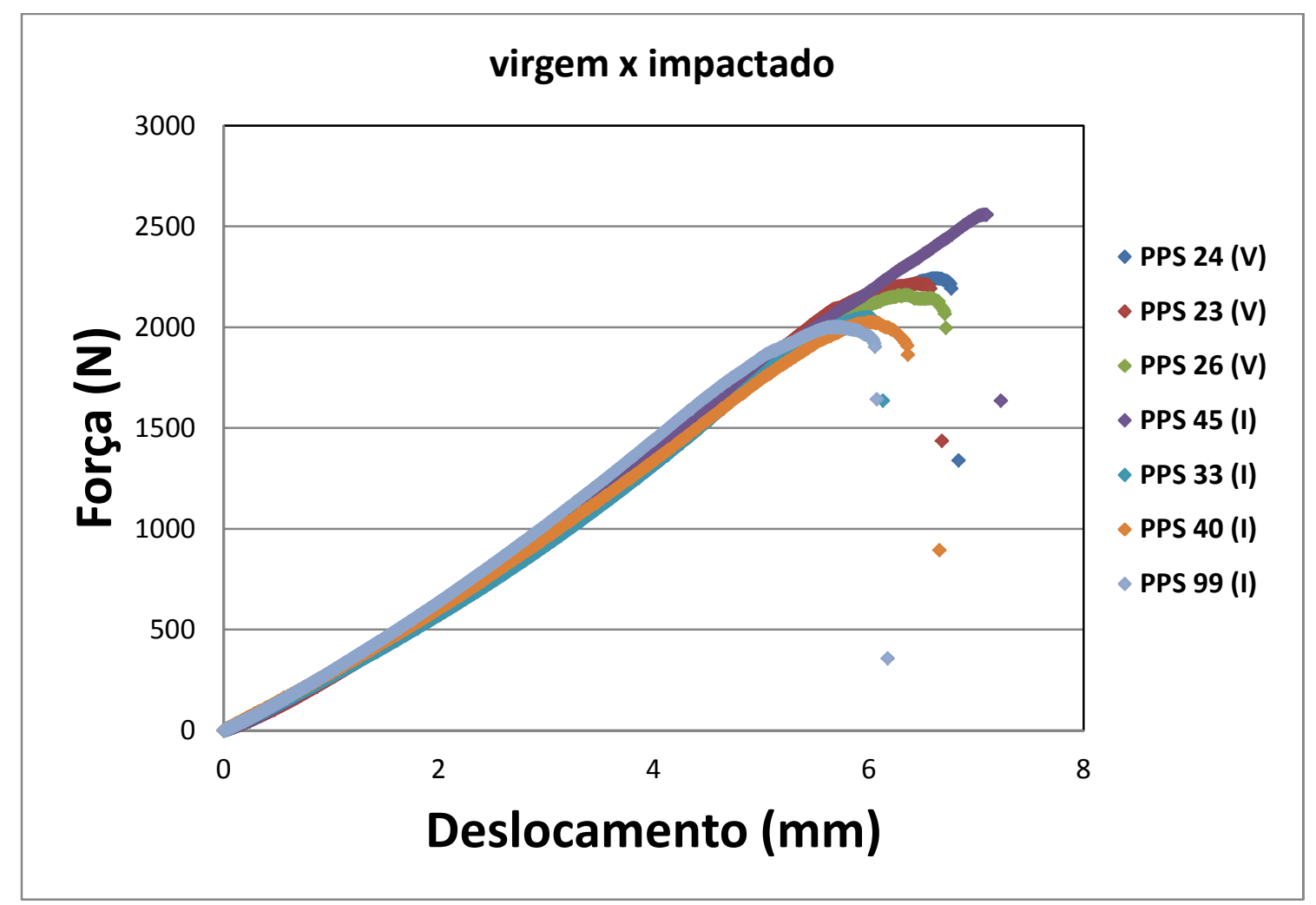

(a) 


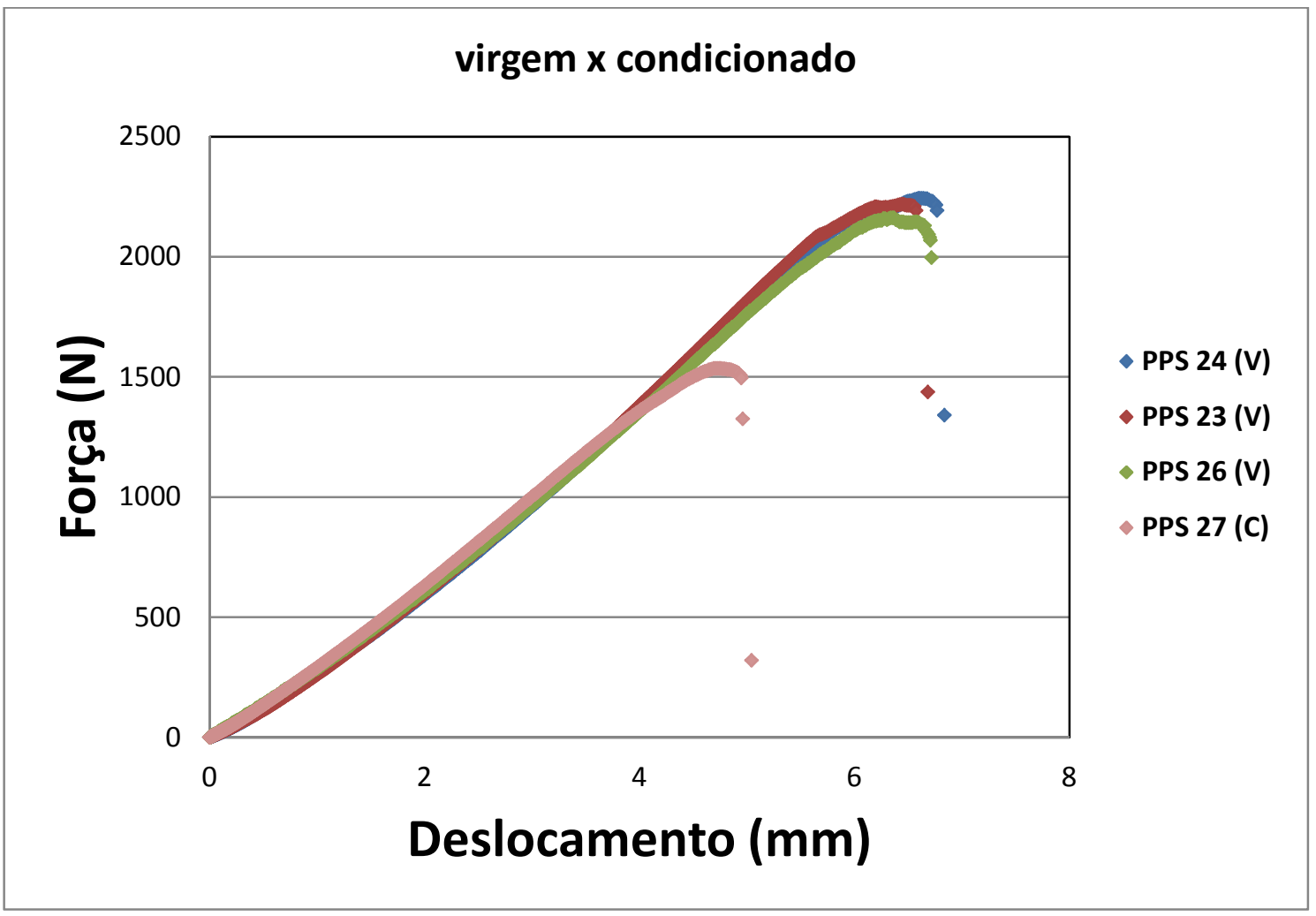

(b)

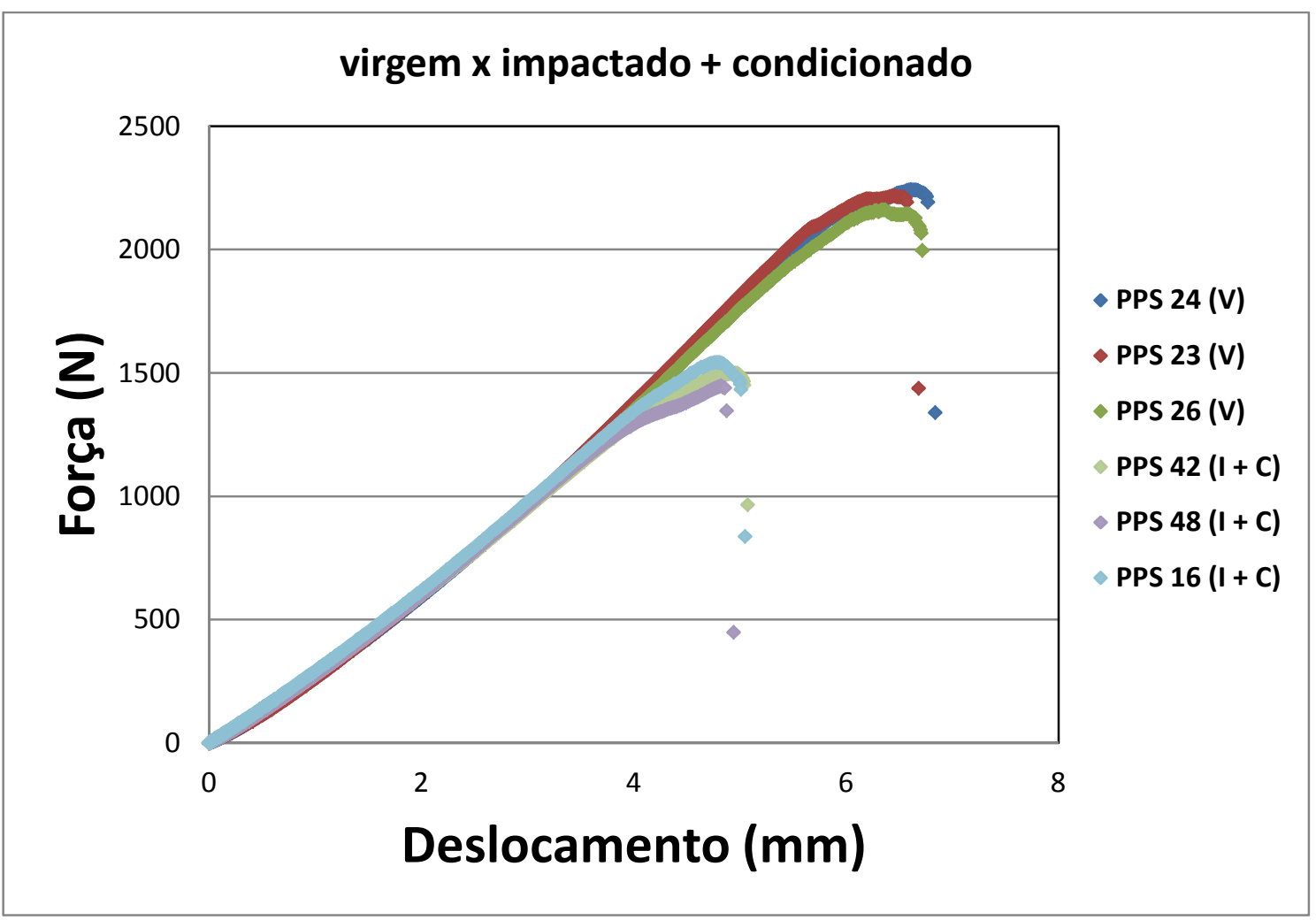

(c) 


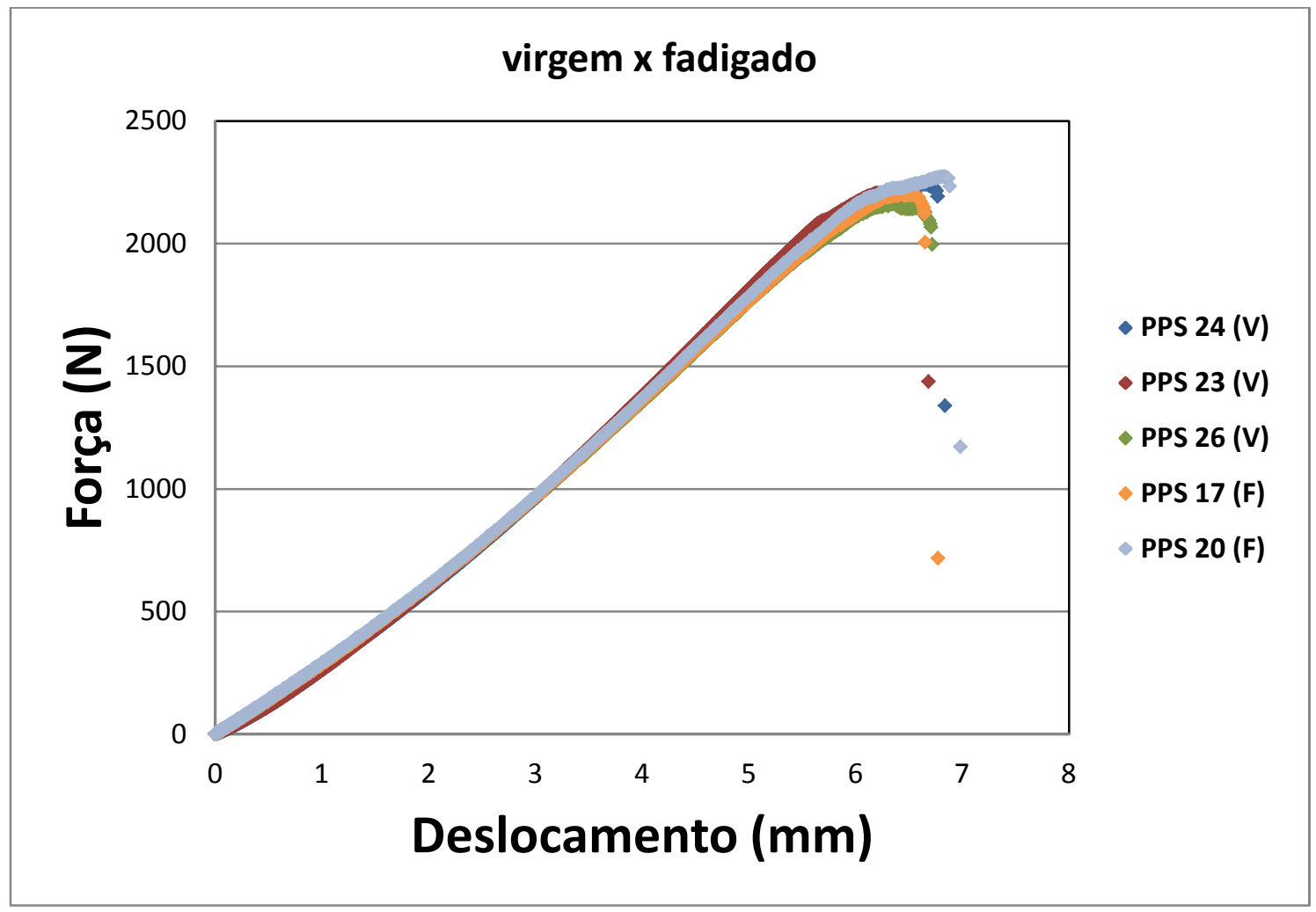

(d)

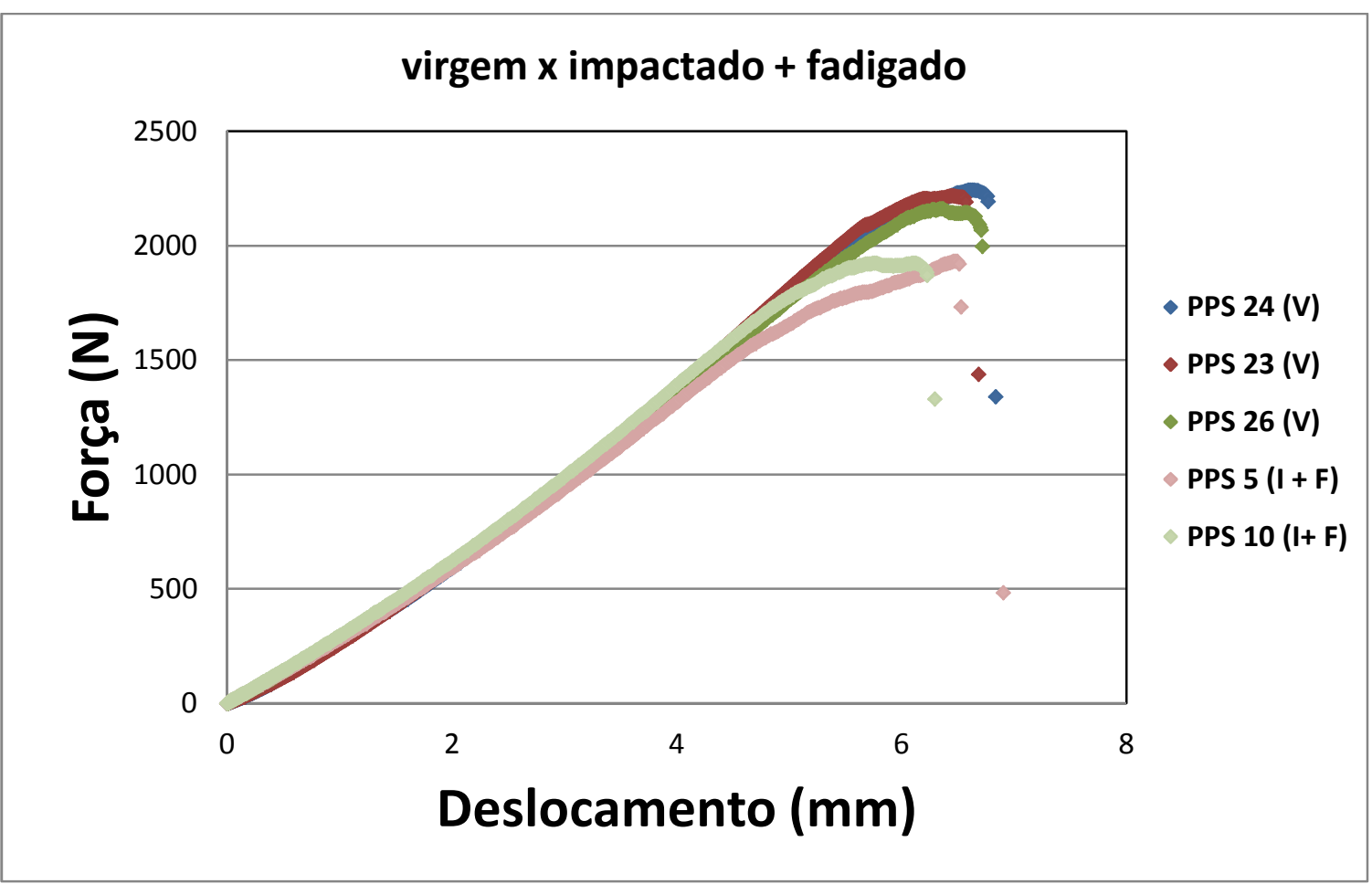

(e) 


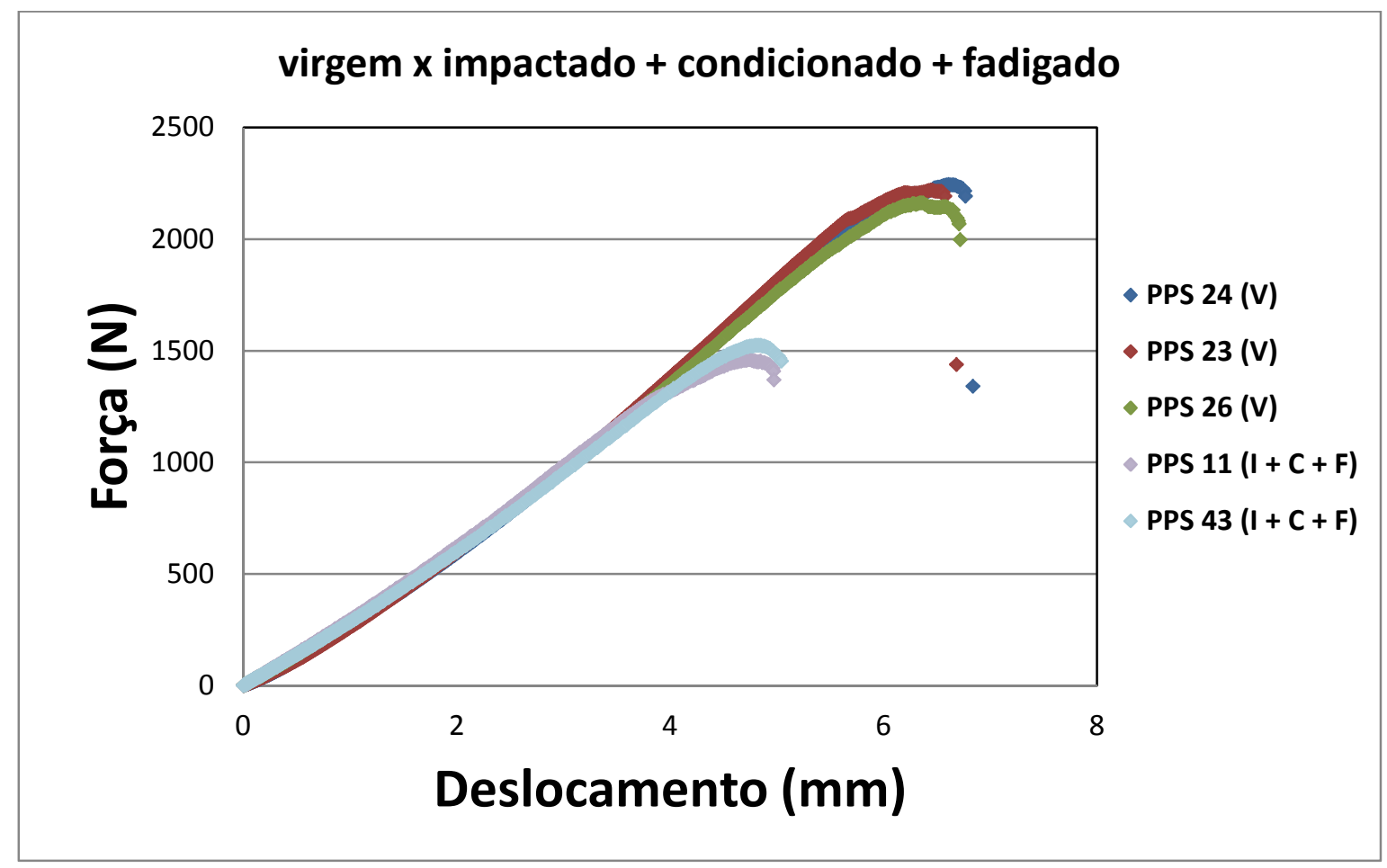

(f)

Figura B.1 - Gráficos de força x deslocamento para o PPS-C. Comparando as condições "virgem versus impactado" (a), "virgem versus condicionado" (b), "virgem versus impactado + condicionado" (c), "virgem versus fadigado" (d), "virgem versus impactado + fadigado" (e), "virgem versus impactado + condicionado + fadigado" (f). 


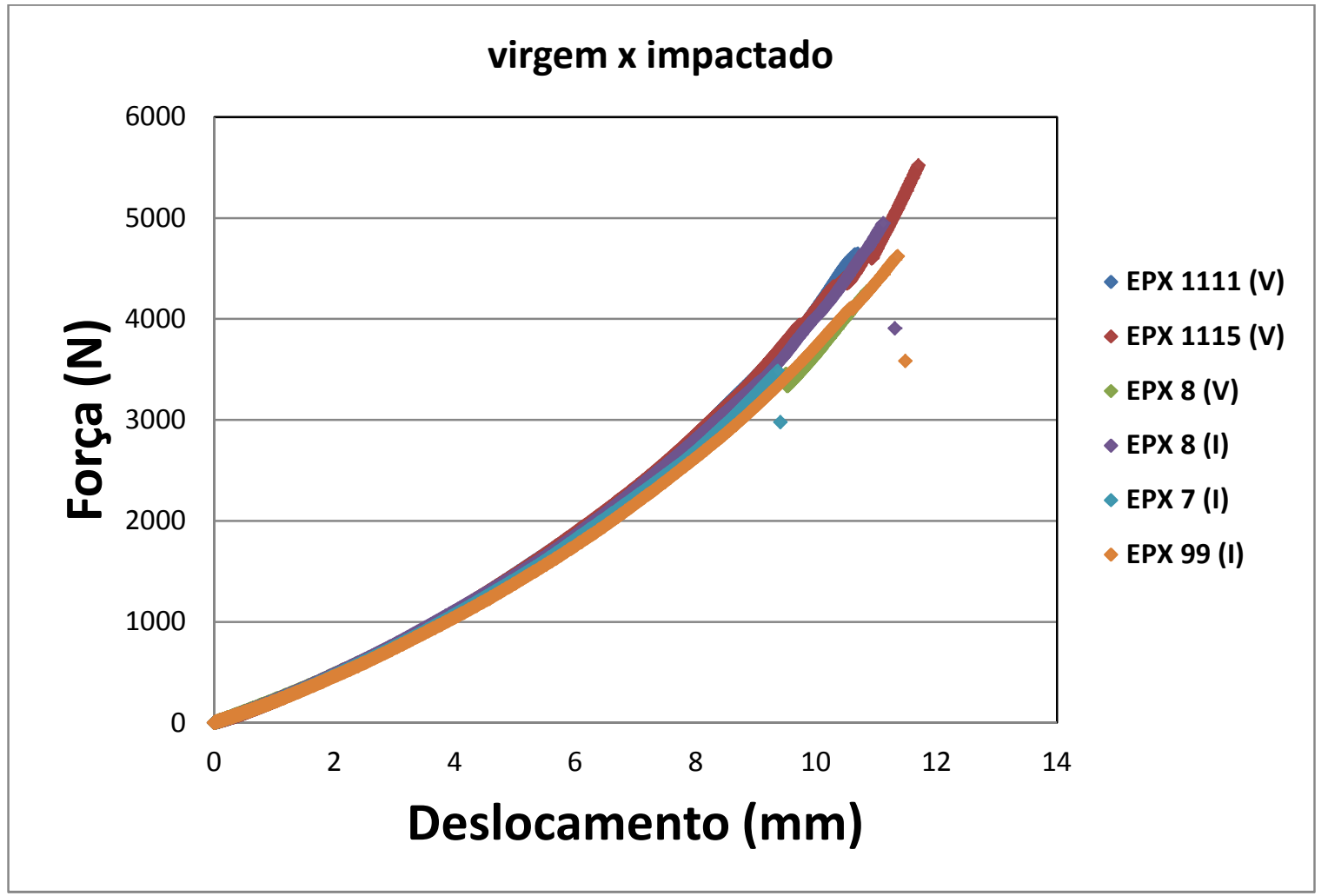

(a)

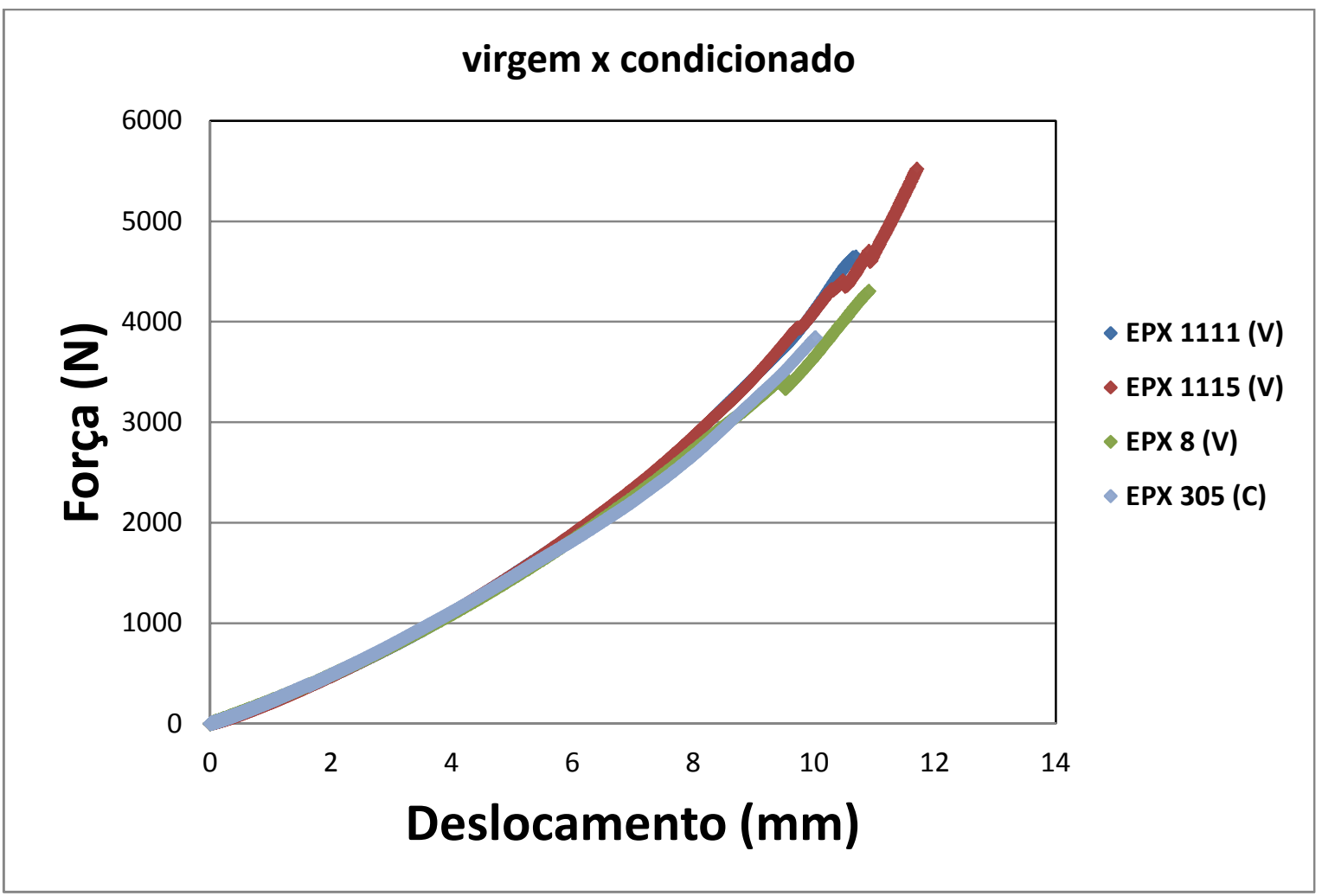

(b) 


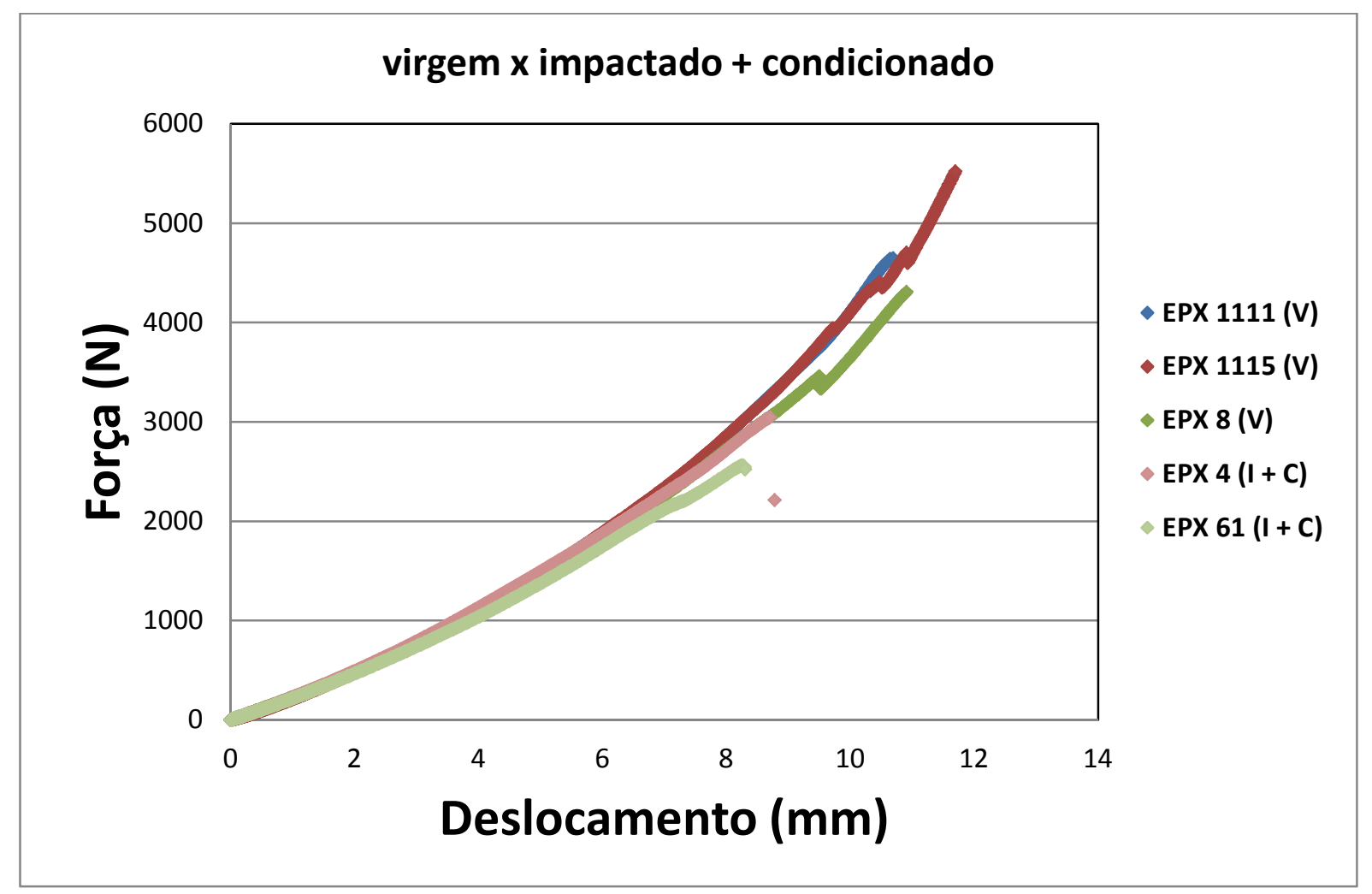

(c)

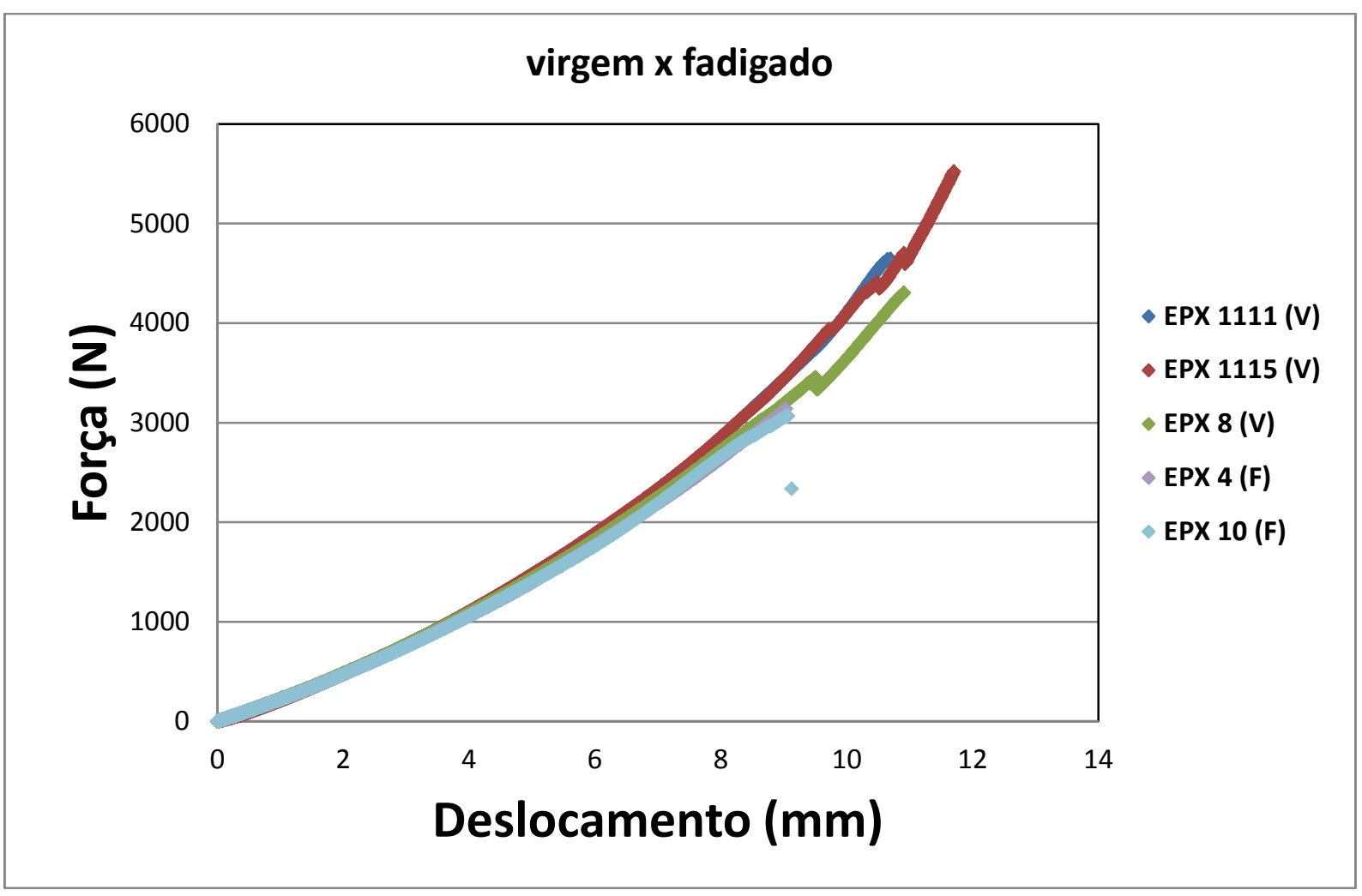

(d) 


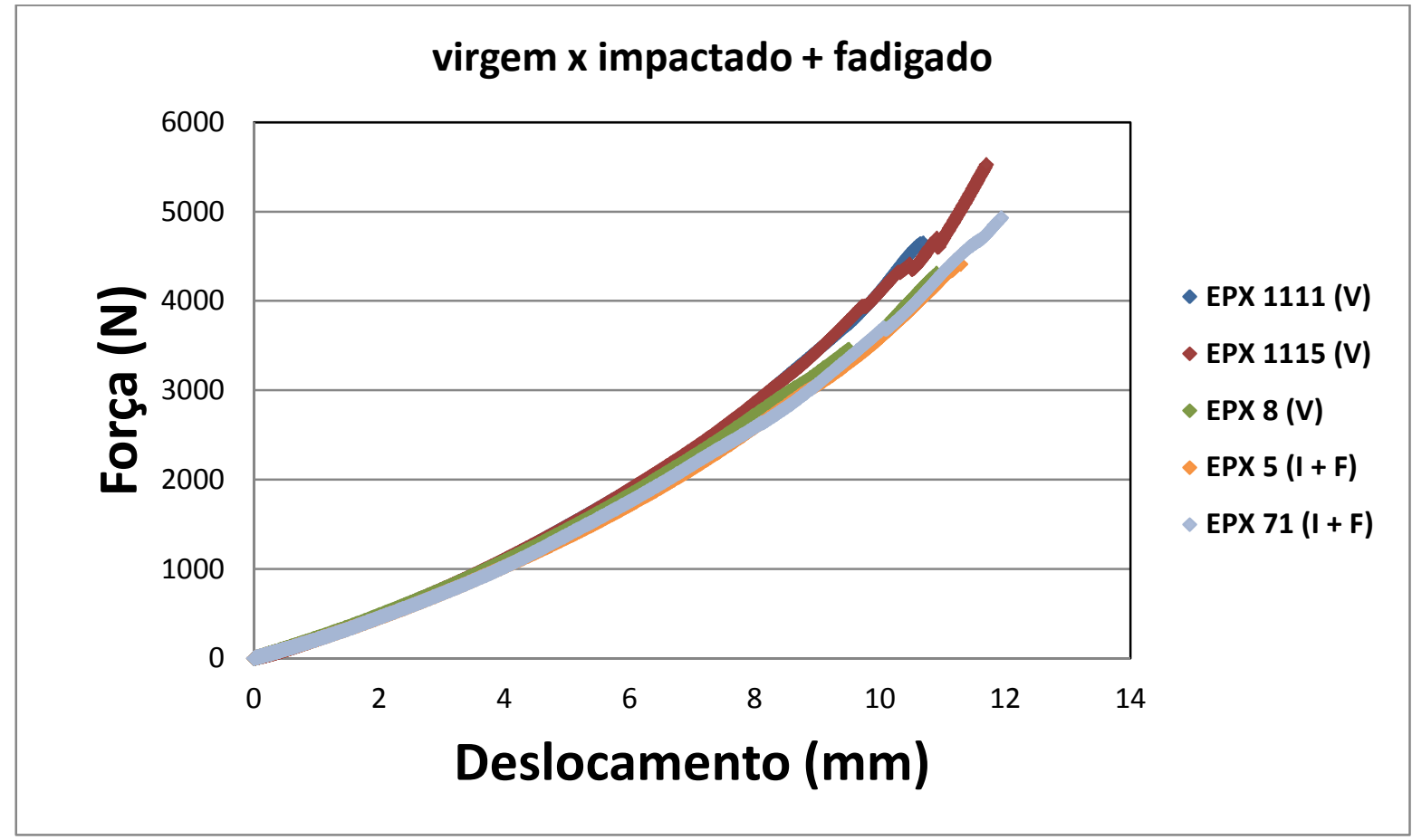

(e)

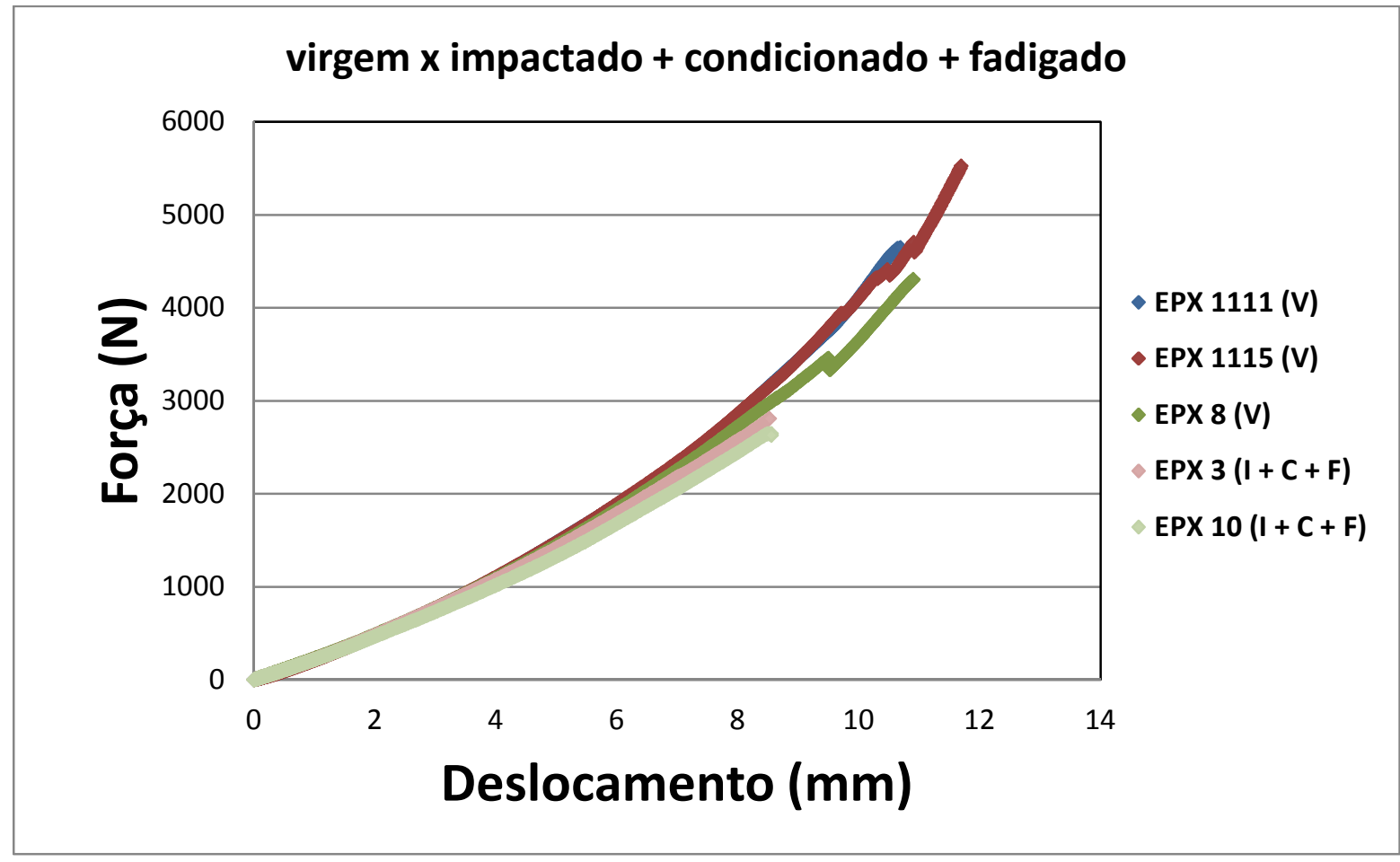

(f)

Figura B.2 - Gráficos de força x deslocamento para o EPX-C. Comparando as condições "virgem versus impactado" (a), "virgem versus condicionado" (b), "virgem versus impactado + condicionado" (c), "virgem versus fadigado" (d), "virgem versus impactado + fadigado" (e), "virgem versus impactado + condicionado + fadigado" (f). 